
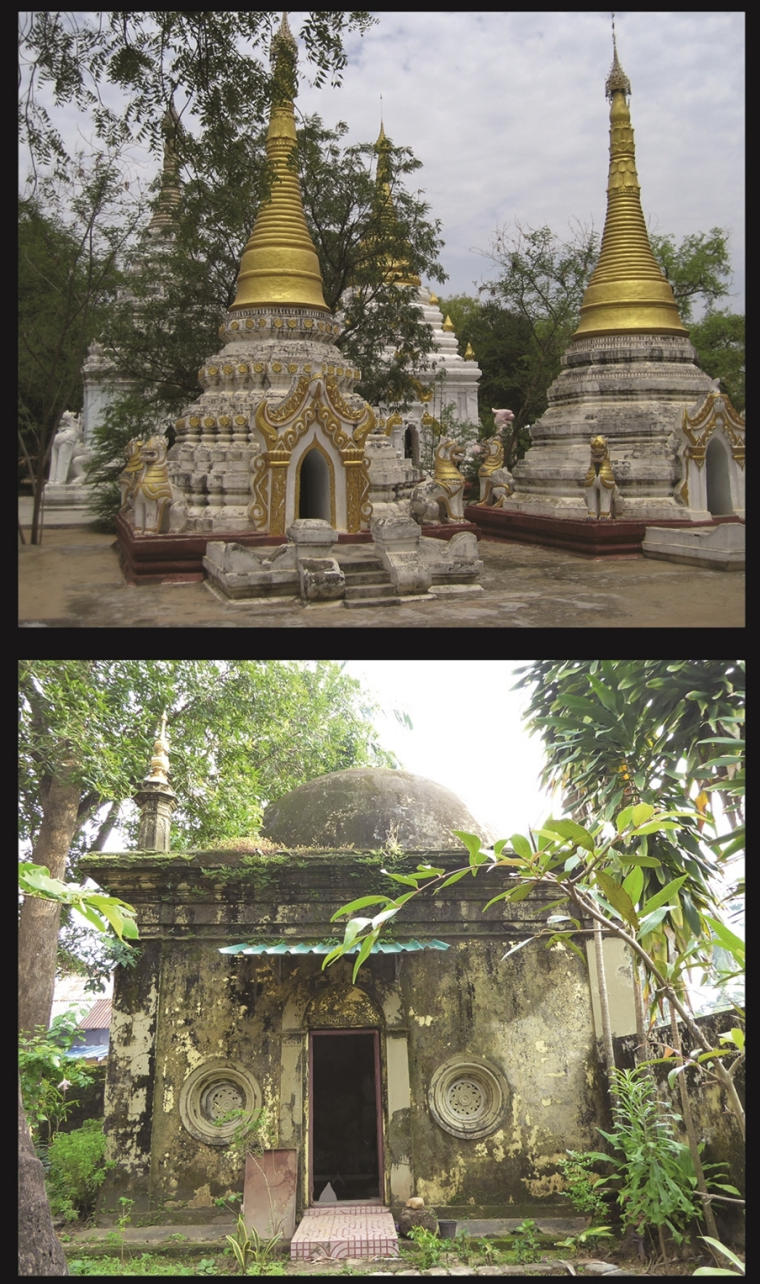

\title{
BUDDHIST AND ISLAMIC ORDERS IN SOUTHERN ASIA Comparative Perspectives
}

EDITED BY R. MICHAEL FEENER AND ANNE M. BLACKBURN 


\section{BUDDHIST AND ISLAMIC ORDERS IN SOUTHERN ASIA}





\section{BUDDHIST AND \\ ISLAMIC ORDERS IN SOUTHERN ASIA}

Comparative Perspectives

Edited by R. Michael Feener and Anne M. Blackburn

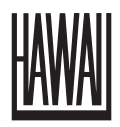

UNIVERSITY OF HAWAI'I PRESS

Honolulu 


\section{Library of Congress Cataloging-in-Publication Data}

Names: Feener, R. Michael, editor. | Blackburn, Anne M., editor

Title: Buddhist and Islamic orders in southern Asia : comparative perspectives / edited by R. Michael Feener and Anne M. Blackburn.

Description: Honolulu : University of Hawai'i Press, [2019] | Includes

bibliographical references and index.

Identifiers: LCCN 2018006253 | ISBN 9780824872113 (cloth ; alk. paper)

Subjects: LCSH: Buddhism—South Asia—History—Case studies. | Islam—South Asia—History—Case studies. | Buddhism—Southeast Asia—History—Case studies. | Islam - Southeast Asia-History-Case studies.

Classification: LCC BQ322 .B83 2019| DDC 294.3/65095-dc23

LC record available at https://lccn.loc.gov/2018006253

Cover photos: Top, Buddhist devotional monuments at Monywe, Burma (Anne Blackburn); bottom, shrine of a Sufi saint at Kozhikode, India (R. Michael Feener)

III

An electronic version of this book is freely available, thanks to the support of libraries working with Knowledge Unlatched. KU is a collaborative initiative designed to make high-quality books open access for the public good. The open-access ISBNs for this book are 9780824882419 (PDF) and 9780824882426 (EPUB). More information about the initiative and links to the open-access version can be found at www.knowledgeunlatched.org.

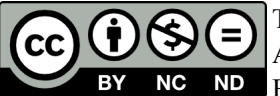

The open access version of this book is licensed under Creative Commons Attribution-NonCommercial-NoDerivatives 4.0 International (CC BY-NC-ND 4.0), which means that the work may be freely downloaded and shared for non-commercial purposes, provided credit is given to the author. Derivative works and commercial uses require permission from the publisher. For details, see https://creativecommons.org/licenses/by-nc-nd/4.0/. 


\section{CONTENTS}

Preface vii

1. Sufis and Sarigha in Motion: Toward a Comparative Study of Religious Orders and Networks in Southern Asia 1 ANNE M. BLACKBURN AND R. MICHAEL FEENER

2. A Hadramī Sufi Tradition in the Indonesian Archipelago 20 ISMAIL FAJRIE ALATAS

3. The Itineraries of "Sīhaḷa Monk" Sāralañkā: Buddhist Interactions in Eighteenth-Century Southern Asia 48 ALEXEY KIRICHENKO

4. Challenging Orders: Tarīqas and Muslim Society in Southeastern India and Laṅkā, ca. 1400-1950 75 TORSTEN TSCHACHER

5. Whose Orders? Chinese Popular God Temple Networks and the Rise of Chinese Mahāyāna Buddhist Monasteries in Southeast Asia 99 KENNETH DEAN

6. Sufi "Orders" in Southeast Asia: From Private Devotions to Social Network and Corporate Action 125 MARTIN VAN BRUINESSEN

7. Shattāaniyya Sufi Scents: The Literary World of the Surakarta Palace in Nineteenth-Century Java 153

NANCY K. FLORIDA

8. Negotiating Order in the Land of the Dragon and the Hidden Valley of Rice: Local Motives and Regional Networks in the Transmission of New "Tibetan" Buddhist Lineages in Bhutan and Sikkim 185 AMY HOLMES-TAGCHUNGDARPA

Contributors 209

Index 213 



\section{PREFACE}

Recent work on religion and society in Southern Asia has highlighted the dynamic ways in which translocal traditions move across and take root in the region's diverse cultural contexts. These broad dynamics have been of interest to historians of both Buddhism and Islam, producing work that has explored different aspects of the networks linking coreligionists across premodern Southern Asia. Despite shared academic interests, researchers working in these two distinct subfields of the history of religions have rarely engaged each other in a focused or sustained way. Although scholars of both Buddhist studies and Islamic studies share interests in similar processes and focus on contexts that overlap in terms of both periodization and geography, little has been done to share investigative approaches and methods of interpretation.

There is, however, much that scholars working in these two fields could learn from each other to support our evolving understandings of the circulation and localization of religious traditions. For example, historians of Muslim societies can benefit from recent work in Buddhist studies on aspects of material culture as well as from perspectives on dimensions of ritual practice that stretch beyond canonical literature and narrowly doctrinal definitions of the tradition. Approaches that direct attention toward the intentionality of participants in localized forms of devotion and that examine where protective and/or salvific power is attributed by practitioners can and should stimulate new thinking about the diverse modes of Muslim ritual practice in Southern Asia. Likewise, scholars of Buddhism could learn from their colleagues in Islamic studies who have been developing models of circulation and connected histories, bringing into view transregional dimensions of institutional and intellectual history. Moreover, studies of Islam in Southern Asia offer thought-provoking treatments of smaller-scale contexts of reception and localization. Working together, scholars of Islam and Buddhism can develop more nuanced and integrated analytical frameworks for conceptualizing the coproduction of polity, ritual forms, intellectual currents, and material cultures.

To facilitate such work, we must first create spaces for constructive engagement between the fields of Islamic and Buddhist studies. This volume aims to create one such space by drawing analytic perspectives developed by both fields 
into discussions of one major dimension of the history of religion in Southern Asia. The focus is on "religious orders" - conceptualized here as a comparative category for discussion of Sufi brotherhoods and Buddhist monastic and ritual lineages. Both Buddhism and Islam historically developed institutional mechanisms that facilitated the expansion and maintenance of liturgical, literary, and clerical/ritual specialist connections. These were important factors in the historical development of both traditions - particularly during the period from the sixteenth through the nineteenth centuries.

This volume brings together contributions by scholars engaged in cuttingedge work in the study of Islam and Buddhism in Southern Asia in conversation about the ways in which "orders" have functioned within these two traditions to expand and sustain transregional religious networks. Orders have presented particular traditions and their human representatives as attractive and authoritative, and have established means by which far-flung local communities could come to be recognized and engaged with as part of a broader world of coreligionists. This volume opens new spaces of creative interaction between scholars in both fields in order to develop a better understanding of the complex roles played by religious networks in the history of Southern Asia.

This book is the fruit of exchanges launched at the conference "Orders and Itineraries: Comparative Religious Networks in Southern Asia," convened on February 21 to 22, 2013, at the National University of Singapore's Asia Research Institute. We are immensely grateful for the generous support of the institute and its staff, and especially to Valerie Yeo for her outstanding work in organizing the event. We would also like to extend our thanks to all those who joined the discussions in Singapore and shared their thoughts, especially to Prasenjit Duara, Rick Weiss, Nola Cooke, Ramani Hettiarachchi, Iain Sinclair, Gerrit de Vylder, Ines Zupanov, Oona Paredes, Lim Peng Han, Carolina Dionco, Masao Imamura, and Andrea Acri. We are also grateful to Adora Elisapeta Jones for her kind assistance with copyediting and formatting the final manuscript for publication. 


\section{BUDDHIST AND ISLAMIC ORDERS IN SOUTHERN ASIA}





\title{
SUFIS AND SANंGHA IN MOTION \\ Toward a Comparative Study of Religious Orders and Networks in Southern Asia
}

\author{
ANNE M. BLACKBURN AND R. MICHAEL FEENER
}

The multidisciplinary study of transregional networks has seen remarkable growth over recent decades. Following approaches developed by Fernand Braudel in his path-breaking work on the Mediterranean world, ${ }^{1}$ scholars have developed an impressive body of work on the longue durée economic and social histories of other regions. ${ }^{2}$ Work along such lines on the complex seascapes and shorescapes connecting diverse parts of southern Asia-including the major contributions by K. N. Chaudhuri and Patricia Risso for the medieval and early modern periods as well as those by Thomas Metcalf, Sugata Bose, and Sunil Amrith for the modern - has done much to map out major dynamics of trade and state relations across the Indian Ocean. ${ }^{3}$ The work of Anthony Reid, Denys Lombard, Janet Abu-Lughod, and Roderich Ptak has added important dimensions to our understanding of the integrated histories of the eastern end of the Indian Ocean world and its connections to the South China Sea through the waters of the Indonesian archipelago. ${ }^{4}$

\section{COMPARATIVE PERSPECTIVES ON RELIGIOUS NETWORKS}

Against this background, other scholars working in diverse fields of history have sought to uncover new data and highlight its relevance for understanding varied modes of connectivity across South and Southeast Asia. ${ }^{5}$ To date, they have mined rich sources for identifying connections and tracking commodities, individuals, and ideas along complex paths crisscrossing the region. Students of the history of religions have also been active on parallel fronts in recent years, making considerable advances in mapping shifting pathways and patterns of connection along maritime and land routes that linked the members of religious communities across Asia and beyond. ${ }^{6}$ The wealth of data brought to light by 
these studies makes it clear that for centuries modes of transregional connection played an important role in shaping local communities, their patterns of religious practice, and their forms of collective identification.

At the same time, however, such richly detailed examinations of particular networks have tended toward a significant degree of specialization, mapping the transregional movement of individuals and institutions within frameworks of particular communities and diasporas. These analyses have rarely been developed in substantial communication with adjacent fields or through a comparative orientation involving more than one religious tradition. This volume demonstrates the benefit of collaboration between scholars in the fields of Islamic studies and Buddhist studies. By highlighting points of structural and chronological comparison and contrast, this comparative exercise on Buddhist and Islamic networks and institutions allows for critical reflections on the conceptual frameworks used across different fields in the comparative history of religions. As we have pursued our work in this direction during recent years, we have found our approach to comparison resonant with that elaborated in the recent work of Peter van der Veer, who argues that "comparison should be conceived not primarily in terms of comparing societies or events, or institutional arrangements across societies, although this is important, but as a reflection on our conceptual framework as well as on the history of interactions that have constituted our object of study."7 This volume as a whole demonstrates the ways in which developing robust comparison between analogous developments in Buddhist and Islamic traditions can be mutually illuminating for both fields of study.

Historians of Buddhism and of Islam can both benefit from a more substantial engagement with the work being pursued by their counterparts. Such engagement, however, requires shared awareness of the scholarly conversations within each subfield - something that we as editors have tried to develop through our collaboration on this volume. The contributions to this volume focus on one category of comparative analysis, that of religious "orders," with a geographic focus on the region of Southern Asia in which Buddhism and Islam have had a long and substantial presence. The comparative exercises collected in the volume help us to better appreciate the historical dynamics involved in the ongoing reconfiguration of Buddhist lineages and Sufi "brotherhoods." Some of these studies direct attention toward the roles of polities in patronage of religious networks and their localization in specific settings, revealing patterns shared across Islamic and Buddhist contexts. Others point the way toward a comparatively informed periodization of changes in the character of orders and their relationship to wider communities within the traditions of Islam and Buddhism. Moreover, by developing exemplary cases from three different Buddhist "subtraditions," oriented respectively toward authoritative texts in Classical Chinese, Classical Tibetan, and Pali, and characterized by strikingly different institutional arrangements, this volume underscores the fruitfulness of intra-Buddhist comparison across thematic axes. All chapters draw attention 
to the fact that networked persons in both traditions were not always strongly institutionalized; members of Buddhist lineages and Islamic turuq often moved through the Southern Asian region and developed local bases without being involved in complex corporate organizations.

\section{ON "ORDERS" WITHIN AND ACROSS TRADITIONS}

The terminology of religious orders, derived from Christian religious traditions, has been deployed within the academic study of religion to identify forms of association among religious specialists across diverse traditions. These lines of scholarly discussion are situated within a long legacy of scholarship in which Christian traditions have provided not only foundational categories, but also implicit bases for comparison in the academic study of religion. This volume deliberately attempts to develop a different kind of comparative exercise, working across two non-Christian traditions-Islam and Buddhism-while paying close attention to the diverse and historically contingent forms of institutionalized association in which religious specialists participated.

The idea of orders has been central to discussion of Islam and its diverse traditions of Sufi lineage. Although the term "Sufism" has been used by modern scholars with reference to things ranging from metaphysics and poetry to ritual practice and technologies of invulnerability, discussion of Sufi orders focuses more specifically on mechanisms for the transmission of teachings in a lineage associated with a particular "master" (Arabic shaykh; Persian pir). The Arabic term frequently translated as "order" or "brotherhood" here, tarīqa (pl. țuruq), might more literally be rendered as "path" or "way." By the twelfth century, however, it had emerged as a technical term for more formalized lineages of authority, often identified posthumously with an eponymous founder. ${ }^{8}$ Mark Sedgwick has cautioned against assumptions about institutional continuity that Christian models of religious orders might encourage when looking comparatively at other traditions. In particular, he highlights the extent to which Sufi orders have historically remade themselves in diverse forms through cyclical dynamics of disruption and stabilization. ${ }^{9}$ This dynamic history of internal Sufi reconfigurations complicates simplistic comparisons with more institutionalized forms of Christian monasticism.

The institutional dimensions of Sufi orders have nevertheless sometimes been overplayed in modern scholarship on the early history of Sufism. As Nile Green has recently argued against such overdetermined images of orders, "while some aspects of these mechanisms were organizational and corporate in the sense that the term brotherhood usually suggests, they were both enabled by and subject to the intangible but ultimately more weighty operations of tradition as a conceptual and symbolic mechanism. We should not then expect the brotherhoods ... [of the early period] to comprise complex organizations with card-carrying members and efficient managerial hierarchies."10 
Indeed, more fluid structures for the transmission of Sufi traditions have proved remarkably resilient as mechanisms for connecting Muslims across both time and space. Marshall Hodgson powerfully highlighted the importance of Sufi orders (alongside the mechanisms of Islamic legal scholarship) as one of the primary means by which a rapidly expanding Islamic world maintained a degree of integration despite the political fragmentation of the post-Abbasid period..$^{11}$ More recently, an increasing number of scholars have expanded on the importance of turuq in the formation of networks linking far-flung regions of the Muslim world from West Africa to Southeast Asia. For example, in an essay on "transregional interactions," John Voll, drawing on the terminology of Christopher Bayly, has discussed Sufi orders as a prime example of "archaic globalizers." 12 Neither of these two authors, however, went into great detail on exactly how turuq actually functioned in this capacity or attempted to situate these aspects of Sufi orders in comparison to contemporaneous formations of religious networks within other traditions.

Scholars of Buddhism have likewise devoted attention to associational groups involved in the internal differentiation and expansion of the tradition. Foundational works on Buddhist history made explicit use of the term "order" to refer to the Buddhist monastic community (sangha), revealing an implicit conceptual debt to studies of Christianity among an early generation of scholars. ${ }^{13}$ Over the course of the twentieth century, a variety of other terms came into use among scholars of Buddhism. The terms used to refer to more narrowly delineated associational groups of textual and ritual specialists - who may be monastic or nonmonastic —include "order," "fraternity," "school," "sect," and "lineage."14 Such terms figure in scholarly accounts of the historical and geographic expansion of Buddhism across Asia, with emphasis on the role played by textual and ritual specialists in channeling selected philosophical/doctrinal positions, textual corpora, and potent ritual practices across the region-often in symbiotic relationships with commercial, military, and administrative elites. ${ }^{15}$

Across its diverse usages within Buddhist and Islamic studies, the concept of an "order" has encompassed a range of broadly shared features identified among many scholars working within these distinct subfields of the academic study of religion. Prominent among these features are conceptions of lineage or genealogy. In the case of Islam, the Sufi tarīqa, structured according to a lineage of religious authority (Ar. silsila) comprises one of a number of forms of defining tradition grounded in the teachings of the Prophet. Sufi genealogies structured according to silsila and the Sufi orders (Ar. turuq) that came to be built around them developed alongside other, parallel mechanisms for the transmission of tradition, including those of hadìth scholarship focused on "chains of transmission" (Ar. isnād, pl. asānid) and the established schools (Ar. madhhab, pl. madhāhib) of Islamic jurisprudence.

There are likewise plural conceptions of lineage within Buddhist traditions. Buddhist textual and ritual specialists identify themselves and are identified 
by others in relation to both ordination lines and bonds of teacher-student relationships, including links formed through the transmission of specific ritual (including meditation) techniques. Buddhist monastics (both male and female) undergo an ordination ritual that emplots the ordinand within Buddhist institutional and associational space. The ritual location of ordination itself indicates the ordinand's participation within a distinctive subsector of the Buddhist monastic establishment within a particular polity or geographic region, usually one to which the ordinand has gained access through his or her primary teacher. The ordinand is also understood to stand within a lineage relationship to the preceptor (upajjhāya/upajjhāyā), who presents the candidate for ordination. Historically, it was common for Buddhist monastics to study with multiple teachers, before and subsequent to their ordination. Teachers and students could thus report their place within their lineages in a number of ways, providing an extremely flexible means of expressing intellectual and material inheritance, loyalty, and other bonds.

The breadth and flexibility of such teacher-student bonds and lineage claims characterized nonmonastic teacher-student networks as well. Especially in the Himalayan and Central Asian worlds of Vajrayāna Buddhism, but also elsewhere in Asia, nonmonastic textual and ritual specialists typically studied and forged ritual bonds with more than one teacher, generating a broad and flexible web of lineage relationships as well as nested forms of collective identification. In relation to the transregional mobilities examined within this volume, it is important to recognize that the claim to - and recognition of - participation within a shared Buddhist lineage could facilitate (often in very practical material ways) the movement of Buddhists across geographic space. For instance, lineage claims (and sometimes documents affirming them) were shaped by the acceptance of Buddhist travelers within new geographic and Buddhist institutional domains as well as the success of diplomatic projects originating from state centers. Where Buddhists competed with one another for recognition, social authority, and material well-being, especially at geographic frontiers and/ or in rapidly changing political environments, the ability to be recognized as a participant within a well-recognized, historically venerable Buddhist lineage could be central to success. As Amy Holmes-Tagchungdharpa's chapter shows powerfully, many factors contributed to such recognition.

Those connected to such lineages are also distinguished by particular patterns of practice and aesthetic markers that are constitutive signs of belonging within these genealogical traditions. For example, Buddhist ritual and textual specialists are often distinguished from one another visually by vestment practices, according to which ordination and other forms of teacher-student lineages are identified through patterns of robe wearing, and the use of sartorial accessories. Indeed, competition among Buddhist textual and ritual specialists both monastic and nonmonastic_- has often been expressed centrally through a discourse linking ways of dressing to hierarchies of purity and authority. In 
such contexts, disputes over appropriate dress are closely linked to an evaluation of specialists' comportment and their right to occupy positions within eminent and powerful Buddhist institutional establishments. ${ }^{16}$ Although historically members of some Sufi orders have sometimes been distinguished by particular styles and colors of robes and headdress, such visual markers of adherence to a particular lineage have been relatively less pronounced in Islamic traditions. Rather, attachment to different orders has tended to be most clearly marked in the performance of specific forms of ritual practice, such as in preferences for particular forms of vocal or silent performance of the ritual remembrance of God (dhikr) or the recitation of particular litanies..$^{17}$

Perhaps the most obvious point of comparison between Islamic and Buddhist orders - and one of central concern within this volume-is their role in the creation and maintenance of transregional networks. As noted earlier, scholars of Buddhism and Islam have devoted considerable attention to the relationship between orders and the geographic expansion of Islam and Buddhism across Southern Asia and beyond. Although in both scholarly traditions such geographic extension was initially treated without much nuance, recent work in both fields has begun to critically examine the chronology of the expansion of orders and their members across the Asian region and to develop more finegrained pictures of the dynamics of localization involved in such expansionary processes, including what Holmes-Tagchungdharpa here calls "technologies of transmission." Scholars of Buddhism have begun to investigate in more detail how Buddhist ideas, institutions, and forms of practice were localized within particular arenas of Southern Asia. These investigations have drawn attention to the fact that the transregional extension of Buddhism in Asia should be understood as a multidirectional networked process rather than a unilinear extension of Indic Buddhism.

In this regard, Prapod Assavavirulhakorn draws attention to the historical complexity that characterized the extension of Buddhism beyond India:

The introduction of Buddhism [to Southeast Asia] did not occur in a single moment, nor as a single act, but during a long process of time. . . It is likely that there was more than simply one introduction, but rather, multiple introductions. And, there was not the introduction of just one single kind of Buddhism, but of numerous schools of Buddhism. This fact, together with the extensive area exposed to Indian cultures to which Buddhism belongs, makes the issue even more complicated, because this allows for the possibility that different places were exposed to different types of Buddhism at the same time. And it is probable that some regions did not adopt Buddhism directly from India. ${ }^{18}$

In addition to emphasizing that Buddhism and Buddhist orders extended their reach in the Southern Asian region through long and historically complex 
processes characterized by multiple locations of origin, it must be noted that contingent local circumstances also shaped the reception and patronage of members of Buddhist orders within new territories. These histories require much more detailed research than they have tended to receive. ${ }^{19}$ As the work of Alexey Kirichenko in this volume suggests, it may be fruitful to conceptualize the expansion of religious orders as occurring on a spectrum of institutionalization. At the extreme end of deinstitutionalization we find sporadic transmission of objects, texts, ordinations, and so on, moving separately from the circulation of lineages and their specialists. The opposite pole is characterized by the substantial expansion and localization of lineages along with distinctive practices and corporate institutional forms. Kenneth Dean, in his chapter on Chinese networks in Malaya, refers to these as "formal religious orders." Perhaps more common than scholars have realized, but well attested by this volume, was the circulation of lineages separately from complex corporate institutions. Such lineages offered forms of collective identification and aspirations to practice that could be flexibly deployed in diverse local contexts, compatible with existing local practices and social and institutional dynamics.

At the same time, historians of Islam have come to substantially revise previously dominant narratives of the spread of Islam in Southern Asia. Recent scholarship on the history of Islam in the Indonesian archipelago, for example, has been marked by the development of increasingly nuanced and contextualized views on the roles Sufi orders played in processes of Muslim expansion during the premodern period. ${ }^{20}$ Michael Laffan has sounded a strong cautionary note in the face of the paucity of evidence that we actually have for organized taríqa activity during the earliest phases of the Islamization of the Indonesian archipelago. Moreover, even after affiliation to particular orders appears more prominently in the seventeenth century, this appears in connection with elite court circles rather than as mechanisms for the spread of Islam among the broader population. ${ }^{21}$ Such close connections between Sufism and the structures of empire were to remain important in several parts of Southern Asia over the centuries that followed. ${ }^{22}$ What is clear through all this is that, in the premodern history of Islam in Southern Asia, Sufi orders functioned not primarily as expansionary beachheads, but rather as contextualized loci that helped to redefine modes of belief and practice for religious elites under state patronage.

Several of the contributions to this volume pursue particulars of how certain orders took shape in Southern Asia over the course of the nineteenth century. Torsten Tschacher, for example, presents an insightful perspective on the ways in which two Sufi traditions, the Qādiriyya and the Shādhiliyya, developed in southern India and Lankā in interaction with broader reconfigurations of orders across the Indian Ocean world during that period. In his contribution to this volume, Martin van Bruinessen critically explores the development of more popular forms of localized tarekat affiliation through his examination of the formation of confessional communities centered on rural Islamic 
schools and devotional communities in Java and Sumatra. His chapter highlights how "corporate" forms of Sufi traditions appear in Indonesia only from the nineteenth century, a period in which other types of Muslim communities that might be viewed as "orderlike formations" were also emerging. The work of Kenneth Dean similarly directs attention to the historically late monasticization of Chinese Buddhist associations within the region, shaped by British colonial policies in Malaya as well as new intellectual and institutional directions taken by Buddhists on the southern Chinese mainland. These affected Southern Asia through South China Sea Buddhist networks. ${ }^{23}$

\section{SOUTHERN ASIA}

In order to delimit the scope of our comparative exercise, this volume is organized around a regional focus on "Southern Asia." This region-stretching from India, Sri Lanka, and the Himalayas through mainland Southeast Asia and across the Indonesian archipelago — has long been a site of dynamic and overlapping interaction between Buddhist and Muslim communities in motion. It thus forms a unit of analysis that is not only geographically contiguous, but also marked by a historically high degree of economic and cultural integration. The mobile persons and communities investigated in the chapters that follow understood themselves to function within a broad transregional geography that transcends the boundaries of modern academic area studies frameworks of "South Asia" and "Southeast Asia."

Similarities in the ways in which both Buddhism and Islam were localized within this Southern Asian region stem in part from long centuries of interaction between these two traditions, although this interactive history requires much further scholarly investigation than it has received to date. ${ }^{24}$ Buddhists and Muslims, with their own various lineages and institutions, acculturated themselves in recognizably similar ways to a shared regional landscape characterized by deep historical dynamics of circulation. This regional landscape was constituted by patterns of political formation and the employment of supramundane power within human territory that extended in similar ways across Southern Asia. Buddhism and Islam underwent comparable processes of deep regional localization, and within both traditions the members of orders played significant roles in these processes. There are also substantial similarities in the dynamics through which orders were localized in Southern Asia in close relationship to regional polities.

This volume builds on our own previous work toward conceptualizing new approaches to religious connections across Southern Asia. Michael Feener has argued elsewhere for the importance of looking beyond established paradigms of "Indianization" and "influence" between "South" and "Southeast" Asia in order to better recognize the interconnected processes of social transformation that animated the connected histories of Islamization across this broader region. ${ }^{25}$ 
Anne Blackburn's study of eighteenth- and nineteenth-century transregional Buddhist projects involving Lañkā underscores the deeply connected monastic itineraries and imaginations of Buddhist community negotiated by Southern Asian monks across the boundaries of present-day South and Southeast Asia, often exceeding national and protonational geographic limits. ${ }^{26}$ Such work serves to highlight the extent to which Cold War-era area studies optics can impede, as much (if not more) as they may facilitate, understandings of interactions between societies of "South Asia" and "Southeast Asia" in earlier periods.

Across this broader geography, local religious specialists within orders of both traditions remained in constant communication for centuries through dynamic circulations of people, ideas, texts, objects, and practices. As we see especially in the chapters by Dean, van Bruinessen, and Alatas, circulations brought diverse currents of internal reform and notions of ritual and lineage purity to the Southern Asian region from distant locations, and these moved across Southern Asia with considerable speed. At the same time, distinctive reconfigurations within the region could produce reverberations across networks of Buddhist and Islamic orders and the broader religious traditions of which they were part. Read together, the chapters in this volume draw attention to similarities across Islam and Buddhism - both within and beyond Southern Asia - in the ways that orders were shaped and reshaped through transregional processes under way within their respective traditions. In addition, they allow us to specify more closely significant points of chronological convergence between the formative dynamics of orders in both traditions, with changes in the forms of institutional structures as well as in the ideological conception of community defined in relation to particular orders. As the ensuing chapters demonstrate, comparative examinations of religious orders in Southern Asia must take into account the deep and continuing history of increasingly rapid and intense communication and mobility across the wider Buddhist and Muslim worlds, as well as the contemporaneous production of new forms of religious practice and authority at multiple points within changing religious networks during the nineteenth and twentieth centuries.

\section{NETWORKS IN HISTORY}

Scholars of Islam have yet to address fully the challenge poignantly proposed by Carl Ernst and Bruce Lawrence more than a decade ago to "figure out how to understand ... [Sufi orders] as historical developments." 27 There is thus a clear need for the continuing development of more dynamic, diachronic approaches to understanding the shifting forms and features of Islamic religious orders across diverse contexts. Scholars of Sufism continue to struggle with considerable historiographic problems. Devin DeWeese has insightfully identified two aspects of the challenges faced here: "both because we know so little of the actual role of Sufis in Islamization, and because our image of Sufis themselves 
has been shaped by later textual sources." 28 This is a powerful reminder of our need to develop more nuanced readings of the literary texts of the Sufi traditions in historical context.

Nancy Florida pursues such work in her contribution to this volume on vernacular Sufi traditions of the Shatțāriya order in nineteenth-century Java. Her discussion of this textual tradition demonstrates the continued association of certain forms of Sufism with court culture in the nineteenth century even as the new political realities of European imperialism reconfigured the nature of the sultanate. Through her close, historically contextualized reading of a Javanese Sufi poem (suluk), Florida reveals the complex nature of both distinctly local aesthetics and connections to a transregional discursive tradition in the conceptualization of a Sufi order. In her presentation of the history of the tarekat within courtly circles of the Surakarta palace, she explores the ways in which the literary lineages defining the order navigated both colonial reconfigurations of political power and internal movements of Islamic reform over a tumultuous period of its history. Florida's work thus provides a compelling case for the continuing importance of particular lines of Shațāāi textual tradition even during a period in which — as Martin van Bruinessen highlights in his chapter — at more popular levels the teachings of that order had become more "diffused" through folk cosmologies and practices of magic.

Other chapters in this volume further develop new approaches to the historical configurations of turuq in the nineteenth century. As Ismail Alatas demonstrates with regard to the 'Alawiyya in the Netherlands Indies, the period saw an increased emphasis on standardization in conceptions of Islamic orthopraxy among some Sufi orders. Focusing on the career of 'Abdallāh b. 'Umar ibn Yahyā (d. 1849), he explores the microhistorical interactions between this itinerant Sufi scholar, Dutch colonial authorities, and local royal houses. His work highlights the material infrastructure and contingent historical circumstances that informed the reconfiguration of a particular religious order within a single tradition.

Over two decades ago, Frank Reynolds and Charles Hallisey proposed an approach to a large-scale periodization of Buddhist history. This was an invitation to bring greater diachronic precision to the study of Buddhism in Southern Asia and beyond and to do so through an examination of changing interrelationships among polities, Buddhist orders, ritual practice, textual forms, and languages. ${ }^{29}$ A striking feature of this work was its early attempt to recognize and analyze historical changes in Buddhist conceptions of the geographic space that constituted a perceived Buddhist world as well as ways in which Buddhist communities were understood by their members to map onto cultural, national, and other political geographies. ${ }^{30}$

However, the conceptual naturalness of contemporary nation-state boundaries has exerted a powerful force within the field, making it difficult for scholars of Buddhism to recognize Buddhist socio-institutional projects occurring 
at scales larger and smaller than that of the nation. At the same time, the rich philological and philosophical orientation that characterized several generations of scholarship on Buddhism in Southern Asia has often abetted - if not always intentionally - a tendency to examine textual/doctrinal developments separately from institutional contexts. ${ }^{31}$ Thus, despite an important call to consider the transregional collective constituted by shared participation in a particular Buddhist textual-conceptual system such as the "Pāli imaginaire,"32 the study of premodern and precolonial Buddhist orders and the networks related to them has proceeded somewhat slowly, ${ }^{33}$ and sometimes with too great a reliance on the narratives of monastic "missions" articulated by Buddhist texts themselves. ${ }^{34}$ Studies of the Himalayan-Tibetan world have offered a valuable corrective to this, with considerable comparative potential for other parts of Southern Asia. ${ }^{35}$ Moreover, inspired partly by the expanding field of Indian Ocean studies as well as by an explosion of data from the "Silk Road" connecting central, southern, and eastern Asia, other recent scholarship attends more closely to the ways in which Buddhist institutions and the members of Buddhist orders participated within and helped to shape the transregional ecosystems of Southern Asia. ${ }^{36}$

As in studies of Sufism, understanding the history of Buddhist orders requires more work to clarify how specific Buddhists operated within particular frameworks of organization and action. One significant challenge faced by scholars working along such lines is that of negotiating literary portrayals of orders and their individuals that often obscure historical contexts and conditions. Alexey Kirichenko's chapter in this volume points out new types of textual evidence, including that emanating from royal and monastic bureaucracies, that may be explored fruitfully in order to reconstruct the lives and itineraries of mobile Buddhists who participated in one or more orders within the Southern Asian region. In addition, Kirichenko develops a diachronic and intertextual strategy that can be used to reveal how members of orders negotiated their movement across institutional boundaries and secured patronage and authority in diverse locations, while accommodating themselves to historically and geographically shifting expectations of specialist behavior and experience. His study of Sāralanka's (b. ca. 1730) movement between rapidly shifting political formations in Ayutthaya, Tenasserim, and Ava-like Ismail Alatas' on the Sufi shaykh Ibn Yahyā in his chapter-helps us to appreciate the role of highly mobile individuals in the creation, maintenance, and transformations of orders through their negotiation of diverse social, political, and economic relationships.

Beyond court circles, orders were also reconfigured in relation to patterns of religious patronage by merchant communities in several parts of Southern Asia during the eighteenth and nineteenth centuries. In his contribution to this volume, Torsten Tschacher calls attention to the ways in which the organization of Sufi networks and lineages shifted over the course of the eighteenth century with new dynamics of support and sponsorship taking hold among merchant elites in the Tamil regions of India and Lankā. The type of order that 
characterized this period, however, was not one of institutionalized structures of lineage (silsila), but rather of ritual complexes associated with shrines and the communities that supported them. As Tschacher points out, more institutionalized forms of Sufism appear there only in the nineteenth century with new dynamics of consolidation arising out of encounters and entanglements between the Qādiriyya and the Shādhiliyya orders. The resonance and attraction of the kinds of Sufi reform promoted by these two orders in the nineteenth century contributed to significant transformations in conceptions of transregional networks across the far-flung coasts of the Indian Ocean. ${ }^{37}$

\section{COLONIAL MODERNITY AND THE FURTHER REMAKING OF RELIGIOUS ORDERS}

The studies produced for this volume highlight important shifts in conceptions of what constitutes a religious order in diverse but interconnected locations across Southern Asia over the past three centuries. The eighteenth and nineteenth centuries were characterized by a number of significant developments across the religious networks of both traditions in Southern Asia. As the nineteenth century progressed, new dynamics were introduced into the ongoing reconfiguration of religious orders across Southern Asia and beyond. The context was powerfully shaped by the expansion and consolidation of European imperial power along the coasts of the Indian Ocean as well as within the IndoTibetan highlands. As colonial authorities expanded their power across the region in the early nineteenth century, however, the expansion of both Buddhist and Islamic religious orders accelerated apace - with both the development of new orders in the region and the introduction of others from elsewhere. ${ }^{38}$

Encounters between religious orders and colonial officials were by no means universally antagonistic during this period. Indeed, colonial policies sometimes created (albeit often inadvertently) conditions conducive to the expansion and/ or restructuring of religious orders in the region. In the Himalayan sphere, as Holmes-Tagchungdarpa's chapter on Sikkim and Bhutan demonstrates, British interruption of earlier Sikkimese practices of royal-lama patronage opened that kingdom to a wider range of Buddhist teaching lineages. As Dean's contribution reveals, southern Chinese Buddhist orders in the Straits Settlements became more prominent in the later nineteenth century when increasing colonial pressure on Triads encouraged Buddhist entrepreneurs and other commercial elites in the region to transfer patronage from Triad-linked temples dedicated to regional deities of diverse migrant communities and clan associations to emerging Buddhist monastic establishments. Although monastic Buddhism has a long history on the Chinese mainland, distinctive patterns of overseas Chinese commercial expansion into the Straits Settlements initially favored nonmonastic Buddhist institutions - a phenomenon encouraged by the fact that what became Malaya had no prior history of royal support for Buddhist orders. The case 
presented by Dean here also reveals how the local forms taken by orders-and the practices they encouraged - were both shaped by and constitutive of changes of emphasis within the wider religious tradition. The Mahāyāna Buddhist monasteries that developed in places like Singapore, Penang, and Malacca owed much to southern Chinese reformist trajectories favoring monastic forms of Buddhist institutional life. They also helped to naturalize this new emphasis through the circulation of Buddhist teachers and discourses within the Southern Asian and southern Chinese regions.

The colonial period interplay among rapidly changing economies, polities, institutional forms, and conceptions of "religion," as well as discourses circulating within specific religious traditions, contributed to the emergence of a more formal sense of institutionalization and more bounded forms of organization and administration among orders in Islam and Buddhism. An important factor in such developments was an interconnected set of innovations within transportation and communications technologies. These allowed religious orders to explore new modes of connectivity over the second half of the nineteenth century. ${ }^{39}$ Steam-driven transport over rail and sea facilitated not only the itineraries of monks, shaykhs, and other ritual specialists across Southern Asia, but also opened up possibilities for new forms of mass pilgrimage to shrines and other religious sites. ${ }^{40}$ The rapid proliferation of print technology during this same period also had diverse impacts on the understandings and experiences of religion for many Muslims, Buddhists, and others all across Southern Asia. Indeed, such impacts were felt even in parts of the region that were not brought under full colonial administrative control, such as Thailand and Himalayan kingdoms like Tibet and Bhutan. ${ }^{41}$ Holmes-Tagchungdarpa's contribution to this volume exemplifies how colonial period expansions of infrastructure created new conditions of possibility for the development of Buddhist orders, even outside domains governed completely by colonial authorities. As her research shows, the new royal line installed in Bhutan with British support became an avid patron of the Buddhist Tantric order of Shakya Shri, originating from eastern Tibet. Bhutanese royal knowledge and patronage of Shakya Shri's order was facilitated by the expanding infrastructure for travel and print communication in the Himalayan region and across Southern Asia, helping to distinguish the new Wangchuck dynasty from its Zhabdrung predecessor. The chapters gathered here begin to suggest that the changing ecosystems of lineages, orders, and royal patronage found in Himalayan states during the British colonial period offer ground for fruitful comparison with the sultanates and princely states of India, Malaya, and the Dutch East Indies.

\section{ORDERS, PATRONS, AND AUDIENCES}

In the Himalayas, as in other parts of Southern Asia, the late nineteenth and early twentieth centuries were marked by an expansion of religious orders within 
both Buddhism and Islam. Contributions to this volume reveal that in both traditions religious orders developed widening social bases in the nineteenth and early twentieth centuries. In the process, broader segments of some communities developed ideological investments in the structures of lineage and the forms of practice that were associated with particular orders. The chapters that follow explore this expansion of patronage patterns for Islamic and Buddhist orders. In many parts of Southern Asia, royal houses continued to play significant roles in the patronage of orders. However, changes in political formations and communications technologies as well as the collective norms guiding reflections on an individual's obligations vis-à-vis his or her religious tradition all contributed to widening engagement of Buddhists and Muslims in the institutional spaces of religious orders - either as participating members, or as observers evaluating the public profiles and activities of particular orders in their communities.

Thus, in both the Buddhist and the Islamic contexts, the sense of community with a stake in orders, their definition, and their claims to authority grew significantly over the course of the nineteenth and twentieth centuries. Comparative investigation and analysis illuminates the broader ecology of religious organization that informed discrete developments within different confessional communities. This volume as a whole demonstrates that careful specialist examinations of the microdynamics of institutional expansion, sponsorship, devotionalism, and competition can be successfully placed in critical, comparative perspective. Identifying analogous processes in play across both traditions facilitates new understandings of processes of transmission, reception, and localization. It also brings into sharper relief internal reconfigurations of religious institutions and the changing relationships between orders and particular forms of patronage and power. Thus, the contributions to this volume not only provide empirically rich studies of particular religious orders in the history of Southern Asia, but also clearly attest to the benefit gained through more sustained engagement between scholars of Buddhism and Islam. Controlled comparison across religious traditions in this volume has been achieved through three phases of analysis. First, we identified zones of apparent commonality within textual and institutional practice as well as in historical circumstance, searching for cases across the contexts of Islam and Buddhism that appear to bear some family resemblance to one another. A second phase involved the detailed investigation and contextualization of each case identified within the initial comparative field, seeking a more nuanced understanding of these contexts and a sharper analysis of the processes under way within them. Finally, this introduction and the chapters that follow have drawn on the data and interpretations emerging from the second phase to propose a more refined framework of comparison for further investigation within and across traditions. We hope that this work will inspire further comparative exercises of this type, sharpening our understanding of other eras and dimensions of the historical development of these expansive and dynamic religious traditions. ${ }^{42}$ 


\section{NOTES}

1. Fernand Braudel, The Mediterranean and the Mediterranean World in the Age of Philip II (Berkeley: University of California Press, 1995). The original French edition appeared in 1949, but the work did not appear in English translation until 1972.

2. For a critical overview of such work on the "Atlantic World," see Michael A. McDonnell, "Paths Not Yet Taken, Voices Not Yet Heard: Rethinking Atlantic History," in Connected Worlds: History in Transnational Perspective, edited by Ann Curthoys and Marilyn Lake (Canberra: ANU E Press, 2005), pp. 45-62.

3. K. N. Chaudhuri, Trade and Civilisation in the Indian Ocean: An Economic History from the Rise of Islam to 1750 (Cambridge, UK: Cambridge University Press, 1985); Patricia A. Risso, Merchants and Faith: Muslim Commerce and Culture in the Indian Ocean (Boulder: Westview Press, 1995); Thomas Metcalf, Imperial Connections: India and the Indian Ocean Arena, 1860-1920 (Berkeley: University of California Press, 2007); Sugata Bose, A Hundred Horizons: The Indian Ocean in the Age of Global Empire (Cambridge, MA: Harvard University Press, 2009); Sunil S. Amrith, Crossing the Bay of Bengal: The Furies of Nature and the Fortunes of Migrants (Cambridge, MA: Harvard University Press, 2013).

4. Anthony Reid, Southeast Asia in the Age of Commerce, 1450-1680, vol. 1: The Lands Below the Winds (New Haven: Yale University Press, 1988); Anthony Reid, Southeast Asia in the Age of Commerce, 1450-1680, vol. 2: Expansion and Crisis (New Haven: Yale University Press, 1993); Denys Lombard, Le Carrefour Javanais: Essai d'histoire globale, 3 vols. (Paris: Éditions de l'École des hautes études en sciences sociales, 1990); Janet L. AbuLughod, Before European Hegemony: The World System, A.D. 1250-1350 (Oxford: Oxford University Press, 1989); Roderich Ptak, China's Seaborne Trade with South and Southeast Asia, 1200-1750 (Burlington, VT: Ashgate, 1999); and Angela Schottenhammer, ed., The East Asian Mediterranean: Maritime Crossroads of Culture, Commerce, and Human Migration (Wiesbaden: Harrasowitz Verlag, 2008).

5. A comprehensive list of such work would require a series of substantial bibliographies for several subfields and is beyond the scope of this essay. Major works of scholarship contributing to our current understanding of multiple modes of connection across maritime Asia in the areas of literature, art history, and archaeology include Sheldon Pollock, The Language of the Gods in the World of Men: Sanskrit, Culture, and Power in Premodern India (Berkeley: University of California Press, 2009); Ronit Ricci, Islam Translated: Literature, Conversion, and the Arabic Cosmopolis of South and Southeast Asia (Chicago: University of Chicago Press, 2012); Elizabeth Lambourn, "From Cambay to Samudera-Pasai and Gresik: The Export of Gujerati Grave Memorials to Sumatra and Java in the Fifteenth Century, C.E.," Indonesia and the Malay World 31.90 (2003): 221-284; Elizabeth Lambourn, "Borrowed Words in an Ocean of Objects: Geniza Sources and New Cultural Histories of the Indian Ocean," in Irreverent History: Essays for M. G. S. Narayanan, edited by Kesavan Veluthat and Donald R. Davis, Jr. (Delhi: Primus Books, 2014), pp. 215-242; Pierre-Yves Manguin, A. Mani, and G. Wade, eds., Early Interactions between South and Southeast Asia: Reflections on Cross-Cultural Exchange (Singapore: Institute of Southeast Asian Studies Press, 2011); Himanshu Prabha Ray and Jean François Salles, eds., Tradition and Archaeology: Early Maritime Contacts in the Indian Ocean (Singapore: ISEAS Press, 2012); and John Miksic, Singapore and the Silk Road of the Sea, 1300-1800 (Singapore: NUS Press, 2013).

6. See, for example, Azyumardi Azra, The Origins of Islamic Reformism in Southeast Asia (London: Allen and Unwin, 2004); Francis Bradley, "The Social Dynamics of Islamic 
Revivalism in Southeast Asia: The Rise of the Patani School, 1785-1909" (Ph.D. diss., University of Wisconsin, 2010); Tansen Sen, Buddhism, Diplomacy and Trade: The Realignment of SinoIndian Relations, 600-1400 (Honolulu: University of Hawai'i Press, 2003); Toni Huber, Holy Land Reborn: Pilgrimage and the Tibetan Reinvention of Buddhist India (Chicago: University of Chicago Press, 2008); John Holt, The Buddhist Vishnu: Religious Transformation, Politics, and Culture (New York: Columbia University Press, 2004); and D. Christian Lammerts, ed., Buddhist Dynamics in Premodern and Early Modern Southeast Asia (Singapore: Institute for Southeast Asian Studies, 2015).

7. Peter van der Veer, The Value of Comparison (Durham: Duke University Press, 2016), p. 28.

8. J. Spencer Trimingham, The Sufi Orders in Islam (Oxford: Oxford University Press, 1971); Alexander Knysh, Islamic Mysticism: A Short History (Leiden: Brill, 2000), pp. 169-170.

9. Mark Sedgwick, The Making and Remaking of the Rashīdī Ahmadi Sufi Order, 17992000 (Leiden: Brill, 2005).

10. Nile Green, Sufism: A Global History (Malden, MA: Wiley-Blackwell, 2012), p. 82.

11. Marshall Hodgson, The Venture of Islam: Conscience and History in a World Civilization, vol. 2 (Chicago: University of Chicago Press, 1974).

12. See, for example, John Voll, "Sufi Brotherhoods: Transcultural/Transstate Networks in the Muslim World"; Christopher Bayly, "From Archaic Globalization to International Networks, circa 1600-2000," in Interactions: Transregional Perspectives on World History, edited by Jerry H. Bentley, Renate Bridenthal, and Anand A. Yang (Honolulu: University of Hawai'i Press, 2005), pp. 30-47, 14-29.

13. See, for instance, T. W. Rhys Davids, Indian Buddhism: Lectures on the Origin and Growth of Religion as Illustrated by Some Points in the History of Indian Buddhism (London: Williams and Norgate, 1891), and Max Weber, Gesammelte Aufsätze zur Religionssociologie II (Tubingen: J. C. B. Mohr, 1921).

14. Histories of Buddhism often narrate the proliferation of divisions within the sangha by referring to the emergence of and relationships between "sects," "schools," "fraternities," and "lineages." See, for example, Richard Gombrich, Theravada Buddhism: A Social History from Ancient Benares to Modern Colombo (London: Routledge, 1988); Peter Harvey, An Introduction to Buddhism: Teachings, History and Practices (Cambridge, UK: Cambridge University Press, 1990); and Rupert Gethin, The Foundations of Buddhism (Oxford: Oxford University Press, 1998). "Fraternity" continues to evoke (albeit distantly) the comparative framework of Christian traditions, whereas "school" and "lineage" remain closer to indigenous Southern Asian usage (e.g., darisana, vāda, paramparā), with differences of emphasis. "School" typically foregrounds doctrinal and philosophical distinctions among specialist groups; "lineage" refers to specialists related through any process of transgenerational transmission. "Order" may also be used to refer to subdivisions of the saingha, partly to foreground social-historical or historical-sociological comparison to Islam and Christianity (e.g., Anne M. Blackburn, Buddhist Learning and Textual Practice in Eighteenth-Century Lankan Monastic Culture [Princeton: Princeton University Press, 2001]). When referring to monastic lineages in what are now Sri Lanka, Thailand, and Burma, scholars generally prefer to use the contemporary emic terms.

15. See, for instance, Ryuichi Abe, The Weaving of Mantra: Kukai and the Construction of Esoteric Buddhist Discourse (New York: Columbia University Press, 1999).

16. See, for instance, Anne Hansen, How to Behave: Buddhism and Modernity in Colonial Cambodia, 1860-1930 (Honolulu: University of Hawai'i Press, 2007); and Patrick Pranke, 
"The Treatise on the Lineage of Elders (Vamsadīpanī): Monastic Reform and the Writing of Buddhist History in Eighteenth-Century Burma" (Ph.D. diss., University of Michigan, 2004).

17. Indeed, such markers of affiliation are prominently highlighted in traditional biographical literature of Sufis written in the Arabic genre of tabaqāt. For an English translation of one example in the account of a Sufi from Sumatra active in the Yemeni city of Zabid in the eighteenth century, see R. Michael Feener, "Abd al-Samad in Arabia: The Yemeni Years of a Shaykh from Sumatra," Southeast Asian Studies 4.2 (2015): 259-277.

18. Prapod Assavavirulhakorn, The Ascendancy of Theravāda Buddhism in Southeast Asia (Chiang Mai: Silkworm Publications, 2010), p. 45.

19. See, for instance, Peter Skilling, "The Advent of Theravāda Buddhism to Mainland South-east Asia," Journal of the International Association of Buddhist Studies 20.1 (1997): 1-17; Assavavirulhakorn, Ascendancy of Theravāda Buddhism; and Anne M. Blackburn, "Buddhist Connections in the Indian Ocean: Changes in Monastic Mobility, 1000-1500," Journal of the Economic and Social History of the Orient 58 (2015): 3. See also the chapters by Alexey Kirichenko, Kenneth Dean, and Amy Holmes-Tagchungdarpa in this volume.

20. A striking example of this reevaluation of earlier views on the subject can be found in the work of Anthony Johns, who published a poignant, self-reflective piece on his own earlier work, demonstrating this change in scholarly perspective on the early history of Islam in Southeast Asia. See Anthony Johns, "Islamization in Southeast Asia: Reflections and Reconsiderations with Special Reference to the Role of Sufism," Southeast Asian Studies 31.1 (1993).

21. Michael F. Laffan, The Makings of Indonesian Islam: Orientalism and the Narration of a Sufi Past (Princeton: Princeton University Press, 2011).

22. Nile Green, Indian Sufism since the Seventeenth Century: Saints, Books, and Empires in the Muslim Deccan (London: Routledge, 2006).

23. Jack Meng-Tat Chia, "Diasporic Dharma: Buddhism and Modernity across the South China Sea" (Ph.D. diss., Cornell University, 2017).

24. Although nothing similar yet exists for the maritime world of Southern Asia that is the focus of this volume, work along these lines has been done for the overland corridors of Central Asia in Johan Elverskog, Buddhism and Islam on the Silk Road (Singapore: Institute of Southeast Asian Studies, 2013).

25. R. Michael Feener, "Issues and Ideologies in the Study of Regional Muslim Cultures," in Islamic Connections: Muslim Societies in South and Southeast Asia, edited by R. Michael Feener and Terenjit Sevea (Singapore: ISEAS Press, 2009), pp. xiii-xxiv.

26. Blackburn, Buddhist Learning and Textual Practice; Anne M. Blackburn, Locations of Buddhism: Colonialism and Modernity in Sri Lanka (Chicago: University of Chicago Press, 2010).

27. Carl W. Ernst and Bruce Lawrence, Sufi Martyrs of Love: The Chisti Order in South Asia and Beyond (New York: Palgrave MacMillan, 2002), p. 11.

28. Devin DeWeese, Islamization and Native Religion in the Golden Horde: Baba Tükles and Conversion to Islam in Historical and Epic Tradition (University Park, PA: Pennsylvania State University Press, 1994), p. 137.

29. Frank Reynolds and Charles Hallisey, "Buddhist Religion, Culture, and Civilization," in Buddhism and Asian History, edited by Joseph M. Kitagawa and Mark D. Cummings (London: Macmillan, 1989).

30. See also R. A. L. H. Gunawwardana, "The World of Theravada Buddhism in History: Relevance of a Territorial Category as a Conceptual Tool in the Study of History," in Dhamma 
Vinaya: Essays in Honor of Venerable Professor Dhammavihari (Colombo: Sri Lanka Association for Buddhist Studies, 2005).

31. See Gregory Schopen, "Archaeology and Protestant Presuppositions in the Study of Buddhism," History of Religions 31 (1991): 1.

32. Steven Collins, Nirvana and Other Buddhist Felicities (Cambridge, UK: Cambridge University Press, 1998).

33. See, for instance, Donald K. Swearer and Sommai Premchit, "The Relationship Between the Religious and Political Orders in Northern Thailand (14th-16th Centuries)," in Religion and the Legitimation of Power in Thailand, Laos, and Burma, edited by Bardwell L. Smith (Chambersburg: Anima Books, 1978); Kanai Lal Hazra, History of Theravada Buddhism in South-East Asia (New Delhi: Munshiram Manoharlal, 1982); Jonathan Walters, "Buddhist History: The Sri Lankan Pali Vamsas and Their Commentary," in Querying the Medieval, edited by Ronald Inden, Jonathan Walters, and Daud Ali (Oxford: Oxford University Press, 2000), pp. 99-164; and Anne M. Blackburn, "Localizing Lineage: Importing Higher Ordination in Theravādin South and Southeast Asia," in Constituting Communities: Theravada Buddhism and the Religious Cultures of South and Southeast Asia, edited by John Holt, Jonathan Walters, and Jacob Kinnard (New York: State University of New York Press, 2003), pp. 131-150.

34. See Jonathan Walters, "Rethinking Buddhist Missions" (Ph.D. diss., University of Chicago, 1992); Anne M. Blackburn, "Sīhạ̣a Sanghha and Lañkā in Premodern and Early Modern Southeast Asia," in Lammerts, ed., Buddhist Dynamics, pp. 307-332.

35. For example, see Matthew Kapstein, The Tibetan Assimilation of Buddhism: Conversion, Contestation, and Memory (Oxford: Oxford University Press, 2002); Jacob Dalton, The Gathering of Intentions: A History of a Tibetan Tantra (New York: Columbia University Press, 2016).

36. See Sen, Buddhism, Diplomacy and Trade; Indrani Chatterjee, Forgotten Friends: Monks, Marriages, Memories of Northeast India (Oxford: Oxford University Press, 2013); and Elverskog, Buddhism and Islam on the Silk Road.

37. For contemporary developments among the Qādiriyya and the Shādhiliyya orders as they established local forms in more westerly sections of the Indian Ocean world, see Anne K. Bang, Islamic Sufi Networks in the Western Indian Ocean, c. 1880-1940 (Leiden: Brill, 2014), pp. 47-41.

38. For Buddhism, see Craig Reynolds, "The Buddhist Monkhood in Nineteenth Century Thailand” (Ph.D. diss., Cornell University, 1972); Kitsiri Malalgoda, Buddhism in Sinhalese Society, 1750-1900: A Study of Religious Revival of Change (Berkeley: University of California Press, 1976); Anne Hansen, How to Behave: Buddhism and Modernity in Colonial Cambodia, 1860-1930 (Honolulu: University of Hawai'i Press, 2007); and Amy Holmes-Tagchungdarpa in this volume. For Islam: Werner Kraus, Islamische mystische Bruderschaften im heutigen Indonesien (Hamburg: Institut für Asienkunde, 1990); Martin van Bruinessen, Tarekat Naqsyabandiyah di Indonesia (Bandung: Mizan, 1992); Sedgwick, Making and Remaking of the Rashīdī Ahmmadi Sufi Order; Marc Gaboriau, Le Mahdi incompris: Sayyid Ahmad Barelwî (1786-1831) et le millénarisme en Inde (Paris: CNRS Éditions, 2010); as well as the contributions by Torsten Tschacher, Ismail Alatas, and Martin van Bruinessen in this volume.

39. R. Michael Feener, "New Networks and New Knowledge: Migrations, Communications and the Refiguration of the Muslim Community in the Nineteenth and Early Twentieth Centuries," in The New Cambridge History of Islam, vol. 6, edited by Robert Hefner (Cambridge, UK: University Press, 2010), pp. 39-68; James L. Gelvin and Nile Green, eds., Global Muslims in the Age of Steam and Print (Berkeley: University of California Press, 2013); 
Mark Frost, “'Wider Opportunities': Religious Revival, Nationalist Awakening and the Global Dimension in Colombo, 1870-1920," Modern Asian Studies 36.4 (2002): 937-967; and Steven Kemper, Rescued from the Nation: Anagarika Dharmapala and the Buddhist World (Chicago: University of Chicago Press, 2015).

40. Ian J. Kerr, "Reworking a Popular Religious Practice: The Effects of Railways on Pilgrimage in 19th and 20th Century South Asia," in Railways in Modern India, edited by Ian J. Kerr (Oxford: Oxford University Press, 2001), pp. 304-327; and Elizabeth Nissan, "The Sacred City of Anuradhapura: Aspects of Sinhalese Buddhism and Nationhood." (Ph.D diss., London School of Economics and Political Science, 1985).

41. Thongchai Winichakul, Siam Mapped: A History of the Geo-Body of the Nation (Honolulu: University of Hawai'i Press, 1994); Toni Huber, The Holy Land Reborn: Pilgrimage and the Tibetan Reinvention of Buddhist India (Chicago: University of Chicago Press, 2008).

42. One area of future comparative work that could be particularly fruitful would be debates over projects of "modernizing" religious reform in both traditions-looking comparatively, for example, at developments in Buddhist Burma and Muslim Indonesia in the twentieth century. 


\title{
A HAADRAMĪ SUFI TRADITION IN THE INDONESIAN ARCHIPELAGO
}

\author{
The Itineraries of Ibn Yahyā (1794-1849) \\ and the Tariqa 'Alawiyya
}

ISMAIL FAJRIE ALATAS

The nineteenth century has been regarded by some scholars as marking the end of the dominance of Sufism and Sufi orders in the propagation and expansion of Islam in the Indonesian archipelago. ${ }^{1}$ The end of the eighteenth and the beginning of the nineteenth centuries, however, should not be seen as a mere transitory phase that bridges the period of early Islamization and the era of modern Islamic reformism. To the contrary, this period witnessed consolidations of Islamic thought and practices in the various regions where Islam had been adopted. ${ }^{2}$ Such processes were facilitated by the rise in the numbers of pilgrims to Mekka from the Indonesian archipelago, expanding networks of Islamic study centers and circulation of religious scholars as well as dynamic reconfigurations of Sufi "orders."

In this chapter, I examine the role of a Sufi tradition, the Țarīqa 'Alawiyya, in the transmission of Islam in the Malay-Indonesian archipelago at the beginning of the nineteenth century. ${ }^{4}$ I do this by focusing on an itinerant Hadrami scholar, 'Abdallāh b. 'Umar ibn Yahyā (1209/1794-1265/1849), who visited the Malay-Indonesian archipelago in 1832 and stayed there until 1835. Although recent works dealing with state formation in Hadramawt have highlighted the crucial role played by Ibn Yahyā, not much is known about his sojourn in Java. ${ }^{5}$ One reason for this is the scarcity of sources. Neither his hagiography (manāqib) nor his biographies (tarājim) substantially discuss his visit to Java. To address this lacuna, I reconstruct Ibn Yahyā’s travel to Java by using available documentary evidence including his poems and epistles.

I will suggest that a reconstruction of Ibn Yahyā's Javanese itinerary provides a contextualized glimpse into the development and expansion of the Țarīa 'Alawiyya in the early nineteenth-century Malay-Indonesian world, 
one that has implications for our broader understanding of religious "orders" in Southern Asia during the later colonial period. The consolidation of Dutch colonial authority and the defeat of the indigenous political and religious leadership following the Java War (1825-1830) provided Bā 'Alawī scholars from Hadramawt the opportunity to broaden their involvement in the region. The travels of Ibn Yahyā illustrate the gradual movements of Bā 'Alawī itineraries into more established stations during a period marked by major sociopolitical reconfigurations. The shifting Islamic landscape that resulted from these political dynamics opened up spaces through which itinerant Bā 'Alawī scholars were able to transmit their understanding of Islamic tradition in new ways. The hallmark of the Tarīqa 'Alawiyya during this period, as I will illustrate in this chapter, was a spirited sharī'a-oriented Sufism with a strong commitment to the implementation of Islamic law, the spread of simplified theological and legal knowledge, and the creation of peace and security through what they understood as a strong and legitimate political order.

In this chapter, I adopt Nile Green's definition of a țariqa (Sufi “order") as a formal and cultural mechanism of tradition. That is, a tarīqa is a conceptual and practical apparatus that reproduces standardized and consistent Sufi practice and doctrine through time and space. ${ }^{6}$ The notion of tariqa enabled the Sufi-oriented Muslims to conceive their doctrine and practices as something inherited, "as a cross-generational system of inheritance" or lineage capable of distinguishing one tradition from another within an encompassing religious community. ${ }^{7}$ Positing tarīqa as a practical mechanism of tradition allows us to trace the changing forms and shapes of a tarīqa as it encounters novel contexts and challenges in shifting historical contexts. Although participants in tariqa (Ar. pl. turuq) stressed the reproduction of standardized doctrine and practices within their orders as something inherited through lineal transmission, in actuality, what was reproduced varied across historical circumstances. In the case of the Țarīqa 'Alawiyya in the early nineteenth-century Malay-Indonesian world, this order, or mechanism of tradition, involved three dimensions that I elaborate in this chapter: trade, royal power, and scholarly networks bounded by a shared textual canon. These three dimensions served to promote and reproduce a distinct and standardized sharīa-oriented Sufism as a nineteenth-century articulation of the Alawiyyā tradition, establishing a distinct identity that could be accentuated to different degrees across changing historical contexts.

Reconstructing the itinerary of Ibn Yahyā from Haḍramawt in South Arabia to the Malay-Indonesian archipelago highlights the need to situate these separate regions as part of a historically cohesive space of diverse mobilities and intercultural transmissions and translations. Following Anne Blackburn and Michael Feener, I use the term "Southern Asia" to describe this "broad transregional geography that transcends the boundaries of modern academic area studies frameworks of 'South Asia' and 'Southeast Asia." "8 Whereas Feener and Blackburn define Southern Asia as a region "stretching from India, Sri Lanka, 
and the Himalayas through mainland Southeast Asia and across the Indonesian archipelago," in this chapter, I extend this useful geographic term to include South Arabia, where Haḍramawt is located..$^{9}$ Incorporating South Arabia as part of Southern Asia means situating the former as part of the historical circulation of people, ideas, objects, texts, and practices that made up the latter. As will be shown here, the development of a Sufi "order" like the Țarīa 'Alawiyya in the Malay-Indonesian archipelago cannot be separated from its contemporaneous development in Haḍramawt and vice versa. This fact in turn reinforces the need to observe (1) the role of itinerant actors — like Ibn Yahyā-in forming religious networks that linked these otherwise distant regions and in performing the work of transmission, and (2) the apparatus of religious "orders"-like the Tarīqa 'Alawiyya - in maintaining coherence in what was transmitted across time and space by structuring them in the framework of a lineage.

\section{NETWORKS AND ORDERS}

Recent works on Sufism have moved away from the notion of "religious order" that was employed by earlier scholars who analyzed Sufi tarīqa in relation to perceived similarities between tariq $a$ and the Christian monastic institutions of the medieval period. ${ }^{10}$ Shahzad Bashir, for instance, opts for the term "network" rather than "order" for its relative neutrality. The notion of "order," according to Bashir, "has led scholars to misapprehend the type of internal cohesion and discipline than can be attributed to the Sufi communities." ${ }^{11}$ Bashir's use of "network" to supplant "order" is geared toward understanding Sufi tarīqa on their own terms as a form of sociality that is historically contingent.

Although the term "network" captures the complex, nebulous, and historically contingent horizontal relations among adherents of a particular tarīqa, it does not in my view capture the ways in which tariqa have created their own modes of vertical interaction that have allowed them to produce a sense of coherence across time for their participants. And although Bashir's argument for the importance of embodied beliefs and practices as mechanisms that unite people into a moral community devoted to charismatic exemplars is well taken, religious groups assume a more complex and institutionalized form, such as a Sufi tarīqa, for example, "when the group finds it needs to acquire a representation of itself that can incorporate the idea of its continuity beyond the immediate context of its members' interrelating."12 Equally important is the fact that the informal connotation of the term "network" downplays the various techniques of boundary making that have historically been deployed by the adherents of a particular tariqqa to separate themselves from others. If we seek to comprehend the mechanisms of reproduction and authentication that have enabled each tarīqa to formulate a lineage that sustains a distinct identity vis-à-vis other tarìqa, we require an analytical framework that captures this temporal depth, which in my view is not adequately provided by the concept of "network." 
I suggest that the notion of "order" should be refined rather than completely abandoned as Bashir suggests. One reason for this is precisely because the term "order" is useful for comparative purposes. It allows constructive comparison across religious traditions that can shed light on the similarities and differences in the features of these traditions. Such features include their organizational infrastructure, conception of affinities, and mechanisms of reproduction, selfrepresentation, authentication, and lineage making. To this end, the case of Ibn Yahyaa is developed in this chapter to highlight the formal, material, and organizational infrastructure of the Alawiyyā tarīqa as a religious order. Moreover, I use the case of Ibn Yahyā to suggest important features that should be considered in refining and developing further the "religious order" as a comparative category. "Orders" are sustained by networks. Networks, however, are not stable over time, but are defined and organized through mechanisms that establish lineage and historical continuity, including the "chains of memory"-often in objectified forms like shrines or bodies of texts - that establish continuity within the order beyond the interpersonal encounters between its participants. ${ }^{13}$ The shape and character of an order's networks at particular moments in time are related to formal, material, and organizational infrastructure within and beyond the order. Even within a single religious tradition, such as Islam, the institutional infrastructure shaping and shaped by orders will differ significantly across time and place. Analytically, the notion of "order" is able to capture the intricate constructions of temporal continuity and geographic connectivity that enabled each tradition to develop a distinct lineage and coherent identity. Employing this concept, in turn, allows us to compare similar mechanisms across different religious traditions. With this in mind, let us now turn to Ibn Yahyyā.

\section{IBN YAHYĀ AND THE ṬARĪQA 'ALAWIYYA IN ḤADRAMAWT}

Ibn Yahyyā was born in the town of Ghuraf āl-Shaykh-a settlement founded by his ancestor Shaykh b. Aḥmad ibn Yahyyā — on 20 Jumād I 1209 (December 13, 1794). ${ }^{14}$ He studied under his parents and two maternal uncles, Țāhir (d. 1229/1814) and 'Abdallāh b. Ḥusayn ibn Țāhir (d. 1272/1855). It was 'Abdallāh who first formally initiated him into the Tarīqa 'Alawiyya. Ibn Yahyāa also studied under influential Bā 'Alawī scholars of Ḥaḍramawt, including 'Umar b. Saqqāf al-Saqqāf (d. 1216/1801) and his brother 'Alawī (d. 1235/1819), al-Ḥasan b. Șāliḥ al-Baḥr al-Jufrī (d. 1273/1856), and Aḥmad b. 'Umar ibn Sumayṭ (d. 1258/1842). ${ }^{15}$ His teachers from among the non-Bā 'Alawī Haḍramī scholars included 'Abdallāh b. Aḥmad Bā Sawdān (d. 1266/1849) and 'Abdallāh b. Sa'ad ibn Sumayr (d. 1262/1846). ${ }^{16}$ Ibn Yahyā also studied with 'Abd al-Raḥmān b. Sulaymān al-Ahdal (d. 1250/1834) in Zabīd, Yemen, and 'Umar b. 'Abd al-Karīm b. 'Abd al-Rasūl al-Ațtāar (d. 1249/1833) in Mekka.

Ibn Yahyầ's biographical account illustrates how the transmission of Islamic knowledge and practices in Haḍramawt took place in informal study 
circles that revolved around a particular teacher. ${ }^{17}$ There is no mention of Ibn Yahyā enrolling in a formal educational institution or in Sufi lodges (zawāya ; arbita) despite their existence throughout South Yemen since the seventh/thirteenth century. ${ }^{18}$ In Hadrramawt, however, the first formal educational institution was only founded as late as $1878 .{ }^{19}$ Ibn Yahyā's initiation into the tariqa was thus accomplished by studying with and being in the company of scholars who had been initiated into the tarīqa by their predecessors. The education also involved visiting the tombs and mosques of the Bā 'Alawī predecessors, where Sufi audition and concert $(\operatorname{sam} \bar{a})$ were performed on a regular basis. ${ }^{20}$ In the absence of formal educational institutions or Sufi lodges, such practices enabled scholars like Ibn Yahyā to conceive the standardized Islamic doctrines and practices he was immersed in as something coherent and inherited through lineal transmission, thereby providing them with temporal depth and distinct genealogical identity.

The hagiography describes how the young Ibn Yahyā traveled from one place to another to read texts under different scholars, all of whom had their own followings. From these scholars he acquired the proper authorizations (ijāza) and initiations into the tarīqa (tahkīm), providing him with tangible links to previous masters that also created social bonds with his fellow students. The Tarīqa 'Alawiyya in Haḍramawt did not, however, develop the elaborate economic and institutional structures that characterized large organized Sufi orders found in some other areas of the Muslim world. According to Alexander Knysh, this may be attributable to a "lack of resources on the part of Yemeni ruling elites" that barred the rulers from endowing Sufi lodges and economic foundations for the growth of the tariqa. ${ }^{21}$ In addition, intrinsic political instability and fragmentation due to the absence of a powerful centralized political order may have contributed to this reality. ${ }^{22}$ Under such conditions, formal elements like the bond of allegiance ('uqda) between masters and disciples together with chains of initiations ( silsila) functioned to generate a sense of both vertical and horizontal identity and solidarity among the initiates. Among the Bā 'Alawīs, such formal elements intensified vertical and horizontal connections that were already present through kinship ties.

By studying with the leading scholars of his day, Ibn Yahyā concurrently formed his spiritual connection to the deceased scholars through grave visitations and was gradually able to emerge as an important node in the intellectual genealogy of the Tarīqa 'Alawiyya himself. The scholar 'Aydarūs b. 'Umar al-Habashī (d. 1314/1896) — author of the 'Iqd al-yawāqìt (A knot of rubies), a compilation of the initiatory chains of the Țarīa 'Alawiyya-listed Ibn Yahyā as one of the nineteen crucial nodes that linked Bā 'Alawī scholars of the eighteenth century to those of the nineteenth and twentieth centuries. Al-Habashī described how he studied several texts under Ibn Yahyā's guidance, including the legal primer al-Minhaj of the Syrian jurist al-Nawāwī (d. 676/1278) and the Bā 'Alawī Sufi manual Fath al-khallāq of 'Abd al-Raḥman b. 'Abdallāh 
Bilfaqīh (d. 1162/1748). Ibn Yaḥyā initiated al-Habashī into the țarīqa in 1845 and renewed the initiation in 1848 at the mausoleum of the eponymous ancestor of the Bā 'Alawī. He also gave al-Habashī the authorization to recite a collection of Bā 'Alawī litanies and prayers (adhkār wa awrād) compiled by Ibn Yahyyā's teacher and uncle Țāhir. ${ }^{23}$

Al-Habashī's account reveals the dynamics of educational practice and ritual socialization among the Bā 'Alawī in early nineteenth-century Haḍramawt. Learning consisted mainly of reading Islamic legal texts in conjunction with Bā 'Alawī Sufi manuals under the direction of senior scholars, who in turn bestowed the licentia docendi (ijāza) to the students. In some cases, it also involved initiation into the tarīqa, usually formalized by the bestowal of a cloak of investiture (khirqa). ${ }^{24}$ Equally important were visits to the graves of those perceived to be the luminaries of the tariqa. The tariqqa also stressed the recitations of litanies and prayers, usually compiled and organized by the Bā 'Alawī predecessors to facilitate guided ritual recitations. Together with other formal elements, these litanies served as proprietary practices that differentiated the adherents of the tariq $a$ from other Muslims. The tariqqa therefore provided an institutional rubric binding a historical community-consisting of both the dead and the living - through a sense of shared canonical texts, practices, rituals, sacred spaces, and litanies. These elements were reproduced through a chain of master-disciple relationships, thereby forming a perceivable lineage and historical continuity with clear boundaries.

Most of Ibn Yahyā's teachers were working under the reformed paradigm of the tarīqa set by the influential eighteenth-century scholar 'Abdallāh b. 'Alawī al-Haddad (d. 1132/1720). Motivated by a drive to reform society, al-Haddād reshaped the teachings of the tarīqa from their earlier emphasis on individual devotional efforts into a set of moral and ethical guidelines for both the elites and the masses. ${ }^{25}$ Following al-Haddād, the tarīqa in the early nineteenth century was marked by a combination of the commitment to the sacred law and its implementation, the spread of simplified legal and theological knowledge, and the creation of peace and security through a strong and legitimate political order. Such a vision was by no means unique to the Țarīa 'Alawiyya. In fact, since at least the sixteenth century, different Sufi orders placed a great emphasis on the law-abiding moral rectitude of the Sufis as a social role model for Muslims in general, an emphasis that made Sufism attractive to state administrators. Sufism as it developed in different parts of the Muslim world at that time had grown into "a powerful idiom of collective organization and communal solidarity," which went hand in hand with the systematic attempts of several Islamic polities to demote "the nomadic, charismatic, and 'anarchistic' Sufism associated with rural tribal groups." 26 The reformed paradigm of al-Haddād should therefore be situated in relation to these broader developments.

Ibn Yahyā himself was known for his mastery of Islamic law, especially the Shāfi' 1 legal school. ${ }^{27}$ Appointed as the mufti of Haḍramawt at a relatively young 
age, Ibn Yahyā emphasized the learning and teachings of Islamic law as the most crucial step to the attainment of a higher spiritual state. ${ }^{28}$ Rather than seeing the law and Sufism as two different entities, he posited Sufism as an intensification of the law ultimately geared toward emulation of the Prophet, a position that had a long precedent in the history of Sufism. In Ibn Yahyā's view, spiritual wayfaring is a process of emulating the Prophet and, as such, knowing the correct forms of practices pursued along this path constitutes the first crucial step.

In Haḍramawt the Ṭarīqa 'Alawiyyā developed as sporadic kinship and scholarly networks. Rather than seeing it as an exclusive Sufi fraternity that emerged from a particular lodge, it is more accurate to comprehend the tariqa as a mechanism of tradition sustained by a dispersed network of master-disciple relationships devoted to the promotion of a sharī'a-oriented Sufism. This mechanism of tradition involved rituals, sacred spaces, and liturgies to develop concrete bonds of vertical and horizontal connectivity. It also comprised formal apparatuses including ' $u q d a$ (pledge of allegiance between a disciple and his or her Sufi master), khirqa (ritual robe of investiture, usually of distinctive design or color), and silsila (chain of spiritual genealogy of master-disciple links), all of which functioned to constitute its discursive boundaries and define its historical and lineal identity. The shape and character of a particular tariq $a$, however, was also intricately linked to the formal, material, and organizational infrastructure available to it at a particular time or in a particular region. In what follows, I will turn to Ibn Yahyā's travel to the Indonesian archipelago to examine the development of the Tarīqa 'Alawiyyā in that region.

\section{ISLAM, TRADE, AND POLITICS IN THE INDONESIAN ARCHIPELAGO}

Beginning as early as the seventeenth century, the Bà 'Alawīs began to emigrate in increasing numbers to different places in Southern Asia, including India, Malaya, and the Indonesian archipelago. ${ }^{29}$ Internal strife and limited opportunities in Haḍramawt together with the ample economic opportunities abroad drove many Bā 'Alawī to leave their homeland. Thriving port cities including Malacca, Aceh, and several Javanese port cities became the preferred destinations for many. These cities became the bases from which the migrants traveled both inland and to other islands, where they established trading ventures. Before the consolidation of British and Dutch colonization, the Bā 'Alawīs had already established themselves in prominent positions in the regions, with some even assuming the position of sultans. ${ }^{30}$

Advances in maritime transportation in the early nineteenth century resulted in the increasing presence of Haḍramī Arabs in the region. ${ }^{31}$ The sphere of Hadramī mercantile activities was for the most part centered on the sea and the littorals. Shipping was their dominant economic activity until the middle of the nineteenth century. Beginning in the mid-1750s, Hadramīs specialized in 
sailing from Java to Palembang and Malacca, with an average ship size of over fifty tons. William G. Clarence-Smith has noted that "from $22 \%$ of the registered tonnage of square-rigged ships in 1820 , Arabs went to just over $50 \%$ in 1850 , compared to $29 \%$ for the Chinese, $9 \%$ for the Dutch, $9 \%$ for the British, and 3\% for "natives." "32 This expanding world of Haḍramī merchants provided the foundation for the expansion of the Tarīqa 'Alawiyya, as will be shown in the next section.

When Ibn Yahyā arrived in Java in 1833, the island had just recovered from an extended war between the composite forces that made up the supporters of Prince Dipanegara and the Dutch colonial regime. ${ }^{33}$ The Java War had begun in 1825 and ended in 1830 with the victory of the colonial forces. The conclusion of the war left the colonial regime with no serious competitor to its increasing power, allowing it to refocus on profit acquisition. The new governor general, Johannes van den Bosch (d. 1844), enacted an agricultural reform plan to facilitate the extraction of agricultural products from Java in quantities and at prices that would make the Netherlands Europe's biggest supplier of tropical products, especially coffee. ${ }^{34}$ The cultivation system helped the Dutch to rebuild Holland's economy following the ravages of the Napoleonic war and the Belgian secessionists. In Java, it led to a neofeudalization, converting and buttressing a priyayi class of Javanese elites to colonial intermediaries. ${ }^{35}$

The monetization of the agricultural economy resulted in flourishing trade, which then led to an increase in the number of Javanese pilgrims to Mekka. ${ }^{36}$ By the $1850 \mathrm{~s}$ and $1860 \mathrm{~s}$, an average of approximately 1,600 pilgrims set out from the Netherlands Indies annually, despite the colonial authority's attempt to discourage them from going. ${ }^{37}$ In Mekka, they were exposed to diverse visions of Islamic reform and the revival movements of the early nineteenth century. On their return to Java, many of these pilgrims challenged the social positions of established rural teachers and attempted to carve a niche for themselves and their enthusiastic transmission of what they had learned in Mekka to their fellow Javanese Muslims. Nineteenth-century Java was a conflictual and competitive "religious marketplace" where competing visions of Islam vied against each other while state patronage and resources were rapidly diminishing. ${ }^{38}$

One Islamic vision gaining ground during the period was sharīa-oriented Sufism. By the early 1800s, the works of Egyptian Sufi-oriented scholars, emphasizing the dissemination of simplified texts on legal and ethical guidance, had begun to replace the earlier Medinese tradition of Sufism with its emphasis on Sufi philosophical teachings. ${ }^{39}$ This new trend worked to restrict the dissemination of the more speculative Sufi treatises to a small religious elite, while laying the foundation for what later became the standard Islamic curriculum in Java and across other areas of the Indonesian archipelago. This curriculum situates a thorough immersion in relatively simplified legal and theological tradition under the guidance of a competent teacher as a prerequisite to mystical 
training. The gradual process of curricular standardization in turn demanded a cohort of trained scholar-instructors.

The dissemination of this sharīa-oriented Sufism was facilitated by the emergence of new Islamic educational institutions, the pesantren (rural Islamic religious schools), across Java. The aftermath of the Java War witnessed the movement of Muslim scholars - many of whom were involved with the insurrection - away from the royal court into the countryside and the littoral, resulting in the rapid increase of new pesantren. ${ }^{40}$ According to the colonial survey of education in Dutch Java, Cirebon, Semarang, and Surabaya had the largest number of pesantren. In 1831, Cirebon had 190 with a total of nearly 2,800 pupils; Semarang had 180 with a total of almost 3,000; and Surabaya, a total of 2,600 pupils. ${ }^{41}$ The Great Post Road, linking the western to the eastern tip of Java, was completed in 1808, facilitating greater communication between pesantren and allowing students to move more easily from one institution to another. ${ }^{42}$ These pesantren served as the nodes of intellectual exchanges through which a new Islamic curriculum — based on sharī‘a-oriented Sufism-was developed.

Central to this emerging Islamic vision was an insistence on the performance of the five daily prayers along with heightened observation of other "pillars of Islam." These practices, according to Ricklefs, became key elements during this period differentiating the reformed Muslims from the adherents of the prior and long-established Islamic tradition in Java. Ricklefs argues that among the adherents of the old religious tradition - what he describes as "the mystic synthesis" — “those who practiced the 'perpetual salat [prayer]' did not see a need to perform 'the (ordinary) salat' with ablutions." "43 Ibn Yahyā should be placed within the development of this diverging vision of a reformed Islam that historians like Ricklefs and Laffan have detailed. As noted above, Bā 'Alawī Sufi scholars of Haḍramawt, including Ibn Yahyā himself, were influenced by the wider turn of Sufi thought in the Middle East toward legal-oriented Sufism.

The itineraries of wandering Haḍramī scholars like Ibn Yahya should therefore be situated alongside the expansion of trade networks and other Sufi traditions that paved the way for the emergence of a new vision of shari'a-oriented Islam. At the same time, such a dynamic landscape was often marked by conflicts, contestations, and competitions among different scholars representing different Sufi traditions. As such, a distinct religious order like the Tarīqa 'Alawiyya should not be examined in isolation from other intellectual developments in overlapping networks within the encompassing religious community of Javanese Islam. With this shifting historical context in mind, I will now turn to the three dimensions of the Tarīqa 'Alawiyya in the early nineteenth-century Indonesian archipelago that I have identified through my reconstruction of Ibn Yahyā's journey, namely, trade, royal power, and scholarly networks bound by a shared canon of texts. I will illustrate how these three dimensions served to create and reproduce a distinctly Bā 'Alawī vision of a standardized sharī'a-oriented Sufism. 


\section{TRADE}

When Ibn Yahya traveled to Singapore in 1832, he was entering the expanding and prosperous world of the Hadramī diaspora. Since its establishment in 1819, Singapore had attracted merchants from various ethnic communities, including Hadrramīs from all over Malaya and the Indonesian archipelago. Among them was the wealthy Bā 'Alawī merchant 'Umar b. 'Alī al-Junayd (d. 1269/1852), with whom Ibn Yahyā stayed during his sojourn in the port city. Al-Junayd had come to Singapore from Palembang shortly after Raffles established Singapore. He brought his accrued wealth from Sumatra and invested in Singapore, buying lands and developing properties that led to the substantial expansion of his family's fortune. He built what today is known as the first mosque in downtown Singapore in 1820 . He was also in the habit of sending money for the maintenance and renovation of the tombs and mosques of the Bā 'Alawi ancestors. ${ }^{44}$ Al-Junayd's wealth together with his philanthropic passion and enthusiasm for the Țarīqa 'Alawiyya attracted several members of the Hadrramī scholarly elites to Singapore. It is no surprise that al-Junayd became Ibn Yahyā's destination in Singapore.

Among the Hadramī scholarly elites in Singapore who revolved around al-Junayd was the jurist Sālim b. 'Abdallāh ibn Sumayr (d. 1853). Ibn Sumayr had migrated to Singapore several years before Ibn Yahyā and had begun teaching there, presumably with the financial support of al-Junayd. His study circle attracted advanced students from Singapore and Java. ${ }^{45} \mathrm{Ibn}$ Sumayr was a close friend of Ibn Yahyā; the former's father was one of the latter's teachers. Ibn Sumayr had traveled to the Hijāz and India before settling down in Batavia and Singapore. He was the author of a legal abridgment (mukhtașar), the Safināt al-najāh (Ark of salvation), which became popular in Southeast Asia as a basic primer for the study of Islamic law. This short text continues to be studied in Islamic boarding schools across Java today. ${ }^{46}$ Ibn Sumayr was also known for his active condemnation of Sufi teachers who initiated "ignorant masses" into their țariqa without basic knowledge of Islamic law. While such a position exemplified the reformed paradigm of the Tarīqa 'Alawiyya, it also provided incoming Hadramī scholars with the necessary discursive arsenal to criticize other Sufi orders active in the religious marketplace of the early nineteenthcentury Malay-Indonesian archipelago. At the same time, it allowed scholars like Ibn Yahyā and Ibn Sumayr to introduce their țarīqa as being strictly based on Prophetic teachings. Accessible Haḍramī legal primers, like that of Ibn Sumayr, gradually became popular all over Malaya and the Indonesian archipelago and more so as Singapore became a major center of Islamic publication in the late nineteenth and early twentieth centuries. ${ }^{47}$ These texts constituted one way through which the Bā 'Alawī vision of sharī'a-oriented Sufism spread in the region. 
Apart from establishing connection with the wealthy Haḍramī community of Singapore, Ibn Yahyā also visited the Haḍramī merchant elites of Java. ${ }^{48}$ Among the poems he wrote during his sojourn in Java were four poems naming and dating the construction of new boats owned by Haḍramī merchants in Surabaya. ${ }^{49}$ Interestingly, Ibn Yahyyā named these vessels after Bā 'Alawī saints. In one poem, he named a vessel al-Saqqāf, adding that "the named will be under the protection of the name," referring to the Bā 'Alawī saint 'Abd al-Raḥmān b. Muhammad al-Saqqāf (d. 819/1416), who instituted many of the ritual practices of the Tarīqa 'Alawiyya. ${ }^{50}$ Ibn Yahyā also used these poems to counsel the owners of the vessels in basic Islamic teachings, especially on spending their accrued wealth in accordance with the teachings of the tariqa . Designating trading vessels with the names of $\mathrm{B} \overline{\mathrm{C}}$ 'Alawì saints established historical connections between the boats, their owners, the wealth that these boats generated, and the saints' tombs in Hadramawt. Like the tombs, the boats constituted "chains of memory" that produced a sense of historical continuity. This historical connection in turn provided the trajectory through which profits generated by the boats could be channeled into the maintenance of the tariqa's infrastructure, such as the conservation of al-Saqqāf's tomb in Haḍramawt. It allowed the reproduction of the Bā 'Alawī saints' memory among the merchant elites, establishing semiotic ties that diachronically connected them to the saints. Such a practice also reproduced horizontal connectivity in the form of network and social bonds among these merchants and other adherents of the tariqa, including scholars like Ibn Yahyā and their brethren in Haḍramawt. Just as an initiation ceremony formally inducts a living body into a religious order and adopts him or her into its lineage, such symbolic gestures formally imbued these vessels with clear pedigrees, thereby repositioning them as the material apparatus of the tariqa. Such activities exemplify the process identified earlier in this chapter in which the shape of a religious order, in this case the Tarīqa 'Alawiyya, at particular moments owes much to the available material and organizational infrastructure in which it functions, which, in turn, allows for different practices of lineage making.

The expanding and prosperous world of the Hadramī economic diaspora, therefore, constituted one dimension of the Țarīqa 'Alawiyya in this period. It acted as an important mechanism of tradition that allowed the reproduction of a standardized Bā 'Alawī Sufi practice and doctrine with a distinct historical identity and lineage. The Haḍramī merchants assumed the role of patrons for traveling Bā 'Alawī scholars like Ibn Yahyā and Ibn Sumayr, who then articulated the sharī'a-oriented doctrines and practices of Bā 'Alawī Sufism. Financially supported by the Hadramī merchant elites, these scholars were able to provide spiritual guidance, instructing these merchant families and other Muslims in the basic teachings of the tariqa. Although today legal abridgments like The Ark of Salvation are used in Islamic boarding schools throughout the Indonesian archipelago, it may also be the case that they were initially composed to provide 
accessible teachings of the tariqa to these merchant elites and their families. Proper education for the children of these merchant elites seems to have been a central preoccupation of Ibn Yahyā. In a poem written during his stay in Singapore, Ibn Yahyā implores al-Junayd to send his children to Haḍramawt for proper education that they might become acquainted with the tarīqa of their ancestors. ${ }^{51}$ Without proper education and ritual socialization, it was feared that the children of these wealthy Haḍramī merchants would lose their attachment to the tariqqa.

At the same time, interactions between traveling scholars and the Hadramī merchant elites reshaped the tarīqa. Such networks allowed the construction of new material infrastructures, like merchant boats, that were mechanisms for the identification and unification of the order. Whereas some Sufi orders during this era were characterized by landholdings, lodges, and caravanserais, Bā 'Alawī sharī'a-oriented Sufism depended on a different kind of infrastructure, the multilocal and prosperous world of the Hadramī economic diaspora and its merchant patrons. For merchant elites and their families, the Țarīa 'Alawiyya and connections to its scholarly elites offered a sense of prestigious history, inherited tradition, social bonds, and translocal geographic connectivity. These provided a distinct lineage and coherent identity, thereby differentiating them from other merchant communities, Muslim and non-Muslim.

\section{ROYAL POWER}

As previously noted, the aftermath of the Java War witnessed the movement of Muslim scholars away from the royal courts and into rural Islamic religious schools (Jv. pesantren). This shift provided an opportunity for Haḍramī scholars to take over prominent religious positions, which would enable them to extend their influence through attaining prominent positions within the reconfiguration of courts of Southeast Asian sultanates in the colonial period. There is a long historical precedent attesting to the relationship between Sufi tarīqa and ruling structures. Sufi țariqa have historically been able to develop their institutional structure through royal patronage. Rulers have traditionally sought legitimacy through the patronage of influential Sufi scholarly families who held sway among the populace. These rulers acted as grantors of pious endowments (waqf) supporting the infrastructural development of tarīqa. They also accorded Sufi scholars prominent posts in the bureaucratic administration. These scholars in turn connected sultans to wider Islamic intellectual currents and enhanced their positions as legitimate leaders of their communities. ${ }^{52}$

Such dynamics are clearly articulated in the letters that Ibn Yahyā wrote to local rulers in the Indonesian archipelago. The compilation of Ibn Yahyā's correspondence includes three extant letters addressed to different rulers. The first was addressed to the Bā 'Alawī sultan Uthmān b. 'Abd al-Raḥmān al-Qadrī of Pontianak, Borneo. The second letter was addressed to the Pakunataningrat, 
the hereditary ruler of Sumenep on the island of Madura, off the northeast coast of Java. A third was addressed to Sultan 'Abd al-Qādir b. 'Abd al-Raḥmān Tjakraadiningrat II (d. 1847) of Bangkalan, also on Madura. ${ }^{53}$ As the form and content of the three letters are similar, in what follows I will limit myself to a close reading of the letter written to the ruler of Bangkalan. ${ }^{54}$

Written in Surabaya in 1833, the text is framed as a letter of scholarly advice and counsel (munāṣaḥa wa tawāṣ̂̄) to a ruler in an epistolary genre that goes back to the classical period of Islam. ${ }^{55}$ In the letter, Ibn Yahyā explained his motivation for writing to the sultan in such terms:

And the thought surfaced to address this writing [al-kitāb] to your high stature ['ali al-janāb] to fulfill the task ordered by the Lord of the lords [rabb $a l-a r b \bar{a} b]$ on those who were given knowledge and the Book [al-kitāb] to instruct it to the people and explain it to them [bayyanūh] without circumventing or concealing it from them [yuktamūh] and to strive to counsel the brethren $[a l-i k h w \bar{a} n]$ from all the people of the faith [al-īmān] especially those with power [dhā sultān $]$ as stated by the most distinguished creation of the Most-Merciful [al-rahmān]. Religion is counsel [al-nașīha] for the sake of God, His messenger, His books, and to the leaders of the Muslims and their common folk.

In that hadith, the Prophet specifically refers to the leaders and judges, because when they are counseled, it becomes possible to reform the conditions of both the elites and the masses, thereby perfecting the [social] structure. If one turns away from advising them, then the worst condition will befall the state and its people. So know, may God strengthen and guide you, that our master the Prophet - peace be upon him —initially invited everyone to embrace Islam. He then instructed them to perform prayers and made it incumbent upon them. But if they repent and establish regular prayers and practice regular charity, then open the way for them [Q. 9:5]. ${ }^{56}$

Consequently, Ibn Yahyā continues, it is incumbent upon any ruler to instruct and even to compel his subjects and those under his authority to perform prayers. Failure to do so would result in the calamities experienced by people of the past:

So it is incumbent upon every ruler to instruct his Muslim subjects who live in his dominion to perform prayers. And to force them if they decline to do so even if they have to be killed, in accordance to what has been explained by the scholars in following the footsteps of the Prophet, and to maintain what has been instructed by his Lord. And verily God commanded us to follow the Prophet and to hold fast to his laws. Follow what has been sent down unto you by your Sustainer, and follow no masters other than Him. 
How seldom do you keep this in mind! And how many a community have We destroyed, with Our punishment coming upon it by night or while they were resting at noontide! [Q. 7:3-4]. ${ }^{57}$

Ibn Yahyā further advised the sultan to honor and implement the sacred law, especially the obligation to perform collective prayers five times a day and to have the call to prayer ( $a d h \bar{a} n$ ) be clearly heard in the streets and the markets:

What we requested from your lordship - may God advance his condition and aid his religion by strengthening its pillars - is for you to strive truly with utmost perfection in resuscitating Islam's greatest symbol. And that symbol is the injunction and commandment for both the elites and the masses of his dominion and all of his subjects to perform the five obligatory prayers in the beginning of their times. And that you make the call to prayer manifest and organize communal prayers in every village. Verily, prayer is the pillar of religion. It is a mark that differentiates the Muslims from the infidels. It restrains from shameful and unjust deeds [Q. 29:45], elevates the ruler, and affords him victory over his foes. Allah will certainly aid those who aid his [cause]; for verily Allah is full of Strength, Exalted in Might; those who, if We establish them in the land, establish regular prayer and give regular charity enjoin the right and forbid wrong [Q. 22:40-41]. ${ }^{58}$

He ended the letter with a warning:

So hasten to this honor [makārim] and execute it with strong determination and resolution ['azáa'im]. Attain aspiration [al-munā], esteem, and splendor $[\operatorname{san} \bar{a}]$ in the hereafter and here $[$ hun $\bar{a}]$. Thank God for what He has bestowed upon you in the form of kingdom and delight [ni' $m a$ ] by upholding what is incumbent upon you in terms of service [khidma]. For what is truthfully required from the ruler is the improvement of religion and teaching the ignorant $[j u h h \bar{a} l]$ while instructing them to perform righteous deeds $\left[a^{i} m \bar{a} l\right]$. Verily, if he thanks God by commanding his subjects to pray [șalāt] and [to observe] all that has been ordained by his Lord [mawla], God's bounty will abide with him [ni'ma] and repel his enemies and those who are envious of him [ $\left.a^{i} d \bar{a} h\right]$. But if he becomes lenient in these biddings $\left[a^{i} m \bar{a} l\right]$ and leans toward the path of ignorant kings [al-mulük al-juhhāl], then he jeopardizes the delights to wither [li' $l$ zawāl] if you are grateful, I shall give you more; but if you are ungrateful, verily, my chastisement will be severe indeed [Q.14:7]. So hurry, hurry [fā

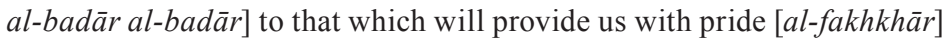
and complete esteem and zenith [al-manār] in this abode and in the final abode [dār al-qarār $].{ }^{59}$ 
Like the other two letters to local rulers, this letter to Sultan 'Abd al-Qādir of Bangkalan exemplifies an explicit moral discourse communicated eloquently. The potential sting of the advice is removed by the deployment of poetic language ornamented with Qur'ānic verses and rhymed prose. The formal composition of the letter itself is a moral performative, demonstrating the proper way of addressing a ruler. Hence, the letter frames the interaction as that between an Islamic scholar and a powerful ruler, both having moral obligations and responsibilities. Such a framing was especially important when the actual power of local kingdoms was rapidly diminishing in the face of the Dutch colonial expansion. The performative dimension of the letter thus functioned to safeguard the dignity of the increasingly weakened monarchs by fostering particular types of ethical interactions.

Ibn Yahyā's correspondence to local rulers can thus be read as attempts to persuade these power holders to implement and realize the Bā 'Alawī sharī'aoriented vision of Islam more forcefully in their dominions. Note, however, that Ibn Yahyā did not invite the rulers to pledge their allegiance to the Tarīqa Alawiyya. Rather, he was more interested in communicating the practical teachings of the tariqqa than in dwelling on its institutional structures and composition. His correspondence thus illustrates the crucial point that the dissemination of the Tarīqa 'Alawiyya in the early nineteenth century took on the form of the expansion - ideally with the assistance of royal power-of the shari'abased vision of Islam, which is not necessarily based on formal affiliation to an order. In this fact, we can glimpse an important dimension of the history of Islam in the region that would be difficult to appreciate if one viewed the tariqa as an "order" only in the sense of an institutional structure.

Ibn Yahyā's engagement with local rulers was thus part of an ongoing effort by the Bā 'Alawī sayyids to gain influence and position in the region. Indeed there seems to be an increase in their penetration of royal courts in the archipelago from the late eighteenth century onwards. One famous example was Ibn Yahyyā's contemporary, the Bā 'Alawi scholar Shaykh Aḥmad Bā Faqī (d. 1289/1872). Born in the port of al-Shiḥr on the coast of Haḍramawt, Bā Faqị traveled to Surabaya before moving to the Maluku Islands to set up trade. He later became acquainted with the ruler of Sumenep, Madura - the Pakunataningrat — who invited Bā Faqī to his family. Bā Faqī ṣ spent twenty-five years in Sumenep, where he commanded considerable influence in the royal court. ${ }^{60}$

Attachment to the royal courts and the ability to influence society that came with it allowed Bā 'Alawī scholars to disseminate their teachings more forcefully. Although there was certainly a degree of status and financial stability to be gained from being connected to royal courts — even at a time of diminishing royal power-Ibn Yahyā's attempt to influence local rulers should also be situated in a longer trajectory of Bā 'Alawī commitment to the implementation of the sacred law, the spread of simplified legal and theological knowledge, and the 
promotion of a strong and legitimate political order. Such engagements placed local ruling structures in the service of the Bā 'Alawī Sufi order. Royal power functions as a significant mechanism for the reproduction and implementation of particular forms of Islamic doctrine and practices. This second dimension of the Tarīqa 'Alawiyya in the early nineteenth-century Malay-Indonesian archipelago is thus marked by engagement with, rather than disassociation from, royal power. As Sufi orders like the Shațāriya, the Sammaniyya, and the Khalwatiyya were moving away - albeit without fully detaching themselvesfrom the royal courts and were developing in various sites of learning closer to the general population from the mid-eighteenth century onwards, Bā 'Alawī scholars continued to make inroads into the circles of the local ruling elites. ${ }^{61}$ The sharī'a-oriented Sufism envisioned by Bā 'Alawī scholars like Ibn Yahyā offered ideological means of reinforcing royal authority. Aside from providing rulers with powerful idioms of collective organization and ruling ideology, as members of wider Islamic scholarly networks, traveling Bā 'Alawī scholars were, to a certain extent, able to validate their aspiration and claim to the mantle of "defenders of Islam."

\section{SCHOLARLY NETWORKS}

The last dimension of the Țariqa 'Alawiyya in this period was the establishment of Islamic scholarly networks connected by a shared canon of texts. The dissemination of sharīa-oriented Sufism in the Indonesian archipelago was facilitated by the proliferation of pesantren across the region in the nineteenth century. At the same time, new infrastructure, including the Great Post Road, allowed the intensification of communication between Muslim scholars living in different places. Ibn Yahyā attempted to tap into these networks and use them to transmit the Bā 'Alawī vision of a sharī'a-oriented Sufism to the broader public.

Such an endeavor can be observed through the tadhkira (reminder), he wrote at the request of a number of Javanese scholars who studied with him in Surabaya. ${ }^{62}$ This short text illustrates Ibn Yahyyā's engagement with local scholars and his attempt to redefine the canon of Islamic texts while establishing an intellectual genealogy between local scholars and the Bā 'Alawī scholars of Ḥaḍramawt. In short, it shows Ibn Yahyā's attempt to create another apparatus that could serve as a mechanism for the consolidation of the 'Alawì order in the early nineteenth century. As this is an important document, I translate it in its entirety:

In the name of God most Gracious, most Merciful

Oye who believe! Fear Allahh and be with those who are true [Q. 9:119].

All praise be to Allāh who has made piety [taqwā] as a cause for goodness in this world and the next. God's salutation be upon our master Muhammad, His prophet and His chosen one [muștafāhu], and his elevated 
family and companions. This is a reminder from him who is in need of God's mercy, 'Abdallāh b. 'Umar, to our brethren, the pilgrims [al-hujjāj] residing in Surabaya. [They have] requested [from] me this [reminder]. I have seen their commitment to goodness, their acceptance of the truth, and their assistance in reviving the symbols [sha' $\left.\bar{a}^{\prime} i r\right]$ of the religion. May God further them and us in this, and lead them and us to the best path. Know, $\mathrm{O}$ brothers, that this religion is built on five things:

First, beneficial knowledge, that which introduces you to your Lord and His commandments and prohibitions; and [teaches] abstention from the world, desire for the hereafter, and humility; and discourages you from great sins, jealousy, envy, the desire for respect in the hearts of men, and being removed from the truth. Any knowledge that results in these [spiritual/psychological] states is beneficial knowledge to our condition and possessions. Any knowledge that does not result in what we have described is harmful knowledge. It will not result in anything in the two abodes except disgrace and decay. This [beneficial] knowledge is divided into two: exoteric and esoteric. As for the exoteric: [it is] the knowledge of the law [ figh]. And among its sources are beneficial books for every seeker: Mukhtașar bā faḍl and 'Umdat al-sālik, Mukhtașar al-anwār, and the Minhāj of Imām al-Nawawī. As for the esoteric: the Bidāya al-hidāya of al-Ghazālī, the Nașā' ih al-dīniyya of al-Ḥabīb 'Abdallāh b. 'Alawī al-Ḥaddād, also Risāla al-mu'āwana and Risāla al-mudhākara by the same author, and the Minhāj al-'ābidin of al-Ghazālī.

Second, teaching this knowledge to those who are ignorant, especially his [al-Ghazālī's] selected writings on creeds [al-'aqā'id], the creeds of al-Ghazālī ['aqìda al-ghaz $\bar{a} l \bar{l}$ ], and other abridged treatises on theology such as the matn Jawharat al-tawhìd and Ta' lìm al-'ishrīn al-șifa, without learning the ['Umm] al-barāhìn. As for the last book, it is forbidden to learn it, except for those who have mastered several sciences and have the intelligence and acumen as cautioned by the imams, such as al-Ghazāli and Shaykh Ibn Hajar. They asserted the interdiction of teaching the book to the ordinary people. And the people of this age are ordinary ['awām]. We have mentioned earlier the selections of books in the legal sciences and Sufism. However, the novice should start by learning short and gentle abridged manuals. Of particular importance is the Sullam al-tawfīq of our master and shaykh my maternal uncle 'Abdallāh b. Husayn bin Ṭāhir Bā 'Alawī. Our lover [muḥibbunā] Hajji Muḥammad Hāshim has received the text and we have read it in the Ampel mosque in the presence of our lover Hajji Muhammad Arshad for the most part. ${ }^{63}$ Beware, and beware of occupying oneself with learning any knowledge before learning these short manuals, as these texts have collected a lot of important things that have to be put before the others. 
Third, being truthful to God with sincerity in knowledge and work. Truthful to God's creations in advising, teaching, and instructing them in the good, while prohibiting them from any evil, first with gentleness and soft speech, then with warnings and reminders, and finally with pressure and anger freed from whims and debased passions.

Fourth, leaving any pretension of being a man of knowledge and positioning oneself as a teacher to the ignorant while having no ability on such matters. As it will only bring calamities to the person and his followers. The Prophet, may peace and blessing be upon him and his family, said:

God does not snatch away knowledge from the chests of His servants, but He takes away knowledge by the death of scholars, until, when there are no more scholars remaining, the people take ignorant leaders [as scholars]. And these leaders will be asked [by the people], and they will respond without any knowledge, and they will be misguided and misguide others.

This is narrated by al-Bukhārī and Muslim. There seem to multiply in this land those whom the master of all masters [sayyid al-sādāt] had warned. Many occupy themselves with teaching and giving legal opinion [ fatwō] without the necessary knowledge and mastery, resulting in destruction and catastrophe. Many people are led astray because of them, and the sins that result from such confusions remain continuously and accrue upon them even after their death. And among the disasters of those phony men is their preoccupation with learning great tomes that no one has the ability to master except the 'ulamā' and the erudite sages [jahäbadha al-mubarrizīn], and as a result they make mistakes in comprehending their intended meanings. This has led to the obfuscation of [legal] boundaries. Thus, what is suitable for them is to occupy themselves with simple texts [al-mukhtasarät] so that they can gain some knowledge that will lead them to its conclusions. As such, they will learn what is obligatory for them. And among the calamities is their preoccupation with uncommon problems without any finality. There is no benefit in learning about every situation. They hope that, in discussing such matters in their gatherings, they will be seen as illustrious ' $u l a m \bar{a}$ '. They do not know that the Prophet — may God and peace and blessings be upon him-prohibited [them] from al-aghlütāt [irresolvable questions of doctrine]. So beware, and beware [occupying oneself with] such matters, as it constitutes something without benefits [al-fudül], which only results in anger and discord. It is an approach by which Satan led people to pride and arrogance.

Fifth, inviting [people] to the collective performance of the five obligatory prayers, calling [people] to it in the markets and streets, and 
reverberating the adhān [call to prayer]. Such acts are among the symbols [sha' $\bar{a}^{\prime} i r$ ] of Islam and imān [faith]. Commit to it with perseverance, and invite every Muslim to it. When they gather, teach them interactively, and summarize for them the commandments of the religion. This is because the ordinary people do not benefit from the reading of books. They do not fully understand the arguments and explanations [of these books]. And those who are teaching them [the masses] should approach them in their gatherings, their congregations, their fathers, and their mothers. By doing so, they will revive Islam, and they will gain God's mercy. I ask the almighty God to secure you and us in all goodness, and to protect us from all evils. May God's salutation and blessing be upon our master Muhammad, his family, and his companions. And all praise belongs to God the lord of the two universes.

The tadhkira illustrates another apparatus of the Țarīa 'Alawiyya in this period, that is, scholarly networks consisting of both Haḍramī and local scholars bound by a particular textual canon that incorporated the works of the Bā 'Alawī luminaries. Several important points can be adduced from this document. First, the document clearly shows that Ibn Yahyā was involved in the establishment of intellectual networks tying Bā 'Alawī scholars in Haḍramawt with scholars and students in various parts of the Indonesian archipelago, facilitated also by the Haḍramī merchant network discussed above. The document illustrates how he himself had taught the Sullam al-tawfīq - a Sufi-oriented legal abridgment authored by his maternal uncle and teacher 'Abdallāh b. Husayn bin Țāhir-to his local students. It is likely that Ibn Yahyā was the first person to bring this now popular text to Southeast Asia. ${ }^{64}$ Other texts that he recommended for the Muslims of Java consisted mostly of short legal and Sufi texts written by Haḍramī scholars including Bā Faḍl and al-Haddād. He also criticized the established practice of teaching intricate theological texts like the 'Umm al-barāhīn of al-Sanūsī (d. 895/1490). Ibn Yahyā was therefore involved centrally in the broader transformation of the Islamic curriculum in Java discussed above. In the period when the teachings of the Egyptian Sufi-oriented scholars were gaining ground in the Indonesian archipelago, Ibn Yahyā introduced and disseminated teachings with similar outlooks produced by scholars affiliated with the Taringa 'Alawiyya. By transmitting the works of the Hadramī scholars affiliated with the Țarīqa 'Alawiyya, Ibn Yahyā was not only disseminating the teachings of the tariqa; he was also forming intellectual ties between the Javanese and the Bā 'Alawī Sufi scholars of Haḍramawt, thereby establishing a particular lineage that served to define and structure these networks.

Second, while Ibn Yahyā was actively propagating the teachings of the Țarīqa 'Alawiyya, he apparently did not take oaths of allegiance ('uqda) from the people. Although such formal elements have historically functioned to generate a sense of both vertical and horizontal identity and solidarity within a 
tarīqa, they were not the only mechanism of lineage formation that reproduces a tarīqa. It appears that Ibn Yahyā's approach to the consolidation of the Tarīqa 'Alawiyya focused on the redefinition of the textual canon used by the order's adherents rather than other mechanisms of social incorporation. In this way, curriculum reproduced a particular and recognizable configuration of Sufi doctrine and practice, one with a perceivable pedigree. It also worked as a boundary marker, defining a textual canon for students of Islamic knowledge to the exclusion of other texts. Such a canon together with establishment of an intellectual genealogy through teacher-disciple relationship facilitated the emergence of a particular kind of religious order. These expanding networks and the proliferating educational institutions that they generated functioned to reproduce a coherent body of religious doctrine and practice. As such, they should be identified as one key dimension of the Țarīa 'Alawiyya, insofar as they promoted a distinctly Bā 'Alawī vision of sharī'a-oriented Sufism even when they did not necessarily involve formal elements of tarīqa affiliation like 'uqda or khirqa.

Aside from propagating a new Islamic curriculum, Ibn Yahyā was also involved in the production of simplified legal and theological texts that represented the teachings of the Tarīqa 'Alawiyya. He wrote three short legal manuals on (1) the correct performance (manāsik) of pilgrimage to Mekka, (2) the proper etiquette $(\bar{a} d \bar{a} b)$ for visiting the Prophet's tomb, and (3) the righteous division ( $\operatorname{taf} \bar{i} \bar{q})$ of alms. He also issued legal opinions ( fatwa $)$ on various issues he witnessed in the Malay-Indonesian world, including the performance of dabus, payment of religious officials, alimony, and the marriage between a woman from the Prophet's family and a non-sayyid. ${ }^{65} \mathrm{He}$ argued that imitating the dress and language of the colonial rulers did not constitute unbelief as long as no religious commitment was involved. ${ }^{66} \mathrm{He}$ also composed a short creedal statement during his time in Java on the meaning of the shahäda. That short text, titled 'Aqīda jāmi 'a nāfi'a (The complete beneficial creed), was written so as to facilitate oral recitation and dictation in gatherings - thus reflecting Ibn Yahyā's injunction to teach the masses interactively and mnemonically. In addition, he wrote a short treatise called Risāla fĭ ibtâl bida'munkarāt (Epistle on nullifying reprehensible innovations), comprising a diatribe against what he witnessed as erroneous innovations in local commemorations of the martyrdom of the Prophet's grandson Husayn ('āshüra). In the treatise, he attacked those who demonstrated excessive grief over the event as well as those who were pleased with it. The focus of Ibn Yahyā's criticism is on practices such as wailing, outburst of emotion, self-flagellation, and the tearing of one's garments. ${ }^{67}$

The available historical sources do not permit us to fully discern the success of Ibn Yahyā's attempt to tap into local scholarly networks. In a period marked by the proliferation of competing visions of Islamic knowledge, Ibn Yahyā's vision was certainly not the only one. Ibn Yahyā's curriculum resonated with the broader sharī'a-oriented Islamic visions that were gaining ground during the period, while at the same time incorporating key texts written and lineally 
transmitted by the luminaries of the Tarīqa 'Alawiyya including al-Haddād and Ibn Tāhir. The fact that these texts have been incorporated into the course of study of the traditional pesantren hint at the significant success of Bā 'Alawī scholars including Ibn Yahyā in redefining Islamic curriculum in the region. ${ }^{6}$ However, the fact that texts excluded by Ibn Yahyā, such as al-Sanūsī's 'Umm al-barāhīn, remain central in the curriculum of the pesantren suggests that Ibn Yahyā's aims were not completely realized.

In this chapter, I have partially reconstructed Ibn Yahyā's sojourn to observe the development of the Tarīqa 'Alawiyya in the early nineteenth-century MalayIndonesian world. I have shown that the shifting sociopolitical context enabled the gradual movement of Bā 'Alawī scholars into more established positions. This process was facilitated by the broader rise of sharīa-oriented Sufism transmitted by returning pilgrims and scholars who were exposed to the intellectual currents prevalent in places like the Hijaz. This religious orientation was akin to that promulgated by Bā 'Alawī scholars in Haḍramawt - many of whom studied in the Hijaz, where they were exposed to such currents - and brought to different parts of Southern Asia and East Africa by Hadramī merchants and itinerant scholars. ${ }^{69}$ The convergence of these multiple itineraries resulted in the emergence of a strong vision of sharī'a-oriented Sufism in the region. Within this complex and competitive religious economy, where different Sufi orders and competing visions of Islam vied against each other for societal influence, Haḍramī scholars like Ibn Yahyā attempted to transmit Bā 'Alawī sufism as encapsulated in the Țarīqa 'Alawiyya.

I have shown that the Tarīqa 'Alawiyya in this period was characterized by a strong commitment to the implementation of the sharīa, the spread of simplified legal and theological knowledge, and the promotion of particular forms of political order. As a formal and cultural mechanism of tradition, the tariqa functioned as an order, involving formal, conceptual, and practical apparatuses that reproduced standardized practice and doctrine, maintaining consistency and coherence. The tarīqa enabled its adherents to perceive these intellectual and practice components in the framework of a lineage, that is, as something inherited from previous scholarly generations and thus possessed of a distinct historical identity, differentiated from other tarīqa. In Hadramawt, this sense of identity was shaped through kinship and scholarly networks bound by shared rituals, sacred spaces, and liturgies, solemnized by formal elements including 'uqda, khirqa, and silsila that constituted its discursive boundaries and defined its identity. In the Indonesian archipelago, the Țarīqa 'Alawiyya order retained coherence and distinctiveness within a social ecology markedly different from that of the order's origins in southern Arabia. Three dimensions of the 'Alawiyya order made this possible: the Haḍramī merchant diaspora, royal power in the archipelago, and scholarly networks consisting of both Hadramī and local scholars bound by a particular textual canon that incorporated key Bā 
'Alawī texts. These three dimensions served as mechanisms that promoted a Bā 'Alawī vision of sharī'a-oriented Sufism.

The case of the Tarīqa 'Alawiyya developed in this chapter attests to the value of retaining the term "order" as an analytic category. The term allows the development of comparative perspectives on the organizational infrastructure, conception of affinities, and mechanism of reproduction of diverse religious lineages and formations. Such comparisons can, in turn, highlight the dynamic formal, material, and organizational infrastructures that, together with shifting historical contexts, enable a religious order to function across time and space.

\section{NOTES}

I would like to thank Sayyid Zayd b. 'Abd al-Raḥmān ibn Yahyā, the director of the Markaz al-Noor Research Center, Tarim, Haḍramawt, for providing me with access to the primary sources used in this chapter. Webb Keane, Engseng Ho, Nancy Florida, and Nico Kaptein have all read the chapter in draft and provided helpful comments. Ahmad al-Habsyi helped me with the translation of several difficult passages. Last but not least, I would like to thank R. Michael Feener and Anne Blackburn for their critical reading of the chapter and their valuable feedback.

1. See, for example, Clifford Geertz, Islam Observed: Religious Development in Morocco and Indonesia (New Haven: Yale University Press, 1968); Christine E. Dobbin, Islamic Revivalism in a Changing Peasant Economy: Central Sumatra, 1784-1847 (London: Curzon Press, 1983); and Deliar Noer, The Modernist Muslim Movement in Indonesia, 1900-1942 (Singapore: Oxford University Press, 1973). For more elaborate discussion and critique of this perception, see Michael Laffan, The Makings of Indonesian Islam: Orientalism and the Narration of a Sufi Past (Princeton: Princeton University Press, 2011).

2. Peter G. Riddell, Islam and the Malay-Indonesian World: Transmission and Responses (Singapore: Horizon Books, 2001).

3. M. C. Ricklefs, "The Middle East Connection and Reform and Revival Movements among the Putihan in 19th-Century Java," in Southeast Asia and the Middle East: Islam, Movement, and the Longue Durée, edited by Eric Tagliacozzo (Singapore: NUS Press, 2009), pp. 111-134; Laffan, Makings of Indonesian Islam, pp. 25-64; Christian Pelras, "Religion, Tradition, and the Dynamics of Islamization in South Sulawesi," Indonesia 57 (April 1993): 133-154; A. H. Johns, "Sufism in Southeast Asia: Reflections and Reconsiderations," Journal of Southeast Asian Studies 26.1 (1995): 169-183.

4. The Tarīqa 'Alawiyya originated among the Bā 'Alawī sāda (sing. sayyid), the descendants of the Prophet Muhammad who had long settled in the Hadramawt valley of southern Yemen. Initially articulated in the thirteenth century by Muhammad b. 'Alī Bā 'Alawī (d. 653/1255), also known as al-Faqị al-Muqaddam (the preeminent jurist), The țarīqa combines two spiritual genealogies (silsila): that of the Prophet's family (ahl al-bayt) transmitted through the Prophet's descendants and that of the renowned sufi master of the Maghrib, Shu'ayb Abū Madyan (d. 594/1198). The țarīqa provides a particular model of spiritual wayfaring, a set of sharīa-oriented guidelines for those climbing the ladder of spiritual stations (maqāmāt). Its practical underpinning is articulated in the doctrine of emulating the 
Prophet inwardly and outwardly by following the footsteps of his family and descendants, in particular the Bā 'Alawī. See Ismail Fajrie Alatas, "[al-]'Alāwiyya (in Ḥaḍramawt)," in Encyclopaedia of Islam, vol. 3, edited by Kate Fleet, Gudrun Krämer, Denis Matringe, John Nawas, and Everett Rowson (Brill Online, 2014), http://referenceworks.brillonline .com/entries/encyclopaedia-of-islam-3/al-ala-wiyya-in-h-ad-ramawt-COM_23830, accessed August 6, 2014.

5. Ulrike Freitag, Indian Ocean Migrants and State Formation in Hadhramaut (Leiden: Brill, 2003).

6. Nile Green, Sufism: A Global History (Chichester: Wiley-Blackwell, 2012), p. 81.

7. Ibid.

8. See Anne Blackburn and Michael Feener's introduction to this volume in Chapter 1. See also R. Michael Feener, "Issues and Ideologies in the Study of Regional Muslim Cultures," in Islamic Connections: Muslim Societies in South and Southeast Asia, edited by R. Michael Feener and Terenjit Sevea (Singapore: ISEAS Press, 2009), pp. xiii-xxiv; Anne M. Blackburn, Buddhist Learning and Textual Practice in Eighteenth-Century Lankan Monastic Culture (Princeton: Princeton University Press, 2001).

9. See Anne Blackburn and Michael Feener's introduction to this volume in Chapter 1.

10. For a prominent example, see, J. S. Trimingham, The Sufi Orders in Islam (Oxford: Clarendon Press, 1971).

11. Shahzad Bashir, Sufi Bodies: Religion and Society in Medieval Islam (New York: Columbia University Press, 2011), p. 11.

12. Danièle Hervieu-Léger, Religion as a Chain of Memory (New Brunswick: Rutgers University Press, 2000), pp. 151-152.

13. Ibid., pp. 106-107.

14. 'Abd al-Raḥmān b. 'Ubaydillāh al-Saqqāf, Idām al-qūt fī dhikr buldān ḥaḍramawt (Sana'a: Dār al-minhaj 2005), p. 824.

15. 'Aqīl b. 'Abdallāh ibn Yahyā, Tadhkira al-ahya' bi-manāqib sayyidinā wa imaminā al-sayyid al-sharîf 'abdallāh $b$. 'umar bin yahyā bā 'alawī, edited by Zayd b. 'Abd al-Raḥmān ibn Yahyā (privately printed, n.d.), p. 32.

16. Abdallāh b. Sa'ad ibn Sumayr was the father of the jurist Sālim bin Sumayr (d. 1270/1853), the author of the popular text on jurisprudence Safinat al-najāh (Arc of salvation) and a close friend of Ibn Yahyā. Today, the text is still in use as an elementary text in pesantren (Islamic boarding schools) throughout Java.

17. The summary of Ibn Yahyā̄'s life is based on his manāqib (hagiography), titled Tadhkira al-ahyā' bi-manāqib sayyidinā wa imaminā al-sayyid al-sharīf 'Abdallāh bin 'Umar $i b n$ Yahya $\bar{a} \bar{a}$ 'Alawi (Reminder for the living with the hagiography of our master and our imam the sayyid and sharîf 'Abdallāh bin 'Umar ibn Yahyā Bā 'Alawī), written by his son 'Aqīl (d. 1294/1877). The text summarizes the birth, upbringing, education, and teachers of Ibn Yahyā. It also illustrates his many virtues and noble characters together with several anecdotes of miracles that he performed. Aqīl concludes the manāqib with a detailed exposition of Ibn Yahyā's chain of initiation into the tarīqa together with the chain of his cloak of investiture (khirqā). I thank Sayyid Zayd b. 'Abd al-Raḥmān ibn Yahyā for sending me a typescript of the unpublished manāqib together with a collection of Ibn Yahyā's discourse, correspondence, and poems that he edited and compiled from various manuscripts in Ḥaḍramawt. For a shorter version of Ibn Yahyā's biography as well as the biographies of his descendants, see Muḥammad 'Alawī b. Aḥmad ibn Yaḥyā al-'Alawī al-Ḥaḍramī, Sharaf 
al-muhayyā fì tarājim 'adad min 'ulamā' wa udabā' àl yahyā (Tarīm: Tārīm lidirāsāt wa alnashr, 2007), pp. 25-48.

18. Alexander Knysh, "A Tale of Two Poets: Sufism in Yemen during the Ottoman Epoch," in Le Soufisme à l' époque Ottomane, edited by Rachida Chih and Catherine Mayeur-Jaouen (Cairo: Institut française d'archéologie orientale, 2010), p. 338.

19. This was the ribāt (pl. arbița) in Say'ūn founded by the charismatic Bā 'Alawī scholar and poet 'Alī b. Muḥammad al-Ḥabashī (d. 1914). See Freitag, Indian Ocean Migrants, pp. $278-281$.

20. Engseng Ho, The Graves of Tarim: Genealogy and Mobility across the Indian Ocean (Berkeley: University of California Press, 2006), pp. 43-44.

21. Knysh, "Tale of Two Poets," p. 338.

22. Ibid., p. 339.

23. 'Aydarūs b. 'Umar al-Ḥabashī, 'Iqd al-yawāqīt al-jawhariyya wa simt al-'ayn al-dhahabiyya bi-dhikr tarìq al-sādat al-'alawiyya (Jakarta: privately printed, n.d)., vol. 1, p. 127.

24. For further elaborations on these formal elements of a tarīqa, see Jamal J. Elias, "The Sufi Robe (khirqa) as a Vehicle of Spiritual Authority," in Robes and Honor: The Medieval World of Investiture, edited by S. Gordon, (New York: St. Martin's Press, 2000), pp. 275-289.

25. Ismail Fajrie Alatas, "Abdallāh b. 'Alawī al-Ḥaddād," Encyclopaedia of Islam, vol. 3, edited by Fleet, Krämer, Matringe, Nawas, and Rowson, http://www.paulyonline.brill.nl/entries /encyclopaedia-of-islam-3/abdalla-h-b-alawi-al-h-adda-d-COM_24682, accessed August 6, 2014.

26. Green, Sufism, p. 175. For this development in the Ottoman Empire, see Cemal Kafadar, Between Two Worlds: The Construction of the Ottoman State (Berkeley: University of California Press, 1995). For similar development in the Safavid Empire, see Kathryn Babayan, "The Safavid Synthesis: From Qizilbash Islam to Imamite Shi ism," Iranian Studies 27.1-4 (1994): 135-161. For the Mughal Empire, see Muzaffar Alam, "The Mughals, the Sufi Shaikhs and the Formation of the Akbari Dispensation," Modern Asian Studies 43.1 (2009): $135-174$.

27. For instance, the Nayl al-watar, a biographical dictionary of the Yemeni scholars of the thirteenth Islamic century, mentions Ibn Yahyā as a scholar and jurist without specifying his role as a shaykh of the Țarīqa 'Alawiyya. See Muḥammad Zubāra, Nayl al-wațar min tarājim rijāl al-Yaman fi-l-qarn at-thālith 'ashr (Sanaa: al-Mațba'a al-Salafĩya, 1931), pp. 91-92.

28. Ibn Yahyā, Tadhkira al-ahya', pp. 39-40.

29. For detailed accounts on this expanding world of Ḥadramī diaspora in Southeast Asia, see Freitag, Indian Ocean Migrants, chap. 1; Ho, Graves of Tarim, chap. 6.

30. Ho, Graves of Tarim, chap. 6; Omar Farouk Bajunied, "Arabs and the Nation-State in Southeast Asia," al-Mahjar 2.1 (1997): 4-6.

31. R. Michael Feener, "New Networks and New Knowledge: Migration, Communication, and the Refiguration of Muslim Community in the Nineteenth and Early Twentieth Centuries," in The New Cambridge History of Islam, vol. 6, edited by Robert Hefner (Cambridge, UK: Cambridge University Press, 2010), pp. 39-68; James L. Gelvin and Nile Green, "Introduction," in Global Muslims in the Age of Steam and Print, edited by James L. Gelvin and Nile Green (Berkeley: University of California Press, 2014), pp. 1-24.

32. William Gervase Clarence-Smith, "Entrepreneurial Strategies of Hadhrami Arabs in Southeast Asia, c. 1750s-1950s," in The Hadhrami Diaspora in Southeast Asia: Identity 
Maintenance or Assimilation? edited by Ahmed Ibrahim Abushouk and Hassan Ahmed Ibrahim (Leiden: Brill, 2009), pp. 139-140.

33. Peter Carey, The Power of Prophecy: Prince Dipanagara and the End of an Old Order in Java, 1758-1855 (Leiden: KITLV Press, 2008).

34. Robert Van Niel, "Measurement of Change under the Cultivations System in Java, 1837-1851," Indonesia 14 (Oct. 1972): 89-109.

35. The term priyayi originally referred to the younger siblings of the king. Subsequently it came to denote the bureaucratic or administrative elite of Java. See Heather Sutherland, The Making of a Bureaucratic Elite (Singapore: Heinemann, 1979).

36. Eric Tagliacozzo, The Longest Journey: Southeast Asians and the Pilgrimage to Mekka (Oxford: Oxford University Press, 2013), pp. 63-82.

37. Ricklefs, "Middle East Connection and Reform," p. 114.

38. The term "religious marketplace" is Nile Green's. See Nile Green, Bombay Islam: The Religious Economy of the West Indian Ocean, 1840-1915 (Cambridge, UK: Cambridge University Press, 2011), p. 47.

39. Laffan identifies the role of traveling scholars like 'Abd al-Samad al-Palimbānī (d. 1789) and Muhammad Arshad al-Banjarī (d. 1812), both of whom studied with the Medinese shaykh Muhammad Samman (d. 1776), as the forerunners of this shift. Samman cultivated links with the Cairene tradition of Sufism that emphasized the writings of the medieval Sufi theologian and jurist Abū Ḥāmid al-Ghazālī (d. 1111) and his Egyptian commentators like 'Abd al-Wahhāb al-Sha' rānī (d. 1565). See Laffan, Makings of Indonesian Islam, p. 33. On al-Sha'rān̄̄'s role in the reconfiguration of Sufi thought, see Richard J. A. McGregor, "Notes on the Transmission of Mystical Philosophy: Ibn 'Arabī According to 'Abd al-Wahhāb al-Sha rān̄̄," in Reason and Inspiration in Islam, edited by Todd Lawson (London: I. B. Tauris, 2005), pp. 380-394.

40. This, however, does not mean that Muslim scholars were not active in the countryside before the Java War. Evidence suggests that they were already spread across the countryside and establishing pesantren, like the famous pesantren of Tegalsari. Sources like the 1815 Serat Centhini suggest that the royal court, the countryside, and Muslim scholars were in dialogue. Similarly, one should not assume that the royal court was not actively involved in the pesantren of the countryside. Nancy Florida has shown how several key court luminaries, particularly literati and court poets—including the veritable literati family of Yasadipura-were educated in rural pesantren. In addition, when Chinese rebels overran the court of Pakubuwana II in 1742, the king fled the royal court and took shelter with the Islamic scholar Kyai Ageng Imam Besari of Panaraga, East Java. In sum, available historical sources suggest that (1) Muslim scholars were already active in the countryside before the Java War and (2) luminaries from the royal court were not imprisoned behind palace walls. Rather, there seems to have been circulation of people and ideas between rural Islamic establishments and the royal court. Nevertheless, the end of the Java War did result in the proliferation of new pesantren across Java. See Nancy K. Florida, "Writing Traditions in Colonial Java: The Question of Islam," in Cultures of Scholarship, edited by S. C. Humphreys (Ann Arbor: University of Michigan Press, 1997), pp. 187-217. See also Florida's contribution in this volume.

41. M. C. Ricklefs, Polarizing Javanese Society: Islamic and other Visions, c. 1830-1930 (Singapore: NUS Press, 2007), pp. 52-53.

42. Peter J. M. Nas and Pratiwo, "Java and De Groote Postweg, La Grande Route, the Great Mail Road, Jalan Raya Pos," Bijdragen tot de Taal-, Land-en Volkenkunde 158.4 
(2002): 707-725; Pramoedya Ananta Toer, Jalan Raya Pos, Jalan Daendels (Jakarta: Lentera Dipantara, 2005).

43. Ricklefs, Polarizing Javanese Society, p. 81.

44. 'Abd al-Qādir b. 'Abd al-Raḥmān al-Junayd, al-'Uqūd al-'Asjadiyya fī nashr manāqib ba'dh afrād al-usra al-junaydiyya (Singapore: al-Mahdudah, 1994), pp. 167-168, 178-180; Ho, Graves of Tarim, pp. 82-83.

45. Al-Saqqāf, Idām al-qūt, pp. 601-602; L. W. C. van den Berg, Hadramaut dan Koloni Arab di Nusantara, translated by Rahayu Hidayat (Jakarta: INIS, [1886] 1989), p. 106.

46. Laffan, Makings of Indonesian Islam, p. 48; Martin van Bruinessen, Kitab Kuning, Pesantren dan Tarekat (Bandung: Mizan, 1995), p. 122.

47. Azyumardi Azra, Islam Nusantara: Jaringan Global dan Lokal (Bandung: Mizan, 2002), p. 141; William R. Roff, "The Malayo-Muslim World of Singapore at the Close of the Nineteenth Century," Journal of Asian Studies 24 (1964): 75-90; Michael Laffan, "The New Turn to Mekka: Snapshots of Arabic Printing and Sufi Networks in Late 19th Century Java," Revue des mondes musulmans et de la Méditerranée 124 (2008): 113-131.

48. One report from 1848 suggests that the Arab population in the coastal region was not big but was large enough to have significant impacts. In Tegal, for instance, out of a total population of 317,446, there were at least 2,275 Arabs and other Asian Muslims. See Ricklefs, Polarizing Javanese Society, p. 81.

49. Ibn Yaḥyā, Tadhkira al-ahya', pp. 376-381.

50. Ibid., p. 378. For al-Saqqāf, see Ho, Graves of Tarim, pp. 43-44.

51. Ibn Yaḥyā, Tadhkira al-ahya', p. 325.

52. Azyumardi Azra, The Origins of Islamic Reformism in Southeast Asia: Networks of Malay-Indonesian and Middle Eastern 'Ulama' in the Seventeenth and Eighteenth Centuries (Honolulu: University of Hawai'i Press, 2004); R. S. O'Fahey, “'Small World': Neo-Sufi Interconnexions between the Maghrib, the Hijaz and Southeast Asia," in The Transmission of Learning in Islamic Africa, edited by Scott S. Reese (Leiden: Brill, 2004), pp. 274-288.

53. Arabic letters circulated around the Indonesian archipelago and beyond between rulers who had scribes and translators for such correspondence. Writing a few decades later, the Dutch colonial official L. W. C. van den Berg described how the princes of the Madurese royal family were solidly educated in Arabic. An Arabic speaker himself, van den Berg was impressed by the Arabic proficiency of the Madurese princes as well as the Arabic holdings of the royal libraries. Such a conscious effort to be more attuned to the wider Muslim world had opened up lucrative positions for Haḍramī scholars as Arabic instructors to the Madurese royal families. See van den Berg, Hadramaut dan Koloni Arab, p. 108.

54. Claiming descent from the last king of Majapahit, the Tjakraningrat family had ruled Madura since the sixteenth century. In the seventeenth century, they were appointed to govern Madura under the suzerainty of the Mataram Sultanate. Following the Javanese-Chinese War of 1741-1743, Tjakraningrat IV took the opportunity to shake off his vassal obligation to Mataram with the help of the Dutch East India Company (VOC). Recognizing the importance of the alliance, the VOC decided in 1762 to raise the title of Tjakradiningrat $\mathrm{V}$ to Panembahan Tjakraadi-ningrat V. During the reign of Tjakradiningrat VII (1780-1815), the kingdom began to send troops to support the colonial authority on its military campaigns, a practice that continued until the Java War. In 1816, the sultan signed a contract with the Dutch relieving the sultanate of taxation in return for the supply of military manpower. In recognition of their military role, the Dutch reorganized the Madurese troops into a permanent armed corps, the barisan, consisting 
of infantry, cavalry, and artillery. Despite the general commitment to reducing the power of the sultan, the Dutch continued to confer various decorations and privileges on the Madurese ruler. By the 1820s, the Sultanate of Madura was referred to not as zelf-bestuurders (self-administrators) but as onafhankelijk bondgenoten (independent allies). The honors, however, were not bestowed purely out of generosity, as successive Dutch authorities wished to prevent Madurese defections in the tumultuous first decades of the nineteenth century. In 1808, Tjakraadiningrat VII elevated his title and prestige to become the first sultan of Madura. His son, 'Abd al-Qādir, succeeded his father as Sultan Tjakraadiningrat II. See Kuntowijoyo, Perubahan sosial dalam masyarakat agraris Madura, 1850-1940 (Jogjakarta: Matabangsa, 2002); Heather Sutherland, "Notes on Java's Regent Families: Part II," Indonesia 17 (1974): 1-42.

55. For an extended discussion of Islamic epistolary tradition, see Jaakko Hämeen-Anttila, "The Essay and Debate (Al-Risāla and al-Munāzara)," in Arabic Literature in the Post-Classical Period, edited by Roger Allen and D. S. Richards (Cambridge, UK: Cambridge University Press, 2006,) pp. 134-144; Samer Akkach, Letters of a Sufi Scholar: The Correspondence of 'Abd al-Ghanī al-Nābulusī (1641-1731) (Leiden: Brill 2010).

56. Ibn Yaḥyā, Tadhkira al-ahya', p. 209.

57. Ibid.

58. Ibid., p. 210.

59. Ibid.

60. Van den Berg, Hadramaut dan Koloni Arab, p. 109.

61. Laffan, Makings of Indonesian Islam, pp. 25-39.

62. The original copy of this manuscript is kept in the Markaz al-Noor archive in Tarim, Haḍramawt. I thank Zayd bin Yahya for providing me with a copy of this precious document.

63. In Sufi knowledge culture, the term muhibbin (lovers) is usually contrasted with the term murīdin (disciples). The former refers to the "untutored enthusiasts" of a Sufi master, whereas the latter denotes the "formally initiated disciples." See Vincent J. Cornell, Realm of the Saint: Power and Authority in Moroccan Sufism (Austin: University of Texas Press, 1998), p. 197. In Hadramawt, the term muhibbīn is also used to refer to the non-Bā 'Alawī followers and devotees of the Bā 'Alawī sayyids.

64. Together with the Safīnāt al-najāh of Ibn Sumayr (see above), the Sullam al-tawfīq is one of the two most recited and taught elementary legal abridgments in Java to the present day. Both texts are recited not only in the pesantren, but also in neighborhood and village prayer halls (Jv. langgar).

65. Nico J. G. Kaptein, Islam, Colonialism and the Modern Age in the Netherlands East Indies: A Biography of Sayyid 'Uthman (1822-1914) (Leiden: Brill, 2014), p. 66. Dabus is a dance with roots in Sufi tradition common in several places in Sumatra, Malaya, and Banten. The word dabus in Arabic means "iron awl with a handle." The Sufi dance was probably called dabus because it was performed with sharply pointed iron awls. After reaching a trancelike state, the dancers stab their bodies and arms with the awls without physically injuring themselves. See Jacob Vredenbregt, "Dabus in West Java," Bijdragen tot de Taal-, Landen Volkunde 129.2/3 (1973): 302-320; Martin van Bruinessen, "Shari'a Court, Tarekat and Pesantren: Religious Institutions in the Banten Sultanate," Archipel 50 (1995): 165-199.

66. The issue of Muslims adopting non-Muslim dress has long been a subject of intense debate among Muslim scholars. Central to this contention is the definition of tashabbuh (imitation) as stated in a saying attributed to the Prophet Muhammad: "whosoever imitates a particular group, he is from among them" (man tashabbaha bi qawmin fā huwā minhum). Some 
scholars argue that adopting European dress constitutes tashabbuh of non-Muslims and can lead to apostasy. The term tashabbuh refers to the adoption of customs and habits that are deemed to be peculiar to a particular group. According to this perspective, the adoption of dietary and sartorial habit constitutes tashabbuh. Learning a foreign language, however, does not constitute tashabbuh. Ibn Yahyā's opinion regarding the imitation of European fashion and language is thus more lenient than most scholars'. In 1904, another Bà 'Alawī scholar from the same family as Ibn Yahyā, who also happened to be one of his students, Sayyid 'Uthmān (d. 1914), authored a small brochure forbidding Muslims from imitating European dress, as by wearing a cravat or necktie. See Kaptein, Islam, Colonialism and the Modern Age, pp. 66, 137-138.

67. Ibn Yahyā, Tadhkira al-ahya', pp. 299-304.

68. By the time L. W. C. van den Berg had compiled a list of fifty texts studied in the pesantren of Java and Madura in 1887, a clear and consistent program of study was already discernible, albeit with slight variations from one institution to the next. Van den Berg's survey demonstrates that the texts recommended by Ibn Yahyā had been incorporated into the established curriculum. See L. W. C. van den Berg, "Her Mohammedaansche Godsdienstonderwijs op Java en Madoera: En de Daarbij Gebruikte Arabische Boeken," Tijdschrift voor Indische Taal-, Land-en Volkenkunde, 31 (1887): 1-38. See also Bruinessen, Kitab Kuning, Pesantren dan Tarekat, pp. 112-171.

69. For the activism of Bā 'Alawī scholars in East Africa, see Anne K. Bang, Islamic Sufi Networks in the Western Indian Ocean, c. 1880-1940 (Leiden: Brill, 2014). For their religious activism in South Asia, see Muḥammad Abū Bakr 'Abdallāh Bā Dhīb, Ishāmāt 'ulamā hadramawt fī nashr al-islām wa 'ulūmihi fì al-hind (Amman: Dār al-fatḥ lil-dirāsāt wa-lnashr, 2014). 


\title{
THE ITINERARIES OF "SĪHAḶA MONK" SĀRALANंKĀ
}

\author{
Buddhist Interactions in Eighteenth- \\ Century Southern Asia
}

\author{
ALEXEY KIRICHENKO
}

Since the early stages of academic work on Buddhist traditions for which Pāli is a canonical language, the task of analyzing Buddhist monastic orders in specific historical contexts has been a difficult one. Vinaya regulations of monastic behavior and observances that form part of the authoritative collections of foundational Buddhist teachings (tipitaka) essentially see all ordained practitioners who follow the doctrine and discipline of the Buddha as an aggregate body of monastics (saigha). Empirical studies, in contrast, identify a multitude of local communities with their respective ordination lineages, practical canons, interpretations of discipline, and so on. As testified by the historical evidence, monastics moved as individuals or in groups within the wider Buddhist world, thus transcending the divide between the two scales of macro- and micro-communities. Yet, for scholars, a significant challenge lies in understanding how these movements worked. That is, how did persons identified generally with the wider Buddhist monastic saingha also function within and across specific local Buddhist and monastic communities? How did local monastic communities interact with each other? Were there impediments to monastic mobility from one area or country to another?

For earlier generations of scholars, it appears that the very notion of macrocommunity, an ideal sangha defined in the Vinaya, created an expectation that encounters between local varieties or branches of the Buddhist monastic order oriented toward a shared Pāli-language tipitaka would be guided by mutual recognition. This perception was strengthened by several known instances of the reintroduction of higher ordination (upasampadā) from Lankā to Southeast Asia and vice versa in the second millennium. Thus, in his survey of Pāli literature, K. R. Norman noted that, owing to such imports of upasampadā and the transmission of manuscripts, "the traditions of each country have become 
to some extent interwoven."' Addressing Burma's contacts with Lañkā, U Bokay, Kanai Lal Hazra, and Tilman Frasch laid much emphasis on the argument that both countries relied on each other for monastic ordination and maintained what are rather vaguely called "institutional linkages," "strong bonds," and "close religious ties." 2 Some scholars, such as Niharranjan Ray, Charles Godakumbura, Hazra, and Emmanuel Guillon, interpreted the limited data on monastic reordinations as evidence for the expansion of one subregional sangha — "the Sinhalese form of Buddhism," or "Mahāvihāra Buddhism"- to Burma and other parts of mainland Southeast Asia after the twelfth century, overtaking other local monastic institutions. ${ }^{3}$

However, more recent studies discussing Buddhist monastic contacts in Southern Asia are much more cautious in their conclusions. In particular, Peter Skilling and Anne Blackburn have argued that monastic lineages that arose as a result of imported ordination invoked their origin as a way to prove ritual purity and efficacy but developed their own independent identities, quite distinct from the monastic communities as practiced and organized at the geographic source of the ordination. ${ }^{4}$

The present chapter focuses on new evidence on transregional ordination lineages in early modern Southern Asia. This new evidence generally supports arguments for independent development (such as those by Skilling and Blackburn), showing that importation of an ordination - an act of using transregional monastic intermediaries to enable local initiators of reordination to start a new monastic lineage - did not necessarily entail the transplantation of the lineage of the intermediary or any features associated with that lineage in its location of origin. Though the transplantation of such external features as forms of dress, monastic administration, educational practice, and textual preferences did occur between monastic communities in Burma, Laṅkā, and Thailand since the late nineteenth century, it would be wrong to assume that such transfers were the norm in the earlier periods as well.

Moreover, movements of Buddhist itinerants between local communities within a wider Buddhist world did not necessarily forge lasting operational ties and networks between these communities. The case presented and analyzed in this chapter suggests that clear distinctions should always be made between different types of transmission and mobility among Buddhists. At one end of the spectrum of possibilities, we find sporadic transmission of objects (such as relics, images, and manuscripts) and persons. Another possibility was religious networking involving more regular communication between different nodes. This communication might include a relatively regular use of imported religious specialists for ritual or prestige purposes without a larger expansion of orders. At the other end of the spectrum, we find lasting forms of transfer, resulting in the spread of common practices and social structures. Though all of these possibilities are found at different points in time and space, one has to be very specific in analyzing the extent of historical monastic interactions. 
This chapter follows the definition of Southern Asia as suggested by the editors of the present volume. At the same time, it recognizes that the introduction of such a term is unlikely to exhaust the need for refining historical geographic terminology, since important economic and cultural links existed not only between South and Southeast Asia but between Southeast and East Asia and elsewhere. During the period in question here, long-distance mobility at the scale of the entirety of Southern Asia was extraordinary or even exceptional. Therefore, this space might be called a macroregion made of many smaller suband microregions (at the scale of individual polities, principalities, and other historical units recognized by Southern Asian peoples and cultures). In this way, the movements of religious itinerants within this macroregion transcended geographic and polity boundaries. It would perhaps have been recognized as transregional by eighteenth-century Burmese, Thai, or Sinhalese had their conceptual vocabulary included such a term.

My general argument and analysis of mobility of Buddhist itinerants in early modern Southern Asia derives from a case study in the eighteenth-century revival of Buddhist contacts between Lankkā, Siam, and Burma. It is centered on the monk Sāralañkā, a Tai from Tenasserim who was involved in one of the Siamese missions to Kandy in the 1750s that led to the establishment of Siyam Nikāya, one of the three currently major Lankan monastic fraternities. Later on, Sāralañkā traveled to Upper Burma and resided there for more than a decade. During that time, he gave at least four or five testimonies on his travels, copies of which remained in circulation in Burma until the late nineteenth century.

Following the travels of an individual actor involved in the transmission of monastic ordination offers a rare perspective on the institutionalization of a Buddhist lineage. Sāralañkā's testimonies and the alterations to his narratives made over time provide a striking view of the contingencies accompanying the movement of a Buddhist monk from life within a particular local community to functioning within the wider space of Southern Asia, encompassing several sub- and microregions and cultures. The chapter draws attention to Sāralañkā's interstitiality as a social actor and argues that it was hardly unusual or insignificant in its time. As the imperial cultures of the region were exclusivist and conceptually incompatible in certain aspects, the malleability of mobile figures such as Sāralañkā proved a valuable asset, allowing royal courts to communicate — and sometimes cooperate — across the greater Buddhist world.

\section{IMPORTING MONASTIC ORDINATION AND THE ROLE OF THE "MISSIONARY"}

Sāralañkā's travel to Lañkā occurred as a result of attempts made by the royal court at Kandy to reestablish a formally ordained (through upasampadā) monastic community on the island..$^{5}$ For reasons that are not clear, from the sixteenth century onwards standard forms of Buddhist monasticism yielded to specific 
types of nonordained monastic practice. A reformist religious movement led by Välivița Saranamkara (1698-1778) managed to get the support of the Kandyan court, sending off envoys to Southeast Asia with the help of the Dutch East India Company (VOC). In 1753, a monastic mission sent from Ayutthaya was enthusiastically received by Kandyan king Kīrti Śrī Rājasiṃha (r. 1747-1782) and ordained a large number of monks and novices in different parts of the island. Another mission arrived three years later and might have been followed by a third one in the late 1750s. The interchange of missions between Siam and Lañkā then stopped until the early nineteenth century.

The reestablishment of monastic ordination and the revival of centralized Buddhist ecclesiastical structure achieved by Saraṇamkara and his associates had a lasting impact on Sinhalese Buddhism, monastic education, and textual practices. ${ }^{6}$ However, little, if any, of this success could be ascribed to Ayutthayan bhikkhus (fully ordained monks) who were invited as officiators to Lañkā. Besides several names and a few celebratory but vague remarks, Sinhalese and Thai sources mention almost nothing about them. Accounts of Kandyan envoys provide limited information about missionaries that were sent to Lankāa, concentrating instead on details of the journey, description of the Siamese court, local ceremonies they witnessed, and sacred sites near Ayutthaya. ${ }^{7}$ The Mahāvamsa, a major Lankan chronicle first composed in the early sixth century and supplemented serially, including by a prominent Siyam Nikāya monk in the 1780 s, is equally silent on the lineage of Siamese missionaries, as noted by Anne Blackburn. ${ }^{8}$

In a coincidence that is quite telling, a similar lack of interest in profiling the source of imported ordination is also evident in the case of Northern Thai monastic histories tracing the ordination of Thai monks on Lankā in the fifteenth century. ${ }^{9}$ In the same way, the Amarapura Nikāya, a competitor to Siyam Nikāya established as a result of bringing new ordination from Burma to coastal areas of Lankāa between 1800 and 1813, cherished little memory of Aggasāra and other Burmese monks who officiated at the ordinations carried out after the return of Am̆bagahapițiye Ñānavimala, the first of Sinhalese novices ordained in Burma. ${ }^{10}$ In fact, it is only from the second half of the nineteenth century that a substantial traffic of ideas, arguments, and modes of practice as well as lasting forms of communication are traceable between Sinhalese and Southeast Asian monks. ${ }^{11}$

In terms of the distinctions introduced above, the emergence of Siyam Nikāya should be understood as a case in which a transfer of ordination within the Southern Asian Buddhist world occurred without the transplantation of monastic order, lineage, or external forms of monasticism. Blackburn's work shows that the success of a new community was secured by its ability to position itself as perpetuating "pre-existing local understandings of prestigious monasticism." 12 She notes a high degree of selectivity by early leaders of Siyam Nikāya with respect to Siamese Buddhist practices. According to Blackburn, in 
almost every case, when Siyam Nikāya monks had a choice to make between local ritual forms and expressions (styles of chanting, curriculum, administrative models, and so on) and forms and arrangements recommended or personified by Ayutthaya monks, they displayed a clear preference for local Buddhist traditions. ${ }^{13}$ Although manuscripts were brought from Ayutthaya and entered Siyam Nikāya collections, there is no evidence that these texts were used in Kandy according to systems of education and practice characteristic of Buddhist monastic orders at Ayutthaya. ${ }^{14}$

Although the Ayutthayan missions to Kandy appear not to have expanded Ayutthayan Buddhist monastic orders to the island, the testimonies of Sāralanikā, a monk involved in this transmission of ordination offer a rare opportunity to examine the personality and subjectivity of historical "missionaries." They also offer insights into the context in which Buddhist mobility in historical Southern Asia occurred and the extent of religious networking that such mobility could support. Moreover, since Sāralañkā was not a central actor in Ayutthayan missions (and his testimonies result only from his unexpected subsequent relocation to Upper Burma), his perspective on the Ayutthayan connections to Kandy do not reflect the polemical needs of the Ayutthayan or the Kandyan saingha but, rather, a more distant perspective on the establishment of Siyam Nikāya in particular and the workings of religious travel in eighteenth-century Southern Asia more generally.

\section{SĀRALAN̉KĀ'S TESTIMONIES AND CAREER}

Of several testimonies taken during Sāralan̉kā's residence in Upper Burma, at least two survive. The first was recorded in 1767 by Ranma Thiri Kyawhtin, officer in charge of the Mahamingalabon royal manuscript library, a service obligation for which he was rewarded with revenues accruing from the village of Khadaw. ${ }^{15}$ The record appears to have been made soon after Sāralanikā's arrival in Upper Burma. A copy of this testimony survives in the Zetawun monastery in Monywe village. It is undated, but, judging by the manuscript's layout and handwriting, it seems to be nearly contemporary with the original record. The second available testimony was taken before Sāralan̉kā's return to Tenasserim. The document is dated December 1787, but the date appears to be wrong (see notes 18 and 29 below). ${ }^{16}$ An undated copy of this document is now kept in the Universities' Central Library in Yangon, and its provenance cannot be ascertained. ${ }^{17}$ The manuscript can be assigned a tentative date falling between the 1850 s and the early 1900 s.

All data on Sāralañkā come solely from these testimonies that are not fully reliable. Sāralan̉kā himself gave conflicting information as he was adapting his biography over the time of his stay in Burma. In addition, there seem to be scribal errors in the manuscripts. Therefore, working out a precise chronology of Sāralaṅkā's life and travels poses difficulties. ${ }^{18}$ Since the purpose of this chapter 
is to explore the case of Sāralañkā in relation to Buddhist networking and the importation of monastic ordinations, I leave a detailed analysis of testimonies and their chronology for another essay, while providing in this chapter a synoptic reconstruction of Sāralañkā's career.

Sāralañkā was likely born in the late 1720 s or 1730 s. According to the 1767 testimony, his place of birth was Pin-o village near Tenasserim. ${ }^{19}$ Between the early seventeenth century and 1760, Tenasserim functioned as one of the principal ports controlled by Ayutthaya, so Sāralañkā originated from a key spot on the Siamese maritime frontier. ${ }^{20}$ In his testimony providing an ethnic identification in accordance with Burmese usage, Sāralañkā described himself as Taninthayi Shan (Tai from Tenasserim). ${ }^{21}$ The Ayutthayan polity granted his father the revenues accruing from a village of Bakaung near Tenasserim, which suggests that he had been a minor official. ${ }^{22}$ Sāralañkā grew up at the court of Ayutthaya, for he was summoned there (as he stated in 1767) or moved there accompanying a son of a Mottama (Martaban) princess who became an Ayutthayan queen (as he testified in the 1780s). ${ }^{23}$

When this prince became a novice at an Ayutthayan royal temple (unidentified in the testimonies), Sāralañkā followed suit and later became a monk at the same temple. ${ }^{24}$ In 1753 and 1756, when two missions were sent to reestablish ordination on Lan̉kā, Sāralañkā's monastic preceptor was chosen to head the second one. Sāralan̉kā accompanied him to Lañkā, lived there for a few years, and then returned to Ayutthaya (in 1764, it appears) for a brief period. Later, he moved back to Tenasserim, perhaps in 1765. At that time, Tenasserim fell from Siamese control. In early 1760, the town was captured by the Burmese king Alaungmintaya (r. 1752-1760). After brief restoration of Siamese rule over the Tenasserim coast in the early 1760s, in 1764 a new Burmese king, Hsinbyushin (r. 1763-1776), appointed officials to three major ports to the north of Tenasserim, and, in the summer of 1765, Burmese troops under the command of Min Mahanawyahta arrived at Dawe (Tavoy) and secured the coastline. ${ }^{25}$

As the arrival of troops under Min Mahanawyahta to Tavoy is mentioned in the "1787" testimony, Sāralañkā seems to have returned to Tenasserim near this time. He attempted to hide in the forest but was captured by Burmese soldiers, perhaps in 1765 or in early 1766. First, he was accommodated at Mergui. However, owing to the scarcity of resources there, he was sent on to Tavoy, which seems to have functioned as Burmese headquarters on the coast. There, Sāralañkā had to be reordained as required by the head of the local monastic community. ${ }^{26}$ Information about him then circulated to the capital, and he was escorted from Tavoy to Upper Burma sometime between 1766 and 1767.

During his stay in Upper Burma, Sāralañkā made a new career for himself, one that shows the value sometimes attributed to monks with exposure to the wider Southern Asian Buddhist world. On his arrival, he was accommodated in a village near Sagaing (one of the cities composing the capital area). After being 
questioned about his travels, he was transferred into the tutelage of Kyethtungin Hsayadaw (1693-1775), one of the most venerated royal teachers, also considered a model "forest-dwelling" monk. At this point, Sāralankkā's benefactor (providing for his maintenance) was the governor of Sagaing, a close ally of the late king Alaungmintaya, the founder of Konbaung dynasty (1752-1885).

Later on, Sāralañkā resided in Taungbila, a famous site near Sagaing with an excellent pedigree as a location of "forest-dwelling" monasticism. ${ }^{27}$ Finally, Sāralanikā became abbot of his own monastery located to the south of Sagaing. The construction of this monastery was started by another courtier, a relative of Alaungmintaya (who appears to occupy a higher position in the court hierarchy than the governor of Sagaing). However, this new sponsor died, and the monastery was completed by the governor of Sagaing, Sāralañkā's earlier donor. ${ }^{28}$ After staying in Sagaing for some fourteen years, Sāralan̉kā requested permission to return to his native Tenasserim. He was allowed to go, and a new testimony was recorded before his departure. The likely date when the record was made is either 1780 or $1781 .{ }^{29}$ Nothing more is known about Sāralañkā thereafter.

Sāralañkā's growing recognition during his residence in Upper Burma is reflected in the way Burmese officials who recorded his testimonies referred to him. Whereas the 1767 document identifies Sāralañkā as a "monk who has been to Sīhaḷ [sīhuil rok phunh krīh] and was brought [to Ava] by a royal inspector [nāh kham ] and clerks [cā re] of the town of Dawe," the second testimony presents Sāralañkā as a "venerable monk [phunh tau krīḥ] who had traveled from Jambudipa to the island of Sīhaḷ for the purpose of taking care of the sāsana [Buddhist teaching and tradition]" and as "the most venerable monk [phunh tau krīh phurā]." This rise from a mere "monk" to "the most venerable monk," mentioned in relation to his own achievements, was significant. Although Sāralañkā did not enjoy the most prestigious position of a royal teacher (charā tau) and did not belong to the top levels of the monastic hierarchy, he and his contribution to the Lankan sāsana were recognized by the Burmese court.

Additional documents from the same period that quote the testimonies of Sāralañkā further demonstrate his fame. The first reference appears in the Cetyavamsa (Chronicle of stūpas), a brief work in Pāli accompanied by bilingual translation composed in 1775 by Mun Ko, a writer from Bagan. ${ }^{30}$ The Cetyavamsa traces the construction of major Buddhist monuments in Burma. Mun Ko focuses on the installation of a new umbrella on Shwedagon stūpa (relic monument) by King Hsinbyushin (r. 1763-1776), then jumps back in time to list improvements made to the stūpa throughout its history, dwelling briefly on King Dhammaceti, also known as Rāmādhipati (r. 1473-1492), one of the kings who sponsored such construction. Mun Ko then provides a summary of a testimony given in 1773 by "a monk who was born in the royal city of Ayutthaya called Dvārāvatī and who came from Sīhala." ${ }^{1}$ Although the name of the monk is not mentioned and his birthplace is referred to as Ayutthaya (whereas the 1767 
testimony refers to Sāralañkā as a native of the Tenasserim area), the contents of the testimony leave no doubt that the person in question was Sāralañkā. Thus, to Mun Ko, information on Sāralanikā's travel to Lankā and details the latter provided about the sacred sites of the island were significant enough to be included alongside major milestones in the history of Buddhism and temple construction in Burma. ${ }^{32}$

Another reference to Sāralañkā's testimony appears in monastic correspondence dating to 1810 . In a reply given by monk Ariyāvaṃsa Ādiccaramsī̄ to his disciple Sirimālā and included in the anthology of such replies called Samantacakkhudīpanī (The exposition on the eye of all-around knowledge), Ariyāvamsa refers to a "record of a spoken testimony of the venerable Sāralanikāra, who has been to Sīhaḷa, [made] in the reign of Lord Hsinbyushin, the elder brother [of the present king], who had founded the third city of Yadanapura." 33 The document mentioned by Ariyāvamsa could well be a copy of Sāralañkā's 1767 testimony that survives at Ariyāvaṃsa's monastery in Monywe village. ${ }^{34}$ If indeed the record referred to by Ariyāvamsa is reflected by this manuscript, it is worth noting that it does not mention Sāralañkā by name. This fact suggests that Sāralañkā was sufficiently well known for Ariyāvamsa to attribute the testimony. ${ }^{35}$

The references in Mun Ko's chronicle and Ariyāvaṃsa's monastic correspondence (documents compiled a hundred miles to the southwest of Sagaing in Bagan and some fifty miles to the west of Sagaing in Monywe) suggest a fairly wide circulation of testimonies. Hence, in the late eighteenth century, Sāralañkā appears to have been one of the monastic celebrities of Upper Burma. At the same time, it is revealing that in both sources he is mentioned only in the context of testimonies. This suggests that Sāralaṅkā's fame derived not from his monastic practice in Burma or his personal charisma, but depended on literary works created by the Burmese interested in Lankā and on the Burmese networks of circulation through which manuscript copies of Sāralañkā's testimonies spread.

It is worth stressing that, in relation to monastic practice, the very asset Sāralan்kā transmitted to Lan̉kā — namely, his Ayutthayan ordination — was lost as soon as he had been escorted to Tavoy by Burmese officials. To continue as a monk, Sāralan̉kā was obliged to reordain into a local monastic community. Moreover, Sāralañkā's testimonies do not show much rigor in accounting for that Ayutthayan ordination or any indication that the Burmese took any interest in Sāralanikā's Ayutthayan lineage or were eager to establish a new lineage in Burma originating with Sāralañkā. Instead, he was absorbed into a Burmese monastic order and rose to relative prominence within it, capitalizing on his association with Lañkā and his ability to narrate this association in terms prized by Burmese patrons. This process of adaptation of a narrative to suit his emerging role of successful "missionary" monk is reflected in the ways the "1787" testimony differs from the one recorded in 1767. 


\section{THE DEVELOPMENT OF TESTIMONY}

The testimony of 1767 is a record of interrogation that lists the questions asked by a Burmese official and the replies provided by Sāralañkā. It gives a matterof-fact account of Sāralankā̄s travel together with a few details on the monasteries and sacred sites of Lankā. The document gives an overall impression of Sāralañkā as a person trying to downplay any individual distinction to avoid claims to authority that he might not be able to substantiate. Sāralañkā testified that his ordination occurred only few years before the arrival of the Kandyan embassy at Ayutthaya and that even on his return from Lankā he was still a "junior monk" (rahan nay). ${ }^{36} \mathrm{He}$ did not pretend to have sound scriptural training or expertise ${ }^{37} \mathrm{He}$ did not refer to being prominent anywhere he had traveled or to making a personal contribution to the Lankan mission. It is significant that he also made no effort to celebrate his belonging to a particular monastic lineage or order, providing only those details that were necessary to demonstrate that his claim on monastic status was valid in Vinaya terms so as to prove he was not a false monk.

Sāralañkā stated that the mission faced severe difficulties on the way back to Ayutthaya. Whereas the travel to Lankā occurred with combined Sinhalese, Siamese, and Dutch support, the return journey was a personal initiative, and so the monks had to find the means of survival in an alien environment. Thus, while traveling in India, they had to go from one place to another pretending to be either Malays or Javanese.$^{38}$ According to Sāralankā, the majority of monks who participated in the mission died of chickenpox during the sea journey from India to Southeast Asia. Sāralañkā also admitted that the return to Siam did not make things easier for him. He explained that, when surviving monks arrived back at Ayutthaya, the king who had sent the mission was already dead and a new king occupied the throne. ${ }^{39}$ Since the embassy's leaders had died on the mission, there was no one of influence to claim a state welcome on return to Ayutthaya. The monks only managed to transmit a message to the king. ${ }^{40}$ Sāralañkā spent one rainy season's retreat in Ayutthaya and then moved to Tenasserim. ${ }^{41}$

In contrast to the 1767 testimony, the one likely dating to 1780-1781 (but generally referred to as dated 1787) is not the product of an interrogation, but rather a lengthy narrative aimed at detailing Sāralañkā's itinerary, the situation on Lanka an, and the history of that island for the benefit of posterity. Besides offering greater detail, this later testimony also strives to explain the context that necessitated a Buddhist mission to Lañkā. This new conceptual framework was accompanied by a revised chronology of events, a different itinerary (especially of the return journey), and inflated claims about the prominence of the mission. In a later section, I will address the wider Burmese context for the new conceptual framework into which Sāralañkā’s activities were drawn. 
In 1767, Sāralaṅkā failed to report certain details, citing poor memory. By the 1780s, his memory was refreshed to the extent that he could provide an account that looked essentially complete. If in 1767 he managed to name only thirteen out of thirty monks whom he claimed to have participated in the mission, in the second testimony he provided a full list of thirty-two names (the alleged number of missionaries increased by two) together with their native places. Departing from his earlier statements that he went to Lankāa as a junior monk with only a few years of monastic standing, following his preceptor, Sāralanikā now claimed that, after the arrival of Sinhalese envoys to Ayutthaya, the king assembled all monks residing in the area, offered alms food, and requested to select four mahätheras who had completed twenty rainy seasons and were forty years old and twenty-eight monks who were thirty years old and had ten years of monastic standing. Thus, instead of being a poorly educated bhikkhu accompanying his teacher two years after ordination, Sāralañkā became one of the monks who was ordained for ten years and chosen by the entire Ayutthayan saingha to travel to Lañkā. ${ }^{42}$

Sāralañkā also claimed that, on selection, monks chosen to transmit the ordination to Lan̉kā were given special scriptural training lasting for a year and that this scriptural expertise was imparted to newly ordained Sinhalese monks. ${ }^{43}$ Almost every detail related to the mission's experience during the journey that did not sit well with the grand purpose of the mission was corrected from the earlier testimony in a way that strengthened the mission's profile. Thus, mention of disguising as Malays, deaths from chickenpox, and lack of interest shown to the survivors on their arrival back in Ayutthaya had all disappeared. Instead, Sāralañkā spoke about reverential treatment the VOC extended to the mission during the latter's residence at Batavia on the way to Laṅkā, added new details about the arrangements the Kandyan king Kīrti Śrī made to greet the mission on its approach to Kandy, and recounted the ceremonial welcome the mission received on return to Ayutthaya as well as lavish donations bestowed on its members who chose to travel back to their native cities (like Sāralañkā, who returned to Tenasserim). ${ }^{44}$

Sāralankā's facility in manipulating the data for the second testimony is further highlighted by the fictional genealogy he provided for King Kīrti Śrī and the claim that the latter was ordained and lived for one year as a monk following the arrival of the mission in Lankā, a story that finds no support in other sources. Another significant instance of retouching was the conflation of two missions from Ayutthaya in 1753 and 1756 into one: the second testimony identified the leaders of both the first and the second missions from Ayutthaya to Kandy as participants of a single mission. This eliminated the possibility that the role of the 1756 mission (in which Sāralañkā appears to have participated based on the first testimony) would be interpreted as purely supportive rather than as foundational to the Ayutthayan-Kandyan interaction. 
Despite the embellishments and reformulations evident in the second testimony, it is important to note that Sāralañkā's testimonies were not completely fictional. They demonstrated a sound knowledge of Lankan geography and sacred sites, navigation routes in the Indian Ocean, and names of Sinhalese officials, and he correctly identified the names of Siamese ministers who were sent to Lankā in 1756 as well as the names of monks who headed the missions to the island. These points suggest that discrepancies in the testimonies and fictionalization of the narrative were mostly strategic and served to create an account that would ultimately be intelligible to and perceived as trustworthy by a Burmese audience. Apparently, a testimony that looked complete and described a successful mission that was well received throughout its journey suited the expectations of that audience better than a more straightforward report that included more signs of risk, contingency, and failure. The circulation and survival of copies of the testimonies prove that Sāralanikā managed to pass the tests of intelligibility and trustworthiness within the Upper Burmese Buddhist monastic context. Both the adjustment of Sāralañkā's testimonies and the importance accorded to them in Burmese manuscript circulation shed light on one of the forms of circulation identified in the first section of this chapter. Sāralañkā's experience in Upper Burma is a striking example of the transmission and localization of things and persons within the Southern Asian Buddhist world in contexts that did not involve the transplantation of either monastic lineage or a monastic order but did involve an adaptation to local circumstances. Thus, the processes of localization involving mobile monastics can be examined both at the scale of monastic ordination lineages and the Buddhist orders that they shape (as noted by Blackburn) as well as at the scale of individuals. ${ }^{45}$

\section{LOCALIZATION AND INTELLIGIBILITY}

At first glance, the career of Sāralañkā may seem disjointed — consisting of discrete parts with little logic connecting them - and contradictory, to the extent that no truthful testimony of it could be made. A boy from a village near a remote Siamese port city travels to the royal capital and is ordained there. Soon, while still a junior monk with few qualifications, he becomes a part of an important monastic mission, important at least in retrospect (there are no means of ascertaining how the mission was perceived by those who initiated it). Spending some years in a distant country and surviving the hardships of a perilous journey, Sāralanikā returns to Ayutthaya and might be expected to enjoy the accruing glory. Yet Ayutthaya is in decline, and so he chooses to return to his native area. Tenasserim, however, is not a safe haven either, and soon Sāralañkā is displaced by the Burmese but manages to reassert himself as a venerable monk in Upper Burma. These ruptures and twists in his career leave one to wonder if Sāralañkā was ever in control of his itinerary and career trajectories. To what 
extent, if at all, did his earlier background and relationships shape his subsequent evolution?

Sāralañkā's career as evidenced by his testimonies departs significantly from normative accounts of Lankan or Southeast Asian monasticism as found in such sources as the Mahāvamsa, an early sixth-century Lankan chronicle, or official Burmese chronicles. It would be unimaginable in modern Sinhalese or Thai narratives of the establishment of Siyam Nikāya or Nikāya Siyamwong (Siamese Lineage), which tend toward a panegyric account of monastic missions. Sāralañkā seems an unlikely candidate for the transmission of ordination and a successful monastic career, for he does not possess an exalted lineage, sound education, scriptural expertise, or notable charisma. His corporate status as a fully ordained monk and a cofounder of the Siyam Nikāya in Kandy neither helped him to find a suitable place on return to Ayutthaya nor protected him from deportation to Upper Burma.

In fact, by the nature of his origins and interstitiality, Sāralañkā was an ideal candidate for perilous travels, someone who could have been considered expendable by authorities yet also capable of surviving in challenging new settings. Though necessitating reordination at Tavoy in 1765 or 1766, Sāralañkā's status as a captive and one of non-Burman background did not preclude his being venerated by the Burmese court and receiving his own monastery in Sagaing. In fact, it was Burma, not Lan̉kā or Siam, where Sāralañkā achieved greatest personal prominence. Marginality and personal insecurity enhanced Sāralañkā's ability to adopt whatever socially approved behavior (including the notions of monasticism) was expected from him. This ability is clear in the way he reshaped his second available testimony vis-à-vis the earlier one to suit his acquired status as an eminent monk and recipient of high-level patronage. And it is likely this ability to adapt that brought Sāralanikā closer to prestigious social roles and modes of action. The adaptation displayed by Sāralañkā in his testimonies shows how authoritative discourses on Buddhism and monastic activity are shaped by negotiation between those speaking and writing and their audience. In turn, this type of negotiation raises the issue of the role of local audience reception in the context of Buddhist mobility, allowing us to expand our analytical understanding of the processes through which Buddhist travelers were localized in particular settings and drawing attention to the ways in which the receiving culture's or community's goals and needs could take precedence over formal measures of knowledge and experience of mobile Buddhists. Indeed, local Buddhist communities had an impressive ability to capitalize on long-distance contacts within Buddhist oikumene and to situate itinerant monks and the connections they might symbolize into local projects and conceptual frameworks.

When examined in relation to other contemporary Burmese documents detailing long-distance religious travel to and from Upper Burma in the late 
eighteenth century, Sāralañkā's case appears representative of a fairly large group of "foreign" religious specialists who provided the Burmese court with information on neighboring countries and facilitated Burma's interactions with them. Such evidence reveals a pattern to these interactions, with the Burmese already having a certain idea about a particular foreign destination and its value, construing the "foreign" actor as able to serve their aims. Accordingly, as in Sāralañkā's case, the Burmese absorbed the details provided by a "foreigner," while conveying to the traveler their own understanding of the matter at hand and catalyzing the traveler's adaptation to local circumstances. The fusion of "local" and "foreign" elements in Sāralañkā's testimonies is illustrated below.

The development of Sāralañkā's testimonies was not limited to enhancing his image. Equally notable is his tendency to refer to locally significant sacred sites and religious practices as well as to adapt Burmese historiographical notions. For instance, one of the features of the testimonies is the mapping of Lank $\bar{a}$ according to an understanding of the Burmese religious landscape, where major Buddhist sites of Lañkā are compared to stūpas in Burma. ${ }^{46} \mathrm{We}$ see another example in Sāralan̉kā's use of Burmese monastic curricular terms to frame a description of how Siamese monks from Ayutthaya trained Lankan monastics. According to the testimony, fifty newly ordained Lankan monks who had the ability to preach were assigned to act as preceptors in "all curricular

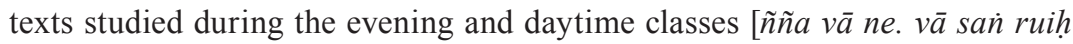
kyamh akun]." ${ }^{\prime \prime 7}$ This description imposed the structure of monastic education in Upper Burma on the training allegedly given to Sinhalese monks by their fellows from Ayutthaya. The division into daytime ( $\tilde{n} \tilde{n} a v \bar{a})$ and evening (ne. $v \bar{a}$ ) classes - the former dedicated to Pāli grammar and Vinaya, and the latter to Abhidhamma-reflected the basic daily routine in Burmese monasteries. The term "curriculum" (san ruih) also closely resonated with Burmese notions of monastic training, since by the late eighteenth century a significant share of monasteries in Upper Burma based the education of schoolboys, novices, and junior monks on a similar selection of Pāli and bilingual texts. ${ }^{48}$

Finally, Sāralañkā's account of the history of Sinhalese kingship and the situation of the sāsana on the island (provided in his second available testimony) displayed an interesting fusion of local, unofficial Burmese historiography with more standard Lankan narratives. Though the sequence of rulers of Lankā from Vijaya to Kīrti Śrī given by Sāralañkā depended on the Mahāvaṃsa to a certain degree, it omitted the majority of kings mentioned in the Lankan chronicle. It did, however, refer to Dharmapāla - a puppet king installed by the Portuguese at Kottẹe in the sixteenth century who was also in contact with the Burmese king Hsinbyumyashin (r. 1551-1581) who ruled at Hanthawady (Bago). Since at least the early seventeenth century, Burmese sources identified Dharmapāla as a rightful sovereign of Lañkā who fought "Indian" non-Buddhists (micchäditthi) ruling at Kotțēe [sic], Kandy, and Sītāvaka and finally managed to subdue them and unify the island with the help of Hsinbyumyashin. ${ }^{49}$ Strikingly, Sāralañkā 
retells this story-apparently unknown in Kandy or Ayutthaya-in a form diverging from mainstream Burmese court historiography but consonant with local traditions at Sagaing, where he resided in Burma. ${ }^{50}$ All the monasteries where Sāralankā resided between 1767 and about 1781 were located in direct proximity to a site that embodied the tradition about Hsinbyumyashin and the king of Lankā. Therefore, departures from official Burmese narratives in Sāralan̉kā's testimony indicate that Sāralan̉kā's retelling was based not on Burmese texts, but rather borrowed from some local oral version that Sāralañkā likely heard in Sagaing.

\section{SĀRALAN̉KĀ, THE BURMESE ROYAL COURT, AND A WIDER BUDDHIST WORLD}

Strategic use of idioms comprehensible to the Burmese public undoubtedly contributed to Sāralañkā's local intelligibility. Of even greater importance, however, was the fact that Sāralañkā's travels were compatible with Burmese notions of Burma's position within a wider Buddhist world. Moreover, Sāralañkā's residence in Sagaing coincided with late eighteenth- and early nineteenth-century Burmese royal interest in refining its knowledge of the broader Buddhist world and expanding engagement with it. The success with which Sāralañkā localized himself in Upper Burma - although he was not sought after as the officiator to found a new monastic lineage or as a participant in a valued foreign monastic order-reflects the importance of this specific historical moment when mobile monastic elites were particularly valued at the Burmese court.

Scholarship on the reign of King Badon-min (r. 1782-1819) has long referred to multiple Burmese missions sent to India during this period. Modern Burmese works mention in particular 170 Sanskrit texts that were brought from Nabadwip (an important center of Sanskrit learning and a Vaishnava pilgrimage site in West Bengal) and transcribed from Bengali into Burmese Sanskrit. They were then recopied on palm leaves under the supervision of Nānāabhivamsa (1751-1832), a key court-sponsored monk and the future head of the royal monastic hierarchy, in $1786 .^{51}$ Manuscript evidence provides further context for such embassies to the Indian subcontinent. In 1783, the minister for palatial affairs (atvan van) Min Letwe Nawyahta U Ne (1723-1791) wrote to Ñānābhivamsa requesting a list of "works of worldly knowledge" (lokī kyamh; a common phrase used to refer to Sanskrit and Sanskrit-derived texts) that were unavailable in Burma and should be sought in the "foreign country of sea-vessel-[faring] Indians." This request arose in the context of Badon-min's sponsorship of copies of Pāli Buddhist texts and learned Sanskrit works, leading to the recognition of the inadequate availability of Sanskrit texts in Burma. Nāṇābhivamsa identified forty-eight titles that had been available in Burma in the past but were now lost. A year later, Punshi and Sukāram (two royal Brahmins, of either Bengali or Tamil descent, ${ }^{52}$ serving at the Burmese court) 
were sent to Kolkata accompanied by Yangon-based merchant captain Thiri Sandarat ${ }^{53}$ From Kolkata they were referred to Nabadwip, where they managed to recopy a number of texts, most of which were actually not suggested by Ñānābhivaṃsa. A year later, they arrived at Amarapura, inaugurating a transcription project completed by late $1786 .{ }^{54}$

This acquisition of Sanskrit intellectual heritage highlights Burmese participation in wider South Asian religious and intellectual networks as well as the need for information and intermediaries that supported such Burmese goals. In the view of the Burmese elites, the royal corpus of Sanskrit works was authoritative not because of its Indian origins, but as a result of its use in Upper Burma. Min Letwe Nawyahta made no indication of Badon-min's interest in expanding the royally transmitted corpus of Sanskrit texts, and Ñānāahbivamisa was asked to identify only those titles that were recopied in Burma in the past. ${ }^{55}$

Also helpful in contextualizing Sāralankā's reception in eighteenth-century Burma is the evidence on Burmese communications with Lankā and Qing China in the late eighteenth century. What seems to be the earliest direct contact between the court of Badon-min and the Sinhalese resulted from sending Thiri Sandarat, the captain who had traveled to Kolkata, Nabadwip, and Lañkā. In about 1787, he was instructed to check whether Lankā still possessed the Buddha's tooth relic, the forehead bone relic, the relic of the hair between the eyebrows, and the Bodhi tree brought from India, as described in the Buddhist historiographical works Mahāvamsa, Dīpavamsa, Bodhivamsa, and Nalätadhätuvamsa. He was also instructed to see whether the conduct of Sinhalese monks and novices was in conformity with the Vinaya. ${ }^{56}$ In late 1789, Thiri Sandarat returned to Amarapura accompanied by Sinhalese novice Varakālantē and a senior mason Narāyanapā, bringing a manuscript of Dhammacakkapavattana Sutta and its bilingual commentaries as well as messages from an unidentified Sinhalese "king" and high-ranking monastic leader (anunāyaka) of Anurādhapura. ${ }^{57}$ The message of the anunāyaka recounted the ecclesiastical history of Lankā, mentioning its prior contacts with other parts of Southern Asia for the purposes of monastic ordination and eulogizing Kandyan monarchs for taking perfect care of the country and the sāsana ${ }^{58} \mathrm{~A}$ message that the Burmese identified as being sent by the Sinhalese king requested a number of Pāli texts..$^{59}$

Badon-min and Ñānābhivamsa made a selective reading of the messages focusing on three points: that Lankā had a recent history of importing monastic ordination from elsewhere in the region, that there was no complete tipitaka available in Lañkā, and that the Mahācetiya (Great Relic Monument) in Anurādhapura had no umbrella installed on top. This, in current Burmese understanding, signified a dramatic neglect of the sacred site. Ñānāahbivaṃsa laid plans to give Varakālantē proper scriptural training, ordain him as a monk, learn Sinhala script from him, prepare a full set of tipitaka transcribed in Sinhala, and send a mission under Nāṇābhivamisa himself to reestablish the 
sāsana on Lañkā. In the meantime, Narāyanapā would return to Lañkā and confirm the favorable reports made by Thiri Sandarat about the flourishing state of the teaching in Burma, and a son of Thiri Sandarat should be sent with the funds to repair major monuments. Such measures were intended to convince Lankan Buddhists that the well-being of the sâsana could be entrusted to the care of Badon-min. ${ }^{60}$

This example illustrates the performative or "symptomatic" role the engagement with overseas Buddhist locations played in Southern Asian Buddhist cultures of the period. That is, engagement with valued persons and objects from the wider transregional Buddhist world stemmed from specific local historical circumstances and, as such, highlights key moments of institutional instability and/or ambition within local contexts. ${ }^{61}$ Within the Buddhist world of that time and indeed earlier, lay Buddhist patrons and monastic leaders were defined as leaders in part through their ability to contribute to the cause of the sassana on a global level. They portrayed themselves and were seen as participants in a greater Buddhist oikumene instantiated by relics, sacred sites, manuscripts, and ordination opportunities, supported by Pāli and Sanskrit literature and their vernacular adaptations, Buddhist art, and, sometimes, accounts of foreign informants such as Sāralañkā. ${ }^{62}$ Of course, Ñānābhivaṃsa may have overstated his aims in offering to reordain the monks on Lankā; thinking small was not an option for a person responsible for taking care of the sāsana on behalf of a Burmese king, especially one as ambitious as Badon-min. ${ }^{63}$

The interactions of the Konbaung court with China displayed similar willingness of the Burmese to offer their ordination and mastery of Pāli texts to a wider Buddhist world and to patronize "foreign" relics. Communications with the Qing started roughly at the same time as the travels of Thiri Sandarat. By 1787, local rulers (Ch. $t u ̌ s \bar{l})$ from the Burma-Yunnan border facilitated the delivery of a letter from the Qianlong emperor (r. 1736-1796) to Badon-min. A few years later, they set up the delivery of three princesses identified as Chinese, given as brides to Badon-min, an act potentially signifying in local eyes that the Qianlong emperor might be recognized as a Burmese vassal. ${ }^{64}$

From the beginning of these exchanges, the Burmese court chose to frame them in relation to the well-being of the sāsana. Among diplomatic gifts exchanged between the two courts, a prime place was given to religious symbols. At the suggestion of Nānāabhivamsa, an exhortation to Qianlong to worship the Three Jewels (the Buddha, dhamma [teaching], and saingha) was added to the reply to the 1787 letter mentioned above. ${ }^{65}$ Moreover, the Burmese embassy sent to China in 1788 to deliver a reply apparently displayed keen interest in the Buddha's tooth relic that the Burmese believed to be kept at Mt. Wutai. As a result, the embassy returned to Burma bringing the image of the Buddha said to be worshiped by Qianlong and made in the likeness of the Buddha that the Mt. Wutai tooth relic had assumed during a visit of the Kangxi emperor (r. 1661-1722) to the site. ${ }^{66}$ Another valuable object brought by the embassy was 
the replica of the tooth relic. In a message to Badon-min, Nāṇābhivaṃsa confirmed that he was aware of the story of Kangxi's arrival at Mt. Wutai and that the image constituted a genuine relic. ${ }^{67}$ At his suggestion, the image and a copy of the tooth relic were enshrined in Pahtodawgyi in Mingun, a stūpa meant to be Badon-min's chief work of merit.

Ñānābhivamsa's 1796 correspondence with the monks of Köng-ma (Ch. Gěngmă; Bur. Kaingma), a Tai principality on the Burma-Yunnan frontier (in what is now Líncāng Prefecture of Yunnan), also shows Ñānābhivaṃsa's vision for the Tai areas. Addressing the monks from the location that played a critical role in the communication between the Qing and Konbaung courts, Ñāṇābhivamsa cited Badon-min's good deeds, mentioning, for instance, his Buddhist diplomacy with Kandyan king Rājadhi Rājasiṃha (r. 1782-1798). The message also suggested that Köng-ma monks should emulate the example of monk Ekāmuni from Möng Hsa (Bur. Maingtha, an A-ch'ang town in what is now Déhóng Prefecture of Yunnan), who came to Amarapura in Upper Burma to be reordained and trained in the curriculum promoted by Nāṇābhivaṃsa and his monastic allies. ${ }^{68}$ This recommendation underscores the desire of Upper Burmese court elites to establish stronger symbolic links with those who mediated their interactions with the Chinese administration in Yunnan and the Qing imperial court, while promoting conformity with Burmese notions of the sāsana among the Tai.

This evidence of concerted, heavily resourced overtures from the court of Badon-min to key nodal points in the Buddhist ritual and wider geopolitical worlds of Southern Asia (and beyond) helps to clarify the position of Sāralañkā in Upper Burma and his ascendance to a high rank within royally sponsored monastic circles. Burmese royal conceptions of a greater Buddhist world created a demand for agents able to affirm and animate these geographies and to provide vital practical information that facilitated strategic royal engagement with subregional locations beyond Burma. Although this chapter has concentrated on the ways in which Sāralanikā adapted his reports of the Buddhist world to suit his Burmese audiences, it is also evident from Sāralañkā's testimonies (and the way they were quoted in subsequent Burmese texts) that his reports were understood as valuable sources of current information on the condition of particular Buddhist sites and travel routes.

Since the Konbaung court's influence beyond the borders of the Burmese polity was limited, religious initiatives of the Burmese crown on its peripheries outside of Burma proper depended on intermediaries and collaborators in a way similar to the functioning of hybrid or plural political structures on the Burma-Yunnan frontier. Though Sāralanikā was not strictly an agent of the Burmese court, the interest in his testimonies and the way they were quoted by contemporaries suggest that he was seen as a source of valuable information about Buddhist institutional locations with which Burmese royal and monastic leaders were concerned. 
Facilitation of Burma's religious and diplomatic contacts in the eighteenth and nineteenth centuries involved a broad and nonsectarian mix of actors, operating on sea and land routes across Asia and the Indian Ocean. In addition to Buddhist monks of diverse ethnic origin, these interactions relied on European trade companies and colonial powers as well as on Asian trading, religious, and administrative networks (such as Tamil merchants, port masters, and laborers from Lankāa and the Coromandel coast; Arakanese and Armenian traders, officials, and entrepreneurs from the Burma-Yunnan frontier; Bengali Brahmins; and even Sufi Muslims). ${ }^{69}$ Foreign religious practitioners who found their way to Upper Burma and passed local tests of intelligibility were received as significant social actors. Brahmins, Sufis, and Buddhist monks and novices were associated not with margins, but with political and religious centers outside Burma with which they were familiar and about which they could provide information. Some of them came to be rewarded or patronized by the Burmese royal court, which valued such skills as a command of Persian as a language of diplomacy or proficiency in astrology, alchemy, or medicine.

Research in history and the social sciences during the last twenty years has seen the burgeoning of work on border areas and social agents operating in interstitial spaces between lowland states and polities as well as studies of groups and networks acting on the margins or peripheries of large territorially organized social bodies. In Asian studies, this work has led to the development of such concepts as "the history at the interstices" or Zomia that, among other things, called for rescaling conceptual tools to recognize the subjectivity of regions and people that had not been adequately represented in previous research. ${ }^{70}$ In China studies, an important trend has been research on hybrid regimes and "dual sovereignty" that Ming and Qing imperial states employed at their frontiers. This research has focused attention on multiple native collaborators on imperial frontiers as well as other indigenous actors. ${ }^{71}$ In research on global trade and colonial expansion in the Indian Ocean, growing attention has been paid to social formations of mobile individuals able to function as entrepreneurial minorities. Gujarati baniyas, Julfan Armenians, Peranakan Chinese, Parsis, and participants in many other networks termed "conjoint communities," "communally defined trading groups," and "circulation societies" were the primary Asian actors exploiting the opportunities for long-distance trade, financial, and industrial operations created by indigenous and colonial empires. ${ }^{72}$ In the case of Southeast Asia, such research has been complemented by work on Chinese and Arab networks in the region. ${ }^{73}$

In the study of Southeast Asian religions, however, a comparable depth of detail on interstitial actors is yet to materialize, although a substantial literature has emerged on the role of Indian intermediaries in the circulation of Islam in Southern Asia. ${ }^{74}$ In the field identified as Theravāda studies, the study of Buddhism oriented toward authoritative texts in Pāli, the mapping of peripheral 
figures has just begun. The most significant example is the recent work on the activities of pioneer Western Buddhists in Asia, ${ }^{75}$ but there are no corresponding studies of indigenous itinerants or of mobile Buddhists before the colonial period. ${ }^{76}$ The present chapter on Sāralanikā draws attention to this category of actors and shows the ability of a particular monastic itinerant to rise in the Burmese monastic order by virtue of his reception as someone able to contribute to Burmese support for the cause of the sāsana within a greater Buddhist world.

Sāralanikā's case and other examples referred to more glancingly in this chapter illustrate that mobile Buddhists in eighteenth-century Southern Asia made their careers either by fusing into monastic orders at their destinations or by facilitating the development of these monastic orders, often by providing a monastic ordination. These cases do not reveal the extension of Buddhist monastic orders - with their external features of organizational structure and practice - into new foreign locations. ${ }^{77}$ Mobility associated with the import of an ordination, as in the establishment of Siyam Nikāya or movements of Burmeseordained monks in Tai areas on the Burma-Yunnan frontier, was made possible by awareness of a greater Buddhist world transcending political boundaries, by the hybrid nature of communication networks through which diplomatic activities of regional polities were carried out, and by diverse benefits Southern Asian Buddhists and their patrons could derive from venturing into foreign territories.

Thus, this case invites us to consider when and to what extent ordination lineages play a formative role in the institutionalization of Buddhist monastic communities. In my work on eighteenth- and nineteenth-century Burmese monastic organization, I find lineages largely irrelevant or at least much less relevant than ritual communities, reformist networks built around signature practices, royally supported hierarchies, and educational infrastructure. ${ }^{78}$ At the same time, in her analysis of the rise of Siyam Nikāya on Lankā and the development of Sīhaḷ Sañgha in Northern Thailand, Blackburn argues that the invocation of imported lineages provided an avenue for reconfiguring local communities and enhancing their claims for recognition. ${ }^{79}$ To me, the perspective on the foundation of Siyam Nikāya offered in Sāralañkā-related materials suggests that the ordination brought from Ayutthaya merely fulfilled ritual requirements for inaugurating a new monastic lineage in Kandy and reviving Sinhalese monastic order. Neither the lineage, nor the order in this case could be called "imported" in the strict sense of the term.

The compartmentalization of the Buddhist world into multiple polities created opportunities for itinerant religious specialists, who may have been drawn to mobility by social marginality in their places of origin or other instabilities such as wartime conditions. Navigating these spatial formations required many skills, including those demonstrated by Sāralañkā, who was able to mix creatively idioms that were vernacular and local with those that were cosmopolitan and transregional. Barriers to and opportunities for the localization of itinerant religious specialists varied greatly from one location in Buddhist Southern Asia 
to another. For example, the Upper Burmese situation appears different from Lank $\bar{a}$ in the eighteenth and nineteenth centuries, where the close dependence of the formation of monastic orders on the social organization of Sinhalese society (especially in terms of caste hierarchies) and the exclusivist and centralized nature of the dominant monastic community (Siyam Nikāya), with its strict control over access to monastic ordination and bureaucratic appointments, likely limited the prospects for such actors as Sāralañkā. ${ }^{80}$ More research is required to develop detailed comparisons and identify structural possibilities for the localization of foreign persons, ideas, and practices into Burmese, Sinhalese, Tai, or Thai monasticism and for long-distance networking within the Southern Asian Buddhist world over time. Localization strategies such as that employed by Sāralañkā were used elsewhere in Buddhist interactions in early modern Southern Asia during the eighteenth as well as parts of seventeenth and nineteenth centuries. More research is required, however, to determine how common such strategies were in earlier periods and which social and political features may have shaped the success or failure of itinerants seeking a favorable reception in the Southern Asian Buddhist world. It is equally interesting to see how the processes and strategies involved in receiving and localizing mobile Buddhists might have been transformed when interactions between Buddhist countries intensified during the late nineteenth century, producing a more complex intellectual climate and a broader mix of localization patterns characteristic of the modern period.

\section{NOTES}

I am grateful to Anne Blackburn and Michael Feener for numerous discussions relevant to the subject of the present chapter as well as for comments and editorial suggestions on its drafts; to Arina Mikhalevskaya for discussions of sources on Qing-Konbaung interactions; to Ko Than Zaw and Ko Soe Nyunt, whose assistance was indispensable during fieldwork in Monywe village, Burma; to Hsayadaw U Jānadhamma, abbot of the Monywe Zetawun monastery, for allowing me to study the manuscripts in his custody; and to the Myanmar Department of Archaeology and National Museum, Ministry of Culture, as well as to Daw Baby, director, Archaeological Museum of Bagan, for providing access to manuscripts in the museum collections.

1. Kenneth Roy Norman, Pāli Literature Including the Canonical Literature in Prakrit and Sanskrit of All the Hīnayāna Schools of Buddhism, A History of Indian Literature, vol. 7, fasc. 2 (Wiesbaden: Otto Harrassowitz, 1983), p. 13.

2. Mon Bokay, "Relations between Ceylon and Burma in the 11th Century AD," in Essays Offered to G. H. Luce, edited by U Ba Shin, Jean Boisselier, and A. B. Griswold, vol. 1 (New York and Ascona: Artibus Asiae, 1968), p. 94; Kanai Lal Hazra, History of Theravāda Buddhism in South-East Asia: With Special Reference to India and Ceylon (New Delhi: Munshiram Manoharlal, 1982), pp. 89, 92, 103, 111, 130; Tilman Frasch, "A Buddhist Network in the Bay of Bengal: Relations between Bodhgaya, Burma and Sri Lanka, c. 300-1300," in 
From the Mediterranean to the China Sea, edited by Claude Guillot, Denys Lombard, and Roderich Ptak, South China and Maritime Asia 7 (Wiesbaden: Harrassowitz, 1998), pp. 83, $85,89$.

3. Niharranjan Ray, An Introduction to the Study of Theravāda Buddhism in Burma (Calcutta: University of Calcutta, 1946), pp. 114-115, 171, 190-192; C. E. Godakumbura, "Relations between Burma and Ceylon," Journal of the Burma Research Society 49.2 (1966): 147; Hazra, History of Theravāda Buddhism, pp. 103, 108, 111; Emmanuel Guillon, "Jalons pour une histoire du Bouddhisme en Asie du Sud-Est," Péninsule 8-9 (1984): 124. Others argued that the expansion of Sinhalese monasticism in Southeast Asia manifested competing forms of Sinhalese monastic tradition, especially with respect to ritual practice. See, for instance, Prathip Chumphon, "Khor sanitsathan ruang phra malai," Wannakhadi wikhro 1975; François Bizot, Les traditions de la pabbajjā en Asie du Sud-Est (Göttingen: Vandenhoeck and Ruprecht, 1988). For an alternative view, see Prapod Assavavirulhakarn, The Ascendancy of Theravāda Buddhism in Southeast Asia (Chiang Mai: Silkworm, 2010), pp. 170-172.

4. Peter Skilling, "Theravāda in History," Pacific World: Journal of the Institute of Buddhist Studies, third series, 11 (2009): 63-64; Anne M. Blackburn, "Sīhạ̣a Sangha and Lañkā in Later Premodern Southeast Asia," in Buddhist Dynamics in Premodern Southeast Asia, edited by D. Christian Lammerts (Singapore: Institute for Southeast Asian Studies, 2015), pp. 315-322; Anne M. Blackburn, "Buddhist Connections in the Indian Ocean: Changes in Monastic Mobility, 1000-1500," Journal of the Economic and Social History of the Orient 58 (2015): 251-257. See also Jason A. Carbine, "How King Rāmādhipati Handled His Boundary Case: Sīmā, Sāsana, and Buddhist Law," Buddhism, Law, and Society 1 (20162015): 151-152, which follows Blackburn in her arguments regarding the significance of Lan̉kā.

5. For the context of this monastic reform, see Kitsiri Malalgoda, Buddhism in Sinhalese Society 1750-1900: A Study of Religious Revival and Change (Berkeley: University of California Press, 1976), pp. 54-58; Anne M. Blackburn, Buddhist Learning and Textual Practice in Eighteenth-Century Lankan Monastic Culture (Princeton: Princeton University Press, 2001), pp. 37-38.

6. For an analysis of how Saranamkara drew on Sinhalese literary and cultural heritage in developing the innovative techniques he used to reshape monastic education and preaching, fashioning the emergence of the Siyam Nikāya as a new Buddhist textual community, see Blackburn, Buddhist Learning.

7. P. E. Pieris, "An Account of King Kirti Sri's Embassy to Siam in 1672 Saka (1750 A.D.)," Journal of the Royal Asiatic Society, Ceylon Branch 18 (1903): 17-44; P. E. E. Fernando, "An Account of the Kandyan Mission to Siam in 1750 A.D.," The Ceylon Journal of Historical and Social Studies 2.1 (1959): 37-83. Both articles are translations of reports on a mission that sailed to Siam in 1750 and returned to Lankā in 1753, compiled by two officials who took part in the mission. The first is a translation of the account written by Ällepola Mohoțtāla, and the second is a translation of the work of Vilbāgedara Muhandiram.

8. Anne M. Blackburn, "Lineage, Inheritance, and Belonging: Expressions of Monastic Affiliation from Lañkā," in How Theravāda Is Theravāda? Exploring Buddhist Identities, edited by Peter Skilling, Jason Carbine, Claudio Cicuzza, and Santi Pakdeekham (Chiang Mai: Silkworm, 2012), pp. 279-281. Blackburn further suggests that such treatment might be due to the nature of the source and its primary focus on the meritorious deeds of kings, Kīrti Śrī in this case. It might be assumed that Thai sources, linked to the missions' origin, would be better 
equipped to shed light on these activities, but so far only a few original documents have been brought to light. See Supaphan na Bangchang, "A Pāli Letter Sent by the Aggamahāsenāpati of Siam to the Royal Court at Kandy in 1756," Journal of the Pali Text Society 12 (1988): 185212; Damrong Rajanubhab, Ruang praditsathan phrasong sayamwong nai Langkathaweep (Bangkok: Matichon, 2003).

9. Blackburn, "Sīhaḷa Sañgha," pp. 214, 220-221.

10. Studies of the formation of Amarapura Nikāya are also silent about the practices that might have been introduced to Lanka as a result of imported ordination. Malalgoda, Buddhism in Sinhalese Society, pp. 94-100; Masahiro Kitsudo, "A Survey of the Founders of the Amarapura Nikāya in Burma (Myanmar): Their Journeys and Higher Ordinations," Journal of Sugiyama Jogakuen University: Humanities, Social Sciences, Natural Sciences 33 (2002): 153-172.

11. Malalgoda, Buddhism in Sinhalese Society, pp. 132-172; Anne M. Blackburn, Locations of Buddhism: Colonialism and Modernity in Sri Lanka (Chicago: University of Chicago Press, 2010).

12. Anne M. Blackburn, "Localizing Lineage: Importing Higher Ordination in Theravādin South and Southeast Asia," in Constituting Communities: Theravāda Buddhism and the Religious Cultures of South and Southeast Asia, edited by John Clifford Holt, Jacob N. Kinnard, and Jonathan S. Walters (New York: State University of New York Press, 2003), pp. 133-140. The quote is from p. 139.

13. Blackburn, Buddhist Learning, pp. 136-137.

14. Ibid., pp. 58-59. More recently, Kate Crosby, Andrew Skilton, and Amal Gunasena have argued that texts transmitted to the Kandyan court included works on "traditional" Southeast Asian kammatthāna meditation and that this meditation practice was imparted to Sinhalese monks. Unfortunately, no evidence on the use of this practice and its likely scale of penetration is provided. Kate Crosby, Andrew Skilton, and Amal Gunasena, "The Sutta on Understanding Death in the Transmission of Boran Meditation from Thailand to the Kandyan Court," Journal of Indian Philosophy 40.2 (2012): 177-198. Lorna Dewaraja mentions that the persuasion of Siamese monks was instrumental in the transformation of Asela Mahā Perahera, a principal Kandyan festival that became focused on the Buddha's tooth relic instead of Hindu deities, yet the evidence for this remains unclear. Lorna Dewaraja, "Thailand's Gift to Sri Lanka: the Establishment of the Siam Nikaya," The Daily News (Sri Lanka), May 14, 2003, http://www.budsas.org/ebud/ebdha241.htm, accessed January 10, 2013.

15. Undated palm-leaf manuscript from the Zetawun monastery, Monywe village, Monywa township, folio $k a^{\mathrm{v}}$.

16. Palm-leaf manuscript no. 10551 in the Universities' Central Library (UCL), Yangon, folio $\underset{\text { dam }}{\mathrm{v}}$.

17. Library records show that the manuscript was acquired from Daw Ma Ma Gyi Bell from Yangon, but that person was merely a dealer. No details on its earlier provenance are known.

18. Testimonies provide conflicting dates for Sāralañkā's birth (1732 in the 1767 testimony and 1730 in the "1787" testimony; neither date can be reconciled with other data in the documents) as well as his monastic ordination (1754 in the former and 1753 in the latter testimony; both seem questionable). His arrival in Lanka is dated to 1757 in the former and to either 1758 or 1756 in the latter testimony (it is ambiguous on that point), with only 1756 historically probable. 
His departure from Lanka is likewise uncertain, dated to 1763 in the former testimony and to 1762 in the latter. Sāralankeā's return to Ayutthaya is dated to late 1764 in the 1767 testimony and to early 1764 in the latter.

19. Ms. from the Zetawun monastery, f. $k a^{v}$.

20. See Michael Smithies, "Seventeenth Century Siam: Its Extent and Urban Centres According to Dutch and French Observers," Journal of Siam Society 83.1-2 (1995): 62-78.

21. Ms. from the Zetawun monastery, f. $k a^{\mathrm{v}}$.

22. Ibid.; ms. no. 10551 in UCL, f. dam $\underline{n}^{\mathrm{v}}$.

23. Ms. from the Zetawun monastery, f. $k a^{v}$; ms. no. 10551 in UCL, f. $\operatorname{dam}^{v}$.

24. Ms. no. 10551 in UCL, ff. $d a m^{\mathrm{v}}-d \bar{a} h^{\mathrm{r}}$.

25. Dutch sources show that, in 1762-1763, Mergui and, most likely, Tenasserim were under the Siamese. See Lorna Dewaraja, The Kandyan Kingdom of Sri Lanka, 1707-1782 (Colombo: Lake House, 1988), p. 116, n. 131. A Burmese royal chronicle contradicts this, effectively implying that Burmese control over the Tenasserim coastline was unbroken since 1760 .

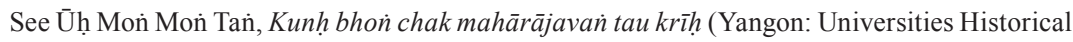
Research Centre, 2005), vol. 1, pp. 268 and 282.

26. Ms. from the Zetawun monastery, f. $k \bar{u}^{\mathrm{r}-\mathrm{v}}$.

27. Mon் Mon் Tan், Kunh bhon், p. 280. Perhaps, this shift was also related to Sāralañkā's association with Kyethtungin Hsayadaw (though it is not mentioned in the testimonies), as Kyethtungin is known to have been granted a royal monastery near Taungbila in 1766.

28. Ms. no. 10551 in UCL, ff. $d h a u^{\mathrm{v}}-d h a m^{\mathrm{r}}$.

29. The second available testimony bears a date of December 1787, while also claiming to be recorded in the reign of King Ngasingu-min (r. 1776-1782), that is, eleven to five years earlier than 1787 (ms. no. 10551 in UCL, ff. $\operatorname{dam}^{\mathrm{r}}$ and $\left.\underset{\operatorname{dham}}{\mathrm{r}}\right)$. The document also states that the testimony was taken after Sāralankā resided in the royal city for fourteen years (f. dham $^{\mathrm{r}}$ ). If this information is correct and if, indeed, Sāralankā was escorted to Ava in 1766 or 1767, the document thus falls between 1780 and 1781 (which corresponds to the reign of Ngasingu-min).

30. The creative work and biography of Mun Ko are almost entirely forgotten. Apparently, none of his works have been published, and, thus, most contemporary scholars of Burmese literature never saw his writings. I have been told that, besides Cetyavamsa, there exist several poems written by Mun Ko. U Thein Lwin, deputy director general of archaeology (Upper Myanmar), personal communication, November 2013.

31. The date 1773 suggests that Mun Ko had access to another testimony of Sāralañkā's that is not available to us.

32. Undated noncataloged palm-leaf manuscript from the collection of $U$ Bo Kay, the late archaeological conservator of Bagan, now kept in the Archaeological Museum, Bagan. The quote from Sāralañkā's testimony appears on folios $c \bar{u}^{\mathrm{v}}-c e^{\mathrm{v}}$ in the Pāli text and on folios cho $^{\mathrm{v}}$ - cham $^{\mathrm{r}}$ in the nissaya.

33. Ariyāvaṃsa Ādiccaraṃsī, Samantacakkhudīpanī kyamh (Yangon: Sāsanā reḥ u ci țțhāna, 1985), p. 398. Ariyāvaṃsa Ādiccaramsī (1766-1834), also known as the Second Monywe Zetawun Hsayadaw, was one of the most erudite Burmese authors of his time. He combined nonscriptural and scriptural knowledge and took particular interest in chronicles, legal texts, and devotional poetry. He was one of the primary official historiographers of the Burmese court in the 1820 s and early 1830 s, and a teacher of several ministers. In spelling Ariyāvaṃsa's title, I follow the historical Burmese manner. 
34. As mentioned above, the manuscript is undated, but was, most likely, copied in the 1760 s or 1770 s and, if so, should have belonged to the first abbot of the monastery who preceded Ariyāvamsa. The nature of reference given by Ariyāvaṃsa in his 1810 message rules out the possibility that he used the "1787" testimony, for the information Ariyāvaṃsa quotes is absent there. Moreover, the "1787" testimony was taken not in the reign of Hsinbyushin but later.

35. It is likely that Sāralañkā was the only candidate for attribution, as no other participants in Siamese missions to Lankāa are known to have resided in Burma.

36. Ms. from the Zetawun monastery, ff. $k \bar{a}^{\mathrm{v}}$ and $k \bar{u}^{\mathrm{r}}$.

37. He stated that he had studied only to the extent of knowing the four päräjikas (the rules that constitute one of the most basic observances in the sargha). Ms. from the Zetawun monastery, f. $k \bar{a}^{\mathrm{r}}$. Pārājika rules cover a group of transgressions of monastic discipline that lead to a loss of monastic status: noncelibacy, theft, murder, and false claims of supramundane spiritual attainments.

38. The Burmese term pa shyu used in the text could signify both. Ms. from the Zetawun monastery, f. $k \bar{u}^{\mathrm{r}}$. It is not clear if that entailed posing as Muslims.

39. Borommakot (r. 1732-1758) was succeeded by Utumphon and in two months by Ekkathat (r. 1758-1767).

40. This translation is based on the reading of the phrase in question as ca khyvam man kui sā chak ra sañ̃n. The second syllable could also be read as chvam, which with some degree of imagination might be translated as "the king has personally offered rice," but the syntax is unusual and the translation does not fit the context.

41. Ms. from the Zetawun monastery, f. $k \bar{u}^{\mathrm{r}}$.

42. Ms. no. 10551 in UCL, f. $d \bar{a} h^{v}$. Sāralañka did not try to reconcile the claim about the choosing of monks of ten years' standing with the chronology he had provided for himself and, as he did previously, testified that he had been ordained less than ten years before departure for Lañkā.

43. Ibid., f. $d h a^{\mathrm{r}}$.

44. Ibid., ff. $d h a^{\mathrm{v}}-d h \bar{a}^{\mathrm{r}}, d h a u^{\mathrm{r}-\mathrm{v}}$.

45. See Blackburn, Buddhist Learning. For a comparative case of such dynamics, see the chapter by Amy Holmes-Tagchungdarpa in this volume.

46. In the 1767 testimony, Sāralañkā mentioned that Mahinda stūpa and the stūpa enshrining Buddha's nails in Tissavihāra in Anurādhapura were similar in shape to Shwezigon in Bagan, that Mahiyangana cetiya (shrine complex) and Dīghāvāpī cetiya were similar in shape to Shwedagon in Yangon, and that the landscape of Anurādhapura was similar to the old city of Bagan with its multitude of ancient temples and overgrown terrain. The 1773 testimony, as quoted by Mun Ko, compared Mahāmaṅgalavihāra in Trincomalee to Shwezigon in Bagan; the same comparison was also reproduced in the "1787" testimony. This third document also featured other comparisons, some of them revised as compared to the 1767 testimony.

47. Ms. no. 10551 in UCL, f. $d h o^{v}$.

48. For a discussion of this curriculum, see Alexey Kirichenko, "Local Sources and MicroRegional Perspectives on the Histories of Buddhism in Nyaungyan and Konbaung Myanmar," paper given at the "New Perspectives on the History of Myanmar" conference, University of Yangon, July 24, 2014.

49. Ussaro, Hamsavatī Chañ phrū rhañ areh tau pum mau kvamh udānh, edited by Ūh Tuiḥ Hla (Yangon: Universities Historical Research Centre, 2006), pp. 137-148. 
50. Ms. no. 10551 in UCL, f. $d h e^{\mathrm{r}}$.

51. The list appears in a message sent by Ñānābhivaṃsa to Badon-min. Ñāṇābhivaṃsa, Ameh tau phre (Yangon: Sāsanā reh u ci țthāna, 2012), pp. 176-189. It is referred to, for example, in Than Tun, "The Influence of Occultism in Burmese History with a Special Reference to Bodawpaya Reign,” Bulletin of the Burma Historical Commission 1.2 (1960): 117-145.

52. The Burmese term kyañnh used in the document does not properly differentiate between the two possible locations.

53. In the 1780s and 1790s, Thiri Sandarat was one of the key agents in Burma's external communications, traveling to India and Lañkā on the instructions of Badon-min. His origins and biography are not clear so far, but I assume that he was most likely either an Indian or an Armenian. The name Punshi might be a scribal error for Munshi.

54. Palm-leaf manuscript no. 5747 in UCL, ff. $t \bar{u}^{\mathrm{v}}-t o^{\mathrm{r}}$.

55. The same pattern of restoring one's collections to their former contents has guided other historical manuscript acquisition efforts in Buddhist Southern Asia. For example, in 1755 the Kandyan court requested from Ayutthaya seventy-five Pāli works lost in Lañkā. These (and some twenty more) were delivered by the 1756 mission in which Sāralańkā participated. In 1789, a similar request for thirty-three Pāli texts was made to Amarapura. See Oscar von Hinüber, "Remarks on a List of Books Sent to Ceylon from Siam in the 18th Century," Journal of the Pali Text Society 12 (1988): 175-183; Ñānābhivaṃsa, Ameh tau, p. 331. The objective to strengthen local tradition through external contacts does not imply that no external borrowing or influence occurred as a result. As amply demonstrated by the fact that 170 mostly new manuscript copies were delivered to Amarapura from Nabadwip in 1785 instead of the 48 replacement texts requested, Buddhist interactions in eighteenth-century Southern Asia likely promoted the traffic of new artifacts and practices though did not result in the establishment of shared networks related to religious orders.

56. Ñāṇābhivamisa, Amẹ tau, p. 340.

57. The only extant royal court on the island at the time was in Kandy rather than Anurādhapura, but the Burmese likely framed their connection with the island in terms of Anurādhapura since it was a well-known early royal Buddhist center on the island. At that time it was to some extent administered from the Kandyan royal court with the assistance of subregional intermediaries on the island.

58. Palm-leaf manuscript no. 6093 in the research library of the Ministry of Religious Affairs, Yangon, ff. $d h o^{\mathrm{v}}-n i^{\mathrm{r}}$.

59. Ñānābhivaṃsa, Ameh tau, p. 331.

60. Ibid., pp. 324-326, 331-332, and 340-341.

61. I follow Anne Blackburn in her use of the term "symptomatic" in Blackburn, "Sīhaḷa Sangha and Lañkā," p. 318.

62. See further, Blackburn, "Buddhist Connections."

63. At the same time, although the practical outcomes of Nānāahbivamisa's grand plans were more limited, they helped to lay the foundation for more substantial cooperation between Buddhist elites of Burma and Lankā achieved by the late nineteenth century.

64. A Burmese translation of this letter referred to Qing and Burmese sovereigns as being equals. For the translation of Qianlong's letter, see Ñāṇābhivaṃsa, Ameh tau, pp. 211-212. For an official account of the reception of princesses, see Mon Moń Tań, Kunh bhon, vol. 2, pp. 62-64. For discussion of this diplomatic activity, see Sylvie Pasquiet, "Trois princesses chinoises à la cour d'Amarapura: Petite histoire d'une mystification diplomatique (1790)," in 
Études birmanes en hommage à Denise Bernot, edited by Pierre Pichard and François Robinne (Paris: Presses de l'École française d'Extrême-Orient, 1998), pp. 245-259; and U Thaw Kaung, "Bogus Chinese Envoys, Spurious Chinese Princesses at the 18th-Century Myanmar Royal Court," Journal of Burma Studies 18.2 (2014): 193-221.

65. Ñānāahivaṃsa, Ameh tau, pp. 213-214.

66. Ibid., p. 308.

67. Ibid., p. 309. The story of Kangxi's arrival at Mt. Wutai is detailed in a chronicle compiled under the supervision of the Second Monywe Zetawun Hsayadaw. Undated palm-leaf manuscript of the fourth bundle of Monywe chronicles in the Zetawun monastery, ff. $j \bar{a}-j i$. I have not yet been able to trace the origins of this particular narrative.

68. A-ch'angs are a Tibeto-Burman ethnic group from Yunnan. Ñāṇābhivaṃsa, Ameh tau, pp. 601-602.

69. An attempt at a closer examination of this mix of actors is made, for example, in Alexey Kirichenko, "Political Expansion, Maritime Trade, and Religious Practitioners on the Move: Revival of Interactions between Burma and Lanka in the Late Eighteenth and Early Nineteenth Centuries," lecture given as a part of the Nalanda-Sriwijaya Lecture Series, Nalanda-Sriwijaya Center, Institute of Southeast Asian Studies, Singapore, May 21, 2012.

70. Thongchai Winichakul, "Writing at the Interstices: Southeast Asian Historians and Postnational Histories in Southeast Asia," in New Terrains in Southeast Asian History, edited by Abu Talib Ahmad and Tan Liok Ee (Athens: Ohio University Press, 2003), p. 23; Willem van Schendel, "Geographies of Knowing, Geographies of Ignorance: Jumping Scale in Southeast Asia," Environment and Planning D: Society and Space 20 (2002): 647-668; James C. Scott, The Art of Not Being Governed: An Anarchist History of Upland Southeast Asia (New Haven: Yale University Press, 2009).

71. See, for example, C. Patterson Giersch, Asian Borderlands: The Transformation of Qing China's Yunnan Frontier (Cambridge, MA: Harvard University Press, 2006); C. Patterson Giersch, "Grieving for Tibet: Conceiving the Modern State in Late-Qing Inner Asia," China Perspectives 3 (2008): 4-18; John E. Herman, Amid the Clouds and Mist: China's Colonization of Guizhou, 1200-1700 (Cambridge, MA: Harvard University Asia Center, 2007), esp. pp. 103-143.

72. Definitions are given in Christine E. Dobbin, Asian Entrepreneurial Minorities: Conjoint Communities in the Making of the World-Economy, 1570-1940 (London: Curzon Press, 1996); Edward A. Alpers, The Indian Ocean in World History (Oxford: Oxford University Press, 2014); and Sebouh David Aslanian, From the Indian Ocean to the Mediterranean: The Global Trade Networks of Armenian Merchants from New Julfa (Berkeley: University of California Press, 2011). These provide a few representative examples of the extensive body of research on Asian entrepreneurial communities.

73. See, for example, Ismail Alatas' contribution to this volume as well as Eric Tagliacozzo and Wen-Chin Chang, eds., Chinese Circulations: Capital, Commodities, and Networks in Southeast Asia (Durham: Duke University Press, 2011); Jianxiong Ma and Cunzhao Ma, "The Mule Caravans as Cross-Border Networks: Local Bands and Their Stretch on the Frontier between Yunnan and Burma," in Myanmar's Mountain and Maritime Borderscapes: Local Practices, Boundary-Making and Figured Worlds, edited by Su-Ann Oh (Singapore: ISEAS Publishing, 2016), pp. 237-257; Engseng Ho, Graves of Tarim: Genealogy and Mobility across the Indian Ocean (Berkeley: University of California Press, 2006); and Ulrike Freitag, "Introduction: Inter-Oceanic Migrations from an Indian Ocean Perspective, 1830s to 1930s," in 
Connecting Seas and Connected Ocean Rims: Indian, Atlantic, and Pacific Oceans and China Seas Migrations from the 1830s to the 1930s, edited by Donna R. Gabaccia and Dirk Hoerder, Studies in Global Social History 8 (Leiden: Brill, 2011), pp. 67-78.

74. See, for example, Michael Feener and Terenjit Sevea, eds., Islamic Connections: Muslim Societies in South and Southeast Asia (Singapore: Institute of Southeast Asian Studies, 2009); Michael Laffan, The Making of Indonesian Islam: Orientalism and the Narration of a Sufi Past (Princeton: Princeton University Press, 2011); Christopher M. Joll, "Islam's Creole Ambassadors," in The Ghosts of the Past in Southern Thailand: Essays on the History and Historiography of Patani, edited by Patrick Jory (Singapore: NUS Press, 2012), pp. 129-146.

75. Brian Bocking, Phibul Choompolpaisal, Laurence Cox, and Alicia M. Turner, eds., $A$ Buddhist Crossroads: Pioneer Western Buddhists and Asian Networks, 1860-1960 (London: Routledge, 2014).

76. Note, however, that there is an ongoing research project by Anne M. Blackburn, "Making Buddhist Kingdoms across the Indian Ocean, 1200-1500."

77. Anthropological work on contemporary Tai Buddhists in Déhóng Prefecture of Yunnan suggests that even now the participation of Tai monks from the area in ordination and educational networks in Myanmar does not displace indigenous Tai lay and monastic formations not recognized by official Burmese monastic institutions. See Takahiro Kojima, "Tăi Buddhist Practices on the China-Myanmar Border," in Myanmar's Mountain and Maritime Borderscapes, edited by Su-Ann Oh, pp. 369-387.

78. See Alexey Kirichenko, "Dynamics of Monastic Mobility and Networking in Seventeenth- and Eighteenth-Century Upper Burma," in Buddhist Dynamics in Premodern and Early Modern Southeast Asia, edited by D. Christian Lammerts (Singapore: Institute of Southeast Asian Studies, 2015, pp. 333-372); Alexey Kirichenko, "The Thathanabaing Project: Monastic Hierarchies and Colonialism in Burma," in Theravada Buddhism in Colonial Contexts, edited by Thomas Borchert, Routledge Critical Studies of Buddhism (London: Routledge, 2018, pp. 138-161); Alexey Kirichenko, "Change, Fluidity, and Unidentified Actors: Understanding the Organization and History of Upper Burmese Samgha from the Seventeenth to Nineteenth Centuries," paper presented at the joint meeting of the Association for Asian Studies and the International Convention of Asia Scholars, Honolulu, Hawai ${ }^{i}$ i, April 3, 2011.

79. Blackburn, "Sīhaḷa Sanggha"; Blackburn, Buddhist Learning.

80. See Malalgoda, Buddhism in Sinhalese Society; Blackburn, Buddhist Learning. 


\title{
CHALLENGING ORDERS
}

\author{
Tarīqas and Muslim Society in Southeastern \\ India and Laìkā, ca. 1400-1950
}

TORSTEN TSCHACHER

On June 24, 1889, a reader's letter was published in the Colombo-based Muslim weekly Muslim Nécan. Its author complained of magical practices that were supposedly going on in some zāwiyas (Sufi lodges) in Colombo, rhetorically asking whether "such magic practices belong to our religion?"1 Such criticism of Sufi institutions and practices is hardly surprising in the context of nineteenthcentury Muslim discourse. What is noteworthy is that the author of the letter identified himself as "a Qādirī Muslim," that is, as a member of a specific Sufi order ( $\operatorname{tar} \bar{q} q)$. And it was clear to his audience that the Sufi lodges condemned in the letter were not general Sufi institutions but themselves connected with a particular tarīqa, the Shādhiliyya, a Sufi order that had been introduced to Lank $\bar{a}^{2}$ in the middle of the nineteenth century. Not surprisingly then, followers of the Shādhiliyya accused the writer of the letter and even the editor of the newspaper that published it of slandering their tariqa unnecessarily for what was, in their eyes, a minor incident involving some uneducated people. ${ }^{3}$ But what precisely did it mean to be part of a Sufi tarīqa in South India and Lankā in the nineteenth century? What kind of institutions were these tariqas? What role did they play in Muslim society and in the history of Islam in the region? And how, if at all, did their constitution change over time? Despite the ubiquity of Sufi orders in historical accounts of Muslim societies in the region, there is surprisingly little research on the social history of tarīqas in southeastern India and Lañkā. ${ }^{4}$

This is particularly surprising since the Sufi "order," or tariqqa, has often been treated as the single most important institution in South Asian Sufi traditions, if not in South Asian Islam as a whole. There are few treatments of the history of Islam in South Asia that do not assume the centrality of different tarīqas, an assumption evidenced in the casual references to collectives, such as Chishtīs or Naqshbandīs, or to "orders" and "brotherhoods" in general as a 
central part of Muslim religious life in South Asia. Yet, despite the impression of familiarity with Sufi orders that these accounts suggest, precisely what kind of institution a Sufi "order" in South Asia is supposed to have been is far from clear. As Carl Ernst and Bruce Lawrence state in their magisterial study on the Chishtiyya, "We don't understand [Sufi orders], or at least we haven't figured out how to understand them as historical developments." I would suggest that the centrality of tariqas in the history of South Asian Islam is more apparent than real, a product of historiographical preferences in terms of themes and sources. ${ }^{6}$ From the perspective of postpartition South Asia, Islam has been treated predominantly as a political phenomenon, with the history of Islam in South Asia being written primarily as a history of empires, dynasties, and states. ${ }^{7}$ In this narrative, the Sufi "orders" serve as a kind of parallel structure to the Muslim state-what empires and dynasties are in the "secular" domain is constituted by tariqas and silsilas in the spiritual realm. Not surprisingly, Sufi "orders" are usually discussed with regard to how they related to the Muslim state, on the one hand, and to non-Muslims and the "Islamization" of South Asia, on the other hand. That this narrative seems so convincing is not simply because of its ubiquity but because it is rooted in the sources that have usually been used to write the history of Islam in South Asia - that is the Persian, Arabic, and Urdu texts that were composed by the elites of Muslim states, in which the relationship of worldly and spiritual "authority" (wilāya), of sultan and Sufi saint, was an established trope. ${ }^{8}$

Any investigation of South Asian Islam and Muslim societies that is genuinely interested in moving away from state-centric (which means, in most cases, Delhi-centric) narratives will therefore also have to question the role of the tariqa as a supposedly central institution of Muslim religious life outside the circles of imperial political elites. Yet, at least as far as the Tamil-speaking parts of South India and Lankā are concerned, such a questioning has not happened. If anything, only the template of Sufi orders that are listed is changed: if, in northern India, the Chishtiyya, Suhrawardiyya, and Naqshbandiyya are identified as the most important țariqqas, the Qādiriyya, Rifā'iyya, and Shādhiliyya are mentioned instead - there is no questioning of the centrality accorded to conventional ideas of the Sufi "order" in local Muslim society and history. This chapter aims toward initiating a discussion on the social role and constitution of Suf "orders" in South India and Lankkā between the sixteenth and nineteenth centuries by reviewing the actual evidence in Tamil and Arabic sources from the region. Proceeding from the nineteenth-century encounter of the by-thenwell-established Qādiriyya with the newly introduced Shādhiliyya, I discuss the presence of Sufi lineages, practices aimed at the recollection of tariqqa identities, and patterns of authority and controversy among Sufis in South India and Lankā. As I hope to show, there is little to suggest that Sufi "orders" were unchanging elements of Muslim life in the history of the region. Although localized teaching lineages transmitting Sufi thought were certainly part of Muslim 
society from an early stage, there is little evidence for clear-cut tarīqa identifications among these lineages or institutions that could be clearly linked with specific orders. By contrast, the rise of Qādirī and Rifā ‘⿳亠 identities in the region in the seventeenth and eighteenth centuries seems to be more closely related to horizontal networks than to vertical lineages. Only in the mid-eighteenth century do patterns emerge that integrate vertical lineages with the horizontal networks in patterns assumed to be characteristic for Sufi orders, raising the question of what social processes led to change in the organization of Sufi networks and lineages.

\section{LINEAGE}

At the center of the notion of the Sufi order stands the idea of the lineage (silsila), created by the initiation (bay'a) of a disciple (murid) by a preceptor (murshid) that allows the transmission of teachings as much as the power of blessing (baraka) of the preceptor across generations. ${ }^{9}$ What is identified as a Sufi order in any given context is thus generally a network of lineages tracing their traditions back to the same eponymous master. In the case of the Shädhiliyya in nineteenth-century South India and Lankāa, the connection between lineage and order was particularly salient. The Shādhiliyya had not only been introduced very recently, but, for the whole of the nineteenth century, it looked back to a single origin in Mekka and only a few acts of transmission into the region. ${ }^{10}$ For South India, the person credited with the first act of transmission is one Abū Bakr Miskīn (d. 1872) from Kayalpattinam, an important center of Muslim religious life in South India and a stronghold of the Qādiriyya order. Abū Bakr Miskīn was initiated into the Shādhiliyya while on pilgrimage to Mekka. When he returned to his homeland, the new order seems to have spread rapidly. The introduction to Lañkā is less clear. Some websites claim that a certain Sayyid Aḥmad b. Șāliḥ al-Yaman̄̄ established the first Shādhilī lodge in AH 1284 (1867-1868 CE), but other sources claim that three merchant brothers from Galle were first initiated into the order in 1846. Within a few years, the order spread in the southern parts of the Madras Presidency and the southwestern region of Lankā. Over time, individuals from the region would come to travel to the Middle East to seek their own independent initiation into the order, the most important of them being the gem merchant and politician Mohamed Macan Markar (d. 1952), who is sometimes erroneously credited with being the first to introduce the Shādhiliyya to Lañkā in the early twentieth century. ${ }^{11}$ The fact that the presence of the Shādhiliyya in the region goes back to the efforts of only a few individuals has important repercussions for the order and its image in the nineteenth century, one that, as we shall see, it shared with its contemporaneous Qādirī contenders. For what was transmitted was in effect not the Shādhiliyya as a whole, but only one particular branch of it known as the Fāsiyya, after its founder, Muḥammad al-Fāsī (1803/1804-1872), who personally initiated Abū 
Bakr Miskīn in Mekka. Born in Fez in Morocco, al-Fāsī had become a follower of a revivalist Shādhilī branch, the Darqāwiyya, which was spreading in the Maghreb and the Ottoman Empire at that time. This provided the Fāsiyya with cohesion both through the common memory of its relatively recent origins, but also through the commonality of ritual that came along with it. ${ }^{12}$ The link created between al-Fāsī's lineage and its South Asian followers has since been re-created repeatedly by visits of al-Fāsī's descendants to Sri Lañkā and South India, beginning with his son and successor Shams al-Dīn al-Makkī. ${ }^{13}$

At first glance, the Qādiriyya had a far less uniform presence in nineteenth-century South India and Lankāa. Indeed, its very ubiquity seems to make it impossible to arrive at any clear picture of its role in local Muslim society, not to speak of its origins. It often appears as if the Qādiriyya has been around ever since Muslims came to settle in the region. Yet, much as in the case of the Shādhiliyya, during the nineteenth century the local Qādirī landscape was dominated by individual lineages, some more visible than others, that effectively operated on their own even as they claimed a common Qādirī background. Perhaps the most important of these was the 'Arūsiyya, named after Sayyid Muḥammad b. Aḥmad, better known as Māppiḷlai Leppai or Imām al-'Arūs (1816-1898) of Kilakkarai near Ramanathapuram, one of the most prolific authors of Muslim prose literature in Tamil in the period. Māppillai Leppai traveled widely in India and especially Lañkā, attracting students and founding mosques and hospices. Although his lineage of initiation was local rather than Middle Eastern, it included several highly regarded Sufis from elite backgrounds. Through his own preceptor and father-in-law, K̄̄llakkarai Taykā Șāhị (1778-1850/1851), a noted poet, Māppiḷlai Leppai traced his lineage to Shaykh 'Umar Walī (1748-1801) of Kayalpattinam and Sayyid Muhammad Bukhārī Tannal (1731/1732-1792/1793) of Kannur in Kerala. ${ }^{14}$ With both the Qādiriyya and the Shādhiliyya, the nineteenth century presents us with precisely the institutional structures that we have come to expect of Sufi "orders": clearly delineated spiritual lineages (silsila) linked up to a larger common "order" (țarīqa) and identified by compounding the names of both, such as Qādiriyya-'Arūsiyya or Shādhiliyya-Fāsiyya.

Though the nineteenth century may present us with a textbook image of Sufi orders in South India and Lankā, a closer look at the available sources would suggest that this state of affairs was of rather recent origins. Whereas the Shādhiliyya is widely known to have been a nineteenth-century introduction to the region, the Qādiriyya is generally believed to have been the dominant Sufi order in the region for centuries before that. The vast majority of saints venerated in the region are claimed to have some connection to the Qādiriyya. Indeed, 'Abd al-Qādir al-Jīlān̄̄ is even claimed to have visited Lañkā personally. ${ }^{15}$ But a closer look at the available evidence suggests that there is little apart from modern hagiographies to suggest a widespread presence of Qādirī networks in the region before the seventeenth century. For example, although 
names suggesting Qādirī devotion, such as 'Abd al-Qādir or Muḥȳi al-Dīn, are common in the town of Kayalpattinam today, none of the more than seventy individuals recorded in local epitaphs of the fourteenth to sixteenth centuries mentioned in the works of Desai and Shokoohy has such a name. The first listed instance of "Qādirī" names in Kayalpattinam epitaphs is of a certain Sayyid Muhyi al-Dīn b. Sayyid 'Abd al-Qādir, dating to $1796 .{ }^{16}$ The situation seems similar in other towns: none of the other pre-seventeenth-century Arabic and Persian inscriptions from Tamil Nadu listed by Desai records individuals with names that could be linked to a tariqqa. ${ }^{17}$ The two earliest Islamic poems in Tamil, dating to 1572 and 1590, are almost unique in earlier Islamic Tamil literature as they lack a stanza in praise of 'Abd al-Qādir al-Jīlānī in their opening sections. ${ }^{18}$ The first eulogies of the saint appear only in the seventeenth century, and, even with regard to these eulogies, we have to note that Qādirī devotionalism does not necessarily imply the presence of an institutionalized Qādirī order-even one of the main Tamil Shādhilī hagiographies of the nineteenth century begins with a chapter on the life of 'Abd al-Qādir al-Jīlānī. That al-Jīlān̄̄ is part of the silsila of many Sufi orders, not only of expressly Qādirī lineages, makes devotional traditions around al-Jīlānī weak evidence for the presence of an institutionalized Qādirī order. ${ }^{19}$

It would not be correct to say, however, that lineages of initiation played no role or were not mentioned in this period. We have a number of examples, mostly dating to around 1700, where several generations of teachers are mentioned, especially when a teacher was well known, but without mentioning a particular order that was transmitted through such teaching lineages. A good example is provided by perhaps the best-known Muslim religious scholar of the Tamil country in the seventeenth century, Shaykh Șadaqatullāh b. Sulaymān of Kayalpattinam (1632-1703). Although Șadaqatullāh is generally assumed to have been a Qādirī and is frequently mentioned in the Tamil literature of the period, his affiliation to the Qādiriyya does not seem to be mentioned in that literature. It is indeed noteworthy that most present-day Qādirī lineages in the region seem to trace themselves to lineages that entered Tamil Nadu and Lankā during the eighteenth century at earliest and not to Șadaqatullāh. A prime example of this is Māppillai Leppai, who, as already mentioned, traced his initiation to an eighteenth-century preceptor from Kerala rather than to Sadaqatullāh even though he was descended from the latter through both his father and his mother.

It is not that the Qādiriyya or other Sufi orders were absent from the region in the sixteenth and seventeenth centuries. Rather, it seems that affiliation to a specific order was not of particular importance, most probably because individuals were affiliated to several orders and not just to one, or possibly because notions about the meaning of tarīqa affiliation differed from those that are held nowadays. In the process, the precise lineage and preceptors who bundled affiliation to several orders would have become more important than the historically 
more distant orders themselves. One such order whose presence beside the Qādiriyya in South India and Lankā during the sixteenth and seventeenth centuries is strongly suggested is the Shațāariyya, given the strong presence of that order in other parts of the southern Asian littoral, such as Gujarat or Java. The region's most celebrated Muslim saint, Shāh al-Hamīd of Nagore, was a disciple of the Shațāāī preceptor Muhammad Ghawth of Gwalior (d. 1563), though much less is nowadays made of Shāh al-Hamīd's connection to this order than of his additional initiation into the Qādiriyya. As I have suggested elsewhere, it is possible that Sām Shihāb al-Dīn (1634/1635-1709), a younger brother of Shaykh Șadaqatullāh, may have been a disciple of Ibrāhīm al-Kūrānī (16141690) and the latter's teacher, Aḥmad al-Qūshāshī (d. 1661). Although both of these scholars were, like Shāh al-Hamīd, initiated into multiple Sufi tarīqas, al-Qūshāshī is most commonly remembered as a preceptor of the Shațāariyya, whereas al-Kūrānī has been most prominent as a Naqshbandī teacher. ${ }^{20}$ In such contexts of multiple initiation and transmission of orders, it would hardly be surprising if distinct "lineages" became more important as points of identification than those of the broader framework of "orders."

Although specific lineages seem to have played an important role in the early transmission of Sufi discourse in southern India and Lankāa, individual lineages appear to have played a less conspicuous role in the process that first brought not just a particular lineage but a specific Sufi order into the limelight locally. The first clear mention that I have found of a Sufi order in a text from the region is in the Vetapurānam, probably composed in the second quarter of the eighteenth century. In a chapter devoted to becoming a disciple of a Sufi preceptor, the text claims that "it means a great blessing if one takes hold of the Qādiriyya."21 It appears that in this period Qādirī lineages in the region began increasingly to be linked to preceptors operating on the west coast of India, thereby possibly obscuring links to networks of orders, Qādirī or otherwise, that may have existed in the region earlier. The most conspicuous feature of these networks is their close interlinking of the Qādiriyya with another order, the Rifā'iyya. Although this order plays an important part in Muslim religious life in both South India and Lankāa, it has not attracted the same attention from historians as the Qādiriyya, most likely because the Rifā'iyya is far less visible in written sources than the Qādiriyya, and it is most salient among the ranks of itinerant mendicant groups such as the Bawas. ${ }^{22}$ The linkages between such groups and the Rifā'iyya connect this order with the Malangs and similar itinerant groups. Indeed, at Tamil Nadu's largest saint-shrine, the Nagore Dargah, Rifā'îs and Malangs play a central role in the rituals performed during the annual festival. ${ }^{23}$ Already in 1805, the Scottish orientalist John Leyden (17751811), drawing on informants from Malabar, identified "the sect of Ruffii" as a division of the Madāriyya, the order with which the Malangs are most commonly associated. ${ }^{24}$ Lifestyle thereby developed into a marker of affiliation to specific orders so that it is often difficult to establish whether certain individuals 
were indeed formally affiliated with a specific order or were simply identified as members of these orders owing to their living as itinerant mendicants.

Both Rifā'iyya and Qādiriyya have historically spread through the same networks of itinerant Sufis centered on the Lakshadweep archipelago off the Indian west coast. The person who "discovered" the site of Jailani in the nineteenth century was from Androth Island in the Lakshadweep archipelago, as are many of the Rifā' $\overline{1}$ preceptors still active in the region. ${ }^{25}$ The participation of Rifā' $\overline{1}$ dervishes in the celebrations of shrines with strong Qādirī connections, such as Nagore or Jailani, similarly points to the closeness of these two orders. Although it is from these common Qādirī-Rifā' $\overline{1}$ networks that the most prominent Qādirī lineages of the nineteenth century emerged, lineages seem far less salient in these networks as a whole. Furthermore, although family links appear to be rather important in the lineages we have discussed so far, with transmission from father to son or among brothers playing an important role in succession, such kinship links seem to have been of lesser importance to the itinerant Sufis who connected ordinary Muslims throughout South India and Lañkā to preceptors in the western archipelagos of Lakshadweep and the Maldives. This conjecture still requires far more investigation, but the point can be illustrated by taking a look at a silsila contained in a mid-twentieth-century manuscript in my possession (folios 129r-130r). ${ }^{26}$ This manuscript was originally owned by a woman named Balqīs Bī, probably from the vicinity of Nagore, who was initiated into the Qādiriyya in February 1944 by a preceptor from Androth Island. From the silsila, it emerges not only that her preceptor, Sayyid Muhammad Pūkōyā b. al-Sayyid 'Abd al-Qādir, was initiated into both the Qādiriyya and the Rifā'iyya, but that his own preceptor, at least in the Qādirī line, was not his father. Although their itinerant lifestyle allowed these Sufis to connect and integrate a larger region through a single network, this network was held together less by loyalty to particular lineages than by memories and practices that identified all those who participated in this network with the larger order that served as a common signifier.

\section{RECOLLECTION}

In his recent overview of Sufi traditions, Nile Green cautions us not to overlook that, for much of the history of Sufism, Sufi tariqas "were forced to operate largely as conceptual communities in which fellowship was built on bonds of memory and imagination rather than bureaucratic ties and direct communication." ${ }^{27}$ It was the memory of the transmission of authority and practices from master to disciple over the centuries that made it possible for Muslims to identify as members of such institutions as the Qādiriyya or Shādhiliyya, both named after the Sufi master who is supposed to have initiated the chain of transmission.

Given the importance of memory to the constitution of separate lineages into orders, it is actually surprising that one of the main technologies for the 
transmission of such memories, namely, hagiographies of important saints, was almost absent from the repertoire of Islamic writings from southeastern India and Lankā before the nineteenth century. Such hagiographies formed an important part of non-Muslim Tamil literature, however, the most important being Cēkkilār's twelfth-century Periyapurānam, a hagiography of the most important Śaiva saints of the region. ${ }^{28}$ Although Muslim authors adopted the genres and conventions of Tamil literature and apparently especially of Śaiva literature, they focused their attention almost exclusively on the life of the Prophet and his family. For the most part, references to Sufi saints before the nineteenth century were limited to short stanzas in praise of 'Abd al-Qādir al-Jīlānī or (rarely) other saints at the beginning of longer poems. Thus, Sām Shihāb al-Dīn's Rasūl mālai, more than a fifth of which consists of stanzas in praise of scholars and savants of Islam from the Prophet to the poet's own family, lists only five saints connected with establishing Sufi orders: al-J̄̄lānī (stanza 76), al-Suhrawardī (77), al-Rifā'‘̄ (79), al-Shādhilī (89), and al-'Aydarūs (93). ${ }^{29}$ Until the late eighteenth century, only 'Abd al-Qādir al-J̄̄lān̄̄'s life was made the subject of occasional hagiographical texts, and none of these was in the esteemed kappiyam genre in which the life of the Prophet and his family had been told since the late sixteenth century. ${ }^{30}$ Long poems in the kappiyam genre concerning the hagiographies of important Sufis were not composed before the early nineteenth century, when there was a sudden efflorescence of such poems about al-Jīlānī (three poems dating to 1810, 1814, and 1816) and local saints (the Tirukkāraṇappurānam on Shāh al-Hamīd of Nagore of 1812, and the Tịnvilakkam on Sayyid Ibrāhīm of Ervadi of 1821). ${ }^{31}$

Things began to change rapidly with the adoption of print by Tamil Muslims from the 1840s onwards. Not only were further kāppiyam poems composed, but publishers increasingly printed poems in praise of both local and Middle Eastern saints. By the end of the nineteenth century, the extension of narrative prose in Tamil also affected the publication of hagiographies, including those of important Sufis. The first prose texts seem to have been composed in honor of local saints, especially Shāh al-Hamīd of Nagore, but it is noteworthy that among these earliest prose texts we find two Shādhilī hagiographies, Hidāyat al-Sālikīn fì Takhlīs al-Hālikīn (1898) by Muhammad Ismā'īl of Nagapattinam, and Nafahāt al-Anbar fĭ Manāqib al-Quṭb al-Akbar (1902) by Nūḥ b. 'Abd al-Qādir of Kayalpattinam (1830/1831-1905/1906), a well-known scholar and author. ${ }^{32}$ Shādhilī authors seem to have quickly adopted the technology of print for their own purposes: a short poem in praise of al-Shādhilī had already been published in 1871, and, by 1914, a full-fledged kappiyam poem titled Cātulināyakam had been composed on al-Shādhilī. ${ }^{33}$ But Shādhilī authors were not the only ones who competed for space in the developing market for Muslim publications in Tamil. Thus, in 1915, a printing press in Madras issued a volume containing Arabic panegyrics (composed by the Qādirī Māppill lai Leppai) and a hagiography of Mu'īn al-Dīn al-Chishtī as well as a collection 
of stories about important Chishtī saints, though the Chishtiyya never attained the same popularity among Tamil-speaking Muslims as the Qādiriyya and the Shādhiliyya. ${ }^{34}$

Literary hagiographies were only part of the process of remembering and commemorating the Sufi masters of the past; stories and biographies also circulated orally among disciples and supporters of Sufi lineages and networks. The pattern of the production of hagiographic texts is nevertheless revealing. Literary texts brought with them prestige, especially if they were composed in highly regarded genres like the kapppiyam, as well as aiding the creation of "interpretive communities" that shared a common understanding of their lineages and networks as being grounded in an accepted recollection of the deeds and lives of earlier preceptors. ${ }^{35}$ In this context, the historical development of the textual recollection of Sufi saints in the Tamil region is revealing. Until the late seventeenth century, it seems that Muslims in the Tamil-speaking parts of South India and Lañkā were not particularly concerned about the creation of hagiographical accounts about earlier Sufi masters - the Prophet and his family were the prime focus of narrative poetry. When hagiographic writing emerged around 1700, it focused almost exclusively on 'Abd al-Qādir al-Jīlānī, probably reflecting the rise of the regionwide Qādirī network spreading from the western islands in this period. It is only in the context of the nineteenth century that hagiographies of Sufi saints start to form a major element of Muslim writing in Tamil. It is not surprising that the same period saw Qādirīs discuss the propriety of certain stories about 'Abd al-Qādir al-J̄̄lānī in the new medium of the newspaper or that some of the earliest catalogs of Sufi orders in Tamil are to be found in the Shādhilī hagiographies. ${ }^{36}$ As more Sufi orders and lineages came to compete for followers in South India and Lankā, textual production increased and fed into the development of a print market for Muslim publications.

Yet orders were not only constituted and defined through a recollection of their past - the definition of certain practices in the present proved to be of similar importance, especially as many of these practices were themselves connected to the recollection of the place of the tariqa and lineage in the divine order of things. To quote Nile Green again, "the method of master-disciple learning and the reading of training texts ensured some degree of standardization in the doctrines and practices held by fellow members of the same brotherhood." ${ }^{37}$ Nineteenth-century Sufi discourse in South India and Lankā placed a heavy emphasis on the practices enjoined by the tariqqa in question. The connection between tarīqa and practice is particularly salient in those practices that are limited to specific Sufi orders, such as the performance of litanies for recollection of God, the Prophet, and the saints, such as dhikr, wird, or rätib. Many of the important nineteenth-century lineages performed their characteristic litanies, such as the Rātiba Jalāliyya of the Qādiriyya-'Arūsiyya composed by Māppiḷ̣ai Leppai or al-Fāsī’s Șalāt al-Yāqūtiyya in the Shādhiliyya-Fāsiyya. 
Hagiographies were similarly not limited to extolling the learning, miracles, and lineages of the respective saints and preceptors. Muhammad Ismā'‘̄l's collection of hagiographies of important Shādhilī preceptors is immediately followed by a 130-page tract on the meaning of tariqa and the performance of $d h i k r$, and then by about 120 pages of wird and other types of Arabic poems for ritual recitation. Thus, more than half of what is purportedly a hagiography is actually filled with information on how to be a practicing Shādhilī. Similarly, in the manuscript of a Qādirī woman of the 1940s that I have mentioned above, a short tract is devoted to the performance of dhikr in accordance with Qādirī "customs" (ādāb). In this way, the nineteenth-century lineages are comparable to what Jamil Abun-Nasr refers to as "Sufi brotherhoods," that is, centralized and exclusive communities of Sufis following only the distinctive rules and practices set down by the brotherhood's founder. This similarity is not surprising, especially in case of the Fāsiyya. Many of the "brotherhoods" discussed by Abun-Nasr formed in northern Africa and provided the context in which the Darqāwiyya, the branch of the Shādhiliyya to which the Fāsiyya belongs, developed. Furthermore, the development of such exclusive Sufi communities was itself a fairly recent development, usually not dating back beyond the eighteenth century. ${ }^{38}$

It is therefore unsurprising that the connection between practice and a specific order was not always so close. This is not to say that practice and notions about the propriety or impropriety of certain practices played no role in earlier Sufi networks and that the emphasis on proper practice in the nineteenth century is part of a process of "Islamization" in which an earlier, somehow less "Islamic" and compromised situation is replaced by closer attention to proper religious behavior and an increased reception of Arabic texts. Rather, what seems to have been missing in the earlier period was the way in which "order" and "practice" defined and reinforced each other, with an order being defined by particular practices and particular practices being the domain of a specific order. In contrast, some of the earlier Islamic nonnarrative religious literature in Tamil, although drawing profusely on Middle Eastern Sufi authors, does not seem to proclaim its tarīqa background in any meaningful manner. Thus, Maḥmūd b. Muḥammad Leppai's early eighteenth-century dogmatic tract

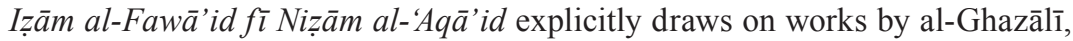
al-Nawawī, Ibn al-'Arabī, al-Jīlī, al-Burhānpūrī, and al-Qūshāshī but does not seem to ally with any particular order. ${ }^{39}$

The first texts that explicitly proclaim their affiliation with the Qādiriyya, in contrast, appear rather different from prose tracts like Izām al-Fawā'id. These are poems often dubbed "songs of gnosis," or meyñ̃ānap pātalkal (sing. meyñ̃ānap pātal) in Tamil. ${ }^{40}$ The peculiarity of these songs is that they combine the vocabulary of a Śaiva poetic tradition, so-called Siddha (Tamil cittar) poetry, with esoteric Islamic discourse in a dense and as yet insufficiently studied manner. The already mentioned Vétapurānam clearly draws on this tradition, whose author is significantly said to have been a disciple of the author of 
Izām al-Fawā'id. Similar poetry is connected to later authors with clear-cut Qādirī affiliation, such as Shaykh 'Umar Walī and Kīlakkarai Taykā Ṣāhib. The latter was not only the preceptor of Māppiḷai Leppai, but also the teacher of the most important exponent of this style of Islamic Tamil poetry, Kunanikuti Mastān Șāhib. Although these songs drew considerable criticism from some quarters in the nineteenth century-the Vétapurānam was apparently refuted in AH $1272(1855 / 1856 \mathrm{CE})$ by a convocation of Islamic religious scholars ${ }^{41}$ — it is erroneous to characterize them as the product of a weakly Islamized convert society, as is still sometimes done. ${ }^{42}$ A widely read scholar such as Māppillai Leppai felt no inhibitions about quoting poems by Kuṇañkuṭi Mastān Șāḥib in his religious manuals, and such poems are commonly encountered in Qādirī contexts in South India and Lañkā. ${ }^{43}$ The 1940s manuscript of a Qādirī devotee that I have referred to similarly contains not only texts recording the woman's lineage and proper Qādirī devotional exercises, but also the text of the Pismil Kuram, a famous meyñ̃̃anap pātal by the seventeenth-century poet Pīr Muhammad of Takkalai. Apparently, Balqīs Bī considered such poetry and its interpretation to be as fundamental a part of her religious life as the performance of dhikr or the commemoration of her preceptor.

Thus, the situation observed in South India and Lankā casts doubt on common assumptions made in studies of Sufism in South Asia and elsewhere that Sufi orders played an important part in the Islamization of the general Muslim population. ${ }^{44}$ There seems little evidence that the Qādiriyya or any other Sufi order aided early processes of Islamization, though for most Muslim authors of the period Sufism was a fundamental part of Islamic practice. Rather than the Qādiriyya simplifying Sufi discourse in vernacular poetry for an uneducated audience, it appears that part of the appeal of the Qādiriyya was provided precisely by the opposite process of drawing local Muslims into an "interpretive community" capable of decoding the complex esoteric poetry that was popular in Qādirī circles and that reached beyond the prose treatises on proper practice that circulated in more localized lineages. ${ }^{45}$ Interpretation of such poetry thus came to be a practice that defined the Qādirī networks of the period much as Arabic litanies were to do in the second half of the nineteenth century. Although there were no formalized or even state-backed institutions among local Muslims that could inculcate a set of interpretive practices through an educational curriculum, as was the case in the rise of the Siyam Nikāya in eighteenth-century Lankan monasticism, it is clear that meyñ̃nannap pātalkal and the capacity to interpret them in an Islamic framework were part and parcel of the extension of integrative and assimilative networks, networks that, in the course of the eighteenth and nineteenth centuries, increasingly came to define themselves by propagating specific practices of interpretation and recollection, thereby demarcating their boundaries and highlighting their individuality, which in turn allowed followers to identify with particular practices and lineages propagated within the network and thus to distinguish it further from other networks. 


\section{AUTHORITY}

Although the intersection of initiation lineages with certain practices may have helped to define these lines more clearly, this alone would not have been enough to integrate distinct lineages in different localities into common patterns of practice and identity across space as usually associated with the term "order" (tariqa). The barriers of communication and limits of de facto authority meant that in many parts of the Muslim world, Sufi tariqqas were linked, if at all, by reproduction of a common memory and identity. But in order for different lineages to become, again in the words of Nile Green, "mechanisms of the reproduction and standardization of tradition," $" 46$ they required more than just an awareness of those lineages and sets of defining practices. They required networks through which their ideas and practices could circulate. These networks needed to command a certain authority to be able to extend themselves into new contexts, ensure adherence of individual groups and lineages to the network, and contest the claims of rival networks. In order to understand how authority was established in Sufi networks in southern India and Lankā, let us turn now to consider developments in the nineteenth century.

In the case of the Shādhiliyya-Fāsiyya, the importance of its network and the speed with which it was able to replicate this network in southern Tamil Nadu and the southwestern regions of Lanka a is remarkable. Although more research is required to be able to map the extension of this network in the course of the nineteenth century exhaustively, it seems likely that a lot depended on individuals like Abū Bakr Miskīn, who brought the order to the region from Mekka. The participation of religious scholars like Nūh b. 'Abd al-Qādir al-Qāhirī, who could support the growth of the network through the production of texts and their distribution via a growing number of printers and booksellers, similarly may have boosted the prestige and appeal of the Shādhiliyya. A third factor may have been the institution of the lodge, or zâwiya. In a region where existing Sufi structures, especially shrines, had a long association with the Qãdiriyya, the Shādhili zäwiyas allowed the order to colonize local spaces effectively by creating distinctly Shādhilī cityscapes.

Yet the Shādhiliyya-Fāsiyya provided its followers with something even more attractive. As part of the Darqāwiyya, a larger movement of traditionalist Sufi revival, the Fāsiyya fit well within the religious context of Muslim societies in South India and Lankā during the later nineteenth century. The Fāsiyya offered more than a revival of Sufi Islam: in contrast to similar movements among the Qādiriyya in the region, the Fāsiyya was directly connected to the Middle East. Al-Fāsī and his successors resided in Mekka, the religious center of the Muslim world, while his branch maintained close connections with larger Shādhilī networks that spread across northern Africa, including Egypt, to Syria. Zāfir al-Madanī (1829-1903), the son of al-Fāsî̀s own preceptor, had 
even initiated 'Abd al-Hamīd II into the Shādhiliyya before the latter became Ottoman sultan. In the late nineteenth century, Egypt and the Ottoman Empire, much more than North India, were the focus of interest among Tamil-speaking Muslims for their role in the revival of Muslim societies, as they were in other Muslim societies across Southern Asia. This interest was fueled by a growing consciousness among South Indian and Lankan Muslims of being part of not only a religious but also a political community defending itself against encroachments by European powers from the Sudan to Aceh and beyond. ${ }^{47}$ That the Shādhilīs were well connected to the Middle East was repeatedly brought home by the announcements they circulated in Tamil newspapers informing the members of the order of the passing away of important preceptors in Egypt and Arabia and the memorial rituals that were to be conducted at local zāwiyas. Similarly, Nūḥ b. 'Abd al-Qādir made it a point to mention that his hagiography of al-Shādhilī was based on "pearls [found] in books from Egypt and Mekka."

If its connections to the religious and political centers of the Middle East gave the Shādhiliyya a good measure of authority when it began spreading in South India and Lañkā in the mid-nineteenth century, Qādirī lineages were able to draw on the already existing authority of a network that had spread throughout South India and Lankā one or two centuries earlier. The linchpin of this network lay also to the west, though much closer to Tamil Nadu and Lankā, in the Lakshadweep and Maldivian archipelagos off the western coast of India and especially on the Lakshadweep island of Androth. It was from there that itinerant Sufi preceptors traveled throughout present-day Kerala, Tamil Nadu, and Lank $\bar{a}$ and initiated disciples into the fold of the two orders they were spreading - the Qādiriyya and the Rifā'iyya. These itinerant preceptors generally claimed to be descendants of the Prophet (Tamil tankal; Malayalam taninal). Although this often went along with a claim that they ultimately hailed from Yemen or Haḍramawt, the appeal and charisma of these taikals were predicated on the fact that their descent from the Prophet endowed them with baraka, blessings from God that allowed them to work miracles. An early eyewitness account of faith in the miracle-working capacities of the people from the western islands with linkages to the Qādiriyya and the Rifā'iyya was given by John Leyden. In autumn 1805, Leyden journeyed from the Indian west coast to Penang on board a native vessel. Among the crew, he noted that "the two Mu'allim's or pilots are Maldivians prodigiously addicted to Sorcery and adepts completely [sic] in the Elmi Dawat [i.e., medicine]." 49 When the vessel was pursued by pirates off the coast of Sumatra, one of the Maldivians went into a trance and began to work charms to make the ship escape the pirates, "all which time he continued in a more ecstatic manner to howl forth Arabic prayers to God, the Prophet, Ali $\&$ the Imams but especially to Ruffii." 50 Yet despite the importance of claims to descent from the Prophet and links to Arabian Sea networks and southern Arabia, this Qādirī-Rifā' $\overline{1}$ combine in the seventeenth to nineteenth centuries 
drew as much authority from is its decidedly vernacular character, embodied in the songs of gnosis, or meyñ̃ānap pätalkal, that spread as part of the network and that tied followers into a common interpretive community.

Even in the case of early localized lineages, the authority that they wielded can sometimes be gleaned from the fact that their members were integrated into the highest levels of Muslim mercantile elites in the region. The most obvious example is the family of Shaykh Șadaqatullāh, whose daughter married the son of the merchant Māmu Nayināan, widely believed to have been the younger brother of the magnate Cītakkāti. One son of this marriage, Leppai Nayin̄ār, became the linchpin of power in the Ramnad kingdom during the 1720 s to 1730s. It is noteworthy that two kāppiyam poems funded by Leppai Nayin̄ār mention his maternal descent from Șadaqatullāh before his paternal descent from Māmu Nayināar, suggesting the repute of his Sufi grandfather. ${ }^{51}$

As Sufi networks, with their claims to distinctive practices and prestigious lineages, encountered each other they also got into conflicts over ideas, practices, and claims to status and lineage. Indeed, the noteworthiness of the Shādhiliyya in the region has been predicated on precisely the fact that it was able to carve out a niche for itself in a "religious marketplace" monopolized by the authority of the Qādiriyya. Like the latter, the Shādhiliyya-Fāsiyya spread among Muslim "householders," often of elite background, rather than among the itinerant dervish groups where the Rifā'iyya was and remains the dominant Sufi order in the region. These social dynamics provided ample opportunity for conflict between adherents of different Sufi orders.

Internal controversies in Muslim societies of Tamil Nadu and Lañkā generally revolved around the propriety of various practices and claims to authority. ${ }^{52}$ It is thus hardly surprising that not only individual Sufis or lineages came to contest each other's claims, but also the followers of tariqas as a whole. This became acutely visible when the Shädhiliyya began to challenge the authority of Qādirī networks in the second half of the nineteenth century. The letters to the editor of Muslim Nêcan quoted at the beginning of this chapter are a good example of such exchanges. Concomitantly, the number of letter writers who identified as either Qādirī or Shādhilī Muslims similarly rose. ${ }^{53}$ Although little can be said about the exact dynamics of these controversies, it seems that the complaints tended to be leveled in the first place by the Qādirīs against the Shādhilīs, suggesting that the former may have felt threatened by the expansion of the new order. The most important preceptors and scholars of the two orders seem to have maintained cordial relationships. Thus, the Shādhilī scholar Nūh b. 'Abd al-Qādir wrote Arabic poetry in praise of both al-Fāsī and the Qādirī Mappiḷai Leppai, and a kāppiyam poem composed about the life of al-Shādhilī in 1914 acknowledged the seniority of the Qādiriyya in the region by praising the local Qādirī lineage extending from Bukhārī Tañnal via Shaykh 'Umar to the latter's son and grandson, Kāyalpatṭiṇam Taykā Ṣāḥib and Muhammad Ṣāliḥ, before praising al-Fās̄̄, Shams al-Dīn al-Makkī, and Abū Bakr Miskīn. ${ }^{54}$ 
Nevertheless, their followers appear to have not infrequently viewed each other with suspicion. Particularly irksome for the Qādirīs seems to have been the claim frequently made in Shādhilī writings that the Shādhiliyya was preferable to other tarīqas.

The second part of Muhammad Ismā'īl's collection of hagiographies, tellingly, more or less began with a chapter on the preeminence of the Shādhiliyya (Fậl al-țarīqa al-shādhiliyya). ${ }^{55}$ The most coherent and (for the Qādirīs) annoying exposition of this topic was a tract penned by al-Fāsī himself, titled "The Lordly Introduction Concerning the Preferability of the Shādhilī Țarīqa" (al-Futuhāat al-rabbaniyya fī taf̣̂̄l țarīqa al-shādhiliyya), which enumerated twenty-six reasons why the Shādhiliyya was preferable to all other Sufi orders. It is hardly surprising that the Qādirīs sought to counter this tract and ultimately published a rejoinder to it. ${ }^{56}$ It also seems noteworthy that these controversies between the two orders appear to have been more pronounced in Lank $\bar{a}$, where, in the decades around the turn of the nineteenth century, Muslim elites were beginning to formulate and contest political claims both among one another and with Tamil and Sinhala politicians. In this context, the two predominant orders (at least in the politically dominant southwestern parts of the islands) came to be linked up with rival political factions. ${ }^{57}$

There is, however, far less evidence for the role of tariqas in local religious controversies before the nineteenth century. This is not particularly surprising given that, before the advent of print, such controversies were most likely local and left no trace in the written record. Nevertheless, two factors need to be mentioned. The first has to do with the language adopted as the Qādiriyya's dominant idiom of expression, namely poetry in the style and vocabulary of Śaiva religious poetry in general, and Siddha poetry in particular. Siddha poetry is often considered to have been highly critical of the existing social and religious order. Most scholars have interpreted the Muslim adoption of the Siddha idiom as a sign of accommodation, religious sharing, and an ecumenical commitment to "the brotherhood of a universal faith." 58 Yet this view is one-sided, as it only takes into account the appropriation of Muslim poets by Hindu audiences. Looking at the actual poetry makes it clear that not only did Muslims use standard notions and fundamental texts of Sufi Islam, but they also resignified the vocabulary of Siddha poetry for Muslim use-for example, by taking the term ainteluttu, or "five letters," to refer not to the Śaiva mantra namah śivāya, but rather to the five-letter Arabic term al-hamd. ${ }^{59}$ It may therefore be possible that the adoption of the Siddha idiom served a double purpose, namely, appropriating a popular idiom critiquing Hindu orthodoxy while at the same time subverting that very idiom from a Muslim perspective.

The other noteworthy factor is the peculiar dominance that the Qādiriyya and Rifā'iyya had achieved in the region by the beginning of the nineteenth century. This first raises the question of how far this spread was accomplished at the expense of other lineages, such as the Shatțārī or the Naqshbandī, and how 
far their apparent integration into dominant Qādirī networks was harmonious. It is also surprising that other tarīqas that might have spread in southern India and Lankā have hardly been able to make inroads. Thus, the Chishtiyya with its pan-Indian networks is hardly present in the region beyond the minority Urduspeaking communities. That the Chishtiyya was unable to spread beyond its social base while a tarīqa with no local ties whatsoever like the Shādhiliyya was may hint at what made the latter attractive, namely, its capacity to provide an alternative for Muslim elites (or, perhaps better, "householders") to the predominant Qādirī network(s) while at the same time not being associated with any other established elite social formation in the region, as was clearly the case with the Chishtiyya. The Shādhiliyya was well equipped to offer an alternative to the Qãdiriyya in the region. The network of zäwiyas not only permitted the order to operate independently of religious institutions dominated by Qādirīs, but also provided it with a sacred landscape in a country where the main shrines were associated with combined Qādirī-Rifā' $\overline{1}$ networks. Furthermore, the authority that the Shādhiliyya-Fāsiyya could draw from its association with elites in Mekka, Egypt, and the Ottoman Empire made the order more than capable to take on the established order, much as the connection with the western archipelagos, itinerant tankals, and a cherished but esoteric body of poetry had provided the Qādirī-Rifā' $\overline{1}$ networks with the authority to integrate apparently autonomous Sufi lineages in the preceding centuries.

The discussion presented above has shown that the common assumption of Sufi orders - more specifically, the Qādiriyya — playing a central and more or less unchanging part in Muslim religious life in the Tamil-speaking parts of South India and Lankā for many centuries needs to be questioned and possibly modified. Rather, the data seem to suggest three distinct types of Sufi formations in the region. The earliest recognizable institution is the simple teaching lineage, by which doctrine and practices were passed on through the generations. Although these lineages may ultimately have traced themselves back to a common origin in a particular preceptor, there is relatively little in the material to suggest that. Rather, lineages may actually have been affiliated to different preceptors and the tariqas associated with them simultaneously so that what ultimately came to matter to an individual Sufi in the region in the earlier period was not so much the role as a member of a particular "order" but rather the particularized and localized participation in a teaching lineage through which multiple affiliations could be transmitted. The evidence for these lineages seems to suggest, furthermore, that they mattered only for those Muslims who were actively engaged in the study of religious knowledge, thus necessitating connection with an authoritative teacher for this purpose. There is little evidence of lay (if the term may be used) participation in Sufi practice during this earlier period. Sufism, in other words, seems to have been a part of Islamic learning that mattered to those who possessed or sought that learning, much like law or 
knowledge of the hadīth, whereas ordinary Muslims do not seem to have sought out initiation into any institutionalized Sufi lineage.

This situation seems to have been transformed by new developments starting around 1600. The period that followed saw the expansion of a new type of Sufi network from the western islands via Kerala to Tamil Nadu and Lañkā-a network that was created by itinerant Sufis pledging allegiance to both the Qādiriyya and the Rifā'iyya but that was linked to settled society in the Muslim towns of the region primarily through the Qādiriyya. This network seems not only to have integrated local lineages, but also to have drawn a wider spectrum of local Muslim society into Qādirī devotionalism and commemorative practice, partly by forming an "interpretive community" around the textual corpus of Tamil songs of gnosis. In this network, with its itinerant preceptors, the actual Sufi lineage a person was initiated into seems to have been less important, thanks to its removal from the local scene. What mattered to the initiated layman was not so much the lineage but integration into the network created by these itinerant preceptors. It is only around the end of the eighteenth century that some lineages in this network seem to have risen to prominence and begun to form the nucleus of integrated "lineage orders" of the type that have often been assumed to be representative of Sufi orders. During the nineteenth century, such lineage orders formed the model not only for Qādirī practice, but also for those who challenged Qādirī dominance in the region, most notably the Shādhiliyya-Fāsiyya.

What does that mean for our understanding of Muslim history and the role of "orders" in the region more generally? What social developments were behind the transformations that took place between the sixteenth and nineteenth centuries, and which factors influenced these developments? Much more research is required to address these questions properly, but some observations can be made based on this initial study. Our knowledge of the situation preceding the late sixteenth century is, admittedly, still rather sketchy. However, the extension of a transregional Sufi network that integrated Muslim communities in the region from around 1600 onwards coincides with what appears to be an era of increased competition among religious groups in the region. The inroads made by European powers into both the economic and the religious organization of the central Indian Ocean was only one aspect of these transformations, though one that affected coastal Muslim communities significantly. Another interesting aspect is that the peculiar structure of the network, with its emphasis on the horizontal, integrative aspects of shared texts, interpretive practices, and recollection of a common heritage rather than the vertical hierarchy of the lineage, may have been one way of integrating the dispersed Muslim communities of the region in a situation where no central institution, such as a church or an empire, was able to effect such an integration. Whereas farther to the north Muslim empires may have favored certain Sufi lineages and in the kingdom of Kandy royal patronage supported the spread of the Siyam Nikāya among 
Buddhist institutions, these Sufi networks of the Tamil regions spread without state patronage that could have supported the development of strong vertical integration through teaching lineages, as in the case of the Siyam Nikāya. The Qādirī network of the seventeenth and eighteenth centuries thus thrived not because it "Islamized" the local population but because it provided a means of social and religious integration for dispersed Muslim communities, operating as an integrative force in the absence of a centralizing Muslim state. The combination of strong vertical lineages with the horizontal integration of larger networks was fully achieved only when several developments made such integration feasible in the region. These included a stronger emphasis on the specificity and uniqueness of the lineage not only through common memory, but also through distinctive practices, a common political order that provided a more level playing field for religious groups competing with each other, ${ }^{60}$ and technologies that facilitated the travel of individuals and the reproduction of texts to a far greater extent than had been possible earlier. It thus becomes clear that the history of religious "orders" needs to become far more cognizant of changes in the constitution of such institutions, their interaction, and integration into local society than has so far been achieved by historians of the region.

\section{NOTES}

1. "Katițam,” Muslim Nēcañ 7.15 (12 Āñi 1889): 60.

2. Following Anne M. Blackburn, Buddhist Learning and Textual Practice in EighteenthCentury Lankan Monastic Culture (Princeton and Oxford: Princeton University Press, 2001), p. viii, I have chosen to refer to the island as "Lankā" rather than using the anachronistic name of the postcolonial nation-state "Sri Lanka."

3. "Katițiam," Muslim Necan 7.16 (19 Āñi 1889): 64.

4. The main exception is a massive but unfortunately still unpublished doctoral thesis on the Qādiriyya: Susan Elizabeth Schomburg, “'Reviving Religion’: The Qādirī Sufi Order, Popular Devotion to Sufi Saint Muhyīuddīn 'Abdul Qādir al-Gīlānī, and Processes of 'Islamization' in Tamil Nadu and Sri Lanka" (Ph.D. diss., Harvard University, 2003). See also Frederick de Jong, "Note sur les confréries soufies à Sri Lanka," in Les ordres mystiques dans l'Islam: Cheminements et situation actuelle, edited by Alexandre Popovic and Gilles Veinstein (Paris: Éditions de l'École des hautes études en sciences sociales, 1986), pp. 135137; Muhammad Yousuf Kokan, "Sufi Presence in South India," in Islam in India: Studies and Commentaries, vol. 2: Religion and Religious Education, edited by Christian W. Troll (Delhi: Vikas Publishing House, 1985), pp. 73-85; Dennis B. McGilvray, "Jailani: A Sufi Shrine in Sri Lanka," in Lived Islam in South Asia: Adaptation, Accommodation and Conflict, edited by Imtiaz Ahmad and Helmut Reifeld (Delhi: Social Science Press, 2004), pp. 272-289; Dennis B. McGilvray, Crucible of Conflict: Tamil and Muslim Society on the East Coast of Sri Lanka (Durham and London: Duke University Press, 2008), pp. 292-304.

5. Carl W. Ernst and Bruce B. Lawrence, Sufi Martyrs of Love: The Chishti Order in South Asia and Beyond (New York: Palgrave Macmillan, 2002), p. 11.

6. This is admittedly a tall claim and would need much further investigation. My preliminary assessment stems from the impression that the critique of existing sources developed 
in this chapter can be applied to other South Asian contexts. First, it seems noteworthy how unclear or vague the tarīqa background of many venerated saints and vernacular Sufi poets seems to be. This includes personalities without țarīqa affiliation (e.g., Makhdūm 'Alī of Mahim) or of unknown affiliation (e.g., Shāh 'Abd al-Lațīf of Bhīt). If we add cases where a somewhat obscure lineage seems retrospectively to have been interpreted as a full-fledged țariqa (as in the case of the Maghribiyya in Gujarat) or where a tariqua seems to be ascribed on the basis of an individual's peculiar traits (e.g., itinerant preceptors identified as Madārī or Rifā‘ $\bar{i}$ ), this covers a large number of South Asian Sufis. Second, it is noteworthy how rarely specific orders (in opposition to the basic meaning of țariqa as part of the Sufi "path" in general) are mentioned in precolonial South Asian Islamic literatures apart from Persian. Important Sufi poets rarely mention their țarīqa affiliation, and the most central literary genre for the conceptual articulation of the Sufi order, the hagiography of local saints, seems strangely undeveloped in most vernacular Muslim literatures of South Asia, in striking contrast to both Muslim Persian and non-Muslim vernacular literature in the very same languages! This may suggest that Sufi orders were of greater importance as a discursive concept of Persianate political and historical discourse than as social institutions in South Asia.

7. The centrality of the Muslim state as an organizing trope characterizes otherwise very different works. Cf., for example, Raziuddin Aquil, In the Name of Allah: Understanding Islam and Indian History (Delhi: Penguin Books India, 2009); Jamal Malik, Islam in South Asia: A Short History (Leiden: Brill, 2008); Mohammad Mujeeb, The Indian Muslims (London: Allan and Unwin, 1967); Annemarie Schimmel, Islam in the Indian Subcontinent (Leiden: Brill, 1980).

8. The classic treatment of this trope is Simon Digby, "The Sufi Shaikh as a Source of Authority in Medieval India," Purușārtha 9 (1986): 57-77.

9. The connection between the initiatory "lineage" (silsila) and the "order" (tarīqa) is so close that some authors translate silsila as "order"; see, for example, Aquil, In the Name of Allah, p. 10.

10. Desai mentions a "Mosque of Shaikh Shādhilı̄" in Kozhikode, Kerala, which contains an inscription dating to $1727 / 1728$. I have not been able to find out more about this mosque, whether the mosque already existed by the time the inscription was made, and whether it was already known by that name then; Ziyaud-Din A. Desai, A Topographical List of Arabic, Persian and Urdu Inscriptions of South India (Delhi: Indian Council of Historical Research and Northern Book Centre, 1989), p. 102 (no. 1065).

11. Concerning Abū Bakr Miskīn, see A. S. Satakkattullāh, "Șātuliyyā tarīkkāvinn cañkaimiku kalīpa," in Paijul Añvār Arapik Kallūri velḷi vilāa cirappu malar (Kadayanallur: Paijul Añvār Arapik Kallūri, 2000), p. 242; Tayka Shu'ayb, Arabic, Arwi and Persian in Sarandib and Tamil Nadu: A Study of the Contributions of Sri Lanka and Tamil Nadu to Arabic, Arwi, Persian and Urdu Languages, Literature and Education (Madras: Imāmul 'Arūs Trust, 1993), http://www.maqbara.com/tariqa.php (accessed March 16, 2014). On Lañkā, see https://en.wikipedia.org/wiki/Ummu_Zavaya (accessed August 14, 2016); http://www .fassiyanews.com/fassiyathush-shazuliyya/baithul-fassi/ (accessed August 14, 2016). The latter article was purportedly written by Hatoon Ajwad Al Fassi, a descendant of Muhammad al-Fāsī and currently associate professor of history at King Saud University, Riyadh, Saudi Arabia. De Jong, "Les confréries soufies à Sri Lanka," 135, erroneously claims that Macan Marikkar was the first to introduce the Fāsiyya to Lankā.

12. Regarding the Darqāwiyya and the Fāsiyya, see Thomas Eich, Abū l-Hudā aṣ-Ṣayyādī: Eine Studie zur Instrumentalisierung sufischer Netzwerke und genealogischer Kontroversen im 
spätosmanischen Reich (Berlin: Klaus Schwarz Verlag, 2003), pp. 56-57, 166-168; J. Spencer Trimingham, The Sufi Orders in Islam (New York and Oxford: Oxford University Press, 1998 [first published 1971]), pp. 110-114 (Trimingham calls the Fāsiyya "Raḥmāniyya").

13. Shams al-Dīn al-Makkī apparently also initiated a few North Indian Muslims, as is evinced by a rhymed Persian silsila by one of his disciples published in Moradabad; Hashmat 'Alī Shāh, Silsilat al-dhahabiyya a'nī shajarat al-shādhiliyya (Moradabad: Maṭba' Gulzār Aḥmadī, ca. 1890).

14. Concerning Māppiḷ!ai Leppai and his lineage, see Sayyid Muhammad b. Aḥmad al-Qāhirī al-Kīrkarī, Fat-ḥud-dayyān fi fiqhi khairil adyān (A compendium on Muslim theology and jursiprudence) (Colombo: The Fat-hiud-dayyān Publication Committee, 1963), pp. xviv-xxxvi; Shu'ayb, Arabic, Arwi and Persian, pp. 580-604, 627-640; Torsten Tschacher, "How to Die before Dying: Šarī'a and Sufism in a Nineteenth-Century Tamil Poem," in Islâm: Collected Essays, edited by Daniele Cevenini and Svevo D’Onofrio (Bologna: I libri di Emil, 2010), pp. 434-436.

15. McGilvray, "Jailani."

16. Desai, Topographical List, pp. 93-95 (nos. 977-994); Mehrdad Shokoohy, Muslim Architecture of South India: The Sultanate of Ma'bar and the Traditions of the Maritime Settlers on the Malabar and Coromandel Coasts (Tamil Nadu, Kerala and Goa) (London and New York: Routledge, 2003), pp. 275-289. For Sayyid Muhyī al-Dīn, see Desai, Topographical List, p. 95 (no. 995); note that, although in the latter case ten generations of ancestors are mentioned, only Sayyid Muhyī al-Dīn and his father carried "Qādirī" names but none in the earlier generations; for the contemporary situation in Kayalpattinam, see Schomburg, "Reviving Religion," pp. 193-196.

17. Desai, Topographical List, pp. 95-96 (nos. 1001-1002, from Kilakkarai); p. 115 (nos. 1201-1204, from Madurai); p. 128 (no. 1314, from Periyapattinam); p. 155 (nos. 1576-1579, from Valinokkam). All these inscriptions date to the fourteenth century except for the four inscriptions from Valinokkam, which date to the fifteenth century.

18. Torsten Tschacher, "Convention and Community: The Poetics of Prefaces to Early Islamic Tamil Literature," Zeitschrift für Indologie und Südasienstudien 28 (2011): 191.

19. Muḥammad Ismā‘̄il al-Nākafattan̄̄, Hidāyat al-sālikīn fĩ takhlīs al-hālikīn (Madras: Matba' al-Qādiriyya, AH 1316), pp. 12-23.

20. Torsten Tschacher, "Circulating Islam: Understanding Convergence and Divergence in the Islamic Traditions of Ma"bar and Nusantara," in Islamic Connections: Studies of South and Southeast Asia, edited by R. Michael Feener and Terenjit Sevea (Singapore: Institute of Southeast Asian Studies, 2009), p. 55; cf. Azyumardi Azra, The Origins of Islamic Reformism in Southeast Asia: Networks of Malay-Indonesian and Middle Eastern 'Ulama $\vec{a}$ ' in the Seventeenth and Eighteenth Centuries (Crows Nest: Allen and Unwin; and Honolulu: University of Hawai'i Press, 2004), pp. 16-20; Shu'ayb, Arabic, Arwi and Persian, pp. 496498. The Naqshbandiyya's role in the region has similarly been ignored, though as late as the 1870s there were self-identifying Naqshbandīs among Tamil Sufis; Șākumukammatu Aptulkātiru Jeyinnuttīn, Murītuvilakkamennnum irattinaccurukkam (Singapore: Saȳiti Yēntiracālai, 1878), [preface p. 1]; Sayyid Muḥammad al-Naqshbandī al-Qādirī, Tab'īn alra'y al-qiyāsī min aqwāl Muhammad al-Maghribī al-Fāsī (Madras: Mu'ayyid al-Islām, AH 1327) (the fatwa on which this tract was based was completed in AH 1291 [1874/1875 CE], as can be gleaned from p. 196).

21. Vètapurānam 25.95: nal parakkatt' ākum kātiriyyattaip pițittukkonțāal. Periya Nūku

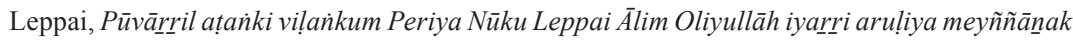


karuvūlam Vēta Purānam, edited by Mu. Ceyyitu Muhammatu "Hasanַ” (Chennai: Mu.Ki.Mu. Muhammatu Hasan, 1999 [first published 1984]). In contrast, the term țariqa is used in this and other texts only as a general technical term for a stage on the Sufi path and the connected practices, not with regard to specific orders; e.g., Vètapurānam 25.103.

22. McGilvray, "Jailani," pp. 276-283; McGilvray, Crucible of Conflict, pp. 297-304.

23. Shaik Abdul Azeez Saheb, "A 'Festival of Flags': Hindu-Muslim Devotion and the Sacralising of Localism at the Shrine of Nagore-e-Sharif in Tamil Nadu," in Embodying Charisma: Modernity, Locality and the Performance of Emotion in Sufi Cults, edited by Pnina Werbner and Helene Basu (London and New York: Routledge, 1998), pp. 63-65; concerning the Malangs, see Ute Falasch, Heiligkeit und Mobilität: Die Madāriyya Sufibruderschaft und ihr Gründer Badī’ al-Dīn Shāh Madār in Indien, 15.-19. Jahrhundert (Münster: Lit Verlag, 2015).

24. British Library MS 26562/2, folio 56v.

25. McGilvray, “Jailani,” pp. 276-280; also McGilvray, Crucible of Conflict, p. 299.

26. The manuscript was purchased at an Islamic bookstall in Nagore in August 2007. It contains 137 folios of texts in Arabic and Tamil, almost throughout in Arabic script. The first 120 folios are carefully written in black and red ink and contain three sets of texts: a couple of Arabic poems (folios $1 \mathrm{v}-31 \mathrm{v}$ ), a Tamil prose version of the Tawaddud story from the Arabian Nights (folios 33r-65r), and the Pismil Kuram, a Tamil "Sufi” poem by Pīr Muhammad of Takkalai. The following folios (122r-126r) are taken up by Arabic poems written in blue ink, the quality of writing indicating that they may have been the writing exercises of a child. The final pages (again in a more mature hand) include a Qādirī silsila (129r-130r), a Tamil text on the Qādirī adab of dhikr (131v-134r), and a single page mentioning the names and dates of birth of three boys born between 1933 and 1952, possibly the sons or grandsons of the woman who owned the manuscript (135v). This is the only page in the manuscript fully in Tamil script. That Balqīs Bī was the owner of the manuscript becomes clear from a marginal note to that effect in Tamil script on folio $5 \mathrm{v}$.

27. Nile Green, Sufism: A Global History (Chichester and Malden: Wiley-Blackwell, 2012), p. 82.

28. Indira Peterson, "Tamil Śaiva Hagiography: The Narrative of the Holy Servants (of Śiva) and the Hagiographical Project in Tamil Śaivism," in According to Tradition: Hagiographical Writing in India, edited by Winand M. Callewaert and Rupert Snell (Wiesbaden: Harrassowitz Verlag, 1994), pp. 191-228; a somewhat similar case, with a late development of hagiographies of Muslim saints despite the existence of non-Muslim hagiographies and Muslim narrative literature about the prophets, seems to be provided by Bengali; Hans Harder, Sufism and Saint Veneration in Contemporary Bangladesh: The Maijbhandaris of Chittagong (London and New York: Routledge, 2011), pp. 106-112.

29. The inclusion of al-Shādhilī at such an early date (ca. 1700) is surprising; Rasūl mālai 76-77, 79, 89, 93 (in Muḥammad Yūsuf Labbay, ed., Ușūl al-asnā fì ḥuṣūl al-ḥusnā [Madras: Maṭba‘ Shāh al-Ḥamīdiyya, AH 1352], part 1, pp. 194-195).

30. For the two most important poems, Sām Shihāb al-Dīn's Mīrān (or Mīrā) mālai and Javātuppulavar's Muhiyittināṇțakai Piḷlaitamill, see Muhammad Yūsuf Labbay, Ușūl al-asnā, part 1, pp. 223-232; and Ku. Jamāl Muhammatu, Collampu: Makān Javātuppulavar (Erode: Ku. Jamāl Muhammatu, 1999), pp. 59-113.

31. Regarding these poems and their literary context, see Tschacher, "Convention and Community"; Mahmood Mohamed Uwise, Muslim Contribution to Tamil Literature (Madras: Fifth International Islamic Tamil Literary Conference, 1990 [first published 1953]). 
32. Muḥammad Ismā‘̄îl, Hidāyat al-sālikīn; Nūḥ b. 'Abd al-Qādir al-Qāhirī, Nafahāat al'anbar fī manāqib al-quṭb al-akbar (Bombay: al-Mațba' al-Gulzār Ḥasan̄̄, AH 1320). Shu'ayb, Arabic, Arwi and Persian, pp. 274-289, 492-493, gives conflicting information on Nūh's lifetime; I have given the most likely dates. For early printed hagiographies, see J. B. Prashant More, Muslim Identity, Print Culture and the Dravidian Factor in Tamil Nadu (Hyderabad: Orient Longman, 2004), pp. 203-228.

33. More, Muslim Identity, p. 209; Mukammatu Mukiyittīñleppai Hāji Pulavar, Cātuli nāyakam, 2nd edition (Jaffna: Mukammatu Mukiyittīn Hāji Pulavar, 1964 [first published 1914]).

34. The copy in my possession consists of three separate parts that may have been printed separately and only bound together later by a reader; the titles of the three parts are Mawlid ' $a t \bar{a}$ ' al-rasūl fī mahtid sakhā' al-batūl, Hidāyat al-rabb al-matīn fì manāqib al-shaykh mu'ìn al-dīn, and Manā'ih al-qudsiyya fì siyar khulafä' al-chishtiyya. Khwāja Muhammad al-Kanjiwī, ed., Mawlid 'ațā' al-rasūl fī mahtid sakhā' al-batūl (Madras: Maṭba' al-Raḥmān̄i, AH 1333).

35. My understanding of "interpretive communities" is based on Blackburn's use of the term in her study on eighteenth-century Lankan monasticism; Blackburn, Buddhist Learning, pp. 89-90.

36. For Qādirī debates, see, for example, "Kațița tārpariya vițai," Muslim Nēcan 7.22 (31 Āṭi 1889): 86; "Cañkaiporuntiya muslim nēca pattirātipa ravarkaḷuk [sic] calām,” Muslim Nēcan 7.26 (28 Āvaṇi 1889): 103-104; “Cammāñkōtțu ālimukku,” Muslim Nēcan 7.27 (4 Purațtāai 1889): 107. For catalogs of Sufi orders, see Muhammad Ismā'̄il, Hidāyat al-Sālikīn, pp. 266273. Regarding the link between print and the production of hagiographies, see Nile Green, Bombay Islam: The Religious Economy of the West Indian Ocean, 1840-1915 (Cambridge, UK: Cambridge University Press, 2011), pp. 92-104. On the use of print by Sufis in Southern Asia in general, see Green, Bombay Islam, chaps. 3 and 6; Michael Laffan, The Makings of Indonesian Islam: Orientalism and the Narration of a Sufi Past (Princeton: Princeton University Press, 2011), pp. 60-62, 143, 154.

37. Green, Sufism, p. 84.

38. Jamil M. Abun-Nasr, Muslim Communities of Grace: The Sufi Brotherhoods in Islamic Religious Life (New York: Columbia University Press, 2007), chaps. 5-7. At the same time, there has also been the opposite process of the transmission of Shādhilī texts outside Shādhilī institutions and contexts, such as the cases of al-Bușīrī's Burda and Ibn 'Ațā’ Allāh's Hikam (personal communication by R. Michael Feener, Oxford, January 2016).

39. Leiden University Manuscript OR-7368, folio 5v; also Ph. S. van Ronkel, "A Tamil Malay Manuscript," Journal of the Straits Branch of the Royal Asiatic Society 85 (1922): 29-35. Most noteworthy, especially in a tract written by a student of Shaykh Șadaqatullāh, is the use of texts by al-Burhānpūrī and al-Qūshāshī, authors highly popular in Shațtāiñ networks.

40. See Abdul Majeed Mohamed Sahabdeen, The Sufi Doctrine in Tamil Literature (Colombo: Abdul Majeed Mohamed Sahabdeen Trust Foundation, 1995 [first published 1986]); Susan Elizabeth Schomburg, "'Hey, Girl! Dance the Kummi Called "Motcam"!"”: The Sufi Poetics of Iḷaiyānnkuṭi Kaccippillaiyammāl,", in World Without Walls: Being Human, Being Tamil, edited by R. Cheran et al. (Toronto: TSAR Publications, 2011), pp. 86-108; Schomburg, "Reviving Religion," pp. 383-424.

41. “Cammāñkōtțu ālimukku,” Muslim Nēcan 7.27 (4 Purațtāci 1889): 107.

42. See More, Muslim Identity, p. 57.

43. Sayyid Muḥammad b. Aḥmad al-Qāhirī al-Kīrkarī, Fath al-dayyān fī fiqh khayr al-adyān (Bombay: Maṭba' al-Shaykh Hasan b. Bahā’ al-Dīn al-Khatīb al-Kōkan̄̄, AH 1291), 
part 1, p. 46; translated in Sayyid Muhammad b. Aḥmad, Fat-hud-dayyān, p. 74. The respective stanza is from one of Mastān Șāhịib’s kìrttañais, no. 18 (1074.1) in Mā. Vaṭivēlu Mutaliyār, ed., Kuṇañkuṭi Mastān Cākipu pātalkal (uraiyuțañ) (Chennai: Mullai Nilaiyam, 2004), p. 398.

44. For a critique of this assumption, see Torsten Tschacher, "Can 'Om' Be an Islamic Term? Translations, Encounters, and Islamic Discourse in Vernacular South Asia," South Asian History and Culture 5.2 (2014): 199-203.

45. See again Blackburn, Buddhist Learning, for my use of the term "interpretive community."

46. Green, Sufism, p. 82.

47. Torsten Tschacher, “'Walls of Illusion': Information Generation in Colonial Singapore and the Reporting of the Mahdi-Rebellion in Sudan, 1887-1890," in Singapore in Global History, edited by Derek Heng and Syed Muhd Khairudin Aljuneid (Amsterdam: Amsterdam University Press, 2011), pp. 57-78.

48. Nūḥ b. 'Abd al-Qādir, Nafahăt al-'anbar, p. 8. For newspaper items, see, for example, "Cātiliyyā tarīkkattin ceykunāyaka mavarkaḷuṭaiya maraṇam," Muslim Nēcan 7.29 (18 Purațạāci 1889): 116; "Cātuliyyāttarīka," Carvajananēẹan 4.10 (March 23, 1889): 38; "Cātulimavulān̄ā avarkaḷn vapāttu," Carvajananēean 4.30 (September 16, 1889): 118; "Cātiliyyā," Carvajananēecan 4.35 (October 30, 1889): 138.

49. British Library MS 26562/2, folio 53v; the word read as "Sorcery" here might also be "Larceny."

50. Ibid., folio 56v. A beautiful description of the way in which a Maldivian tankal used his claim to be able to work miracles to gain patronage in a village in Kanniyakumari District early in the twentieth century can be found in one of the best-known Muslim novels in Tamil: Thoppil Mohammed Meeran, The Story of a Seaside Village (Hyderabad: Orient Longman, 1998).

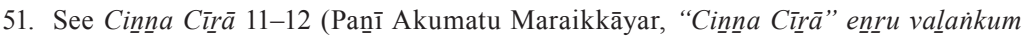
Cīrāp purānam: Hijrattuk kānțtam-2, edited by Em. Saiyitu Muhammatu "Hasañ" [Chennai: Millat Piriṇțars (P. S. M. Ahmatu Aptul Kātir), 1990]); Tirumaṇakkātci 31-32 (Vakutai Cēkāti Nayin̄ārp Pulavar, Tirumanak Käțci, edited by Mu. Ceyyitu Muhammatu "Hasañ" [Chennai: Maraikkāyar Patippakam, 1990]). Regarding Cītakkāti, Māmu Nayinnār, and Leppai Nayin̄ār, see Lennart Bes, "The Setupatis, the Dutch, and Other Bandits in Eighteenth-Century Ramnad (South India)," Journal of the Economic and Social History of the Orient 44.4 (2001): 540574; David Shulman and Sanjay Subrahmanyam, "Prince of Poets and Ports: Cìtakkāti, the Maraikkāyars and Ramnad, ca. 1690-1710," in Islam and Indian Regions, edited by Anna Libera Dallapiccola and Stephanie Zingel-Avé Lallemant (Stuttgart: Franz Steiner Verlag, 1993), vol. 1, pp. 497-535, though these authors seem not to have been aware of the family connections between Leppai Nayin̄ār, Șadaqatullāh, and Cītakkāti.

52. Green, Sufism, p. 175.

53. In addition to the two letters quoted at the beginning, see "Muslim Nēcap pattirātiparavarkalukku," Muslim Nēcan 7.19 (10 Āṭi 1889): 76.

54. Cātulināyakam, Kațavul vālttu 15-20; for the poems authored by Nūḥ, see Muhammad Ismā‘īl, Hidāyat al-sālikīn, p. 219; Shu'ayb, Arabic, Arwi and Persian, p. 629.

55. Muhammad Ismā̄î̀l, Hidāyat al-sālikīn, p. 229. At the same time, this book was printed at a printing press called al-Qādiriyya!

56. Sayyid Muḥammad al-Naqshbandī, Tab'īn al-ra'y al-qiyāsī; an online biography of al-Fāsī, apparently produced by a Syrian lineage gives the title of al-Fāsì's tract as al-Futuhāt al-rabbaniyya wa al-ijāza al-madaniyya, "The Lordly Introductions and the Authorization of 
the Madaniyya," and claims that it contains twenty-five arguments; http://privat.bahnhof.se /wb042294/Texter/bionotes/bio_m_fasi.html\#10 (accessed March 10, 2014).

57. Christian Wagner, Die Muslime Sri Lankas: Eine Volksgruppe im Spannungsfeld des ethnischen Konflikts zwischen Singhalesen und Tamilen (Freiburg i.Br.: Arnold-BergstraesserInstitut, 1990), pp. 83-85. For the general political context, see also M. N. M. Kamil Asad, The Muslims of Sri Lanka under British Rule (Delhi: Navrang, 1993); Wagner, Die Muslime Sri Lankas, pp. 63-98.

58. K. Kailasapathy, "The Writings of the Tamil Siddhas," in The Sants: Studies in a Devotional Tradition of India, edited by Karine Schomer and W. H. McLeod (Delhi: Motilal Banarsidass, 1987), p. 407.

59. E.g., Vètapurānam 25.82 .

60. Green, Bombay Islam, pp. 8-23. 


\title{
WHOSE ORDERS?
}

\author{
Chinese Popular God Temple Networks \\ and the Rise of Chinese Mahāyāna \\ Buddhist Monasteries in Southeast Asia
}

KENNETH DEAN

Anthony Reid has traced the religious revolutions of Southeast Asia during the fifteenth, sixteenth, and seventeenth centuries, as Theravāda Buddhist monastic orders and ritual traditions spread across mainland Southeast Asia and Islam competed with Christianity in the insular regions. ${ }^{1}$ He has also noted the expanding role of Chinese merchants as middlemen in the British and Dutch colonies of Malaya and Indonesia. However, he makes little mention of the role of Chinese temples or of the spread of Chinese Mahāyāna Buddhism to Southeast Asia - although French travelers had already reported the presence of Chinese Buddhist monks in the Qingyunting (Pavilion of the Blue Clouds) in Malacca in $1698 .^{2}$

The lack of a Chinese cultural context elsewhere in Southeast Asia would make the spread of Chinese Mahāyāna challenging and complex. Although the evidence on the spread of Mahāyāna Buddhism to Southeast Asia is sparse for the early modern era, we can trace the rise of full-fledged Mahāyāna monasteries and religious orders in the late nineteenth century. Reid briefly discusses the spread of Confucian culture and Chinese Mahāyāna within Vietnam, where a shared Chinese language and cultural context facilitated the spread of Buddhist orders. ${ }^{3}$ At that time Chinese religious networks also expanded in the region through connections with traditions of Daoist ritual masters. Evidence for this includes a wooden "earth contract" from 1898 that was discovered during renovations to the Po Chiak Keng Tan Si Chong Su in Singapore. This ritual artifact demonstrates that Daoist ritual specialists conducted rites to exorcise the space of the temple and consecrate the new gods upon their installation and animation in diaspora Chinese contexts of the region. ${ }^{4}$

When scholars of religion speak of the spread of religious orders in Southeast Asia, however, they usually refer to the expansion of Theravāda 
Buddhist monastic lineages, Islamic prophetic lineages (often related to Sufi teachers), or later lineages of Christian missionaries associated with Catholic monastic communities. What is strangely overlooked in these accounts is the long historical development of a vast network of Chinese temples in Southeast Asia dedicated to the gods of the regional pantheons of the different emigrant communities.

This chapter explores the expansion of a Chinese temple network that began in Fujian in the sixteenth century, spread across Southeast Asia in the seventeenth and eighteenth centuries, and accelerated its spread in the nineteenth century with the arrival of immigrants from multiple dialect regions. For centuries, Chinese temples and their native-place business offices provided the main institutional framework for the elaboration of trust networks holding long-distance trade together across the "Minnan coastal trading system." These temples held rituals before the gods in which the two sides of a trading contract would swear to maintain their trust. Such rites (and institutions) were especially important because these were "merchants without empires," side the legal protection of the Chinese state in treacherous environments. The temple business offices lent out funds and supervised credit pools watched over by the gods, which were designed to cover the costs of key life-cycle rituals for the members of the pool. Funds could be withdrawn for weddings, "cappings" (of young men come of age), or funerals and then returned with interest for the next person who needed them. The temple officers registered the marriages and deaths in their dialect communities, fulfilling ritual as well as bureaucratic roles. These temples were staffed by miaozhu (temple invokers), who were responsible for tending the incense and oil lamps, and assisting worshipers in making prayers and offerings. They were directed by temple management committees made up of Chinese leaders who held high positions in local society as wealthy merchants and traders. Because ritual roles were "differentially distributed" across Chinese society, these temple managers along with leaders of guilds, opera troupe directors, carpenters, and heads of households were all able to perform specific ritual roles. ${ }^{7}$ Thus, larger rituals in temples could be conducted by the temple leadership, with one or more being selected annually to fill the ritual role of keeper of the incense burner, while other leaders in the community were assigned ritual roles as "leading families." Members of the temple committee could also serve as temporary masters of ritual ceremony (lisheng) during rites held in temples and ancestral halls.

These temples were transnational religious institutions linked by the division of incense marking generations of affiliations (see below). They were characterized by possession rituals that authorized expansion of the networks in new directions. Thus, although not defined by specific institutionalized lineages descending from a particular teacher or monastic adept, Chinese temples can be seen as transregional institutionally based religious orders in a broadly comparative sense. They are also transpersonal in the sense that different individuals 
rotated in and out of ritual roles and that spirit mediums were possessed by "outside" supernatural forces. The Chinese temples of Southeast Asia also invited in or temporarily housed representatives of more formal religious orders (defined by participation in specific lineages of monastics or masters) such as itinerant Buddhist monks and Daoist ritual specialists. Such itinerants performed rites of consecration of temples, animation of god statues, feasts for the gods or the ancestors, or funerals for individual members of the dialect communities. They also sometimes took care of the temple or the burial grounds of a particular dialect group. As will be seen below in the case of the Shuanglinsi (Double Grove Monastery) in Singapore, such itinerant monks were in some cases taking part in extended pilgrimages to Buddhist centers in Sri Lanka. These pilgrimages were an extension of the common process of yunyou (moving like a cloud), in which monks traveled from one monastery to another within China in search of an inspiring master and possibly a better position within a monastic organization. As for Daoist ritual specialists, many who are currently active in Southeast Asia are the descendants of men who emigrated for a wide range of reasons and who often worked in additional trades, only occasionally serving as Daoist ritual masters.

The Chinese temples of Southeast Asia are dedicated to a mixture of regional deities, mostly of Daoist derivation, as well as Buddhist gods such as Guanyin. ${ }^{8}$ The diverse regional Daoist ritual traditions of Fujian coevolved along with the many regional pantheons of the dialect groups who founded these temples. Each dialect region along the coast of China (or inland in the case of Hakka regions) had its own topolect, distinctive temple architecture, regional pantheon, regional ritual traditions, food, clothing, and regional local customs. Each regional Daoist ritual tradition formed its own distinct lineage of groups of masters (and is thus referred to as a "formal religious order" above), although these were primarily transmitted through initiation rituals along paternal lines or between masters and disciples.

The Tianshifu (Celestial Master Headquarters) at Longhushan (Dragon Tiger Mountain) in northern Jiangxi was, at various times, a center for the coordination of regional Daoist ritual traditions and for the conferral of additional ordinations to the regional ritual specialists. However, integration across the wide range of distinct regional ritual traditions was minimal. For the most part, these localized Daoist orders were based in the homes of the Daoist masters and usually not in temples. ${ }^{9}$ The regionally based Daoist ritual specialists did, however, contribute to the process of transforming many local god cults into regional, national, or transnational cult networks by writing up the invocations, legends, and miracles of the gods and then composing scriptures and liturgies for some of them, thus inscribing them within a shared "universal" Daoist liturgical framework. For centuries, starting with the large-scale migration of Han Chinese into Southeast China in the Tang, Five Dynasties, and Song eras, leaders of the local communal temples in different parts of Southeast China 
hired Daoist ritual masters to perform communal offerings (jiao) dedicated to the local gods on their feast days. Local communal temples were important centers of village life, forming the core of local self-governance of territorial communities. ${ }^{10}$

By the seventeenth century at the latest, branch temples from founding temples of the main gods of Fujian had spread to many parts of Southeast Asia. It is likely, however, that there were smaller shrines and temples in Chinese communities in Southeast Asia much earlier. Admiral Zheng He (1371-1433), for example, found over three thousand Chinese living in Palembang (Sumatra) in the early fifteenth century. ${ }^{11}$ Most branch temples were established by means of a ritual of "division of incense" from the founding temple, and some have divided incense with newer third- or fourth-generation temples elsewhere in Southeast Asia, generating a network of affiliation, or a lineage. Often, small statues of the gods of the founding temples were carried overseas by emigrants (fenling, or division of the god's spiritual power). Some branch temples maintained strong ties with their founding temples in Southeast China.

Spirit mediums, a regular feature of the Southeast Chinese religious world, could become possessed by the gods of the regional pantheons back in China. These gods might insist (through the spirit medium) that their devotees build a temple to the deity in a new land in Southeast Asia. Spirit mediums flourished in these temples, perhaps because the Southeast Asian contexts lacked key features of the southern Chinese ritual sphere that restricted the space available to spirit mediums there, such as tightly interlocking strata of Confucian literati, localized lineages, strong traditions of Daoist ritual masters or Buddhist monasteries, and a hierarchy of local temples intersecting with the state cult at City God temples.

Of the many elements of the various regional ritual spheres of Southeast China that could be found in the Chinese temples of Southeast Asia, including temple managers acting in a ritual capacity, hired temple invokers, spirit mediums attached to a temple, itinerant Buddhist monks, and Daoist ritual specialists, only the latter two could be considered to be members of formal religious orders, and those of the regional Daoist ritual masters were often particularistic and fragmented. Nevertheless, careful procedures for the rotation and selection of temple management committees and annual keepers of the incense burners as well as the continuous production of spirit mediums ensured continuity of ritual practices within temple communities over hundreds of years. Even when formal religious orders were not present, we can identify what I refer to as "networked orders," shaped through the transpersonal transmission of ritualized roles within nodes of translocal networks rather than by individuals taking up vocations within a dedicated lineage in a stably institutionalized context. ${ }^{12}$ This chapter presents a history of the rise and intensifying presence of formal religious orders in the Chinese religious context of Southeast Asia, a process linked 
to changes in temple environments, social functions of temple spaces, and the forms of social authority linked to Chinese temples. These changes occurred over several centuries. This chapter will trace particular strands of developments in the area that later became the British Straits Settlements.

I examine Chinese temple networks from a historical perspective, tracing the growth of the network of Hokkien (Fujian Minnan-speaking immigrants) temples from the seventeenth through the eighteenth centuries, followed by the rise of Teochew, Hakka, Cantonese, Hainan, and other regionally based and dialect-specific temple networks in the nineteenth century. Powerful emigrant communities from these different regions of Southeast China controlled the branch temples as well as the huiguan (native-place associations or business offices) housed within the temples. These temples/huiguan provided rooms for visiting Chinese business travelers from their regions of origin, loaned money to those linked to their associations, and managed graveyards for those unable to return to their points of origin.

The temples/huiguan were also at the center of intense and sometimes violent conflict between dialect groups (and among their business leaders) over control of the opium, alcohol, and prostitution farms (cartels, or monopoly rights) auctioned off by the colonial administration, which provided over half of the annual income of the Straits Settlement colonies. ${ }^{13}$ The cartel business leaders were often the leaders of the temples/huiguan. They needed to have a strong enforcement apparatus to handle conflicts; administer monopoly control over the distribution of opium, alcohol, and prostitutes; and control the coolie trade within the mines and plantations across Southeast Asia. Many of the latter were owned and managed by the same Chinese leaders who served as managers of temples/huiguan within their dialect communities (which had specific residential zones, commercial territories, and economic niches). The sworn brotherhoods responsible for the enforcement of the cartels were often linked to the temples. These groups would later be stigmatized (and eventually criminalized) by the colonial authorities as Triads or secret societies. ${ }^{14}$

In the second half of the nineteenth century, there was a fundamental transformation in the structure and relative autonomy of temples/huiguan as Western colonial authorities made a deliberate attempt to separate these temples from their enforcement arms (secret societies/Triads). This was a long process, which took place in different colonial settings across Southeast Asia over the second half of the nineteenth century. Bureaucratic solutions and evolving imperial knowledge/power formations developed across the reach of the British Empire in Asia, through the itineraries of various colonial bureaucrats, officials, and governors, who experimented with different but converging policies over time across the empire to deal with the problem of the Chinese communities (that is to say, the temples/huiguan) and their secret societies. In different port cities at different times for different reasons, after gradually criminalizing 
the enforcement arm of the Chinese temples/huiguan, the colonial powers proceeded to regulate the finances and eventually the administrative structures and operations of the temple organizations - and this tended to continue into the postcolonial period. Leaders of the Chinese community realized that the ground rules had shifted and opted to focus more of their energies on emerging Chinese chambers of commerce. In some cases, they chose to cede control over some temples to more formal religious orders and to sponsor the establishment of local Buddhist monasteries. It is in this context that, at the end of the nineteenth century, we find evidence for the establishment of the first mainstream Buddhist monastery in Malaya, the Jilesi (Monastery of Extreme Joy) in Penang in 1905, followed by the founding of the Shuanglinsi (Double Grove Monastery) in Singapore in 1909. ${ }^{15}$

\section{THE DEVELOPMENT OF THE OVERSEAS CHINESE TEMPLE NETWORK}

In order to get a sense of longer-term Buddhist connections between Southeast Asia and China, one can turn to earlier travel accounts of monks, historical records, and stone inscriptions. Tansen Sen has discussed the flow of monks back and forth from India to China from the Han to the Tang/Song period. ${ }^{16}$ Claudine Salmon has discussed religious exchanges between the Buddhist kingdom of Srivijaya (based in contemporary Palembang and Jambi in Sumatra) and Song China. The next period of intense contact between Chinese Buddhists and Southeast Asia began at the end of the Ming era and continued through the beginning of the Qing. During the Qing Manchu takeover of China, the entire coast of Southeast and South China endured a coastal evacuation policy, which lasted for up to twenty years (1660-1680) in some regions. Tens of thousands of villages were abandoned and destroyed along with many thousands of temples dedicated to popular gods and Buddhist monasteries. These measures were intended to eliminate any sources of support for the armies and navies of the Ming resistance, including those of Zheng Chenggong (1624-1662) and his son Zheng Jing (1642-1681) on Jinmen and later on Taiwan, and those of the Ming armies in the southwest. These policies drove many coastal residents to emigrate to Southeast Asia.

In the 1990s, Zheng Zhenman and I gathered inscriptions in temples and monasteries in the Quanzhou and Zhangzhou regions of Fujian. ${ }^{17}$ We located an inscription dated 1697 at the Dragon Pool Buddhist monastery in Haicang, which revealed that this monastery had sent out Buddhist monks to Southeast Asia to raise funds for the reconstruction of the temple immediately after the Qing coastal evacuations. Leaders of the Chinese community in Batavia responded to their call and donated substantial sums toward the reconstruction of the temple. The Baosheng Dadi (Great Emperor Who Protects Life, a deified doctor from the Song named Wu Tao [979-1036]) temple nearby in Qingjiao, 
Haicang, which dates back to the Song dynasty, also preserves a stele from the Kangxi period (also dated 1697) titled Baguo yuanzhu beiji (Stele record of the patrons from Batavia), describing how many of the same Chinese leaders in Batavia recorded on the Dragon Pool Monastery inscriptions agreed to donate two years of the income of their branch temple (presumably dedicated to Baosheng Dadi) to help pay for repairs to the temple. ${ }^{18}$ Many other temples along the coast aimed to do the same. ${ }^{19}$

The Qingyunting (Pavilion of the Blue Clouds) in Malacca was one of the most important Chinese temples in Southeast Asia. This temple (not a monastery) was founded around 1673 by Ming loyalists including Zeng Qilu (16431718) and Lin Weijing (1614-1688). ${ }^{20}$ Currently, the temple is dedicated to both Tian Hou (the Empress of Heaven, also known as Mazu, Goddess of the Sea) and Guanyin (the Mahāyāna Buddhist Bodhisattva of Mercy). The temple played a key role as the political command center for the Chinese community, with the pavilion director usually also serving as the Kapitan of the Chinese (appointed by the Dutch and later the English to administer the Chinese community). The temple also played a key role as a business center and social club for wealthy merchants who made up the temple management committee. They lent temple funds to smaller merchants and entrepreneurial immigrants, and maintained control over credit-pooling associations (for life-cycle ritual needs) housed inside the temple.

Reading through the epigraphy of this temple, we find early inscriptions praising the founders of the temple, Ming loyalist refugees from the Manchu takeover of China. ${ }^{21}$ Some of the leaders inscribed steles at the Baoshanting (Precious Mountain Pavilion), a temple built at the foot of Sanbaoshan, the main Chinese cemetery in Malacca, which was sponsored and managed by the Qingyunting. Later inscriptions at the Qingyunting celebrate the success of the local merchant class. Other inscriptions continue to highlight the role of the leading Chinese merchant families of the region, with some early founders visited in dreams in order to display their virtuous natures.

From an early period, the Qingyunting temple hired Buddhist monks to conduct ritual services. One of the first accounts of the Pavilion of the Blue Clouds was provided in 1698 by the French voyager François Froger. ${ }^{22} \mathrm{He}$ describes visiting the temple and observing men in robes chanting over tables covered with offerings. Although he could not understand a word they said, he was certain that they were religious specialists (presumably Buddhist monks). He knew it was a temple because of the three icons on the altar. He also made a sketch of the temple, revealing that at that time it had only a single room, with statues of (Buddhist) deities on the altar at the back of the hall. The Qingyunting leaders also sponsored Buddhist rites at the nearby cemetery hill. The following inscription at the Precious Mountain Pavilion at the foot of the Hokkien cemetery hill was written by Cai Shizhang, who served as pavilion director of the Qingyunting, in 1801: 
The Precious Mountain Pavilion is a place where the secluded deceased are offered sacrifices with respect. ... It is decided that of the entire year's rent from the property, 25 wen should be given to the monk[s] of this pavilion as "incense salary," 20 wen should be given to the master of the incense burner of that year so that he can separately set up offerings before the [main] spirit tablet[s] on days on which families make sacrifices. The remainder left over should be held on to and saved for use on future repairs. ${ }^{23}$

This passage reveals that, in the early period, the Buddhist monks connected to the Baoshanting Precious Mountain Pavilion were on a small salary from the Qingyunting. Similar indications can be found in inscriptions at several temples and cemetery shrines in Singapore. ${ }^{24}$

By the late eighteenth century, a shift occurs in the inscriptional record of the Qingyunting. We find a broader merchant class represented in steles and wooden plaques dedicated to Mazu or to Guanyin. In the nineteenth century, the temple was expanded, and new halls were added dedicated to the worship of the unrequited dead, with inscriptions outlining the development of a Pudu (Hungry Ghosts Universal Deliverance) Association. Here we see a shift from serving the top leadership or the merchant elite to a concern for the local Chinese community as a whole and their many deceased ancestors. This shift also implies the need for a broader range of ritual observances on the part of resident Buddhist monks.

\section{THE MAIN EARLY TEMPLES OF THE SINGAPORE DIALECT COMMUNITIES}

The earliest Hokkien temples and cemetery shrines in Singapore were built by leaders of the Qingyunting in Malacca, including Director of the Pavilion Si Hoo Keh (Xue Foji, 1793-1874), who helped sponsor the construction of the Tianfugong on Telok Ayer Street in Singapore in 1840. Si had first served as director of the Hokkien cemetery in Singapore, the Hengshanting (Pavilion of the Everlasting Mountain), founded in 1828. His sons succeeded him in this role, even after he returned to Malacca to take up the post of pavilion director once again. Several other Malacca peranakan (Southeast Asian-born Chinese) businessmen from Malacca banded together to build the Chongde (Worshiping Virtue) pagoda next door to the Tianfugong, and their descendants still worship their forefathers there on a triannual basis.

The formation of the old town of Singapore, at the mouth of the Singapore River, saw the rise of distinct dialect territories in which people from the same region in South or Southeast China gathered and built their temples, nativeplace and clan associations, as well as their shops that monopolized different 
trades and commercial activities. The boundaries of these dialect neighborhoods were preserved from the founding of Singapore in 1819 until the beginning of the urban development of Singapore island in the mid-1950s. Currently, only traces of these communities can be seen in the few temples left behind. The dialect communities have now been dispersed across the entire island into the HDB (Housing and Development Board) blocks built by the government in the satellite towns around Singapore island.

Each dialect group contains many subsections, based on combined principles of a common place of origin and dialect (as these can differ considerably by region within the broader dialect area). Often, within the same dialect and territorial subgroup, there are also divisions based on common surname, class, education, and gender. Thus, for example, the immigrants to Singapore from Jinmen divided into two groups, with the merchant leaders worshiping Chen Yuan (fl. 804), a Tang dynasty military founder of Chinese communities on the islands, and the lower-class dock workers who lived in coolie houses worshiping Liu Wangye (sometimes called a "plaque demon"), who is said to have been an officer under Chen Yuan in the Tang.

Stone inscriptions from the Heng San Ting (Eternal Mountain Pavilion) (built in 1828, burned down in 1997) and the Kim Lam (Golden Lotus) temple in Singapore provide some insight into the status of the monks attached to the major temples of the Chinese merchant communities in the period preceding the rise of organized monastic Buddhism and the later spread of Reform Buddhism. ${ }^{25}$ In the Five Regulations Agreed Upon though Discussion at the Eternal Mountain Pavilion, dated 1836, we find the following:

Third regulation: As for the splendid Mid-Autumn Festival, the funds raised by the Master of the Incense Burners and the Heads of the Families for ritual sacrifices and offerings can all be kept as blessed objects in the homes of the Master of the Incense Burner. When he wishes to invite all the Heads of the Families to partake in the blessed offerings, of whatever funds were raised, if there is any remainder, it should be given to the monks to cover the expenses of tobacco, old leaf [betel nut], and tea, and to cover the costs of his annual ritual expenses and of any occasional costs for the entertainment of visitors. Whomever takes turns and posts a proclamation for the two ceremonies of Qingming, and the monks should take care of and attend to. ... If there are those who do not follow this regulation, they will receive ritual punishment or be sent away. Everyone must obey the public agreement, there being no exceptions for individual feelings.

This passage clearly indicates that the monks are receiving leftover funds from ritual offerings and that they are expected to be continuously on call and ready to provide ritual services to whomever asks to perform rites at the pavilion. 
Fourth regulation: On the festivals of Qingming, the seventh month Pudu, and the Mid-Autumn Festival, it is decided that extraneous idle people will not be allowed to set up gambling tables inside and outside of the Pavilion, as this would bring disruption to the order of the [Pavilion]. If there are any who disobey, we will invite the police to come and take them away to be punished by the Chief of Police. We also will not allow any Buddhist monk within the Pavilion to sell opium or to set up an opium den within or nearby the Pavilion. If there be anyone who disobeys and does not respect [this regulation], and who is then discovered by the people, then this monk will be expelled, and the opium den will be dismantled. There will be no mercy.

From the point of view of the temple leadership, the morals of the itinerant monks were suspicious. They were apparently thought likely to be involved in opium and gambling.

Fifth regulation: As for the funds for incense [operational expenses] of the Mt. Heng Pavilion, each first and fifteenth day of the lunar month, the Buddhist monks should go down into Singapore to gather contributions. As for the Chinese, Thai, Vietnamese, or other foreign sailing boats or double decked boats that have safely reached Singapore each year, it is publicly agreed that each Chinese boat that belongs to someone from Quanzhou or Zhangzhou [prefectures] will make a contribution of four Spanish [(Lu)song, Manila Spanish] silver dollars. The sojourners on board these boats can make any [additional] contribution their hearts desire. As for Thai, Vietnamese, or other foreign sailing boats or double decked boats, and every other kind of boat, regardless of the size of the boat, so long as the boat belongs to a person from Quanzhou or Zhangzhou, it has been publicly decided that each boat will contribute two Spanish silver dollars. Should it happen that, during the annual contribution, a Singaporean boat has a captain [or owner] who refuses to obey, then if the captain or anyone else registered to his crew should happen to pass away, by public decision they will not be allowed to be buried in this cemetery. The Buddhist monks of this Pavilion should refuse them. If anyone from Quanzhou or Zhangzhou prefecture passes away and wishes to be buried in this cemetery, he or she must obtain a permit from the Master of the Incense of that year, which must be handed over to the monks of the Pavilion as evidence. Anyone who has not received a permit as proof should be refused by the monks.

As can be seen from the inscription above, the Buddhist monks working at the Chinese cemetery shrines were a floating population very much at the service 
of the temple leadership in contrast with later scenarios in which temples developed around monastics stably resident in a monastery linked to the Buddhist temple.

Another inscription from the Golden Orchid Temple sets out regulations concerning itinerant Buddhist monks and Daoist ritual masters and shows that the day-to-day activities of the temples were carried out by ritual specialists (temple keepers, or invocators, who would assist worshipers with their prayers and offerings, and tend to the incense and oil lamps in the temple). Monks and Daoist masters were not lodged permanently in these temples. The Regulations of the Golden Orchid Temple, dating to 1891, reveals that the itinerant Buddhist monks and Daoist ritual masters were under suspicion from the leadership for their tendency to make money on the side with gambling tables and the sale of opium. They were called on to provide ritual services at the temples on a regular basis and at the cemeteries during Qingming (sweeping of the graves) and Zhongyuan Pudu (universal deliverance of the hungry ghosts in the Middle Prime [lunar 7/15]), but they were expected to subsist on the leftovers from the sacrificial offerings. Other inscriptions from this period describe the (quite low) wages provided to monks, many of whom seem to have been largely peripatetic.

This was not the only scenario for monks' involvement with temples in nineteenth-century Singapore, as some temples contained monastic residents and granted monks more status. Some temples in Fujian dedicated to local gods maintained historical connections with Buddhist orders. This was also the case for the Hong San See (Fengshansi, lit., Phoenix Mountain Monastery), which was dedicated to Guangze Zunwang, the Reverent King of Broad Compassion (Guo Mingliang, 899-922). The mother temple of this god, one of the greatest of the Fujian local god cults, is located in Shishan township in upper Nanan County. ${ }^{26}$ For centuries, the cult center has been maintained by Buddhist monks, although the god is best known for his highly Confucian filial piety, manifested in his visits to his parents' tombs (to apologize for becoming a Daoist immortal before they had died). The historical links with Buddhism at this temple center ensured that Buddhist monks were invited to its branch Fengshansi temple in Singapore (built in 1836), housed at the temple, and put in charge of the upkeep of the temple of the god's cult after it was moved to Mohammed Sultan Street. This progression can be seen from the epigraphy in the temple. The names of other Buddhist monks are also inscribed on steles revealing their roles in the running of the Linshanting Beijigong (Temple of the Northern Polestar of Unicorn Mountain Pavilion, built before 1866), another temple in charge of yet another Hokkien cemetery in Singapore. The Tianfugong, the main temple of the Hokkien community on Telok Ayer Street, also housed Buddhist monks at various times (such as Master Hong Choon, who resided there for several years in the 1930s). Nonetheless, it is important to note that even in these instances characterized by resident monks being offered greater status, these were all 
temporary institutional arrangements rather than permanent multigenerational monasteries. They thus left little scope for the training of future generations of monks.

\section{JILESI IN PENANG AND THE TRANSFORMATION FROM SALARIED EMPLOYEES TO BUDDHIST ENTREPRENEURS}

A major turning point in the rise of Chinese Mahāyāna monastic orders in Southeast Asia in the nineteenth century was the founding of the renowned Jilesi (Monastery of Extreme Joy) in Penang in 1898. The monastery was founded by the monk Miaolian (1824-1907), who had been sent in 1888 to Penang by the Gushan Yongquansi outside Fuzhou to raise money to repair his home temple. Miaolian set in motion a major transformation of local roles for Buddhist monks in the region. Miaolian worked with the local Penang Chinese temple leadership to develop a new system of financing for temples, with novel roles for the monks within the temple. The system changed the position of a Chinese Buddhist monk in Southeast Asia from a salaried itinerant to participant in a contract system wherein monks would handle all the finances of the temple, with any additional profits in temple income beyond the initial annual rental fee becoming their own. ${ }^{27}$ Miaolian used these additional profits to begin the process of constructing a Mahāyāna monastery in Penang.

Before Miaolian's arrival, one finds scattered earlier records of Buddhist monks working in Penang on inscriptions within the Guangfu (Guangdong and Fujian) Temple, which had been founded in 1800. The 1824 Chongjian Guangfu gong beiji (Stele record of the reconstruction of the Guangfu Temple) states, "After we rebuilt the inner courtyard and buildings, and set up the images of the saints therein, then to the side we built quarters for monks to live in and made them complete." ${ }^{28}$ However, within three decades a new monastic lineage began to take shape in Penang. The 1923 Gazetteer of the Penang Crane Mountain Jile Monastery, written by (Wei) Baozi, states,

Formerly, in the dinghai year of the Qing [1888], Chan Master Miaolian came once more to Penang. The elite [merchants] Qiu Tiande, Hu Taixing, Lin Huacan, Tiao Xingyang, and so forth, invited him to become the abbot of the Guangfu Temple and charged him over 2,000 in gold for the annual rental [of the temple]. The name of this practice is called baojuma [contracting for annual temple income]. From this time on, the monks of the Gushan Monastery [near Fuzhou] became the leaders of the Guangfu Temple.

Although Miaolian left the Guangfu Temple within three years, he arranged for a series of his disciples to come from his Fuzhou home monastery, Gushan Yongquansi, to succeed him as abbots for over twenty-five years. Miaolian then began the process of establishing the Jilesi in a quiet spot outside of the crowded 
city center with support from local Chinese business leaders and eventually from the dowager empress of China.

Financial matters within the Guangfu Temple led to a government audit. ${ }^{29}$ The entrance on the scene of a group of monks held together by strict master-disciple relations, having a specific code of conduct (internal regulations), and with an institutional base in an ancient, established Chan monastery back in Fujian (the Yongquansi is a renowned thousand-year-old Buddhist monastery outside Fuzhou City founded in 908) introduced a different set of relations between abbots and monks, on one hand, and between the monks and temple sponsors and everyday worshipers, on the other hand. Moreover, it reshaped relations between the temples (or monasteries) and the colonial authorities. These new monastic arrangements with the first establishment of a formal Buddhist order in Penang thus altered the religious ecology of the region.

An inscription written by Miaolian for the Jilesi dated 1907 outlines twenty-one detailed regulations for the conduct of the monks in the monastery. ${ }^{30} \mathrm{He}$ includes detailed rules on lines of authority (the abbot in the founding monastery in Fujian held decision-making power and exclusive rights to ordination of new monks), accounting procedures, and issuing of wages, and limitations on the hosting of "floating cloud" itinerant monks, who were restricted to a maximum stay of only one week. There were also warnings about not falling under the sway of local patrons and preserving Buddhist control over the monastery.

The Jilesi attracted considerable support and local funding from several of the wealthiest Hakka businessmen in Penang and across Southeast Asia. Five of them served as successive managing directors. These were (1) Zhang Bishi (cognomon Zhenxun, 1840-1916), a Hakka entrepreneur from Dapu, appointed Chinese consul in Penang and later consul general in Singapore; (2) Zhang Yunan (cognomon Rongxuan, fl. 1891-1912), from Meixian, who owned rubber plantations, was appointed Kapitan of Deli in Sumatra by the Dutch, and was named Chinese consul to Penang by the Qing imperial court; (3) Xie Rongguang (1846-1916) from Meixian, Kapitan under the Dutch and a consul in Penang, who served for over a decade as managing director of the temple; (4) Zheng Siwen, a mining magnate from Zengcheng County in Guangdong, who was made a Kapitan in Perak; and (5) Dai Chunru (d. 1919) from Dapu, another extremely wealthy managing director, renowned for his philanthropy, who established hospitals and schools, and contributed greatly to the monastery. Some of these patrons were major investors in the coastal railroad to Shantou in China. Other prominent patrons who merited special biographical notices in the Gazetteer include Zhang Hongnan (d. 1921), brother of Zhang Yunan, who also made his fortune in rubber plantations and was appointed major in Deli by the Dutch colonial government (he was a close friend of Buddhist monk Benzhong). Finally, Madame Lin, née Chen Xinan, made generous donations to the monastery, which were recorded in multilingual inscriptions. 
An inscription dated 1906 reveals the vast transnational network of sponsors supporting this temple, who altogether contributed the sum of 210,030 yuan to the monastery. Sponsors include the businessmen listed above as well as individuals and native-place associations from all over Malaya, Singapore, and Indonesia, as well as patrons in Fujian and Jiangxi in China. ${ }^{31}$ In response to this outpouring of support, a final unique set of plaques and inscriptions, including one by the dowager empress Cixi, details the transmission of a complete set of the Buddhist Canon (Tripitaka) from the Imperial Household via the (Folusi) Buddhist Registry Office to the Jilesi Monastery in Penang in 1904. This was the first Tripitaka to be sent to Malaysia, and the inscriptions (including one that was the inscribed record of a telegram from Beijing) make clear that these scriptures were intended for a foreign Southeast Asian audience. ${ }^{32}$

\section{THE LIANSHAN SHUANGLINSI AND THE RISE OF BUDDHIST MONASTICISM IN SINGAPORE}

The story of the founding of the first mainstream Buddhist monastery in Singapore revolves around a family of roaming Buddhist monks and nuns. However, in this case, they were Chinese Buddhist pilgrims who had traveled for several years in Sri Lanka and who were persuaded to stay in Singapore, where they stopped on their return trip to China. Low Kim Pong (Liu Jinbang, 1837-1909) donated land and set out to build a monastery (and a nunnery) for them. The mother of the founding monk wrote the following personal account of the tribulations of her family. Unfortunately, the original stele has been lost, but the text was preserved:

I am from Huian county in Quanzhou prefecture [in Fujian, China]. My lay name is Xiao. My entire family united together and sought after the delights of Buddhism. As a result, my two sons became enlightened and floated through life as though it was a dream. They urged us to search out the truths of Buddhism, so in the renchen year [1892] I followed along with the entire family of men and women, twelve in all. We sailed by boat to Colombo and spent six years in the mountains in Sri Lanka. When it reached the $w u x u$ [1898] year, in the spring we came down from the mountains and traveled all over the Buddhist kingdom. Later, we traveled to Penang and passed by Singapore, planning to return to our home country. We were greeted by the Patron Low, who graciously offered to donate this mountain [property to serve as a monastery]. Therefore, my eldest son, Xian Hui, built the Double Grove Chan Monastery here. He also planned to build a Zhulin [Pearl Gem] Nunnery behind the main hall of the monastery to provide a place for myself, my eldest daughter, Chan Hui, who was also nun, and my niece, Yueguang, who is also nun, so that all three of us could stay together. Unexpectedly, my son Xian Hui suddenly cast away his 
body of illusory transformations in the summer of the xinqiu year [1901] and entered into the realm of Nirvana. But at this time the construction was not complete, and life seemed to float like a dream: isn't that just the way things are! But since we, mother and son, had already been here for several years, I had a great desire to see the great work completed. Then above we could repay the Buddha's mercy. But now that things have come to this, what am I to say? Now my [second] son, Xing Hui, has already returned to the True, and it is no longer convenient for us three women to remain here. Therefore, I intend to give instructions that my second son Xing Hui's disciple, Great Master Mingguang, should manage what still needs to be done. Only by working hard will he be able to carry on the aspirations of his predecessors. [That he will] not let down the ancestral ways is what I earnest hope for. Now we will take the next boat back to our country, and I cannot help but feel emotional. So I have specially composed these few words and engraved then on fine stone, so that those of you who come passing by will know the origins [of this monastery] and also know that the Pearl Gem Nunnery is the Dharma hall, and the Dharma hall is the nunnery. On an auspicious day in the autumn of Guangxu renyin [1902], erected by Nun Cimiao. ${ }^{33}$

This touching and very personal inscription reveals that the founding monks of Lianshan Shuanglinsi (Lotus Mountain Double Grove Monastery) were itinerant monastics returning to China from a pilgrimage to Sri Lanka when they encountered the lay Buddhist patron Low Kim Pong. The decision to construct a full-fledged Buddhist monastery in Singapore at this point reflects a desire on the part of leading members of the lay Buddhist Singapore elite to localize Chan Buddhist orders from their founding monasteries in Fujian to Southeast Asia. Other mobile Buddhist monks also took advantage of changing circumstances, including changes in colonial policies toward religious institutions and the Chinese temple network, to set up smaller-scale temples in Singapore. ${ }^{34}$

\section{THE COLONIAL REGULATION OF RELIGION}

Looking back over developments within the Chinese religious sphere in Malaya and Singapore in the nineteenth century, one can see that colonial regulation of Chinese religion from the mid-1850s led to a gradual dismantling of central elements of the Chinese temple system, which combined communal leadership and enforcement in the form of secret societies. These colonial policies resulted in the creation of a new, autonomous category of "religion," as well as the separation among Chinese between a privatized sphere of religion and a public life based ultimately in chambers of commerce. Related colonial policies included the gradual elimination of Chinese cemeteries, the removal of hawkers from 
the five-foot ways, and other efforts to improve hygiene and regulate colonial space. ${ }^{35}$ These transformations were facilitated by the rise of English-educated Chinese in mission schools, British universities, and government service. The rise of Chinese modern nation-state nationalism during the Republican period intensified the rejection of the earlier Chinese temple system among educated elite Chinese leaders. ${ }^{36}$

It is useful to analyze the impact of colonial conceptions and regulations of religion on the subsequent transformation of the Chinese dialect community temples. These policies were worked out across the British colonies, from colonial statements in India on religious tolerance, to bans in Madras on Thaipusam processions, to clashes in Penang, Hong Kong, and Singapore with secret societies. The colonial knowledge machine was creating and imposing categories as fast as it was absorbing and attempting to assess and categorize perceived new threats (such as the potential for the Kongsi in Borneo to become independent). The following regulations and policy changes enacted across the Straits Settlements had a major impact on Chinese temple networks in Malaya and Singapore as well as in Hong Kong:

\section{6: Penang riot over an opera stage}

1867: Penang riot featuring feuding "secret societies"

1867: Peace Preservation Act: giving British authorities the right to banish undesirable individuals

1869: Dangerous Societies Suppression Ordinance: calling for the registration of all "secret societies" but only laxly enforced

1877: William Pickering appointed to the Chinese Protectorate in Singapore: working closely with the so-called secret societies, he argued for coordination with the colonial authorities

1887: Assassination attempt on Pickering

1890: Societies Ordinance Act: declaring sworn brotherhoods completely illegal and criminalizing such groups

1891: New prisons built in Singapore

1899: Chinese Advisory Board established: encouraging greater cooperation with the colonial authorities

1905: Mohammedan and Hindu Endowment Board established to coordinate these religious institutions with colonial authorities

1906: Singapore Chinese Chamber of Commerce established

With the prohibition of secret societies in 1890 (which took place later in Singapore than in Penang and Hong Kong), the enforcement arm of the temple 
and clan association business leadership was criminalized. At the same time, British authorities were intruding more and more into the financial side of temple administration. An example of this was noted earlier, in relation to the Guangfu Temple in Penang. An audit in 1890 led to the enforced reorganization of the temple's administrative structure and financial accounting procedures. This audit likely shaped the decision of temple leaders to transfer control over temple finances to the Buddhist monk Miaolian and his Chinese monastic order.

\section{LAST STAND OF THE NINETEENTH-CENTURY CHINESE TEMPLE SYSTEM}

Cheang Hong Lim (Zhang Fanglin, 1842-1892) was one of the preeminent leaders of the Singaporean Chinese community at the end of the nineteenth century. His engagement with the Chinese temple system represents a last effort to hold together the pieces of this rapidly changing system. Cheang was a major partner in the Great Opium Syndicate of 1890s Singapore, a position he inherited from his father, Cheang Sam Teo. ${ }^{37}$ The vast fortune accumulated by controlling opium sales enabled Cheang to invest in property, diversifying his holdings. Over time, he built or restored six Chinese temples. Cheang first restored the temple established by his father dedicated to an obscure local god from his home region in Fujian called Qingzhen Yuanjun (Primordial Lord of Pure Perfection). He also built a temple at his seaside villa to house a boulder worshiped as an Earth God by local people. Later he restored the Golden Orchid Temple, which was a center of the secret societies of the Hokkien faction. In this context, he attempted to establish rules for this temple to enable its selfregulation, trying to keep a step ahead of colonial regulations forbidding secret societies. He also built a temple to the Jade Emperor, which attempted to transcend dialect boundaries and create the basis for new forms of Chinese leadership and alliances within Singapore. Bound closely to the Qing court and involved in disaster relief programs in Asia and beyond, Cheang received titles and honors from the Chinese imperial court as well as recognition and honors from the colonial authorities and other Asian governments. Most important here is Cheang's role as leader of the Chinese community in Singapore. According to his epitaph, he was regarded as the "chief libationer"- the head ritual specialist — of the entire Chinese community of Singapore. Cheang's activities as a patron of many Chinese temples and societies operated according to the earlier logic of Chinese temple administration marked by nonmonastic control and tight interconnections between ritual and commercial activities. At his death, Cheang was recognized in these terms by many associates and clients, yet this occurred as the Chinese temple system was undergoing massive transformations that eventually led to privileged Buddhist monastic leadership rather than that of nonmonastic entrepreneurs. 


\section{THE RISE OF MODERN(IST) TEMPLE LEADERS AND REFORMIST BUDDHIST MONKS}

Despite the efforts of figures like Cheang Hong Lim, leadership based in the temples and associations would soon give way to modern forms of nationalism and capitalist networks. More and more, the Chinese leadership in Singapore was drawn into the process of building a Chinese modern nation-state. These leaders turned their energies away from the Chinese temple network that Cheang had worked so hard to preserve. Instead, they were content to allow Buddhist monks to run increasing numbers of monasteries.

Tan Kah Kee (Chen Jiageng, 1874-1961), leader of the Hokkien Huay Guan (native-place association) and founder of the Ee Ho Hean Club, was dedicated to supporting the revolutionary cause in China. He is an example of the new kind of leader who helped to develop newly emerging organizational forms. He raised large sums to support China in the first half of the twentieth century, founding modern educational centers such as Jimei College and Xiamen University. Other Singaporean Chinese leaders of the first half of the twentieth century, such as Lim Boon Keng (1869-1957), were closer to colonial rule, through English schooling in the missionary schools, scholarships to study in England, and government employment and honors. Later in his life, Lim turned to a reformed Confucianism as an alternative to Christianity as well as to Chinese popular religion. Negative attitudes toward Chinese popular religious practices - involving the temple network discussed at length above - can be seen in his editorials published in the leading Singaporean Chinese newspapers at the turn of the century. ${ }^{38}$

Such attacks led Singaporean Chinese Buddhist leaders to participate in reform movements designed to rationalize Buddhism and make it more compatible with the modern nation-state and its secular modernization projects (including its new definition of religion). ${ }^{39}$ Taixu (1890-1947) and other Buddhist reform leaders came to Singapore in the Republican period to attempt to counter Japanese propaganda on the unity of the Asian races, the rise of the Pan-Asian Co-Prosperity Sphere, and the role of (Japanese state-linked) Buddhism within this vision. ${ }^{40}$ These Chinese Reform Buddhism leaders also had a major impact on local Buddhist organizations within Singapore. They worked with Buddhist monks trained in China (primarily in the Fujian Chan Buddhist monasteries of Quanzhou, Xiamen, and Zhangzhou) to turn the major Buddhist centers in Singapore into centers of modern Reform Buddhism. ${ }^{41}$ Reform Buddhism's emphasis on spirituality over ritual and on the cultivation of the self paralleled the emphasis of the Protestant missionaries, who established several mission schools in this period still considered top elite schools in Singapore. One can see these developments as instances of a "conversion to modernity." 42

However, the rise of Reform Buddhism was not the only development in Buddhist circles in Singapore and Southeast Asia. Several other more traditional 
Buddhist monastic networks had begun to extend into Southeast Asia in the Republican era and up to the early 1950s. One such network linked a series of temples across Southeast Asia to the Guanghuasi (Monastery of Broad Transformations, founded in $558 \mathrm{CE}$ ) in Putian. As soon as it was possible to return to China in the early 1980s, monks from this network (including those from the Singapore Guanghuasi) returned with suitcases full of cash to rebuild the Guanghuasi, which had been turned into a plastics factory and where several monks had committed suicide after refusing to eat meat and return to a secular life at the height of the Cultural Revolution. ${ }^{43}$ Yet another such mainstream or unreformed Buddhist monastic network extends from the Guishansi (Turtle Mountain Monastery) in Huating, Putian, to the Qingyunting in Malacca, and from there to Muar, Penang, Singapore, Jakarta, and elsewhere. This network was able to mobilize related networks of Putian immigrants (spirit mediums, native-place associations, Mazu temples of fishermen/smugglers) to rebuild the founding temple and to use remaining funds to rebuild the home village in Huating of the Buddhist abbot Zhen Jing and to build an even larger temple across the street from the Qingyunting in Malacca. ${ }^{44}$

In the last Singapore census, conducted in 2010, over one million Singaporeans identified themselves as Buddhists. ${ }^{45}$ Given the growing predominance of "socially engaged" or "human realm" Buddhist transnational organizations, such as the Ciji (Merciful Salvation) Foundation, Fagushan (Dharma Drum Mountain), and Foguangshan (Buddha's Light Mountain International Association) based in Taiwan, the history of twentieth-century Chinese Mahāyāna Buddhism is being rewritten as the inevitable triumph of Reform Buddhism. ${ }^{46}$ This narrative leaves out many alternative lineages and developments in the region. Multiple networks link Buddhist monasteries and Chinese temples to their founding sacred sites in South and Southeast China. They provided another key vector for the spread of variant forms of Mahāyāna Buddhism into Southeast Asia within networks of sectarian lay-Buddhist movements. ${ }^{47}$ Several of these networks maintain important but little studied traditions of Buddhist practice. For instance, lay-Buddhist groups in Southeast Asia such as the Xiantian Dao (Way of Prior Heaven) studied by Marjorie Topley set up zhaijiao (vegetarian retreat) centers for women. There are currently some thirty temples in Singapore linked to the Xiantian Dao, now under the leadership of the Kwan Im Thong on Waterloo Road. ${ }^{48}$ These "vegetarian associations" were places of refuge for many Cantonese female laborers, spinsters, and orphans who moved to or were born in Singapore in the second half of the nineteenth century. This organization is now one of the wealthiest charities in Singapore.

Another important but more fragmentary network is made up of small nunneries spread across Southeast Asia, which often take in abandoned girls and perform a range of traditional Buddhist practices (reciting scriptures and making offerings to the spirit tablets of the deceased-often a female sponsor of the nunnery). This kind of quasi-private nunnery is also widespread in 
Southeast China. A third lay-Buddhist Mahāyāna network is the Chaozhou Shantang (Halls of Merit) dedicated to the worship of the Song Buddhist monk Song Dafeng (1039?-1127?). This network of halls is of interest because most of the ritual activity is performed by the members themselves, without the intercession of Buddhist monks. The members of the temple don special robes and engage in group recitation. Many halls have set up gongdetang (halls of merit to worship ancestral tablets) as these tablets are being concentrated in such spaces. Halls of merit have evolved into charities that support medical clinics and other contemporary social needs. They constitute a tight, transnational business network. ${ }^{49}$ These groups and others like them far outnumber the established Buddhist monastic orders or the new Reform Buddhist organizations, and they deserve further study. In such groups, we find that the relationship between Buddhist religious orders and their lay followers is blurred, inviting comparison to Chinese temple networks before their restructuring in the late nineteenth and early twentieth centuries under British colonial rule.

This chapter has examined transformations in the nature of the Chinese temple network of Southeast Asia from its early founding in the sixteenth century to its expansion in the seventeenth century after the Qing conquest of China and the consolidation of its central role in Chinese overseas life and transnational trust and trade networks in the eighteenth century. The nineteenth century witnessed exponential growth of the network with the sudden influx of laborers and the concomitant proliferation of temples and associations for dialect groups. For several centuries, Chinese temples and native-place business offices provided the main institutional framework for the elaboration of trust networks that facilitated long-distance trade across the Minnan coastal trading system. I have argued that such Chinese temples in Southeast Asia can be considered informal, transpersonal, translocal, networked religious orders, owing to their ties to founding temples in distinct regions of Southeast China and their provision of ritual frameworks for Chinese communities in Southeast Asia. I have also shown how they incorporated within their ritual frameworks representatives of more formal religious orders, such as itinerant Buddhists or Daoist ritual masters, for specialized ritual purposes. Finally, I have traced the rise of independent Chinese Mahāyāna Chan Buddhist monasteries in the Straits Settlements during the late nineteenth century that were linked to ancient founding monasteries in China by formal Buddhist orders of the time. This innovative moment in the Chinese religious life of the Straits Settlements was dependent on changes in colonial policy toward religion and, thus, on the effects that various projects of secularization had on Chinese societies in Southeast Asia.

In the second half of the nineteenth century, colonial authorities began to regulate and redefine Chinese religious institutions by criminalizing their violent enforcement arms and by forcing greater transparency, or at least accountability, in their management and fiscal accounting. These pressures along with 
the rise of modern nation-state nationalism and the spread of mixed forms of capitalism in the early twentieth century led many Chinese community leaders to channel their energies more into the emerging Chinese chambers of commerce than into existing temple networks.

We have seen how one Chinese leader in mid-nineteenth-century Singapore, Cheang Hong Lim, struggled to hold together the Chinese temple network framework, while many forces were working to undermine its central role in Chinese life. His life marked the end of an era. By the end of the nineteenth century, mobile Chinese Buddhist monks, moving through Southeast Asia on pilgrimage or in search of support for their home monasteries, took advantage of the opening created by the withdrawal of the Chinese leadership and the redefinition of the Chinese temples by the colonial authorities. Working with local business leaders but offering a complete system of temple management, they raised support for the construction of imposing monasteries. The turn of the twentieth century saw the collapse of the Qing dynasty and the rise of Chinese nationalism in Southeast Asia at precisely the moment that Chinese Mahāyāna monasteries were first established in Penang and Singapore.

These Buddhist monastic networks themselves became a site of contestation lasting into the middle of the twentieth century, as institutional debates led by Reform Buddhists like Taixu in China (in response to the widespread assault on popular religion) led to changes in the operations of Buddhist monasteries in Singapore and Malaya as well. As we have seen, the rise of formal monastic orders in Singapore and Malaya/Malaysia during the late nineteenth and twentieth centuries did not lead to a homogenization of Buddhist practice in the region. Many alternative forms of Buddhism, some syncretic and redemptive, others more traditional, continued to develop in Southeast Asia during the twentieth century. The larger Chinese temple network has persisted across time despite substantial changes in leadership and financing that occurred during the period considered here.

In recent decades, many temple communities in Southeast Asia have returned to China, helping to rebuild their founding temples. Hundreds of thousands of temples, monasteries, and ancestral halls have been rebuilt over the past three decades. A great deal of ritual knowledge had been preserved in the Chinese temples of Southeast Asia over the course of the Cultural Revolution, when many ritual traditions, temples, and religious practices were banned in China, in some areas for over two decades if not longer. Thus, the Southeast Asian Chinese temples (along with Taiwanese temples) played a crucial role in reviving, reinventing, and in some cases transforming ritual traditions in Southeast China, including rebuilding temple structures and ancestral halls, a cultural historical phenomenon largely overlooked. In this process, we can trace the role of a complex, historically evolved, transnational network of branch temples, native-place associations, ancestral halls, common surname associations, and Buddhist monasteries and lay movements scattered across Southeast 
Asia. As these temple networks evolve and generate new possibilities, they will continue to draw in and circulate more flows of people, ritual knowledge, and capital, and develop new potentials for the expression of new identities and new aspirations within simultaneously transnational and localized circuits.

\section{NOTES}

1. For more on the spread of Theravāda Buddhism, see Stanley Tambiah, World Conqueror and World Renouncer: A Study of Buddhism and Polity in Thailand against a Historical Background (Cambridge, UK: Cambridge University Press, 1976); Richard Gombrich, Theravāda Buddhism: A Social History from Ancient Benares to Modern Colombo (London: Routledge and Kegan Paul, 1988); Donald Swearer, The Buddhist World of Southeast Asia (Albany: SUNY Press, 2011); Anne M. Blackburn, Locations of Buddhism: Colonialism and Modernity in Sri Lanka (Chicago: University of Chicago Press, 2010).

2. Anthony Reid, Southeast Asia in the Age of Commerce 1450-1680, vol. 2: Expansion and Crisis (New Haven: Yale University Press, 1993).

3. For further discussion of seventeenth-century Chinese Mahāyāna Chan missionary activity linking South China to Vietnam, see Claudine Salmon, "Réfugiés Ming dans les Mers du sud vus à travers diverses inscriptions (ca. 1650-ca. 1730)," Bulletin de l'École française d'Extrême-Orient 90-91 (2003): 177-227; Charles Wheeler, "Missionary Buddhism in a Post-Ancient World: Monks, Merchants, and Colonial Expansion in Seventeenth Century Cochinchina (Vietnam)," in Secondary Cities and Urban Networking in the Indian Ocean Realm, c. 1400-1800, edited by Kenneth Hall (Plymouth: Lexington Books, 2008), pp. $205-$ 230; Charles Wheeler, "Buddhism in the Re-ordering of an Early Modern World: Chinese Missions to Cochinchina in the Seventeenth Century," Journal of Global History 3 (2007): 303-324; Charles Wheeler, "Re-thinking the Sea in Vietnamese History: Littoral Society in the Integration of Thuan-Quang, Seventeenth-Eighteenth Centuries," Journal of Southeast Asian Studies 37.1 (2006): 123-153; Charles Wheeler, "A Maritime Logic to Vietnamese History? Hoi An's Trading World, c. 1550-1830," in Seascapes, Littoral Cultures and TransOceanic Exchanges, conference proceedings (Washington, DC: Library of Congress-The History Cooperative, 2003); Thich Thien-An, Buddhism and Zen in Vietnam in Relation to the Development of Buddhism in Asia (Rutland, VT: Charles Tuttle, 1975).

4. See Kenneth Dean and Hue Guan Thye, Chinese Epigraphy in Singapore: 1819-1911 (Singapore: NUS Press, 2016).

5. The concept of "trust networks" is drawn from the works of Charles Tilly, e.g., Trust and Rule (Cambridge: Cambridge University Press, 2005). See also Kenneth Dean, "Ritual Revolutions," Encounters: An International Journal for the Study of Culture and Society 4 (2011): 17-42.

6. Wang Gungwu, "Merchants without Empires: The Hokkien Sojourning Communities," in The Rise of Merchant Empires: Long-Distance Trade in the Early Modern World, edited by James Tracy (Cambridge, UK: Cambridge University Press, 1990), pp. $400-422$.

7. "Before the nineteenth century ... religious knowledge and authority were differentially distributed, not only among several institutions and categories of clerics, but also among the laypersons who controlled most temples, forming highly complex social fields that did not include an autonomous space designated as 'religion." "Vincent Goossaert and 
David Palmer, The Religious Question in Modern China (Chicago: University of Chicago Press, 2011), p. 10.

8. Chinese popular religion (or local communal religion) blends Confucian morality with the worship of multiple deities, many with a Daoist derivation. Buddhist deities, especially Guanyin and the Goddess of Mercy, were often worshiped within these temples as well. For an account of the social organization and roles of the Three Teachings (Confucianism, Daoism, and Buddhism) within Chinese popular religion, see Goossaert and Palmer, Religious Question, pp. 22-23.

9. The home altars of the Zhengyi (Orthodox Unity) order of Daoist ritual masters contrast with the monastic orders of the Quanzhen (Complete Perfection) tradition. The latter tradition did not move to Southeast Asia until recent decades. Qing dynasty standard Chinese literary sources do not show a clear understanding of the technical terms relating to specific Daoist or Buddhist orders. See Vincent Goossaert, The Taoists of Peking, 1800-1949: A Social History of Urban Clerics (Cambridge: Harvard University Asia Center, 2007). These issues were of importance only within Daoist and Buddhist circles, however.

10. Kenneth Dean, Taoist Rituals and Popular Cults of Southeast China (Princeton: Princeton University Press, 1993).

11. Wang, Merchants without Empires.

12. This raises the important question of the position of the Chinese lineage within Southeast Asian Chinese society. Given the presence of dialect communities from many different regions of the southern and southeastern coast of China, there is no single common regional culture to provide integrated cultural unity in Singapore or elsewhere in the Straits Settlements. Whereas in the regional cultures of Fujian or Guangdong, powerful localized lineages linked up with prominent Daoist ritual masters and Buddhist monks to constrain new local forms of religious authority (such as locally based spirit mediums), this is not the case in Singapore and much of Southeast Asia, where spirit mediums have much more room to maneuver. In the classic model of the Chinese family lineage, in theory, the most important ritual role is assigned to the eldest son of the first line of descent (zhangzi). Such a role is a ritual function passed down within a lineage hierarchy. However, in practice, such rules of ritual priority were often bent or ignored, especially in Southeast Asia, where lineage forms were much more flexible than in South China. See P. Steven Sangren, "Traditional Chinese Corporations: Beyond Kinship," Journal of Asian Studies 43.3 (1984): 391-415. Some immigrant lineages mutated into temple communities, and others developed networks by combining into common surname groups and inventing a common ancestor. Rukang Tien, The Chinese of Sarawak: A Study of Social Structure (London: London School of Economics and Political Science, 1953).

13. Carl Trocki, Opium and Empire: Chinese Society in Colonial Singapore, 1800-1910 (Ithaca: Cornell University Press, 1990).

14. The key Western sources on secret societies and Triads have been republished in a five-volume set. See Kingsley Bolton and Christopher Hutton, eds., Triad Societies: Western Accounts of the History, Sociology and Linguistics of Chinese Secret Societies, 5 vols. (London and New York: Routledge, 2002). For evolving academic views on the role of the secret societies, see Ching-hwang Yen, A Social History of the Chinese in Singapore and Malaya, 18001911 (Singapore: Oxford University Press, 1986); David Ownby and Mary Somer Heidhues, eds., "Secret Societies" Reconsidered: Perspectives on the Social History of Modern South China and Southeast Asia (New York: M. E. Sharpe, 1993); David Ownby, Brotherhoods and Secret Societies in Early and Ming-Qing China (Stanford: Stanford University Press, 1996); 
Jean DeBernardi, Rites of Belonging: Memory, Modernity and Identity in a Malaysian Chinese Community (Stanford: Stanford University Press, 2004). These groups practice elaborate initiations with complex ritual symbolism. While ter Haar demonstrates the continuities between the Triad "demonological" ritual paradigms and broader Chinese religious cosmology, Ownby places "brotherhoods" into the broader context of Chinese social institutions as self-help organizations for marginalized groups of young men. Barend ter Haar, Ritual and Mythology of the Chinese Triads: Creating an Identity (Leiden: Brill. 1998).

15. For compilations of Chinese epigraphic materials, see Ts'ung-i Jao, "Chronological Study of Some Chinese Tablet Inscriptions in Malaysia and Singapore" (in Chinese), Shumu jikan 5.12 (1970): 3-33; Chingho Chen and Tan Yoek Seong, Xinjiapo huawen beiming jilu (A collection of the Chinese inscriptions in Singapore) (Hong Kong: Chinese University Press, 1970); Wolfgang Franke and Ch'en Tieh-fan, eds., Chinese Epigraphic Materials in Malaysia, 3 vols. (Kuala Lumpur: University of Malaysia Press, 1980-1985); Wolfgang Franke, with the collaboration of Claudine Salmon and Anthony Siu and with the assistance of Hu Juyun and Teo Lee Kheng, Chinese Epigraphic Materials in Indonesia, 3 vols. (Singapore: Nanyang xuehui, 1988-1997); Wolfgang Franke, ed., Taiguo Huawen mingke huibian (Chinese epigraphic materials in Thailand) (Taipei: Xinwen fengchu bangongsi, Minguo 87 [1998]); Kenneth Dean and Zheng Zhenman, Ritual Alliances, 2 vols. (Leiden: E. J. Brill, 2010); Kenneth Dean and Zheng Zhenman, Epigraphical Materials on the History of Religion in Fujian: The Quanzhou Region, 3 vols. (Fuzhou: Fujian Peoples Publishing House, 2003); Kenneth Dean and Zheng Zhenman, Epigraphical Materials on the History of Religion in Fujian, vol. 1: The Xinghua Region (Fuzhou: Fujian Peoples Publishing House, 1995); Dean and Hue, Chinese Epigraphy in Singapore. For records of eminent Buddhist monks, see Nanyou yunshui qing: Fojiao dade hongfa Xingma jishi 1888-2005 (Record of Chinese Buddhist missionaries to the South [lit., Feelings provoked by clouds and water in the southern journey]: Record of the great deeds of virtue in the spreading of the Dharma to Malaysia and Singapore, 1888-2005) (Penang: Poh Oo Toong Temple, 2010). These and other sources make it possible to trace some of the lines of development of a complex network of heterogeneous Mahāyāna Buddhist traditions, including the rise of twentieth-century Reform Buddhism. The 1923 Gazetteer of the Penang Crane Mountain Jile Monastery (10 juan), compiled by (Wei) Bao Ci, is one of the most complete early sources available for the establishment of the first Mahāyāna Buddhist monastery in Malaya. Chen Zhakang and Monk Baoci, Gazetteer of the Penang Crane Mountain Jile Monastery (Jiangsu: Guangling guji keyinshe, [1923] 1996); see also Baoci, Heshan Jilesi zhi (Gazetteer of the Crane Mountain Monastery of Extreme Joy) (Penang: Jilesi, 1923).

16. Tansen Sen, Buddhism, Diplomacy, and Trade: The Realignment of Sino-Indian Relations, 600-1400 (Honolulu: University of Hawai'i Press, 2003); Tansen Sen, "The Intricacies of Premodern Asian Connections," Journal of Asian Studies, 69.4 (2010): 991-999.

17. These are recorded in Dean and Zheng, Epigraphical Materials.

18. Claudine Salmon, "Cultural Links between Insulindian Chinese and Fujian as Reflected in Two Late 17th-Century Epigraphs," Archipel 73 (2007): 167-194.

19. Salmon, "Réfugiés Ming."

20. Ibid.

21. Franke and Ch'en, Chinese Epigraphic Materials.

22. François Froger, "Relation du premier voyage des Français à la Chine en 1698-1700," manuscript preserved at the Bibliothèque d'Ajuda in Lisbon, with fifteen maps and plans, including one of the layout of the Qingyunting temple. See Salmon, "Réfugiés Ming." 
23. Franke and Ch'en, Chinese Epigraphic Materials, vol. 1., p. 241.

24. More recently, in the mid-twentieth century, a group of Buddhist monks from the Guishansi (Turtle Mountain Monastery) in Huating near Putian, Fujian, established themselves within the Qingyunting. Disciples of the first monks from the Guishansi went on to establish branch temples in Muar, a port town some 100 kilometers to the south. In the 1990s, third-generation monks from this lineage gathered resources from across a wide range of Putian (Henghua) immigrant networks to rebuild the Guishansi in Putian. Additional funds were used to build the Xianglinsi Monastery of the Fragrant Grove across the street from the Qingyunting, and additional leftover funds were used to rebuild the entire home village (Yuantou cun) of the monk in charge of this project, Master Zhenjing. See Dean and Zheng, Ritual Alliances.

25. The texts blocks quoted below have been published in Dean and Hue, Chinese Epigraphy, chaps. 3-4.

26. Kenneth Dean, Lord of the Three in One: The Spread of a Cult in Southeast Asia (Princeton: Princeton University Press, 1998), chap. 4.

27. Wang Tanfa, "Huanchu 'Xiangzi' du zhongsheng: cong wenwu beiming tantuo 18, 19 shiji Maliujia haixia sanchi de Hua seng hudong" (Exchanging "incense salary" for saving souls: A discussion of the activities of Chinese monks in the three Straits Settlements in the eighteenth and nineteenth centuries from stone inscriptions) (online publication, 2004), http://www.xiao-en.org/cultural/magazine.asp?cat=34\&loc=zh\&id=662 (accessed January 21, 2013).

28. Franke and Chen, Chinese Epigraphic Materials, p. 532. J. D. Vaughan visited this temple in 1851 and commented that the monks there were mostly from Fujian, as were those he had seen in Singapore. Their funding mostly consisted of donations, but they could make a dollar by taking part in a funeral. They also received a dollar from every theater company that performed before the temple. Moreover, Vaughan was not impressed by the level of literacy or doctrinal knowledge of the Buddhist monks he encountered. See J. D. Vaughan, The Manners and Customs of the Chinese of the Straits Settlements (Oxford: Oxford University Press, 1977). This is the same temple that sent out the Chan master Kun Shan to Malacca some sixty years earlier, and it later sent Master Fachuan to Singapore, where he played an important role in the founding of the Guangmingshan Monastery. Penang is also the site of the tomb of a monk from Fujian dated to the seventh lunar month of 1854: "Chan Master of Xibin, Sramana Shun Ji of Kaiyuan(si)" (Jao, "Chronological Study").

29. Penang Gazette Strait Chronicle, February 2, 1888.

30. Franke and Ch'en, Chinese Epigraphic Materials, pp. 662-664.

31. Ibid., pp. 652-658.

32. Ibid., pp. 652-658. Miaolian is a controversial figure in the historiography of modern Buddhism. For a detailed account of the transmission of yet another set of the Buddhist Tripitaka by Master Xuyun from 1907 to 1910, starting from Beijing, then to Xiamen, and then by boat to Thailand, Penang, and Rangoon, and finally by land across Burma to a monastery on Jizu Mountain in Yunnan, see Xuyun, Empty Cloud: The Autobiography of the Chinese Zen Master Xu Yun, translated by Charles Luk, revised and edited by Richard Hunn (Shaftesbury: Element Books, 1988), pp. 94-119. Master Xuyun had been ordained by Master Miaolian, and he brought Miaolian's relics back with him to the Jilesi on this trip. For Miaolian's fundraising efforts in Taiwan, see Hsuan-Li Wang, "Gushan: The Formation of a Chan Lineage during the Seventeenth Century and Its Spread to Taiwan" (Ph.D. diss., Columbia University, 2014). 
33. Kenneth Dean and Hue Guan Thye, Chinese Epigraphy of Singapore: 1819-1911, 2 vols. (Singapore: National University Press, 2017), p. 1127.

34. For an account of the regulation of Hindu and Islamic religious institutions under British colonial administrations, see Vineeta Sinha, Religion State Encounters in Hindu Domains: From the Straits Settlements to Singapore (Dordrecht and New York: Springer, 2011). On the establishment of Theravāda religious institutions in Singapore, see Anne M. Blackburn, "Ceylonese Buddhism in Colonial Singapore: New Ritual Spaces and Specialists, 1895-1935," ARI Working Papers Series 184 (National University of Singapore, 2012).

35. Brenda S. A. Yeoh, Contesting Space in Colonial Singapore: Power Relations in the Urban Built Environment (Singapore: NUS Press, 2012 [1996]).

36. For an insightful and in-depth analysis of the transformations of the Chinese temple and ritual system in Penang under the impact of forces of modernity, nationalism, and the hardening of ethnic boundaries, see DeBernardi, Rites of Belonging.

37. This section is based on Trocki, Opium and Empire, 116; Chen Zhakang and Monk Baoci, Gazetteer of the Penang Crane Mountain Jile Monastery.

38. On the changing discursive field in China and sinophone regions in the later nineteenth to mid-twentieth century, characterized by attacks on clericism, superstition, popular religion, and finally Buddhism, as well Daoism's role in supposedly preventing the modernization of China, see Goossaert and Palmer, Religious Question.

39. Goossaert and Palmer, Religious Question, pp. 201-209.

40. On Taixu, see Don A. Pittman, Toward a Modern Chinese Buddhism: Taixu's Reforms (Honolulu: Hawai'i University Press, 2001). On the period more broadly, see Holmes Welch, The Buddhist Revival in China (Cambridge, MA: Harvard University Press, 1968); Holmes Welch, Buddhism in China: 1900-1969 (Cambridge, MA: Harvard University Press. 1969).

41. Khun Eng Kuah-Pierce, Rebuilding the Ancestral Village: Singaporeans in China (Hong Kong: Hong Kong University Press, 2011 [1993]).

42. See the discussion of this concept in Peter van der Veer, Conversion to Modernities: The Globalization of Christianity (New York: Routledge, 1996).

43. Dean and Zheng, Ritual Alliances.

44. Dean, "Ritual Revolutions,” p. 15.

45. Kenneth Dean, "Parallel Universe: The Chinese Temples of Singapore," in Handbook of Asian Cities and Religion, edited by Peter van der Veer (Berkeley: University of California Press, 2015), pp. 257-289.

46. For a more critical perspective, see Julia C. Huang, Charisma and Compassion: Cheng Yen and the Buddhist Tzu Chi Movement (Cambridge, MA: Harvard University Press, 2009).

47. Another recent movement that has spread across Southeast Asia from its base in Taiwan is the Yiguandao. Francis Lim has examined the range of Yiguandao activities in Singapore. See Francis Lim, “'We Are Not a Religion': Secularization and the Religious Territory of the Yiguan Dao (Unity Way) in Singapore," in Proselytizing and the Limits of Religious Pluralism in Asia, edited by Julian Finucane and Michael Feener (Singapore: Springer, 2014).

48. See Marjorie Topley, Cantonese Society in Hong Kong and Singapore: Gender, Religion, Medicine, and Money, edited by Jean DeBernardi (Singapore: NUS Press, 2011).

49. Lee Chee Hiang, "Charity, Ritual and Business Networks of the Teochew Charity Halls in Singapore," Asian Culture 33 (2009): 37-55; Tan Chee Beng, "Shantang: Charitable Temples in China, Singapore and Malaysia,” Asian Ethnology 71.1 (2012): 75-107. 


\title{
SUFI “ORDERS” IN SOUTHEAST ASIA
}

\author{
From Private Devotions to Social \\ Network and Corporate Action
}

\author{
MARTIN VAN BRUINESSEN
}

\begin{abstract}
"Sufi order" is the most common English term for the formations called tariqqa (lit., "path"; Ar. pl. turuq; Ind. tarekat), and, when thinking about "orders" in Muslim Southeast Asia, it is the tarekat that first come to mind. The term "Sufi order" may be deceptive, however, in suggesting more "order" than is warranted. The word tarīqa has, at different times and places, referred to a wide variety of manifestations, and this is also true of each individual Sufi tarīqa. Currently, the major Sufi tarekat active in Indonesia, such as the Naqshbandiyya Khālidiyya and the Qādiriyya wa'l-Naqshbandiyya, are corporate bodies with a well-defined core membership and a much larger and more fluid body of irregular followers who may be and at times have been mobilized for political purposes. It is tempting but probably misleading to assume that this has been characteristic of the tariqa since their arrival in Southeast Asia. This chapter shows that the available sources tell us little about the social dimension of taríqa in Indonesia and that only from the nineteenth century onwards do we see clear examples of corporate action. Further, I argue the tarekat were not the only "order"-like formations in Southeast Asia. Communities known as putihan (people in white), consisting of more strictly practicing Muslims and distinguishing themselves in dress and habitus from the population at large, for whom they (or some of them) performed roles as religious specialists and moral exemplars, may have been a more influential disciplining force among Muslims in the archipelago in earlier periods than the tarekat themselves.
\end{abstract}

\section{SUFI ORDERS AND THE ISLAMIZATION OF SOUTHEAST ASIA}

Settlements of foreign Muslim traders had been present in the port states of Southeast Asia for centuries, but only from the fourteenth century did significant 
indigenous communities begin to adopt Islam, and it took until the sixteenth century for most of the important island of Java to be Islamized. This period of transition in Southeast Asia coincided with a time when, in the "central lands" of Islam, Sufism had evolved from an elite movement of religious virtuosi to perhaps the dominant mode of religiosity. The more popularized Sufi orders of that period offered ordinary people more or less standardized methods of cultivating devotional piety and access to at least a glimpse of mystical experience. Belief in intercession by charismatic "friends of God" (walī) capable of working miracles (karāmāt) even after their death and the visiting (ziyāra) of such saints' graves were part and parcel of this dominant mode of religiosity, although there were also some ' $u$ lama' who, like Ibn Taymiyya (d. 1328), critiqued and opposed such beliefs and practices.

It is not surprising, therefore, that early Southeast Asian Islam was strongly colored by the forms of Sufism prevalent across the broader Muslim world at that time. Conversion myths from various parts of the region explicitly mention foreign miracle-working Sufi-like figures as the prime movers of conversion. ${ }^{1}$ Several of the oldest extant Muslim texts from Southeast Asia appear infused with Sufi ethics or engage with Sufi concepts, ${ }^{2}$ and the earliest Muslim authors who are known to us by name-Hamza Fanșūrī, Shams al-Dīn Pasai, Nūr al-Dīn Rānīrī, 'Abd al-Ra'ūf Singkel, Yūsuf Makassar-were Sufis and wrote works of poetry and prose expressing Sufi religious ideas. The apparent dominance of Sufism in early (sixteenth- and seventeenth-century) Indonesian Islam does not, however, imply a lenient attitude toward sharī'a obligations, as has often been assumed. Among the oldest extant manuscripts, in Java as well as Sumatra, we also find texts on Islamic law ( $f i q h)$, and several of the greatest early Sufi authors also wrote works on jurisprudence. Indeed, in 1638, Banten's rulers sent envoys to Mekka with a triple aim: to find authoritative answers to certain metaphysical questions of Sufi cosmology, to request the title of sultan for the ruler of Banten, and to invite a leading legal scholar to come and settle in Banten as the $q \bar{a} d \underline{\imath}$ (judge). ${ }^{3}$

Several scholars have speculated about a causal connection between the flourishing of Sufi orders in the heartlands of Islam and the spread of Islam to Southeast Asia. Anthony Johns, notably, suggested in several early articles that Sufi missionaries accompanying Muslim traders might have played a key role in the process. ${ }^{4}$ Some conversion myths may be compatible with this hypothesis, but there is little other supportive evidence. It is only relatively late, from the seventeenth century onwards, that Sufi orders (tarekat) are explicitly mentioned in indigenous Indonesian sources, and they appear then in an environment that is already Muslim. The prolific author of Malay works Nūr al-Dīn Rānīrī fits the model of the foreign Sufi missionary best. He hailed from Gujarat and was of Haḍramī Arab descent, belonged to the Rifā iyya Sufi order, and was active in Aceh as the leading Muslim scholar at the court until a conflict forced him 
to leave in 1644 . However, he is especially known for his polemical campaign against the monistic Sufi teachings of earlier indigenous authors Hamza and Shams al-Dīn, whose works already reflected a sophisticated familiarity with learned Islamic discourse. Rānīrī's writings as well as those of Hamza and Shams al-Dīn addressed audiences with a considerable level of Islamic learning. Recent research has convincingly argued that Hamza flourished a half century earlier than had hitherto been assumed and died in Mekka in 1527..$^{5}$ This would mean that highly developed forms of Sufi poetry were being written in Malay more than a century before the earliest documented appearance of Sufi "orders" in the region. This chronology appears to make the hypothesis of Sufi orders as a major factor in the early Islamization of the region untenable, though they may well have played a crucial role in later stages. ${ }^{6}$

The most renowned Muslim scholars of seventeenth-century Southeast Asia - Nūr al-Dīn Rānīrī, 'Abd al-Ra'ūf Singkel, and Yūsuf Makassar-explicitly state their adherence to various tarīqa and also document their silsila (chains of transmission). Rānīrī's primary affiliation was with the Rifā' iyya, into which he was initiated by another Arab of Haḍramī descent resident in Gujarat, 'Umar Bā Shaybān. N Nūr al-Dīn's uncle Muḥammad Jilānī Rānīrī had preceded hìm as a teacher in Aceh. (Nūr al-Dīn relates how his uncle, after having taught Islamic law in Aceh for a few years, traveled to Arabia to study Sufi metaphysics, because this is what the Acehnese demanded to learn, and returned then as a Sufi teacher.) When on his way from Makassar to Arabia, Yūsuf spent time in Aceh and was initiated into the Qādiriyya by either Nūr al-Dīn or his uncle (the names are conflated in Yūsuf's account). ${ }^{8}$ The first part of Yūsuf's Qādiriyya silsila mentions the same 'Umar Bā Shaybān, and for several generations it is practically identical with Rān̄̄r̂̀’s Rifā' iyya chain. Bā Shaybān's predecessors in that line belonged to the al-Aydarūs family, which had been resident in Gujarat for several centuries and appears to have been teaching both the Rifā iyya and the Qādiriyya as well as their own family țarīqa, the Aydarūsiyya. The presence of the Rifā iyya and Qādiriyya in Aceh in later years and their impact on popular religious practices are well attested, but it is not clear whether this is because of the influence of the Rānīrīs or from later incursions of the same tarīqa.

'Abd al-Ra'üf spent almost two decades in Arabia studying with the most prominent scholars of the time, and he was especially close with Ahmad al-Qushāshī (d. 1661) and his successor Ibrāhīm al-Kūrānī (d. 1690), both of whom were widely regarded as the leading scholars of Medina. Both had reputations as hadith scholars and taught a broad range of Islamic sciences, including several tarīqa. Qushāshī appointed 'Abd al-Ra'ūf as his khalīfa for the Shațāariyya, which he taught after his return to Aceh (probably in 1661), along with the metaphysical ideas associated with it. Qushāsh̄̄ and Kūrān̄̄ figure prominently in all later Shattārī silsila found in Sumatra and Java. In some, the line passes through 'Abd al-Ra' ûf and one of his deputies; in others, a later 
Indonesian student is connected with Kūrān̄̄'s son or grandson or a later successor in Medina. (Kūrān̄̄ also figures in Naqshbandī silsila, showing he initiated other Indonesians into this țarīqa rather than the Shațtāriyya.)

Like 'Abd al-Ra'ūf, Yūsuf Makassar spent many years in Arabia studying with an equally impressive range of scholars from Yemen to Syria, and he was likewise initiated into several other țarīqa. Besides the Qādiriyya, he gives his silsila for the Naqshbandiyya, Shaț̣āriyya, Bā 'Alawiyya, and Khalwatiyya. His Shațāāiyya teacher was Ibrāhīm al-Kūrānī, and his silsila therefore is practically identical with 'Abd al-Ra'ūf's. He became known primarily as a teacher of the Khalwatiyya, which he had taken in Syria, but he appears to have combined the specific techniques of this tariqa with those of others, notably the Naqshbandiyya. He probably returned to Indonesia sometime in the 1660s; in 1672 we find him settled in Banten and rapidly gaining influence and power at the court. He appears to have taught his tarīqa only to members of the nobility of his own ethnic group, the Makassarese. Known as Khalwatiyya Yūsuf (to distinguish it from a later incursion of the order, Khalwatiyya Sammān), it is still present in South Sulawesi and retains its somewhat aristocratic character. ${ }^{9}$

There is one Indonesian source that hints at an earlier, sixteenth-century, arrival of Sufi orders, although this source is itself of a later date. The Banten court chronicle Sajarah Banten Ranté-Ranté or Hikayat Hasanuddin, which must have been compiled sometime between 1662 and 1725, relates how the founder of the Muslim polity of Banten, Maulana Makhdum alias Sunan Gunung Jati, spent decades studying in Mekka and Medina and was initiated there into several tarīqa: the Kubrawiyya, Shādhiliyya, Shațtāriyya, and Naqshbandiyya. Most interestingly, this text lists the most important names of the silsila of two distinct Kubrawiyya branches as those of fellow students of Sunan Gunung Jati. The text lists no later representatives of this țarīqa than 'Abd al-Laṭif Jāmī, who visited Mekka in 1547-1548, and Aḥmad Shinnāwī (d. 1619), who was Qushāshī's predecessor as the leading scholar of Medina. This suggests that some Bantenese must have been aware of the Kubrawiyya and possibly initiated in it in Mekka and Medina at different points between 1547 and 1619.10

\section{SUFI ORDERS IN THE CENTRAL LANDS OF ISLAM IN THE SEVENTEENTH CENTURY}

In what still remains the major general overview of Sufi orders, J. Spencer Trimingham sketches their historical development as a simple linear progression along three stages of increasing systematization of spiritual techniques, increasing degree of organization, and incorporation of increasing numbers of followers. Trimingham associates the first stage with the khānaqā, or Sufi lodge, in which a master lived with his close disciples; the second with the tariqa in the restricted sense, as "continuative teaching schools of mysticism" characterized by "new types of collectivistic methods of inducing ecstasy"; and the third stage 
with the emergence of "corporations" or "orders" proper, for which he uses the term $t \bar{a}$ 'ifa (group, collectivity). ${ }^{11}$

Such a highly simplified model of major trends can be helpful as long as we are aware that in reality the developments were neither uniform nor unilinear. However, it may make more sense to look at the three ideal types of Trimingham's stages as different aspects of any single tarīqa: the physical institutions, the chain of transmission and standardized package of spiritual techniques, and the social organization. Sufi "lodges" (named khānaqā, zāwiya, or tekke in different contexts) remained important institutions until very recently, but there has always been wide variety in their functions. ${ }^{12}$ Initially, the khānaq $\bar{a}$ and zāwiya were primarily associated with their founders (princes, governors, rich merchants) or the individual shaykhs heading them. ${ }^{13}$ In later stages, they became associated with specific Sufi orders or lines of affiliation. It could happen that a lodge belonging to one order was taken over by (or handed over by the state to) another, but independent lodges were virtually nonexistent.

Trimingham's second stage was the crucial one in which chains of affiliation with the founders of distinctive spiritual traditions emerged. Virtually all tariqa are named after the founder or a reformer of this tradition, and the masters and disciples of the tariq a are connected by a silsila, a chain of masterdisciple relations, to this founder and thence to the Prophet. Each of these paths consists of distinctive spiritual techniques, which can be carried out privately or collectively: recitation of the divine names (dhikr), litanies (wird, rātib), supplications ( $\left.d u^{\prime} \vec{a}\right)$, and various forms of meditation. The silsila is central to the concept of a Sufi order; it constitutes the genealogical legitimation of the master and his teachings, and it connects him with the saintly predecessors whose reputations define the spiritual tradition of the particular tarīqa.

The silsila is also a formative structural element of the social organization of the Sufi order. An influential shaykh who appoints several khalifa, who in turn appoint their own to other places, is at the center of a network of local congregations, which is, as it were, a geometrical representation of the khaliffa's combined silsila. Originally unconnected groups of devotees may, moreover, become part of the network by submitting themselves to the shaykh or a khalifa and rearranging their silsila accordingly. ${ }^{14}$

Two other practices were important to the organizational aspect of the tariqa: the bay'a, or vow of loyalty and obedience, which marks the formal moment of entry into the order, and the ijāza, or license to practice the techniques of the order. In most orders, there were different degrees of membership (Trimingham speaks of "adepts" and "affiliates") and a hierarchy of $i j a \bar{z} a$ (to practice, to lead communal rituals, to induct new members into the order).

By the fifteenth century, several of the major Sufi orders-Qādiriyya, Khalwatiyya, Suhrawardiyya, and Rifā iyya - consisted of networks of local groups of practitioners spread all over the central Islamic lands, from Egypt to India. The Kubrawiyya and Naqshbandiyya, then still Central Asian orders, 
rapidly expanded to the south and west in the sixteenth century, and the latter especially would henceforth be one of the most influential and most strongly connected orders. ${ }^{15}$ The Chishtiyya and Shațāariyya were originally and long remained Indian orders and the Shādhiliyya, a North African order; they gained a presence in Mekka or Medina when scholars from these regions settled there as teachers. The degree of organization of these orders is difficult to gauge from the sources. Some were no doubt more like corporations than others. ${ }^{16}$ Some of the orders were centralized, and the authority of the central lodge or supreme master was recognized by other local communities. This was especially the case where a state supported the central authority of the tarīqa. The major orders, however, transcended state boundaries and were at best partially centralized. Men like Shinnāwī, Qushāshī, and Kūrān̄̄ in Medina, who were among the most famous scholars of their time and who held teaching ijäza for a handful of different tarīqa, would not have been subjected to any one order's higher authority. It is not clear whether they actually headed zâwiya and regularly led collective rituals; since this would seem to imply a more unique affiliation with a single tarīqa, it may not have been the case.

\section{WHAT CHARACTERIZED A TARĪQA IN SEVENTEENTH-CENTURY INDONESIA?}

What the seventeenth-century scholars Rānīrī, 'Abd al-Ra'ūf, and Yūsuf write about their tarīqa is limited to their silsila and a few general prescriptions concerning the performance of $d h i k r$ and other ritual recitations. Yūsuf prescribes different recitations for beginners and the advanced, the latter progressing from the vocalization of the first sentence of the "profession of faith" ("There is no god but God"/Ar. lā ilāha illā llāh) to Allāh, Allāh, and finally $H \bar{u} H \bar{u}$ ("Him, Him"), and explains how the syllables of the first-named $d h i k r$ should be "drawn" through the body, dragging a lengthened $l \bar{a}$ of negation from the navel up to the brain, then the ilāha to the right shoulder, with one pause briefly before moving to the left, hammering illa llāh into the heart with great force. ${ }^{17}$ 'Abd al-Ra'ūf gives similar, but more elaborate, descriptions of $d h i k r$ in several of his treatises, while adding that oral instruction by the murshid (spiritual guide) is essential for correct practice. ${ }^{18} \mathrm{He}$ also describes the wird to be recited after the five daily prayers and the rātib litanies recited in meetings on the eve of Friday and Tuesday. ${ }^{19}$

'Abd al-Ra'üf's instructions for the rātib are the only indication that he adhered to collective Sufi rituals (the instructions are explicit about the alternating of the imam's singing and the congregation's response). There is reason to question, however, whether this collective ritual was specifically associated with the tariqqa and performed by initiated followers only. 'Abd al-Ra'üf may have introduced it as a meritorious practice for the community at large. In later years, the $r \bar{a} t i b$, in the louder and more ecstatic form associated with the Sammāniyya 
that reached Aceh a century later, eventually became a form of popular entertainment that lost much of its original Sufi devotional connotation. ${ }^{20}$ In the late nineteenth century, as Snouck Hurgronje explicitly notes, these performances were very different from the less conspicuous Shattārī devotions, which were usually recited individually, not collectively. ${ }^{21} \mathrm{He}$ also notes that there were very few adepts of the Shațāariyya in Aceh, but there was a lively cult centered on 'Abd al-Ra'ūf's grave. ${ }^{22}$

'Abd al-Ra'ūf appointed two deputies (khalīfa), whose graves also became major pilgrimage centers in the Indonesian archipelago: the Minangkabau scholar Burhān al-Dīn in Ulakan in Pariaman, West Sumatra, and the Javanese 'Abd al-Muhȳi in Pamijahan, West Java. All three graves attract numerous visitors, but few of them are actually affiliated with the Shattāiriyya. ${ }^{23}$ In West Sumatra and in West and Central Java there are, however, a number of small congregations of Shatțāriyya adepts and affiliates that trace their genealogies through one these two khalīfa and 'Abd al-Ra'ūf to Qushāshī. The relatively large number of Shațāiriyya manuscripts containing silsila mentioning Burhān al-Dīn or 'Abd al-Muhyyī indicates that both established self-perpetuating lines of Shațāariyya transmission. Other Shațāāī silsila from Java reflect later initiations by descendants or successors of Ibrāhīm Kūrānī in Medina. ${ }^{24}$

In both Sumatra and Java, the name of the Shattāiriyya is especially associated with popularized versions of the theory of divine emanation in "seven grades [of being]" (martabat tujuh) that, grafted onto indigenous cosmological ideas, became fundamental to numerous later esoteric movements as well as magical practices. Actual initiation into the tarīqa Shațāriyya, however, appears to have remained limited to small numbers of adepts and affiliates. In Java, the court of Cirebon stands out as the major center of Shattāiniyya teaching. There appears to have been a direct connection between 'Abd al-Muhyī and the Cirebon court; some oral traditions claim he married a Cirebon princess, and several silsila in Cirebon manuscripts mention him as the fountainhead of the Shattāariyya in Java (but others claim a later introduction directly from Medina). The tariqqa later - in the late eighteenth or early nineteenth century - also began to be taught by the major pesantren (sites of Islamic learning) of the Cirebon region but until then appears to have remained restricted to court circles. ${ }^{25}$

The same appears to have been true of the other tarekat (tariqa) appearing in Indonesia in the seventeenth century and well into the eighteenth. Nūr al-Dīn Rānīrī and 'Abd al-Ra'ūf were the leading Islamic scholars at the court of Aceh. Yūsuf Makassar came to play the same role at the court of Banten and corresponded with a prince of his native Gowa on matters of politics and mysticism. The most prominent țariqa teacher of the mid-eighteenth century, 'Abd Allāh b. 'Abd al-Qahhār, who had received ijāza to teach the Shatțāriyya and Naqshbandiyya from Ibrāhīm Kūrān̄̄'s second or third successor in Medina, was himself a member of Bantenese court circles. Cirebon court elites received Shattāāi ijāza from him, but he also appointed three Naqshbandī khalīfa to the 
Bogor-Cianjur region. The latter three were hajjis but may have been well-to-do commoners rather than court aristocrats. ${ }^{26}$

These men probably restricted their teaching of the tariqa to those who had sufficient knowledge of Islamic doctrine and understanding of Sufi metaphysics. Courtiers may have had other reasons to prevent instruction in the tariqa from reaching the masses. As the Hikayat Hasanuddin and the Babad Cerbon strongly suggest, the various tarīqa were considered as sources of occult knowledge (ngèlmu) that served to supernaturally support as well as to legitimize the ruler's control of his realm and to provide protection from all sorts of danger. In martial arts circles, it is still believed that the tariq a-derived techniques of cultivating extraordinary strength (tenaga dalam) and invulnerability (kekebalan) were long jealously guarded as a monopoly of the courts.

All these men actively taught one or more țariqa rather restrictively. They appointed only a few khaliffa, and did not induce large numbers of novices into their tarīqa. There are no references in our sources to zāwiya or similar physical institutions and no indication the tarīqa was a sort of association with members acting in concert (but we cannot conclude from the silence of our sources that collective rituals or other communal action did not take place). Judging by their extant writings, all of these men devoted more effort to the elucidation of mystical doctrines and their harmonization with Islamic orthodoxy than to instruction in the practical exercises of the tariqa. There was clearly a local demand for authoritative explanations of these doctrines. As mentioned above, one of the tasks of the embassy the court of Banten sent to Mekka in the seventeenth century was to find such explanations. ${ }^{27}$ A few decades later, Ibrāhīm Kūrānī wrote his Ithā $f$ al-dhaki in response to debates that had arisen in Indonesia over the interpretation of Burhānpūrī's widely read popularizing work on wahdat $a l-w u j \bar{u} d .{ }^{28}$ Such writing was directed at an intellectual elite, which must have been mostly based at the courts.

After these Sufi authors' deaths, cults developed around their graves, and it became common to invoke their intercession and supernatural protection. These popular practices had but a tenuous link with the tariqa they taught and practiced. It is perhaps significant that in late nineteenth-century Aceh, Nūr al-Dīn Rānīrī was not remembered for the tarīqa he had taught himself, but his name was invoked in a rātib associated with the Sammāniyya order, which represents a later phase in Indonesian Sufism. ${ }^{29}$

\section{ENTER THE MASSES}

The first indigenous reference to what looks like mass participation in tariqa activity is in a Malay text from Palembang, the Syair Perang Menteng, which describes events that took place in 1819, when a Dutch military force commanded by the recently appointed governor Herman Warner Muntinghe ("Menteng") prepared to attack and conquer the sultanate. The syair describes 
how a large group of men dressed in white ("hajjis," according to the text) worked themselves into a trance by reciting dhikr ("hammering the words $l \bar{a}$ ilāha illā llāh into their hearts"), raised their frenzy by loudly shouting a rātib, and fearlessly attacked the militarily superior Dutch force. Invoking the most powerful of God's names, they fearlessly gave battle and dispersed the attackers. ${ }^{30}$ The "hajjis" appeared to believe that the dhikr and râtib they recited loudly, accompanied by wild physical movements, gave them supernatural strength and virtual invulnerability.

As the Dutch expanded their territorial control of the archipelago in the nineteenth century, they repeatedly came up against similar "fanatical" resistance, in which people prepared themselves for battle by collective Sufi rituals of dhikr and rätib. In the 1860s, an anti-Dutch uprising in South Borneo reportedly became a more serious threat when people en masse performed bay' $a$ with a tariq $a$ teacher, who taught them a rātib and gave them amulets for invulnerability. For decades, this beratib beamal movement, as it was locally known, was the major expression of common people's resistance to Dutch advances. ${ }^{31}$

Although the sources do not mention any specific tariqa in this connection, it is almost certain that in both Palembang and South Borneo they were connected to the Sammāniyya, a "new" order known for its loud, rhythmic rātib and ecstatic dhikr. ${ }^{32}$ Its founder, Muḥammad b. 'Abd al-Karīm al-Sammān (d. 1775), was one of the great scholars teaching in Medina who developed a synthesis of various mystical traditions. His Sammāniyya is based on the Khalwatiyya, with the addition of various elements borrowed from other orders, notably the Qādiriyya and the Naqshbandiyya. It has some features unique to it, such as a loud dhikr beginning with divine names but then proceeding to apparently meaningless sounds. ${ }^{33}$ After his death, he acquired a reputation for supernatural intervention only second to that of 'Abd al-Qādir Jīlānī.

The Sammāniyya rapidly spread to many parts of Southeast Asia owing to the mediating role of the learned 'Abd al-Șamad Palimbān̄̄, a protégé of the Palembang court who spent most of his life in Arabia, studying, teaching, and writing Malay books that were to become the most widely read texts on Sufism in Southeast Asia. Numerous Southeast Asians who spent time studying in Arabia during the second half of the eighteenth century were 'Abd al-Samad's students, studying at least some texts of fiqh and other disciplines under his supervision. ${ }^{34}$ He was also one of Sammān's khalīfa and must similarly have instructed many in the $d h i k r$ and $r a \overline{t i b}$ of the Sammāniyya or have pointed them to Sammān himself and later to his chief khalīfa in Medina, Șiddīq b. 'Umar Khān. All three of these shaykhs appointed Muslims from Southeast Asia as khalīfa. The Palembang court patronized the Sammāniyya, and a year after Sammān's death the sultan of Palembang had a Sammān̄i zāwiya built in Jeddah for the benefit of his subjects who made the pilgrimage. ${ }^{35}$ The construction of this zāwiya is mentioned in the Malay adaptation of the Arabic hagiography of Sammān that was probably composed in Palembang not long 
after his death and copied in many parts of the archipelago. Within decades, the Sammāniyya was known not only in Palembang, but also in Batavia and Banten, Aceh, Patani, South Borneo, and South Celebes (where it was known as Khalwatiyya-Sammān). ${ }^{36}$

The Sammāniyya had bay'a, but its $d h i k r$ and rātib were also recited by many who had no formal affiliation with the order. Membership was not a strict condition for participation. Some Indonesian teachers of the order appointed their own khaliffa, resulting in a certain hierarchy of organization and the possibility of corporate action. The Sammāniyya's role in anti-Dutch resistance made it more conspicuous, but in most places the collective dhikr and rātib were not connected with any form of political mobilization. The Sammāni rātib developed in some regions into a form of popular entertainment or folk performance; elsewhere it was adopted by martial arts groups as an invulnerability technique, in which Shaykh Sammān was called on along with 'Abd al-Qādir Jīlān̄̄ and A himad Rifā' $i$ to protect their devotees from the effects of cutting iron, scorching fire, and noxious poison. ${ }^{37}$ Compared with the tariqa of the seventeenth century, the Sammāniyya appears less aristocratic and more activist. Its networks spread more rapidly and more pervasively among the population at large, and in many places its rituals merged with popular culture.

In the second half of the nineteenth century, the Sammāniyya was gradually eclipsed by the Qādiriyya wa'l-Naqshbandiyya, a similar "new" tariqa founded by the Mekka-based Malay scholar Aḥmad Khațîb Sambas (d. 1875) and successfully propagated in Java by three khalif $a$ based in Banten, Cirebon, and Madura. Like the Sammāniyya (and several other "new" tarekat emerging in the nineteenth century), this tariqa combined a number of distinct traditions into a new synthesis. ${ }^{38}$ Earlier scholars such as Qushāshī and Kūrānī had also taught a number of different tarīqa, but these remained distinct and had each its own silsila. Some students were taught one țariqa, others a different one. Sammān and Aḥmad Khațīb, in contrast, taught an integrated package in which the components could no longer be separated. Another common trait is that both founders were legal scholars as well as mystics, and their new orders combined ecstatic practices with strict adherence to the sharīa. Both orders also eventually found their major following outside court circles - whereas the Sammāniyya had initially been patronized by the Palembang sultanate, the Qādiriyya wa'l-Naqshbandiyya had no royal patrons. Aḥmad Khațīb's chief khalïfa in Banten and Cirebon may have belonged to families with historical court connections, but they were based in pesantren outside the center and spread the order among the rural population of the hinterland through a network of lower-ranking deputies.

As in the case of the Sammanniyya, much of our knowledge about the popular following of the Qādiriyya wa'l-Naqshbandiyya stems from the fact that the order was implicated in a number of uprisings against Dutch rule (or, rather, against the indigenous elite that collaborated with the Dutch). The great 
rebellion of Banten in 1888 occurred against a background of economic discontent and what the historian Kartodirdjo believed to be a religious revival, in which the Qādiriyya wa'l-Naqshbandiyya provided an institutional framework for communication and solidarity. The man who had been Ahmad Khațīb's khalïfa in Banten, Shaykh 'Abd al-Karīm, was at that time residing in Mekka, where he had succeeded his teacher as the titular head of the order. Neither he nor his local deputies had been involved in the preparations for the uprising, but no doubt many of their followers took part in it. The loud dhikr and amulets made by khalīfa or other men of religion may have strengthened people's daring and belief in their invulnerability. We find the order in the background of several other revolts of the late nineteenth century as well. ${ }^{39}$ In other regions, where there were no such uprisings connected to aspects of Sufism, it may well have also been present without being noticed. In the twentieth century, the Qãdiriyya wa'l-Naqshbandiyya developed into three well-organized and centralized networks together covering all of Indonesia and Malaysia, with hundreds of thousands of followers and hundreds of local groups regularly meeting for collective dhikr and other rituals. ${ }^{40}$

\section{IN SEARCH OF AN EXPLANATION: WHAT HAD CHANGED?}

There are some remarkable differences between the manifestations of the Shațāriyya, Khalwatiyya, and Naqshbandiyya in the seventeenth and eighteenth centuries and those of the Sammāniyya and Qādiriyya wa'1Naqshbandiyya in the nineteenth. Most notably, there appears to have been a pronounced increase in the degree of organization and popular participation. Here one cannot help being reminded of the second and third stages in Trimingham's three-stage model of the development of Sufi orders. All these orders were "continuative teaching schools of mysticism" that offered "collectivistic methods of inducing ecstasy" (as in Trimingham's second stage), but only the last two were to some extent "corporations" (third stage). A satisfying explanation for these apparent transitions and transformation, however, does not easily present itself. We have little sociological information about the earlier period, and it is conceivable that there was more organization and mass participation than was recorded in our sources for the earlier period. Assuming that the perceived differences cannot entirely be reduced to the uneven quality of our sources, however, explanation should be sought in either changes in the tariqa as they functioned in Arabia or changes in Indonesian society that enabled the tariqa to play new roles. I have pointed out some differences between the "new" orders and the older ones, but it is hard to see how these could have been the major cause of the former's greater popularity in Indonesia. Moreover, the Sammāniyya and the Qādiriyya wa'l-Naqshbandiyya did not experience a similar expansion elsewhere in the world (with the partial exception of the Sudan in the case of the Sammāniyya). 
Therefore, it is necessary to seek relevant developments in Indonesian and Southeast Asian society generally that may have been causal factors. The obvious and most conspicuous change in Indonesian society was the colonial powers' expanding territorial control. ${ }^{41}$ Colonial control brought in its wake a number of other changes that may have been more directly relevant for an expanding role of the Sufi orders. The various sultanates, which had been patrons of Sufis and scholars, lost much of their former power over the course of the nineteenth century. The sultanate of Banten was actually abolished in the early nineteenth century. Many others survived but were placed under Dutch suzerainty, and their control of land and people continued to decline. There were substantial changes in the infrastructure of the archipelago. Roads were built, and communications between previously isolated communities improved over the course of the nineteenth century. Scholars returning from study in Mekka established simple pesantren not at the court but in rural areas, interacting with a very different population. From the late eighteenth century through the nineteenth, the number of pesantren and their students gradually increased. ${ }^{42}$ Tarekat and their teachers offered the rural population alternative sources of authority, partly replacing that of the court. There had always been persons and places of spiritual authority in the periphery, independent of the courts, but the development of pesantren significantly increased their number at a time of increasing colonial pressure on the authority of the archipelagic courts. The pesantren itself is, primarily, an institution in which children are taught to read kitāb, religious texts. Some of the same teachers also provided services for adults, in the form of communal rituals involving the reading of devotional texts, supplications, rātib, and $d h i k r^{43}$

The expanding pesantren network in Southeast Asia was directly related to another development in Mekka: the emergence of a large community of resident "Jāwa," or Southeast Asians, many of them, but by no means all, scholars. ${ }^{44}$ There is reason to believe, as I shall explain below, that the presence of a significant number of Jāwa teaching in Mekka was a relatively recent phenomenon, emerging not long before the nineteenth century. These scholars, even when teaching Arabic texts, would give explanations in Malay or Javanese. Their presence made it possible for men with limited command of Arabic to gain prestigious knowledge in Mekka quickly, within one or two years. Men like 'Abd al-Ra' ūf Singkel and Yūsuf Makassar had had to spend decades in Arabia before returning to Indonesia as teachers. The presence of Jāwa scholars (as well as Jāwa assistants to scholars and Sufis for the benefit of Jāwa students) made shortcuts possible for later generations. The number of Jāwa students increased, and on average they spent much less time in Arabia.

Intriguing indications about the dynamics of this community can be glimpsed from the chains of transmission (isnād) of the books they studied. The isnād are very much like the silsila of a tariqua and have the same legitimating function. In the traditional educational setting, face-to-face contact was 
essential even in teaching written texts; a student who had completed the study of a particular text received an ijāza for this text from his teacher, usually with the $i s n \bar{a} d$, the chain of preceding teachers, attached. It was not unusual for scholars to write intellectual autobiographies that consisted almost entirely of isnād for the major books they had studied and silsila of the tariq $a$ with which they were affiliated. ${ }^{45}$ The man who was considered the leading Indonesian traditionalist scholar in Mekka in the late twentieth century, Shaykh Yāsīn Padang (d. 1990), was a great collector of isnād and published several books containing nothing but his isnād for all the major works of fiqh, hadith, tafsìr, and other disciplines. ${ }^{46} \mathrm{~A}$ preliminary analysis of this corpus yields some interesting findings relevant to the history of Indonesian tarekat. Shaykh Yāsīn had studied with many different teachers, and even books studied under the same teacher usually had quite different isna $\bar{d}$, indicating that the previous generation of teachers also had sought knowledge with a variety of authorities. However, some of the same names recur in many isna $\bar{d}$, suggesting that these were the leading authorities of their generation. During the entire nineteenth century, Southeast Asian names predominate among these authorities, with a sprinkling of famous Arabs, giving the impression of a tightly woven community of Jāwa scholars, mostly studying under other Jāwa and only a few of them directly under Arab scholars. In the mid-nineteenth century, for instance, the famous Nawāwī Banten constitutes a distinct node in the Jāwa scholarly networks. He taught many texts to numerous students. However, the key position in the networks belongs to 'Abd al-Șamad Palimbānī of the earlier nineteenth century, who transmitted a wide range of texts, in all Islamic disciplines, from a variety of mostly Arab teachers to numerous Jāwa students. He appears to stand at the beginning of a self-perpetuating scholarly community of Jāwa in Mekka.

Back in the seventeenth century, 'Abd al-Ra'ūf Singkel and Yūsuf Makassar may also have acted as mediators for the other Jāwa studying in Arabia in their time. It is claimed that Yūsuf's future chief khalī $f a$ had been with him in Arabia, for instance, and that 'Abd al-Ra'ūf communicated with Ibrāhīm Kūrānī on behalf of other Jāwa. However, the next few generations traveled to Arabia to study under the (non-Jāwa) successors of Kūrānī and his colleagues. The situation in the nineteenth century was quite different. The study of texts had become easier, as there were enough teachers who could give explanations in Malay, and practical training in the techniques of a tarīqa was also available in languages of Southeast Asia. There was a zāwiya of the Sammāniyya in Jeddah, where presumably Malay was spoken, and the learned founder of the Qādiriyya wa'lNaqshbandiyya was himself a Jāwa resident of Mekka, Aḥmad Khațīb Sambas, who personally initiated "thousands of pilgrims and residents, from all parts of the East Indies." ${ }^{, 47}$

With the increasing numbers of pilgrims from Southeast Asia, many of whom wished to return home with an ijäza obtained in Mekka, there was such a demand for initiation in a tarīqa that by the mid-nineteenth century even some 
non-Jāwa teachers were beginning to specialize in training Jāwa students. The (Turkish and Daghistani) shaykhs of the Naqshbandiyya Khālidiyya order in Mekka had a staff of Malay, Javanese, and Sundanese assistants and translators in order to be able to serve as many customers as possible. Snouck Hurgronje, following his informants, writes in scathing terms of the Naqshbandī zāwiya in Mekka as a commercial enterprise in which quality was sacrificed to quantity. His judgment may, however, have been influenced by the fact that the first prominent Indonesian teacher belonging to this branch of the Naqshbandiyya, Ismā' $\overline{1}$ l Minangkabawī, had been a "rather learned but very fanatical" man, that is, a fierce opponent of infidel rule over the Indies. ${ }^{48} \mathrm{Be}$ that as it may, the Naqshbandiyya Khālidiyya also experienced very rapid development in Indonesia and became perhaps the most highly organized of the orders there.

\section{THE TTARIQQA AS A CORPORATION: NAQSHBANDĪ VILLAGE OF BABUSSALAM, LANGKAT, NORTH SUMATRA}

In this history of increasingly structured organization of Indonesian tarekat, one pivotal figure was Shaykh Sulaymān al-Zuhdī, who led the Naqshbandī $z \bar{a} w i y a$ on the hill of Abu Qubays in Mekka during the last quarter of the nineteenth century. He was not the first Mekkan teacher of this order to gain influence in Southeast Asia, but he was the most prolific. His predecessors, Sulaymān al-Qirīmī and 'Abdallah al-Arzinjānī, assisted by their Malayspeaking deputy Ismā'îl Minangkabawī, had presided over the first expansion of the Naqshbandiyya Khālidiyya in Java and Sumatra, but it was especially al-Zuhdī who systematically appointed khaliffa to all parts of the archipelago. ${ }^{49}$ A brief basic training followed by a twenty- or forty-day retreat (khalwa or sulūk) in the zâwiya under the close supervision by the shaykh or his assistants was apparently sufficient to warrant an $i j \bar{a} z a$. This abbreviated program of initiation proved to be a significant factor in the expansion and popularization of the order in the late nineteenth and early twentieth centuries.

Most of Sulaymān Zuhdī's Indonesian khalīfa only held ijāza to lead the dhikr and induce novices into the order but not to appoint their own deputies or successors. This meant that each new generation needed to request its $i j \bar{a} z a$ from Mekka, which thereby remained the de facto center of the Southeast Asian Naqshbandī networks. A few trusted khalīfa, however, were also given ijāza to appoint their own deputies. One of them was a Malay from Central Sumatra who went on to become the most prolific Indonesian tarīqa teacher ever: 'Abdul Wahab Rokan. He had studied under Shaykh Sulaymān al-Zuhdī, who had given him authority to develop the order over all of North and East Sumatra, from Aceh to Palembang, and this he did. He traveled extensively in this region, was welcomed everywhere as a man of special gifts, concluded strategic marriages with women of influential families, and inducted members of the local elites 
into the tarīqa. Between his return to Sumatra in 1868-1869 and his death in 1926, he married at least twenty-seven women, begot forty-three children, and appointed around 120 khaliffa in this region and across the straits in Malaya. ${ }^{50}$ 'Abdul Wahab gained the favors of many of the local rulers throughout the region, including the sultans of Langkat and Deli, who were the most prominent indigenous authorities on the east coast of Sumatra. Sultan Musa of Langkat, who was attracted to the religious life and who was affluent through his pepper plantations, became his chief benefactor. After a number of shorter visits, during which the shaykh had taught the dhikr and led retreats (sulük), the sultan invited him in 1877 to settle permanently at the court in Tanjung Pura and a few years later endowed a large tract of land as waqf for the shaykh to develop as a center of the Naqshbandī order.

The shaykh had arrived with wives and children and a following of some 150 people from various parts of Sumatra, most of them Malay and Mandailing Batak. These were the first settlers of the village that was built on the waqf land, which the shaykh named Babussalam. The center of the village was (and is) the large mandarsah (lit., "school"), a brick mosque with a separate space for $d h i k r$ above the prayer hall. Separate from the mandarsah there were two rumah suluk (Ar. sulük), houses for retreat, large wooden barracks partitioned by cloth screens into small cells where men and women from all over the east coast would come for the ten-, twenty-, or forty-day retreats that are a special feature of the Nashbandiyya Khālidiyya. As more followers of the shaykh continued arriving, the village grew to a size that was economically self-sustaining.

Under 'Abdul Wahab's direction, the residents of Babussalam planted various cash crops on the waqf land - fruit trees, coffee, pepper, rubber-and raised animals. All had to contribute time and effort to the common enterprise, and the village economy flourished. The shaykh wrote an elaborate "constitution" (peraturan-peraturan) for the village, which stated that only active followers of the Naqshbandiyya could settle there, and access was completely denied to non-Muslims. All residents had to wear distinctive white headgear that made them stand out from the surrounding society. Space and time were patterned by voluntary work and devotions, as the entire village participated in the daily prayers and dhikr. At dawn and sunset, the call to prayer from the minaret was preceded by a long munājāt (supplication) invoking all the saints of the Naqshbandī silsila. ${ }^{51}$

As an economic enterprise, Babussalam was self-reliant and a contributor to the economic growth of the larger region, but it was also embedded in a network of economic transactions that reflected the hierarchical relations between teacher and disciple, and thereby the centralized structure of the Naqshbandiyya Khālidiyya țarīqa. 'Abdul Wahab had been poor when he returned to Sumatra, but his reputation as a man of extraordinary qualities and patronage by the rich and powerful soon made him prosperous. He had earlier built a more modest 
village in Kubu, a district of Riau, from which he had begun his teaching. Disciples and visitors brought gifts in money and kind according to their abilities, which soon amounted to a considerable annual income. As soon as he could afford it, he sent each year large sums of money as gifts to his teachers in Mekka, especially Sulaymān al-Zuhdī. ${ }^{52}$ Once he had gained the patronage of the rich Sultan Musa of Langkat, he persuaded the latter to perform the hajj and introduced him to al-Zuhdī. The sultan performed a retreat under al-Zuhdī and received an ijāza as khalīfa. He had a mosque built close to al-Zuhdī's $z \bar{a} w i y a$, which he donated to the shaykh, and houses for other teachers of 'Abdul Wahab's network. ${ }^{53}$

The large rumah suluk in Babussalam attracted a steady stream of visitors who came to perform a retreat under the shaykh's guidance, bringing such gifts as they could afford. Especially in the quiet period following the harvest, villagers from far away traveled to Babussalam for ten- or twenty-day retreats. Sulük or khalwa was a practice known in other orders too, but it had been adopted as one of the central practices for adepts of the Naqshbandiyya Khālidiyya order by the reformer Mawlānā Khālid. ${ }^{54}$ It involved a regime of isolation, fasting, and entire days spent in $d h i k r$ and meditation. Whereas every khalïfa was allowed to lead communal dhikr sessions, the supervision of sulük demanded a higher level of spiritual attainment recognized by a different type of ijāza. The network of ritual halls for these observances (rumah suluk) thus contributed to keeping the network of local Naqshbandī branches relatively centralized. There was, moreover, a hierarchy of rumah suluk and khalifa, as was to be seen in the case of Sultan Musa's visit to Mekka. For ambitious adepts, spiritual progress corresponded with a rise along this hierarchy, from training by one or more local khaliffa to a number of retreats in Babussalam, and culminating in a retreat in the Mekkan zāwiya of Abū Qubays.

The centralized structure of the order was further underlined and maintained by the Naqshbandī meditation technique called rābita or rābita bi'lshaykh, in which the murīd closes the eyes and visualizes the master, in order to establish a spiritual connection with the master and through him to the earlier masters of the silsila up to the Prophet. Mawlānā Khālid demanded that all disciples and even later generations perform the rābita directly with him (rather than with one of his khalīfa). Sulaymān al-Zuhdī, who was a third-generation khalīfa of Mawlānā Khālid, required his disciples and khalīfa to visualize Mawlānā Khālid. A notebook brought back by an Indonesian pilgrim who had received an initiation in Sulaymān al-Zuhd̄̄'s zāwiya contained, besides many other notes on Naqshbandī techniques, a brief description of Mawlānā Khālid's facial features as an aid to visualization. ${ }^{55}$ All of 'Abdul Wahab's disciples were instructed to visualize Mawlānā Khālid each time they meditated and thereby maintained a strong connection with the center. It was only after the ties with Mekka had been cut owing to the second conquest by the Wahhabis that Indonesian Naqshbandīs began visualizing Indonesian masters in the rābita. ${ }^{56}$ 


\section{SUFI ORDERS, PESANTREN TAREKAT, AND PUTIHAN VILLAGE COMMUNITIES}

Babussalam is a unique case because of the scale of 'Abdul Wahab's successes in spreading the tarīqa and organizing agricultural production, but there were other cases of tarīqa teachers establishing village communities in the twentieth century. Such examples of institutionalizing tarekat highlight the transformations undergone by Sufi orders within the Indonesian archipelago during the nineteenth and twentieth centuries. A century before 'Abdul Wahab, the Banjarese scholar Arshad al-Banjārī (d. 1812) — who had spent many years studying in Arabia and was probably affiliated with the Sammāniyya-similarly built a new village on a tract of wasteland granted to him by the sultan of Banjarmasin, which went on to become the major center of Islamic education in South Borneo. Arshad al-Banjārī together with his family and followers dug irrigation canals and opened up the land for cultivation, making the village a model for agricultural development in the region. ${ }^{57}$ In 'Abdul Wahab's time, other khaliffa of Sulaymān al-Zuhdī opened up their own villages in the forested interior of Java and Sumatra, and many more took up teaching the Naqshbandi devotions in existing mosques and pesantren. ${ }^{58}$ Many of these khalif $a$ appointed their own deputies and established expanding networks of local groups of Naqshbandī affiliates. Two generations later, we find Naqshbandī shaykhs leading Sufi villages similar to Babussalam in South Aceh and Malaya. ${ }^{59}$

The rapid expansion of the Naqshbandiyya Khālidiyya was in part due to the reforms Mawlānā Khālid (d. 1827) had introduced into the order, the large number of khalif $a$ he appointed, and the missionary zeal he inspired in them. Its expansion in the Ottoman Empire preceded that in Indonesia and was even more rapid and spectacular. Shaykh Khālid had well over sixty khalīfa, in different parts of the Ottoman Empire, several of whom appointed numerous khalifa of their own (although none may have been as prolific in this respect as 'Abdul Wahab Rokan). Whereas in the Ottoman domains the Naqshbandiyya Khālidiyya was the only order that showed such dynamism in the nineteenth century, in Indonesia its expansion and activities had much in common with those of the two other recently arriving orders, the Sammāniyya and the Qādiriyya wa'l-Naqshbandiyya, which also had a number of regional networks with an internal hierarchy in Indonesia and a central authority based in Mekka or Medina.

The expansion of these centralized tarīqa networks in the nineteenth century was part of a broader development, the proliferation of rural (and occasionally urban) communities that signaled their stronger commitment and stricter adherence to Islam by wearing white headgear or dress, thus distinguishing themselves from their surroundings. There were various types of such communities, known in Java as putihan or pamutihan ("white ones"). Some consisted of families that guarded holy graves and could boast a long history; others had 
emerged more recently around a religious teacher or a village head of exemplary piety. Some, but not all, of these communities were exempted from certain taxes and other obligations in exchange for the religious services they provided for local rulers. Many pesantren found their origin in such putihan communities. The increase in the number of these communities was largely due to the increasing numbers of men returning from studies in Mekka and setting themselves up as teachers. ${ }^{60}$

Not all founders of pesantren and/or putihan communities had a Mekkan connection, however. One of the oldest extant pesantren of West Java is that of Buntet in Cirebon, founded in the late eighteenth century. The teachers, their families, and adherents there came to constitute a large putihan community. As oral tradition has it, before becoming a center of textual learning, Buntet was a pesantren tarekat, where adults came in search of supernatural power. The tarīqa that was taught here was the Shațāriyya, the same as that of the Cirebon court, but Buntet's first Shattārī teacher, known as Ki Buyut Kriyan, had taken his $i j a \bar{z} a$ neither from court circles nor directly from Medina but from a Javanese teacher in Central Java, Kyai Ash 'arī of Kaliwungu (who had studied in Mekka but is not locally remembered as a tarīqa teacher, but rather as a representative of "Mataram Islam"- the Javanese-Islamic synthesis). ${ }^{61}$ Unlike Babussalam, Buntet was not embedded in a larger tariqqa network, but the community appears to have carried out Shattārī devotions collectively. It was a putihan community not directly connected with Mekka but inspired by tarekat teachings embedded in Javanese culture. In the early twentieth century, however, facing competition from a nearby Qādiriyya wa'l-Naqshbandiyya pesantren, Buntet was the first in Indonesia to adopt and actively propagate the Tījāniyya tarīqa, in which one of the teachers, Kiai Anas, had been initiated during a stay in Arabia. This new development made the pesantren the center of a highly dynamic network of adepts and mobilized devotees recognizing a higher authority in Medina. ${ }^{62}$

These putihan communities and the pesantren that gained prominence in the nineteenth century constituted orderlike social formations that might be, but in many cases were not, affiliated with a regular tariqa and connected to an external source of religious authority. Little detailed information on the putihan communities is available. Colonial surveys of perdikan (tax-exempted) villages were compiled relatively late and moreover probably missed newly founded putihan villages that did not have old tax privileges. The Javanese santri lelana literature (Serat Centhini, Serat Jatiswara, and so on) makes frequent mention of such communities but provides little concrete information, and local histories may give valuable information but are notoriously vague about chronology. There are, nonetheless, some indications that over the course of the "long" nineteenth century (beginning in the late eighteenth and continuing into the twentieth) the number of putihan communities significantly increased, and there was a significant shift of orientation. Although previously most of these communities had been connected with local centers of spiritual power such as holy 
graves, they increasingly came to be connected, via silsila and/or isnād, with authorities in Mekka or Medina.

Both the tariqga and the pesantren were associated with putihan communities, but there was no simple or uniform relationship between these different social categories in nineteenth-century Java. Most putihan communities mentioned in Javanese texts performed various types of communal and individual devotions besides the obligatory prayers but may not have adhered to any specific tarīqa. Conversely, not all țariqa followers belonged to putihan communities, even if most teachers did. The Shatțāriyya was present in this period as a diffuse influence. Popular beliefs and magical practices were influenced by cosmological and metaphysical ideas once associated with this tarīqa. Most Shatțārī teachers were a few generations removed from the last representatives of the learned line of teachers in Medina, and there appeared to be little uniformity in what they taught. The Qādiriyya wa'l-Naqshbandiyya and the Naqshbandiyya Khālidiyya (and later the Tījāniyya) were more centralized orders. Communities of followers were connected with one another and especially with the central authority in Mekka. Both orders also, at least in theory, demanded strict adherence to the sharī'a and therefore some degree of textual knowledge.

The simplest pesantren only taught the Arabic script and memorization of some passages from the Qur'ān, although some also taught basic fiqh and doctrine, using simple textbooks. As the nineteenth century progressed, more pesantren emerged that also taught more sophisticated figh books and other $k i t a \bar{b}$ in Arabic. Their founders were typically men who had spent years in Mekka in the teaching circles of established scholars, in most cases resident Jāwa ' ulamā' reading these kitāb under supervision and finally receiving ijāza to teach them. These men's relationship with their Mekkan teachers differed little from that of an Indonesian khalīfa of a tarīqa with his shaykh. In fact, although a scholar did not expect the same level of submission and obedience that the tariqa shaykh demanded, the bond with him could even be stronger because of the protracted and intensive interaction that went with textual studies. ${ }^{63}$ The isnäd constituted a lasting link of authority and legitimation, like the silsila, the main difference being that most graduates from Mekka had multiple isnād, connecting them with more than one Mekkan teacher. Having studied under the same teachers in Mekka created bonds among the Javanese Islamic teachers (kyai) similar to those between adepts of the same tariqa. Jointly, the community of Jāwa scholars resident in Mekka and their students who established (or taught at) pesantren in Southeast Asia constituted a sort of brotherhood, membership in which was not dependent on a formal bay'a but on the ijāza proving the successful mastery of a body of texts.

By the mid-nineteenth century, this brotherhood of kitāb scholars and their students probably made up only a minor, but growing, proportion of all those classified by the Dutch as geestelijken ("clerics" who made their living by religion). ${ }^{64}$ Many of the latter simply provided religious services such as leading 
salāt prayers or other devotions, taking care of the dead, guarding holy graves and overseeing grave visitation, reciting supplications $\left(d u^{\prime} \bar{a}^{\prime}\right)$ on behalf of clients, divination, and healing. Many also taught $d h i k r$, wird, and various other formulae to be recited for magical purposes. Indeed the word tarekat was widely used to refer to magical practices even when there was no formal initiation into a specific tarīqa. The most significant shift taking place in the nineteenth century is that the two types of Mekka-based "orders," the new Sufi tarekat and the brotherhood of kitāb scholars, gradually became dominant in influence, if not in numbers, within the category of religious specialists.

To summarize, a tarīqa can be defined by three aspects. Each has, first, a distinct spiritual genealogy, or silsila, and, second, a repertoire of techniques and devotions that constitute its distinct "way." In addition, they can be associated with a specific pattern of social organization in which particular institutions may be diversely configured. Regarding the third aspect, a single tariqqa may show great variety over time and space.

The spiritual techniques of various established Sufi tarīqa have been taught in Southeast Asia since the seventeenth century and quite possibly since the second half of the sixteenth. Sufi thought and practice initially circulated primarily among the aristocratic elite of the indigenous sultanates. A lively interest in Sufi metaphysics and debates about the interpretation of the doctrine of wahdat al-wujüd appears to have preceded the adoption of tariqa as standardized ways of attaining the mystical experience. Actual adherence to a tariqa long remained restricted, but at least in some regions certain practices of recitation (dhikr, wird, rātib) became part of popular devotion. The social organization of the tariqa remains the most elusive aspect. The extant sources suggest that tarīqa teachers had but few khalīfa and that the numbers actually inducted into a tariq a remained restricted.

Only from the nineteenth century onwards do we find reports of large numbers of people publicly taking part in collective tarīqa rituals. Besides greater concern on the part of Dutch colonial officials who cared to report on these activities, this may reflect two important changes in the relations between Southeast Asian Muslims and the symbolic center of the Muslim world - the holy cities of Mekka and Medina. Larger numbers of Southeast Asians were spending many years studying in the holy cities, which had become easier because the number of "Jāwa" scholars resident there who could serve as teachers for an increasing number of students from Southeast Asia had reached a critical mass. Moreover, new țarīqa had emerged that actively recruited among the Jāwa pilgrims and students, using the Malay language as a medium: the Sammāniyya in the eighteenth, and the Qādiriyya wa'1-Naqshbandiyya and Naqshbandiyya Khālidiyya in the nineteenth century. The khalifa of these orders established rapidly expanding networks of local adepts and affiliates, turning the tarīqa into mass movements no longer associated with elite court culture. 
There was during this same period a similar, albeit slower, expansion of schools where Islamic texts (kitāb) were taught. Mekka-trained scholars, united by common loyalty to the teachers to whom they owed their ijäza, constituted a sort of brotherhood that stood out among the class of professional religious and by the early twentieth century had become dominant among them. Scholars and pesantren teaching kitāb thus constituted parallel and potentially overlapping networks that were structurally similar to those of the new Sufi orders - as seen in the documentation of religious lineages in the parallel forms of silsila and $i s n \bar{a} d$. For both, Mekka was the exemplary center where ultimate authority was located and where each new generation sought spiritual and scholarly perfection. Both also had secondary centers in different parts of Southeast Asia from which further expansion took place. The Saudi conquest of Mekka in 1924 was to result in changes in these networks again, notably a renewed indigenization of the tariqa networks, but those developments are beyond the scope of this chapter.

\section{NOTES}

1. Russell Jones, "Ten Conversion Myths from Indonesia," in Conversion to Islam, edited by Nehemia Levtzion (New York: Holmes and Meier, 1979), pp. 129-158. One should not forget, however, that these myths are of much later date than the alleged conversion event.

2. G. W. J. Drewes, Een Javaanse primbon uit de zestiende eeuw (Leiden: Brill, 1954); G. W. J. Drewes, The Admonitions of Seh Bari (The Hague: Nijhoff, 1969).

3. The first mission was sent in 1638. Several later rulers sent similar missions upon accession. The metaphysical questions seem to refer to works written by Hamza and another, unknown author. Titik Pudjiastuti, "Sadjarah Banten: suntingan teks dan terjemahan disertai tinjauan aksara dan amanat" (Ph.D. diss., Universitas Indonesia, Depok, 2000), canto 37.7, 42.26; see also Hoesein Djajadiningrat, Critische beschouwing van de Sadjarah Banten: Bijdrage ter enschetsing van de Javaansche geschiedschrijving (Haarlem: Joh. Enschedé en Zonen, 1913), pp. 50, 174-175.

4. Anthony H. Johns, "The Role of Sufism in the Spread of Islam to Malaya and Indonesia," Journal of the Pakistan Historical Society 9 (1961): 143-160; Anthony H. Johns, "Sufism as a Category in Indonesian Literature and History," Journal of Southeast Asian History 2 (1961): 10-23.

5. Claude Guillot and Ludvik Kalus, "La stèle funéraire de Hamzah Fansuri," Archipel 60 (2000): 3-24; Claude Guillot and Ludvik Kalus, "En réponse à Vladimir I. Braginsky," Archipel 62 (2001): 34-38.

6. It has been claimed, on the basis of one of Hamza's quatrains, in which he declares that he received trusteeship of the exalted knowledge (beroleh khilafat ilmu yang 'ali) from'Abd al-Qādir al-Jīlānī, that he belonged to the Qādiriyya Sufi order and was in fact a khalīfa, a deputy representing the grand shaykh himself. Syed Muhammad Naguib Al-Attas, The Mysticism of Hamzah Fansuri (Kuala Lumpur: University of Malaya Press, 1970), pp. 10-11. This is one possible reading, and there are a few more references to 'Abd al-Qādir in Hamza's works that indicate that he felt a special veneration for the Baghdadi saint. However, although there are frequent later references to Hamza's poetry and Sufi metaphysics, his name is never 
mentioned in later chains of transmission of the Qādiriyya in Indonesia. For this and other reasons, I believe his teaching in Aceh did not include formal instruction in the taríqa. For more on this, see the arguments presented in Martin van Bruinessen, "Shaykh 'Abd al-Qâdir al-Jîlânî and the Qâdiriyya in Indonesia," Journal of the History of Sufism 1-2 (2000): 361-395, esp. pp. 362-364.

7. See Rānīrî̀s silsila as given in his Jawāhir al-'ulūm fi kafsh al-ma' lüm, in Syed Naguib Al-Attas, A Commentary on the Hujjat al-siddīq of Nūr al-Dìn al-Rānīrī (Kuala Lumpur: Ministry of Culture Malaysia, 1986), pp. 14-15. On Bā Shaybān and Rān̄̄rī’s other teachers, see Azyumardi Azra, The Origins of Islamic Reform in Southeast Asia: Networks of MalayIndonesian and Middle Eastern 'Ulamä' in the Seventeenth and Eighteenth Centuries (Leiden: KITLV Press, 2004), pp. 54-62.

8. Yūsuf gives the silsila of various țarīqa in his as yet unpublished Safīnat al-najāh. These silsila are reproduced in Abu Hamid, Syekh Yusuf Makassar: Seorang ulama, sufi dan pejuang (Jakarta: Yayasan Obor Indonesia, 1994), pp. 356-363. On Muḥammad Jīlānī Rānīrī and his Sufi teaching, see Azra, Origins of Islamic Reform, pp. 55-56.

9. Martin van Bruinessen, "The Tariqa Khalwatiyya in South Celebes," in Excursies in Celebes, edited by Harry A. Poeze and Pim Schoorl (Leiden: KITLV, 1991), pp. 251-269; Martin van Bruinessen, "Shari a Court, Tarekat and Pesantren: Religious Institutions in the Banten Sultanate," Archipel 50 (1995): 165-199, esp. pp. 180-182.

10. Martin van Bruinessen, "Najmuddin al-Kubra, Jumadil Kubra and Jamaluddin alAkbar: Traces of Kubrawiyya Influence in Early Indonesian Islam," Bijdragen tot de Taal-, Land- en Volkenkunde 150 (1994): 305-329, esp. pp. 307-313, referring to the texts edited by Edel. See also J. Edel, Hikajat Hasanoeddin (Meppel: Brink, 1938). The Cirebon court chronicle Babad Cerbon also mentions Sunan Gunung Jati's studying the Shādhiliyya, Kubrawiyya, and Khalwatiyya in Mekka. See J. L. A. Brandes and D. A. Rinkes, eds., Babad Tjerbon (Batavia: Albrecht \& Co.; The Hague: M. Nijhoff, 1911), pp. 66-67.

11. J. Spencer Trimingham, The Sufi Orders in Islam (Oxford: Clarendon Press, 1971), p. 103, summarizing the preceding historical discussion. Later scholars have been critical of some of Trimingham's analyses and claims, and there exists now a vast body of detailed and more sophisticated scholarship, but this remains the major synthesizing study. Two more recent major overviews are Alexandre Popovic and Gilles Veinstein, eds., Les voies d'Allah: Les ordres mystiques dans le monde musulman des origines à aujourd'hui (Paris: Fayard, 1996); Seyyed Hossein Nasr, ed., Islamic Spirituality: Manifestations (New York: Crossroad, 1991), both of which are rich in information about individual orders but do not attempt an overall synthesis.

12. Various aspects of the Sufi lodge are discussed in R. Lifchez, ed., The Dervish Lodge: Architecture, Art, and Sufism in Ottoman Turkey (Berkeley: University of California Press, 1992). For a description of different types of lodges in a single Sufi order in contemporary Egypt, the Khalwatiyya, see Rachida Chih, "What Is a Sufi Order? Revisiting the Concept through a Case Study of the Khalwatiyya in Contemporary Egypt," in Sufism and the "Modern" in Islam, edited by Martin van Bruinessen and Julia D. Howell (London: I. B. Tauris, 2007), pp. 21-38.

13. In his study of Sufism in Egypt and Syria in the Mamluk period, Eric Geoffroy suggests that the khānaqa was an institution defined by its powerful or rich founder, and the zāwiya was known for the Sufi master who led it. Eric Geoffroy, Le soufisme en Égypte et en Syrie sous les derniers Mamelouks et les premiers Ottomans: Orientations spirituelles et enjeux culturels 
(Damascus: Institut français de Damas, 1995), pp. 116-175. Geoffroy's distinction may be valid for that period, but I do not believe it makes sense for other times and places.

14. This process is analyzed for the case of the Naqshbandiyya at a period of rapid expansion in nineteenth-century Kurdistan in Martin van Bruinessen, Agha, Shaikh and State: The Social and Political Structures of Kurdistan (London: Zed Books, 1992), pp. 224-228.

15. For Syria and Egypt, see Geoffroy, Soufisme en Égypte et en Syrie, which provides a detailed overview of the varieties of Sufi practice, institutions, and forms of association in the fourteenth and fifteenth centuries. For Asia Minor, important insights on the nature of Sufi and dervish groups of the same period are presented by Ahmet T. Karamustafa, God's Unruly Friends: Dervish Groups in the Islamic Later Middle Period, 1200-1550 (Salt Lake City: University of Utah Press, 1994); and Mustafa Kara, Türk tasavvuf tarihi araştırmaları: Tarikatlar-tekkeler-şeyhler (Istanbul: Dergah, 2005). For South Asia, see Saiyid Athar Abbas Rizvi, A History of Sufism in India, vol. 1: Early Sufism and Its History in India to 1600 $A D$ (New Delhi: Munshiram Manoharlal, 1978). On the expansion of the Naqshbandiyya from Central Asia to the west and south, Hamid Algar, "The Naqshbandi Order: A Preliminary Survey of Its History and Significance," Studia Islamica 44 (1976): 123-152; Dina Le Gall, A Culture of Sufism: Naqshbandîs in the Ottoman World, 1540-1700 (Albany, NY: State University of New York Press, 2005); Saiyid Athar Abbas Rizvi, A History of Sufism in India, vol. 2: From Sixteenth Century to Modern Century (New Delhi: Munshiram Manoharlal, 1983).

16. Trimingham rightly observes that the term $t \vec{a}$ if $a$ was also used for two other types of associations with a religious character that should be distinguished from the Sufi order although having similar patterns of organization: the trade guild and the futuwwa ("youngmanliness," or chivalry) association. The Kāzarūniyya, of which we know thanks to the early fourteenthcentury Moroccan traveler Ibn Bațtuța, was yet another similar formation. Rizvi, History of Sufism in India, vol. 1, pp. 409-411, discusses it as a special type of Sufi order. Trimingham, Sufi Orders in Islam, p. 21, calls it a "Sufi insurance company." It consisted of a network of lodges dedicated to the eleventh-century Sufi Abū Ishāa Kāzarūnī, patron saint and protector of sailors and merchants along the trade routes between the Persian Gulf and South China. Ibn Bațtuțta visited the saint's shrine in Kāzarūn (Southern Iran) and the khānaqā in Cambay and Calicut in India, as well as the one outside the major South Chinese port of Zaytun, and notes that merchants vowed sums of money to the saint in exchange for protection. These sums were collected by the guardians of the various khānaq $\bar{a}$ (whose names were appended with the nisba Kāzarūn̄̄, suggesting they were either biological descendants of Abū Ishaq or licensed representatives, khali $f a$ ) on behalf of the central shrine and redistributed according to an intricate system that Ibn Bațțūta describes. There is, however, no mention of Sufi rituals or local followers of these khaliffa. They appear as agents of a financial institution rather than spiritual teachers. (See the summary of the functioning of this commercialization of Abu Ishaq's baraka in Trimingham, Sufi Orders in Islam, p. 236.)

17. Bruinessen, "Tarīqa Khalwatiyya in South Celebes," pp. 255-256, after Yūsuf's Habl al-warìd li-sa'ädat al-murìd. Cf. Abu Hamid, Syekh Yusuf Makassar, pp. 206-210.

18. D. A. Rinkes, "Abdoerraoef van Singkel: Bijdrage tot de kennis van de mystiek op Sumatra en Java" (dissertation, Leiden, 1909), pp. 64-75 (after 'Abd al-Ra'ūf's 'Umdat al-muhtājīn); Oman Fathurahman, Tanbih al-masyi: menyoal wahdatul wujud: Kasus 'Abdurrauf Singkel di Aceh abad 17 (Bandung: Mizan, 1999), pp. 66-74 (after Tanbīh al-māshī). 
19. Rinkes, "Abdoerraoef van Singkel," pp. 74-75.

20. Rätib performances in late nineteenth-century Aceh are described in great detail in Christiaan Snouck Hurgronje, De Atjèhers, vol. 2 (Batavia: Landsdrukkerij; Leiden: Brill, 1893), pp. 220-265.

21. "The mysticism of the Shațāriyya reveals itself only in the observation of certain unspectacular, simple private recitations." Snouck Hurgronje, De Atjèhers, vol. 2, p. 221.

22. Ibid., pp. 16-20.

23. Ph. S. van Ronkel, "Het heiligdom te Oelakan," Tijdschrift voor Indische Taal-, Land-en Volkenkunde 56 (1914): 281-316; Azra, Origins of Islamic Reform, pp. 84-86; Oman Fathurahman, Tarekat Syattariyah di Minangkabau, teks dan konteks (Jakarta: Prenada Media Group/EFEO/PPIM/KITLV Jakarta, 2008), pp. 34-40; Rinkes, "Abdoerraoef van Singkel"; Tommy Christomy, "Shattâriyya Tradition in West Java: The Case of Pamijahan," Studia Islamika 8.2 (2001): 55-82. Azra and Fathurahman mention a few other alleged students of 'Abd al-Ra'üf, but there is no evidence that these also came to represent the Shațāriyya.

24. Rinkes, "Abdoerraoef van Singkel," pp. 94-130; Aliefya M. Santrie, "Martabat (Alam) Tujuh: Suatu naskah mistik Islam dari desa Karang, Pamijahan," in Warisan intelektual Islam Indonesia: Telaah atas karya-karya klasik, edited by Ahmad Rifa i Hasan (Bandung: Mizan, 1987), pp. 105-129; Tommy Christomy, "Signs of the Wali: Narratives at the Sacred Sites in Pamijahan, West Java" (Ph.D. diss., Australian National University, 2003 [published as an e-book by ANU Press in 2008]), pp. 25-37; Fathurahman, Tarekat Syattariyah di Minangkabau, pp. $72-100$.

25. Sharon Siddique, "Relics of the Past. A Sociological Study of the Sultanates of Cirebon, West Java" (Ph.D. diss., Bielefeld University, 1977), pp. 122-124; A. G. Muhaimin, "The Islamic Traditions of Cirebon: Ibadat and Adat among Javanese Muslims" (Ph.D. diss., Australian National University, 1995 [published as an e-book by ANU Press in 2006]), pp. 247-251. My interviews with pesantren- and court-based Shațāāī teachers in Cirebon suggest that there was a considerable difference in practice between these two milieus.

26. Bruinessen, "Shari a Court, Tarekat and Pesantren," p. 182.

27. See note 3 above.

28. Oman Fathurahman, "Ithăf al-dhakī by Ibrāhīm al-Kūrānī: A Commentary of wahdat al-wujūd for Jawi Audiences," Archipel 81 (2011): 177-198; Anthony H. Johns, "Friends in Grace: Ibrāhīm al-Kūrānī and 'Abd al- Ra'ūf al-Singkeli," in Spectrum: Essays Presented to Sutan Takdir Alisjahbana, edited by S. Udin (Jakarta: Dian Rakyat, 1978), pp. 469-485. On Fadlullah Burhānpūri's Al-Tuhfa al-mursala ila rūh al-nabī and its Javanese and Malay adaptations, see Anthony H. Johns, The Gift Addressed to the Spirit of the Prophet (Canberra: Australian National University, 1965).

29. Snouck Hurgronje, De Atjèhers, vol. 2, p. 262.

30. The entire text of the syair is published in M. O. Woelders, Het sultanaat Palembang 1811-1825 ('s-Gravenhage: Nijhoff, 1975), pp. 194-222 (Dutch translation at pp. 385-413).

31. P. J. Veth, "Het beratip beamal in Bandjermasin," Tijdschrift voor Nederlandsch-Indië 3.2 (1869-1870): 197-202; Helius Sjamsuddin, "Islam and Resistance in South and Central Kalimantan in the Nineteenth and Early Twentieth centuries," in Islam in the Indonesian Social Context, edited by M. C. Ricklefs (Clayton: Monash University Centre of Southeast Asian Studies, 1991), pp. 7-17. The rātib reported there was not the standard Sammānī rātib, but diverging versions have been reported from elsewhere too. The Sammāniyya is known to have been introduced into this region by Nafīs al-Banjārī, the author of the locally popular Sufi treatise al-Durr al-nafīs, and possibly by other returnees from Arabia as well. 
32. In calling these synthetic orders "new," I refer to their recent emergence as distinct formations and am not alluding to "Neo-Sufism," a term that has been used to refer to too many different things and has so far caused more confusion than clarity (see the discussion in Martin van Bruinessen, "Sufism, 'Popular' Islam, and the Encounter with Modernity," in Islam and Modernity: Key Issues and Debates, edited by Muhammad Khalid Masud, Armando Salvatore, and Martin van Bruinessen [Edinburgh: Edinburgh University Press, 2009], pp. 125-157).

33. For an example of such a dhikr, see Syed Naguib Al-Attas, Some Aspects of Sufism as Understood and Practised among the Malays (Singapore: Malaysian Sociological Research Institute, 1963), p. 86.

34. On 'Abd al-Samad and his networks, see Azra, Origins of Islamic Reform, pp. 111-117; Martin van Bruinessen, "Studi tasawuf pada akhir abad kedelapan belas: 'Abd al-Ṣamad alFalimbani, Nafis al-Banjari, dan tarekat Sammaniyah," in Bruinessen, Kitab kuning, pesantren dan tarekat: Tradisi-tradisi Islam di Indonesia (Bandung: Mizan, 1995), pp. 55-87.

35. Aḥmad Purwadaksi, "Rātib Sammān dan Hikayat Syekh Muhammad Sammān. Suntingan naskah dan kajian isi teks" (Ph.D. diss., Universitas Indonesia, Jakarta, 1992), pp. 335-336.

36. Bruinessen, "Tariqa Khalwatiyya in South Celebes," pp. 258-262; Bruinessen, "Studi tasawuf pada akhir abad kedelapan belas"; G. W. J. Drewes, "A Note on Muhammad al-Sammān, His Writings, and 19th Century Sammāniyya Practices, Chiefly in Batavia, according to Written Data," Archipel 43 (1992): 73-87. Other well-known 'ulamä' affiliated with the Sammāniyya include M. Arshad al-Banjārī, Nafīs al-Banjārī, and Daūd al-Fațānī (Patani). Besides Southeast Asia, the order spread only to Sudan and is virtually unknown elsewhere. On the Sammāniyya's development in Sudan, see Ali Salih Karrar, The Sufi Brotherhoods in the Sudan (London: C. Hurst and Company, 1992), pp. 43-49.

37. On the rātib: Purwadaksi, "Rātib Sammān dan Hikayat Syekh Muḥammad Sammān"; Al-Attas, Some Aspects of Sufism, pp. 68-88; Snouck Hurgronje, De Atjèhers, vol. 2, pp. 220 265; Veth, "Het beratip beamal in Bandjermasin."

38. In this case these were, as the earliest handbook of the order, Fath al-ärifin, has it, the Naqshbandiyya, Qādiriyya, Țarīqat al-Anfās, Țarīqat al-Junayd, and Ṭarīqat al-Muwāfaqa. The same text makes the intriguing observation that this combination of tarīqa is identical (?) with the Sammāniya. A similar synthetic order with which Aḥmad Khațīb may have been well acquainted was the Khatmiyya, which became important in Sudan (see Karrar, Sufi Brotherhoods in the Sudan, pp. 64-66, 73-102).

39. Sartono Kartodirdjo, The Peasants' Revolt of Banten in 1888 ('s-Gravenhage: Nijhoff, 1966); Sartono Kartodirdjo, Protest Movements in Rural Java (Kuala Lumpur: Oxford University Press, 1973); Christiaan Snouck Hurgronje, "Mystiek, magie, tarékats," in Ambtelijke adviezen van C. Snouck Hurgronje, 1889-1936, vol. 2, edited by E. Gobée and C. Adriaanse ('s-Gravenhage: Nijhoff, 1959), pp. 1182-1221; Bruinessen, "Shaykh 'Abd alQâdir," pp. 378-381.

40. Sri Mulyati, Peran edukasi tarekat Qadiriyyah Naqsyabandiyyah dengan referensi utama Suryalaya (Jakarta: Kencana, 2010); Bruinessen. "Shaykh 'Abd al-Qâdir," pp. 382-386.

41. This expansion had begun in a much earlier period. The reason Yūsuf of Makassar did not settle in his native Gowa on his return from Arabia but opted to live in Banten was that Gowa had been conquered by its Bugis neighbor Bone and the Netherlands East Indies Company. When the company later intervened in Banten too, replacing Sultan Ageng Tirtayasa with his more pliant son, Sultan Haji, Yūsuf firmly sided with the former and took to the mountains. Company troops captured him, and he was sent into exile in Ceylon. 
42. Martin van Bruinessen, "Pesantren and Kitab Kuning: Continuity and Change in a Tradition of Religious Learning," in Texts from the Islands: Oral and Written Traditions of Indonesia and the Malay World, edited by Wolfgang Marschall (Berne: University of Berne Institute of Ethnology, 1994), pp. 121-146; M. C. Ricklefs, Polarising Javanese Society: Islamic and Other Visions (c. 1830-1930) (Singapore: NUS Press, 2007), pp. 49-74.

43. Several of the pesantren I have visited retain memories of previously having been pesantren tarekat, which meant they did not teach bookish knowledge but spiritual techniques, often for magical purposes.

44. This Jāwa community was famously described in the second volume of Snouck Hurgronje's Mekka (The Hague: Martinus Nijhoff, 1889).

45. Two famous examples are Aḥmad Qushāshī's Al-Simt al-majīd and Ibrāhīm Kūrānī's Al-Umam li-iqāa al-himam, both of which were printed in Hyderabad as recently as $1909-1910$.

46. Shaykh Yāsīn was the director of the Indonesian college Dār al-'Ulūm al-Islāmiyya in Mekka. He wrote at least ten such books, of which the most important are M. Yāsīn b. M. 'Īsā al-Fadān̄̄, Al-'iqd al-farīd min jawāhir al-asānīd (Surabaya: Dār al-Saqqāf, n.d.), and idem, Nayl al-amān̄̄ fì ba' d asānīd al-shaykh Muhammad Yāsīn bin Muhammad 'Īsā al-Fadān̄̄ (Jakarta: Panitia Haul Syekh Moh. Yasin Isa al-Fadani, 1993).

47. Snouck Hurgronje, Mekka, vol. 2, p. 372. Snouck observes that both Aḥmad Khațīb and his successor 'Abd Karīm Banten enjoyed the respect of all social classes, including even the most learned scholars, primarily the Jāwa but also scholars of local origin. He also makes some interesting observations on 'Abd al-Karīm's teaching of the tarīqa and relations with different categories of affiliates; ibid. 372-379.

48. Snouck Hurgronje, Mekka, vol. 2, pp. 285-287, 380-381, 389 (on the Naqshbandi shaykhs), 355 (on Ismā̄îl Minangkabawī).

49. Martin van Bruinessen, Tarekat Naqsyabandiyah di Indonesia: Survei historis, geografis, dan sosiologis (Bandung: Mizan, 1992), chaps. 7, 10-12; Martin van Bruinessen, "After the Days of Abû Qubays: Indonesian Transformations of the Naqshbandiyya-Khâlidiyya," Journal of the History of Sufism 5 (2008): 225-228; Werner Kraus, "Some Notes on the Introduction of the Naqshbandiyya-Khālidiyya into Indonesia," in Naqshbandis: Cheminements et situation actuelle d'un ordre mystique musulman, edited by Marc Gaborieau, Alexandre Popovic, and Thierry Zarcone (Istanbul and Paris: Éditions Isis, 1990), pp. 691-706.

50. These khalïfa are listed, district by district, in H. A. Fuad Said, Syekh Abdul Wahab: Tuan guru Babussalam (Medan: Pustaka Babussalam, 1983), pp. 136-139; for wives and descendants, see pp. 170-185. The author of this biography/hagiography is one of 'Abdul Wahab's 207 grandchildren.

51. Description of life in Babussalam after Said's volume and my own interviews in the village in November 1993. See also Denys Lombard, "Tarekat et entreprise à Sumatra: L'exemple de Syekh 'Abdul Wahab Rokan (c. 1830-1926)," in Naqshbandis, edited by Gaborieau, Popovic, and Zarcone, pp. 707-715.

52. According to the biography, 'Abdul Wahab sent al-Zuhdī each year at least 400 ringgit, the equivalent of 1,000 Dutch guilders. See Said, Syekh 'Abdul Wahab, p. 40.

53. Said, Syekh 'Abdul Wahab, pp. 57-58.

54. See Butrus Abu-Manneh, "Khalwa and Rabita in the Khalidi Suborder," in Naqshbandis, edited by Gaborieau, Popovic, and Zarcone, pp. 283-302, on Mawlānā Khālid's emphasis on khalwa as a physical retreat from the world. This differed from the classical Naqshbandī principle of khalwat dar anjuman, the cultivation of an otherworldly attitude while 
actively engaging with the world. Of the other orders, most branches of the Khalwatiyya (which owes its name to the practice) are said to have endorsed khalwa, but there is no unambiguous indication that it was ever introduced into Indonesia. (There is one intriguing account by the French missionary Nicolas Gervaise of what could be khalwa in a mosque in Makassar in the $1680 \mathrm{~s}$, but Gervaise had not been there himself and his description seems colored by his personal acquaintance with Thai Buddhism; see Christian Pelras, "La première description de Célèbes-sud en français et la destinée remarquable de deux jeunes princes makassar dans la France de Louis XIV," Archipel 54 [1997], pp. 63-80, esp. p. 67; Michael F. Laffan, The Makings of Indonesian Islam: Orientalism and the Narration of a Sufi Past [Princeton University Press, 2011], pp. 20-21.)

55. Snouck Hurgronje, "Mystiek, magie, tarékats," pp. 1182-1183. On the importance of the rābita in the Khālidiyya branch of the Naqshbandiyya, see Abu-Manneh, "Khalwa and Rabita in the Khalidi Suborder."

56. See also: Bruinessen, "After the Days of Abû Qubays."

57. Karel A. Steenbrink, Beberapa aspek tentang Islam di Indonesia abad ke-19 (Jakarta: Bulan Bintang, 1984), p. 94; Azra, Origins of Islamic Reform, pp. 119-120.

58. Bruinessen, Tarekat Naqsyabandiyah di Indonesia, pp. 125-128 (West Sumatra), 162167 (Girikusumo and Sokaraja in Java), and 162-172.

59. Ibid., pp. 143-146 (South Aceh), 158-160 (Selangor, Malaysia).

60. Insightful observations on the various types of putihan villages can be found in Christiaan Snouck Hurgronje, "Vrije desa's," in Ambtelijke adviezen van C. Snouck Hurgronje, 1889-1936, edited by E. Gobée and C. Adriaanse, vol. 1 ('s-Gravenhage: Nijhoff, 1957), pp. 722-735 (written in 1895), which supersedes older Dutch studies. A putihan lineage guarding holy graves in the Surakarta region is discussed in Stephen C. Headley, "The Islamization of Central Java: The Role of Muslim Lineages in Kalioso," Studia Islamika 4.2 (1997): 55-82. On putihan villages and pesantren, see Bruinessen, "Pesantren and Kitab Kuning." On the hajj and the proliferation of putihan communities, see Ricklefs, Polarising Javanese Society, pp. 49-74.

61. Muhaimin, "Islamic Traditions of Cirebon," pp. 249-250, and personal interviews in Buntet; the silsila names a Muhammad Sa î̉ Madanī as Ash 'arī’s teacher and continues through "Tāhir Madanī," "Ibrāhīm," and another "Tāhir" to Ibrāhīm al-Kūrānī (various combinations of the same name, sometimes as Ibrāhīm b. Tāhir or Tāhir b. Ibrāhīm, occur in other Javanese Shattārī silsila). Local memories of Kyai Ash 'arī are compiled in Sholekhatul Amaliyah, "Peran Kyai Asy'ari (Kyai Guru) dalam berdakwah di Kecamatan Kaliwungu Kabupaten Kendal" (Walisongo State Islamic University thesis, Semarang, 2010).

62. G. F. Pijper, "De opkomst der Tidjaniyyah op Java," in Pijper, Fragmenta Islamica (Leiden: Brill, 1934), pp. 97-121; Martin van Bruinessen, "Controversies and Polemics Involving the Sufi Orders in Twentieth-Century Indonesia," in Islamic Mysticism Contested: Thirteen Centuries of Controversies and Polemics, edited by Frederick de Jong and Bernd Radtke (Leiden: Brill, 1999), pp. 705-728, esp. 720-722.

63. Thus 'Abdul Wahab Rohan retained a lifelong loyalty to his chief teacher of kitāb in Mekka, H. M. Yunus Batu Bara. It had been Yunus who advised him to complement the theoretical study of Sufism through Ghazālī’s $I h y a \overline{~ w i t h ~ p r a c t i c a l ~ e x p e r i e n c e ~ u n d e r ~ S u l a y m a ̄ n ~}$ al-Zuhdī. 'Abdul Wahab later sent annual gifts of money to both, and, when his patron, the sultan of Langkat, visited Mekka, he not only honored al-Zuhdī but showed equal respect to Yunus Batu Bara (Said, Syekh 'Abdul Wahab, pp. 28-33, 58).

64. See the analysis of the statistics on geestelijken, hajjis, schools, and students in the 1860 s through 1880 s, from a variety of Dutch sources, in Ricklefs, Polarising Javanese Society, 
pp. 63-72. Based on the differential geographic distribution of geestelijken and hajjis, Ricklefs gathered that most of the former, who outnumbered the hajjis everywhere but more so in the interior of Java, held religious views similar to the Javanese "mystic synthesis" embraced by the aristocracy, views that were challenged by the new ideas coming from Mekka. He perceives these two types of religious leaders as representing "diverging worlds of pious Islam." My own, slightly different, interpretation is that the divergence took place within the category of geestelijken. Only those hajjis who had pursued serious study in Mekka and on return became teachers made much of an impact. 


\title{
7
}

\section{SHATTTĀRIYYA SUFI SCENTS \\ The Literary World of the Surakarta \\ Palace in Nineteenth-Century Java}

\author{
NANCY K. FLORIDA
}

In February 1815, a poet from the central Javanese palace of Surakarta (Kraton Surakarta) found himself stranded in Aceh on the northern tip of Sumatra. He took the opportunity of this circumstance to render into classical Javanese verse form what he called the "secret" (wadi), "forbidden" (linarangan) teachings of his Sufi masters. The result was a poetic text known as Suluk Acih (Song of Aceh). The poet in question was one Mas Ngabéhi Ronggasasmita, a member of Java's most celebrated literary family. He was grandson to the renowned father of the so-called Surakarta literary renaissance, R. Ng. Yasadipura I (1729-1803), who is sometimes credited for having awakened Javanese literature from the darkness that had putatively covered it since the Muslim conquest of Hindu-Buddhist Java. Ronggasasmita's father was the renowned poet and statesman R. Ng. Yasadipura II (T. Sastranagara, 1756-1844). His brother was R. Ng. Ronggawarsita Sepuh (the Elder Ronggawarsita), the scholar and Muslim "revolutionary" whom the Dutch colonial government exiled to West Sumatra in 1828 for having conspired against them during the Dipanagara War (1825-1830). Manuscript evidence in the palace archive suggests that Ronggasasmita, our stranded poet, shared his brother's fate. The palace manuscript notes that the Elder Ronggawarsita and his younger brother "Mas Haji" were both exiled in punishment for their involvement in the rebellion of Prince Dipanagara. ${ }^{1}$ Ronggasasmita's nephew - the Elder Ronggawarsita's son-was R. Ng. Ronggawarsita (1802-1873), the most celebrated of all Javanese poets. The younger Ronggawarsita, remembered today for his prophetic works, is considered "the last of the court poets" and famed as "the seal of the pujongga."

Ronggasasmita was the author of several important Sufi songs, or suluk. The Arabic word suluk refers to the journey along the mystical path (tariqa or, in the Malay world, tarekat); as a poetic genre in Java, suluk names a corpus of metaphysical texts composed in sung poetry that explore the nature of the 
relationship between God and His creation, especially the relationship between God and humanity. Of special interest in these texts are the nature of the human person (body and soul) and the potential for human perfection in and through God.

Suluk Acih, the suluk composed by our Javanese sojourner in Aceh, forms a compilation of about sixteen or seventeen mystical poems, two of which are "signed" by Ronggasasmita - the 324-line Suluk Acih "proper" and the 340-line Suluk Martabat Sanga (Song of the nine grades of being). ${ }^{3}$ These two poems will form the focus of the present chapter. Ronggasasmita's suluk appears to have been widely disseminated in the middle and later years of the nineteenth century, especially among the Surakartan court elite. Today seventeen manuscript witnesses of the Suluk Acih or portions of it are extant in the three royal archives of Surakarta, that is, the libraries of the Kraton Surakarta, the Pura Mangkunagaran, and the Radya Pustaka Museum. ${ }^{4}$ There are at least fourteen additional witnesses scattered through public and private collections in Indonesia, the Netherlands, and Great Britain. ${ }^{5}$

The poems that make up Suluk Acih concern, among other things, the celestial composition of the human body, the generation (spiritual and corporeal gestation) of each and every human being, the nine levels of Reality manifest in the Prophet Muhammad, the relationship between God and humanity, the nature of creation, the descent from and return to God, the discipline of human perfection, and the discipline of perfect death. The suluk also reveals the movement of a particular Javanese Sufi practitioner through both local and transregional religious networks; it contains brief though fascinating accounts of the author's sojourn in distant Aceh and of his early educational journey through a series of spiritual guides in Java. The text also provides the poet's spiritual genealogy (Ar. silsila; Jv. silsilah). ${ }^{6}$ This genealogy reveals that the secret teachings that Ronggasasmita exposes in his suluk belong to the heritage of the Shațāariyya (Jv. Syattariyah) tarekat. Although tarekat (Ar. tarīqa) is usually translated as "order," in the context of early nineteenth-century Java, the word is better understood as "path," "discipline," or "lineage." The manuscript evidence from that time suggests that the tarekat did not form an "order" in the sense of a corporate body or horizontal brotherhood, but rather that it indicated a tradition of knowledge and practice that was passed vertically from individual masters to their students. In Java, the tarekat only appear to have become congealed into more formalized orders in the later years of the nineteenth century.

The Shattāiriyya forms a Sufi discipline that arose out of the Bistami ecstatic Sufi tradition in fifteenth-century Persia and was brought to Mughal India by Shah 'Abd Allah (Jv. Sèh Ngabdullah Satari) (d. 1485). ${ }^{8}$ Thence it spread to the holy cities of the Hijaz in the sixteenth century, and then on from there to the Malay world in the second half of the seventeenth century. The Shatțāriyya, a minor order in Indonesia today, was the dominant Sufi lineage in the Malay world for nearly two centuries - from the time of its introduction there during 
the 1660 s until the middle of the nineteenth century. ${ }^{9}$ The Shattāaniyya is characterized by the quick speed and relative ease with which its initiates may attain dissolution in God (fana). According to Rizvi, the definitive practices and the emotional and metaphysical frameworks that define the Shațāariyya were set by its sixteenth-century South Asian shaykh, Muhammad Ghawth (Jv. Sèh Muhammad Gos) (d. 1562/3). ${ }^{10}$ Ghawth provided travelers along the mystical path with contemplative practices involving recitations in remembrance of God (zikir; Ar. dhikr) that were performed with bodily discipline, including breath control. All of these were to be practiced under the guidance of a shaykh. ${ }^{11}$

In the Shattāini texts of the premodern Malay world, the traveler would begin his or her journey at the highest level of manifest divinity and from there descend (tanazul) from Divine Perfection through multiple (usually seven) levels of being in order to perform the return (tarki) to God, which she or he would attain on realization of the final and seventh level of being, that of the Perfect Man (insān kāmil). That realization, in both senses of the word, brought to pass the perfection (body and soul) of the traveler's person or self (awak, sarira). ${ }^{12}$ The ultimate goal was not, however, fan $\bar{a}$ (dissolution of the self into the Godhead) but rather the stage called fan $\bar{a}$ ' al-fan $\bar{a}^{\prime}$ (the extinction of the extinction), which would deliver the traveler to the higher station of $b a q \vec{a}$, the ultimate return marked by the self-conscious reintegration of his or her person (body and soul) with the divine. At this stage of the journey, the traveler, experiencing the truth of having always already arrived, would be in a conscious state of everlasting abiding in God, even as he or she, thus empowered, continued to move through life in the phenomenal world.

\section{$\infty$}

This chapter will introduce the history of the Shatțāriyya path in the Indies with a focus on its place among the literary and political elite of the palace of Surakarta in the early nineteenth century. ${ }^{13}$ An understanding of the tarekat within these palace circles will be drawn from an exploration of a selection of manuscripts containing Shațtārī teachings, most of which are stored in the Surakarta archives. I will touch on some of these Shatțārī teachings as they appear in the two Ronggasasmitan suluk, with the hope that this may provide some sense of the tarekat's teachings in the specific Javanese literary contexts to which they belong. Finally, I will briefly remark on the apparent decline in the status of the Shațāaniyya tarekat within court circles and elsewhere in Java after 1830 .

\section{A BRIEF HISTORY OF THE SHATTṬĀRIYYA IN THE MALAY WORLD WITH A FOCUS ON SURAKARTA}

The Shattāariyya was brought to the Malay world by one of Ronggasasmita's spiritual forefathers, that is, the remarkable Sufi scholar 'Abd al-Ra' üf Singkel 
(ca. 1620-1693), whose family hailed from Aceh's west coast. He was initiated into the lineage in the holy city of Medina around the middle of the seventeenth century, having come to the Hijaz around 1642 to perform the hajj and to pursue advanced studies of Islam. This was a time of significant conflict among Aceh's Muslims: the Sufi teachings of 'Abd al-Ra'ūf's “elder kinsman," the poetscholar Ḥamza Fanșūrī (d. 1527?), along with those of Fanșūrī's epigone Shams al-Dīn Pasai (a.k.a. al-Sumațrā'̄̄/al-Sumațrān̄̄, d. 1630), were under assault at the Acehnese court. ${ }^{14}$ The teachings of both Hamza and Shams al-Dīn, which had been ascendant in Aceh during the reign of Sultan Iskandar Muda (r. 16071636), were ruled heresy by his successor Iskandar Thani, under the influence of a new arrival among the Islamic scholars at his court, Nūr al-Dīn al-Rānīrī (d. 1658; in Aceh 1637-1644). The next few years formed the high point, or, perhaps better, the low point, of the controversy over the metaphysical teachings that had come to be known as wahdatul wujud (Ar. wahdat al-wujūd, "the oneness of Being"). ${ }^{15}$ Books were burned and followers who refused to recant were put to death. It is not at all unlikely that the young 'Abd al-Ra'üf made for the holy lands at this precise moment in part to escape the unpleasantness, if not the purge. 'Abd al-Ra'üf spent almost twenty years in Arabia, where he received the teachings of the Shațtāiriyya from the renowned Medinan Sufi scholar Shaykh Aḥmad al-Qushāshī (1583-1661). ${ }^{16}$ After his return to Aceh in the early 1660s, 'Abd al-Ra'ūf remained in contact with the then-Shațāāī shaykh in Medina, the well-known Ibrāhīm al-Kūrān̄̄ (1614-1690). ${ }^{17}$ While firmly establishing the Shațāriyya in late seventeenth-century Aceh, 'Abd al-Ra'ūf disseminated among his students one of its most characteristic teachings, that of the seven levels of being (martabat tujuh) articulated in the Self-Manifestation (tajallī) of God. ${ }^{18} \mathrm{He}$ also produced the first complete Malay tafsir (interpretation) of the Qur'ān, translated a number of Sufi and other works into Malay, composed his own original works in both Malay and Arabic, and served as the $q \bar{a} d \bar{l}$; (chief judge and minister) of the sultanate.

Among 'Abd al-Ra'ūf's students was Shaykh Haji Abdul Muhyi ('Abd al-Muhȳī, ca. 1640-ca. 1715) of Karang, a Javanese Muslim scholar from the central Javanese kingdom of Mataram, who, sometime after receiving the Shațtāriyya teachings from 'Abd al-Ra'ūf, removed himself to the kingdom of Banten and settled in the hills of southwest Java not too far from the coast. ${ }^{19}$ 'Abd al-Muhyī was probably a student of 'Abd al-Ra' ūf in Aceh following the shaykh's return to Sumatra in the early 1660s. Nevertheless, as 'Abd al-Muhyī himself was a hajji, it is at least possible that the two met and studied together in the holy land. ${ }^{20}$ Manuscript witnesses of 'Abd al-Muhȳ̄'s teachings, which include elaborations on the seven grades of being, can be found in the Surakartan royal manuscripts. ${ }^{21}$

Some have suggested that 'Abd al-Muhyī's son Fakih Ibrahim may have served as the chief religious official in the Surakartan court under Pakubuwana 
II (r. Surakarta, 1745-1749) and Pakubuwana III (r. 1749-1788). ${ }^{22}$ That Pakubuwana II sought and ultimately failed to reign as an exemplary Sufi king in Kartasura before removing his palace to Surakarta has been explored in detail by Merle Ricklefs in his Seen and Unseen Worlds in Java. ${ }^{23}$ Ricklefs' fascinating study reveals, among many other things, the central role that the king's grandmother Ratu Pakubuwana (d. 1732) played in this endeavor. Ratu Pakubuwana was queen to the first of the Pakubuwanas ("Axes of the World"), a royal name that was no doubt created to recall the wali kutub (Ar. qutb), the hidden "axial saint" of the age on whom all phenomenal existence metaphysically depends. In the sole (surviving) literary text attributed to Pakubuwana II, however, we find none of the Shatțārī-scented metaphysical speculations that characterize Javanese suluk literature. This Pakubuwanan text is a moralistic-didactic poem that emphasizes the necessity of strict adherence to Islam's ritual obligations and that contains sharp criticisms of any who dare stray from the sharī'a (Islamic law). ${ }^{24}$ The writings of his son and successor, Pakubuwana III (r. 1749-1788), do, however, reverberate with echoes of Shațtāīī metaphysical teachings. Among the suluk composed by Pakubuwana III is Suluk Martabat Wahdat Wakidiyat, a song that lingers on the seven grades of being that were elaborated by 'Abd al-Ra' ūf and 'Abd al-Muhȳi. The text composes a particularly subtle meditation on the second and third grades (wahda and wähidiyya) that form the most sublime levels of God's self-manifestation within Himself and on the dissolution of the self into the godhead that is experienced in perfect gnosis. ${ }^{25}$

If no clear genealogy from 'Abd al-Muhyī to these Pakubuwanan kings has yet been uncovered in the archives, I have found a tiny handful of manuscript witnesses in which the Shațāin̄ spiritual lineages of other noble Surakartan literati are explicitly traced to this saint. All but one of these are witnesses of Ronggasasmita's Suluk Martabat Sanga, one of the songs comprising Suluk Acih. In the Ronggasasmitan genealogy that begins with the Prophet Muhammad, it is attested that the teachings passed from 'Abd al-Muhȳī to his son, Dalem Bojong, and then on to his son, Kyai Mas, and then on to Kyai Talabudinu of Banyumas, who passed them to Syakh Muhammad Salim of Madahab, Ronggasasmita's teacher. ${ }^{26}$ The sole exceptional manuscript is a prose handbook of Shațtārī practices and thought that was composed by a prominent Surakartan statesman, probably around the turn of the nineteenth century. ${ }^{27}$ This statesman, Kyai Tumenggung Arungbinang, traces his Shațāāī lineage to 'Abd al-Muhyē through a different line of masters. The Shațāāì teachings that Arungbinang received passed from 'Abd al-Muhȳ to another of his sons (or, perhaps, grandson), one Mas Bagus Muhyidin. ${ }^{28}$ Bagus Muhyidin then passed them to Kyai Mufid of Kedhung Lo, Roma, who taught Abdul Gani of Tersana, Kedhu. Abdul Gani was Arungbinang's teacher. ${ }^{29}$ Arungbinang provides this silsila in the preface to Bab Dérah ing Ngèlmi Tarèk Wiriding Dikir (On diagrams of tarekat knowledges and zikir litanies/practices), the treatise of 
Shattāaniyya knowledge that he compiled. It is notable that what appears to be the only extant witness of this early nineteenth-century treatise was inscribed in 1864 for a prominent Surakartan prince in a manuscript that also includes a witness of Ronggasasmita's Suluk Acih, of which Suluk Martabat Sanga is part. ${ }^{30}$ Arungbinang, a courtier of I.S.K.S. Pakubuwana IV (r. 1788-1820), was a well-connected statesman in the late eighteenth- and early nineteenth-century Surakartan palace. In addition to his own service to the king, he was also the father of the Surakartan patih (vizier) Sasradiningrat III (in office 18461866) and the step-grandfather of K.G.P.H. Cakradiningrat (d. 1882), the also very well connected Surakartan noble who commissioned the copy of the 1864 manuscript containing Arungbinang's treatise of Shațāiriyya knowledge and Ronggasasmita's Suluk Acih. ${ }^{31}$

The Arungbinang Shațāāi treatise is an extensive prose treatise on the tarekat's thought and practice. It is, in effect, a manual to instruct and enlighten the traveler along the mystic path, providing a detailed guide to the Shațāāi initiation ritual and a great number of zikir texts with recitation instructions that include breathing practices and bodily postures. ${ }^{32}$ The greater portion of the text forms a treatise on Shattāin̄ metaphysics, with extensive meditations on cosmology and on "anthropology" - in the sense of teachings on the metaphysics of the human body, the mysteries of human gestation, and the means by which to open the body's metaphysical potentials (a number of these provided with diagrams, or dérah). As would be expected in a Shațāāi text, discussions of the seven grades of being and the seven levels of the soul's attainments figure prominently. Also of interest are teachings concerning the relations of teachers and students and on the different categories of students. In addition to this extraordinary compilation of Shatțārī knowledge, Arungbinang is also known to have composed a remarkable suluk that forms an extended metaphysical meditation on the nature of ritual prayer, or salat (Ar. salāt), culminating in reflections on the perfection of salat in its eternal and everlasting form (salat daim). ${ }^{33}$

Another particularly striking Surakartan initiate into the Shatțāriyya appears to have been the Surakartan king, I.S.K.S. Pakubuwana IV (r. 17881820), whom Arungbinang served. Pakubuwana IV is celebrated as an author, most notably of the didactic text Wulang Rèh (Teachings on rule), a moral handbook for members of the ruling class that he composed in 1809. It has gone almost unnoticed, however, that he also composed a number of suluk. The king composed these suluk over a period of nearly forty years - from the time that he was a young crown prince until the year preceding his death. These Pakubuwanan suluk, concerned especially with the metaphysical and cosmological natures of the human body, are redolent with the scent of Shațtāin teachings. ${ }^{34}$ It is also of note that Pakubuwana IV chose the name Radèn Ayu Satariyah (i.e., Shațtāriyya) for his first daughter from a queen; he named his second daughter from the same queen Radèn Ayu Kisbandiyah (i.e., Naqshbandiyya), suggesting that the king was also affiliated with the Naqshbandiyya tarekat. ${ }^{35}$ 
Muhammad Arif of Banjar was Pakubuwana IV's teacher and probably his Shattāanriyya master. We learn this in the very truncated spiritual genealogy that M. Ng. Tepasonta II, one of Pakubuwana IV's courtiers, provides in his 1820 redaction of Suluk Martabat Sanga.$^{36}$ In this version, which by today's standards would count as plagiarism, Tepasonta repeats Ronggasasmita's teachings — and his educational biography_-verbatim while usurping Ronggasasmita's place as author. ${ }^{37}$ Dispensing with the Shațtāriyya lineage from the Prophet Muhammad through numerous generations of masters down to Ronggasasmita that belongs to this poem and its teachings, Tepasonta instead begins his genealogy with Muhammad Arif-his own guru. He compensates for this erasure of lineage by noting that Pakubuwana IV was his fellow student under Muhammad Arif and by adding other biographical and genealogical notes - these concerning his own court position and those of his ancestors.

Another Kraton Surakarta text redolent with Shațārī teachings is the Serat Centhini, among the most celebrated of all works of Javanese literature. The Centhini was commissioned by the then-crown prince of Surakarta, who would later reign as I.S.K.S. Pakubuwana V (1820-1823) in January 1815-exactly one month before Ronggasasmita would commence his writing in Aceh. ${ }^{38}$ Composed by a team of court poets that was led by Mas Ronggasutrasna, $\mathrm{Ki} \mathrm{Ng}$. Sastradipura, and R. Ng. Yasadipura II (Ronggasasmita's father), along with the crown prince himself, the 722-canto Centhini is often called an encyclopedia of Javanese knowledge. The Centhini incorporates a large body of suluk literature, and recognizably Shaț̣āī teachings, though usually unattributed, pervade these suluk. Given the apparent prominence of the Shațāiriyya among Surakartan literati at the time of its composition, it is not at all surprising that Shațāāi teachings are so pervasive in the Centhini - and that it was not deemed necessary to attribute them. In addition to the unattributed teachings, Shațtāin practices are explicitly mentioned a number of times in the Centhini-notably as the spiritual practice of Amongraga, the "hero" of the poem. These practices are usually conjoined with those of the Naqshbandiyya, as "Satariyah Isbandiyah," indicating that the discipline of the character Amongraga, like that of Pakubuwana IV, seems to have formed an amalgam of the practices of both tarekat. ${ }^{39}$

There is very strong evidence that the historical figure Kyai Maja (ca. 17921849), a figure whose ties with the Surakarta palace are often overlooked, was also a disciple of the Shațāariyya. ${ }^{40}$ Kyai Maja is remembered today as the principal religious advisor of Prince Dipanagara (1785-1855), the charismatic Yogyakartan prince who led the rebellion against Dutch authority that later became known as the Dipanagara War (1825-1830). ${ }^{41}$ That ultimately failed rebellion formed the last stand of Javanese royal power against the Europeans. Maja had been a teacher in a rural religious establishment endowed by the Surakarta palace, and he was known to have been very close to members of its royal family. ${ }^{42}$ Among his intimate associates was Pakubuwana IV's brother Buminata, the prince who, after his brother's death in 1820 , led the crown 
prince's administration in which Ronggasasmita and his kinsmen served. ${ }^{43}$ Kyai Maja stood at the center of the powerful network of Islamic teachers that provided the core backing for Dipanagara's rebellion. It would not be farfetched to presume that this network was a Shațtāinyya one. Furthermore, with Kyai Maja as his spiritual guide, it is not surprising that Prince Dipanagara, too, appears to have been an adherent of Shațāāi knowledge and practice. ${ }^{44}$ With the failure of the rebellion and the exiles of Kyai Maja in 1828 and of Dipanagara and Surakarta's king Pakubuwana VI in 1830, the old royal order of Java was over.

The year 1830 was a watershed year in Javanese social and political history: it marked the end of indigenous royal political power and the beginning of high colonialism in Java. The defeat also appears to have delivered a blow to the ascendance of the Shațāariyya at the Surakarta court, on which I will elaborate further in the conclusion of this chapter. There is reason to believe that the Shatțārī court poet Mas Ronggasasmita - along with the pujongga Ronggawarsita's fatherwere among the casualties of that war. To my knowledge, no new Shațāari texts were composed at the court after the war--although the older Shatțāriyya manuscripts continued to be copied, redacted, and circulated. ${ }^{45}$

\section{THE WRITING OF SULUK ACIH}

Some ten years before the outbreak of the Dipanagara War, the Javanese court poet Ronggasasmita composed his collection of Shatțāāi Sufi poems in far-off Aceh. Ronggasasmita almost certainly composed this work in the course of an interrupted pilgrimage to Mekka. Stranded in Aceh, the so-called Veranda of Mekka through which pilgrims from the archipelago often passed, the poet, speaking in the third person, notes that his writing

[10] Was at the time that he was cast adrift by God

Separated from his companions

In the land of Aceh overseas

Just the two of them, he and his uncle Yakir.

[11] But his uncle, fallen ill with a fever

Weeks on end, sorrowful of heart

Could not be drawn to speak.

The writing began on a Friday, in the month of Rabinguawal

[12] On the seventh day, in the year Jé, in the seventh season

Rendered in chronogram:

"Pure Countenance of the Priest King" [17 February 1815]. ${ }^{46}$

$(\text { Suluk Acih })^{47}$ 
For pilgrims from south-central Java in the era before the steamship, performing the hajj in Mekka entailed, to be sure, an arduous journey. ${ }^{48}$ We do not know how long the preparations had taken for our two pilgrims' voyage or how long they might have waited for this opportunity. We do know that the Haramayn had been under Wahhābī control from 1806 to 1813, which would have made Mekka less than conducive to Sufi practitioners. ${ }^{49}$

Ronggasasmita and his uncle probably set sail from the port of Semarang on Java's north coast in the fall of 1814 to journey westward and northward for over 1,300 miles - across the north coast of Java and then up through the Straits of Malacca to Aceh. The pilgrims would have needed to embark from Aceh sometime between late December and early February in order to catch the monsoon winds for the 4,000-mile trip across the Indian Ocean in order to arrive in time for the hajj season in November $1815 .{ }^{50}$ Ronggasasmita began composing his suluk on February 17, 1815; owing to his uncle's illness, he had just missed the boat. We do not know whether he waited in Aceh for the next season's boat out to Aden or if he and his ailing uncle tarried there until they could catch a boat back to Java - though I am inclined to think that the poet did bide his time in Aceh, writing, and that he likely did make the hajj the following year, for, as I suggested at the opening of this chapter, I am also inclined to think that he was the "Mas Haji" who was exiled along with his elder brother in 1828. Until evidence is unearthed to prove or disprove my supposition, all that we know for sure is that in February 1815 the poet was cast off, stranded, and despondent over the interruption in his pilgrimage. At this time of intense disappointment_-indeed, of a broken heart-Ronggasasmita decided to divulge in poetry the teachings of his Shatțārī masters. And so he set himself to writing:

[6] The elect knowledge of Reality

The truth that

Brings perfection to life

The knowledge that is forbidden

[7] Secreted by the prophets, the saints, and the faithful.

In former times there was none

Who dared render it in verse;

For so secret is this knowledge.

[8] The first to render it in verse, in Pucung meter

Is Dyan Ronggasasmita

Charging headlong, revealing the secret

All the teachings of his master[s] 
[9] All those bound in primbon books ${ }^{51}$

Here are set to verse

To be a journey of knowledge [suluking ngèlmi]

Deliverance for a broken heart

$\left(\right.$ Suluk Acih) ${ }^{52}$

The suluk forms a poetic journey along the mystical path, and that path was a Shațārī one. Was this journey, in part, to replace the journey to the holy land that the poet was forced to defer? What form of secret teachings could salve the wound that this interruption in the poet's pilgrimage had inflicted? Before touching on the nature of the secret teachings that Ronggasasmita so boldly reveals in his suluk, a word on his background is in order.

\section{THE BACKGROUND OF THE WRITER: FAMILY AND EDUCATION}

Ronggasasmita belonged to one of the most distinguished and powerful literary families in Java. His grandfather, R. Ng. Yasadipura I (1729-1803), is among the most renowned of Javanese literati. Yasadipura I is most remembered for his translations of the Old Javanese classics (e.g., the Ramayana and the Mahabharata) into modern Javanese verse. However, his writings are not restricted to just the Indic classics: he is also credited with a masterful history that chronicles the war of the division of Java (1746-1757) through which he lived, ${ }^{53}$ a poetic history of an important case of Islamic polemics in eighteenthcentury Java, ${ }^{54}$ a voluminous poetic rendering of the adventures of the Prophet's uncle Amīr Hamza, ${ }^{55}$ the renowned Déwaruci tale of the Mahabharata hero Bima's mystical journey in search of the water of life (notably classified as a suluk in the Kraton Surakarta archives), ${ }^{56}$ and at least one other poem that is more easily recognizable as suluk. ${ }^{57}$ Yasadipura I was also an avid reader of suluk literature, as Ronggasasmita attests in his Suluk Martabat Sanga, and a close confidant of Surakarta's king I.S.K.S. Pakubuwana III (r. 1749-1788), who, as noted above, was himself an author of suluk infused with Shațāāī thought.

Yasadipura I's son and Ronggasasmita's father, R. T. Sastranagara (a.k.a. Yasadipura II, 1756-1844), was both a prolific writer and a major statesman, serving as the senior minister of the Surakarta palace's Kadipatèn from 1826 to his death. ${ }^{58}$ Sastranagara produced a range of literary works: in addition to participating in the composition of the encyclopedic Centhini, he also wrote historical chronicles, commentaries on good and bad statecraft, moralistic manuals for the ruling class, translations of the Old Javanese classics into modern Javanese poetry (and, conversely, translations of modern Javanese poetry into Old Javanese classical meters), voluminous histories of the Islamic prophets (Serat Ambiya), and, perhaps most relevant here, at least two suluk. One of those admonishes his children to study, to work with written materials and with properly qualified masters in order to achieve perfection, especially 
perfection in death; the other suluk provides a sense of what that perfection might mean, and that would appear to be the perfect embodiment of spirit in both life and death. ${ }^{59}$

Ronggasasmita seems to have followed his father's directions in seeking out a spiritual education, though he was not always entirely successful in this endeavor; we learn this in an unprecedented narrative that is tucked away in one of the poems that compose his Suluk Acih. In the section of Suluk Martabat Sanga immediately following the secret teachings on the nine grades of the Prophet Muhammad's being, which open the suluk, and immediately preceding the poet's Shatțāriyya genealogy, Ronggasasmita provides a concise autobiographical narrative of his early educational journey. I should note that this is the only such first-person narrative on a Javanese subject's spiritual education that I have encountered in any traditional Javanese text. The narrative begins with a specific prohibition: Ronggasasmita instructs his students and children to conceal the esoteric teachings that he has newly disclosed to them from what he calls the "shari'a folk" (Jv. ahli sarak), the community of those whose main concern is Islamic Law, a community to which he himself once belonged: ${ }^{60}$

[38] Keep this hidden, fenced away closed tight

Those belonging to the sharī'a folk [ahli sarak]

Are forbidden [siriken], let it not be known to them.

Even with others, you must take care.

[39] I give so strong a warning because

It has been truly demonstrated:

I myself did once become

One of the sharīa folk, but not as learned as the 'ulama'

[accomplished religious scholars]

[40] Still stupid [maksih busuk], nevertheless I took a guru [anggeguru].

And this first time

It did not penetrate my heart,

So I took another guru, the second time still

[41] My heart was confused: like yes, like no

Scored by sharī'a

Terrified of death.

Again I took a guru, this then was my third.

[42] At last I began to understand,

But still not rid of

The traces of sharī'a, troubled

Day and night my heart did roil in argument. 
[43] Over and again my position I turned

On the secret knowledge [rahsiya]

Lost in twisted argument [kapulintir]

In frustration, I took no heed

[44] Heedless, again a guru I took.

This then was my fourth.

And there my heart, now strong [gagah]

Received the revelation [wahyu], the gift of grace [nugraha],

[45] Completed, opened and cleansed was my heart.

No longer was it shrouded

Gone were all the screens

Mad, ecstatic, now assured.

[46] Ever stronger, my passion [birahèningsun] for knowledge

Ceaselessly seeking teachers [puruhita]

From them to learn of that within [batin].

Now wholly dedicated, I did not spare expense.

[47] The taking of gurus I took to its end:

Within [batin] I was untroubled

But outwardly [lahiré] I did conceal that

Ritual performance [angibadah] was useless [tanpa pédah] then for me

[48] Like a dul, my zikir knew no set times ${ }^{61}$

My ratib and sama, ceaseless ${ }^{62}$

I gathered all the hajjis

Finally then impoverished by hosting all those feasts.

[49] All ye, young and old, my followers all

Know ye all

The lineage of my gurus

This exceeds in excellence reading the Qur'ān.

[50] My gurus were not many, only twenty-three

But I am counting only

The lineage of but one:

Whose foundation came from our Master 
[51] For it was first the Messenger of God who taught

Sayidina Ali

The son of bin Talib.

Then Sayidina Ali taught ...

${\text { (Suluk Martabat Sanga })^{63}}^{3}$

The Shaț̣āriyya spiritual genealogy that begins with the Prophet Muhammad continues on through twenty-eight generations of gurus before coming to Ronggasasmita's Shațtāin master, Shaykh Muhammad Salim of "Madahab," that one guru whose lineage "counted." ${ }^{" 64}$ Ronggasasmita was, then, the thirtieth in the lineage.

It is no doubt significant that the poet chose to preface his distinguished Shattāiariyya genealogy with an outline of what had been his sketchy educational journey as a young spiritual seeker. In doing this, Ronggasasmita seems to be both censuring and celebrating the educational failures he experienced at the start of his quest and the excesses in which he indulged toward the end of his journey - and to be doing so in the interface between revealing the deepest esoteric knowledge of the Prophetic Reality and authorizing that knowledge with the pedigree of his Shattāain heritage. At the end of his (preliminary) journey, he is like a santri dul, mad and ecstatic in his embrace and his practices; he impoverishes himself by holding feasts for all the religious. Did these excesses precede or succeed Ronggasasmita's entrance into the Shațtāinyya? Where is Shaykh Muhammad Salim of Madahab, that one teacher that counted, located in this narrative? Is he the favored fourth guru under whose guidance Ronggasasmita's heart was opened to the revelation, an experience that was followed by the poet's indulgence in unregulated "mystic excess"? Or was he perhaps one of those hajjis who enjoyed Ronggasasmita's largesse? Or did Shaykh Muhammad Salim come into the poet's life after his impoverishment—after the feasting was over? At the least, I should note that the excesses Ronggasasmita describes here are not consistent with the teachings in the rest of Suluk Martabat Sanga or with the teachings of almost all the other poems normally included in the Suluk Acih compilation. ${ }^{65}$

Ronggasasmita notes that it was only after having been frustrated in his study of sharī'a, and still in a state of ignorant stupidity (maksih busuk), that he turned to the world of (Sufi) gurus (anggeguru). Narrating the difficulties he encountered on the path, he may then be describing the pitfalls into which one who is too steeped in the petty details of sharīa - though not truly learned like the ' $u l a m \vec{a}$ ' - may fall when confronted with esoteric Sufi knowledge. He does, after all, explicitly cite his own stumbling experience with his gurus as evidence of the impediments to Sufi practice faced by a half-baked student of sharīa. But is this the prime reason that the secret knowledge is forbidden to the sharīa folk? Or is this prohibition rather a warning to his students to keep what he 
has taught them secret lest they be misunderstood and perhaps punished by the sharī'a folk? There is, in Javanese historical texts as well as in suluk, a tradition of writings concerning such misunderstandings and punishments, most notably in narratives of the martyrdom of the "heretic" saint Sèh Sitijenar that is thought to have taken place in fifteenth- or sixteenth-century Demak. ${ }^{66}$ Ronggasasmita does note that, after he finally saw the light, he concealed within himself what had been revealed to him and continued to perform the outward ritual devotions required by Islam (ibadah), something that Sitijenar failed to do. But at the same time Ronggasasmita evaluates that performance as useless or devoid of merit (tanpa pédah). And in the very next stanza - the last before turning to his pedigree-Ronggasasmita describes his very public ecstatic Sufi (Shatțārī or not) practices that fall outside the bounds of prescribed ritual practice, practices that fall out of time (tanpa mangsa) and are marked by an immoderation that eventually beggars him.

\section{RONGGASASMITA'S ADMONITIONS TO THOSE WHO WOULD COME AFTER}

The final portion of Suluk Martabat Sanga, directly following the poet's Shațāariyya silsila, turns on Ronggasasmita's admonitions to his students and his readers, and these are four. The first two of these are dispatched quickly. Ronggasasmita first admonishes those who will come after him "to keep it fast" (dèn-agemi), that is, to conceal the secret teachings from the many; second, he admonishes them "to be scrupulous" (dèn-nastiti), by which he means to be attentive in study and unwavering in conviction. Ronggasasmita lingers, however, on the interconnected third and fourth admonitions. The third admonition is "to be diligent" (dèn-taberi); by "diligence" he means diligence in reading practices, and that which is to be read are suluk. It is here that Ronggasasmita provides the only extended critical reflections on the practice of reading that I have encountered in Javanese manuscripts. These self-conscious, at times almost ethnographic, notes on reading are, I think, unprecedented. For Ronggasasmita, diligent reading entails a kind of critical engagement that is the result both of sufficient understanding of the Javanese Sufi corpus and a dialogical interaction with the text, through which the well-informed reader participates in its production of meaning. ${ }^{67}$ Passive, uncritical reception fails to meet the mark: the practice of diligent reading that he calls for entails the active and informed interpretive practice of the enlightened reader. Such true "diligence" in reading makes it possible for students to distinguish between true and false gurus, a critical distinction for travelers along the mystical path. Finally, Ronggasasmita's fourth admonition to his students is that they "take care" (dèn-ati-ati) in their reading practices. He goes on to explain that "taking care" means attending carefully to the complexity of meaning found within the suluk that are the objects of their study. Every student needs to work actively 
toward the apprehension and experience of these meanings - of this complexity-but, Ronggasasmita cautions, he or she must do so under the guidance of a qualified guru. "Taking care," then, is a function of having already practiced "due diligence." ${ }^{6}$ Only the diligent reader who has taken sufficient care is open to the experience of knowledge.

In this final section of the suluk, Ronggasasmita describes the exemplary reader (and presumably guru) and contrasts his practice and knowledge with that of the charlatans. For Ronggasasmita, the exemplary perfected reader was his own grandfather, R. Ng. Yasadipura I. He tells of watching his grandfather, notably one who was already imbued with knowledge (ahli ngèlmu), pore over texts almost every night, and those texts, he says, were suluk and other Sufi texts.

[76] I myself did see him in the deep of night

When he had no guests

Once resting from his writing

There was nothing other seen by him

[77] Save suluks and other Sufi works ...

(Suluk Martabat Sanga) $^{69}$

Ronggasasmita goes on to compare Yasadipura's reading practices with those of the false gurus "nowadays" who dare to teach without a foundation of diligent reading. These rascally teachers (guru bérnakal) even go so far as to offer interpretations of metaphysical poems that they themselves do not understand, and by "understanding" he means the experiential spiritual understanding that is ngèlmu. They may be clever (bér-ngakal), but their cleverness is built on shaky (if rational) foundations, their interpretations of suluk are trivial, and their teachings lead their students astray. For this, Ronggasasmita tells us, they deserve to have their mouths stuffed with seven fists full of rocks. ${ }^{70}$ As Ronggasasmita reminds us at the close of Suluk Martabat Sanga, if these poems were of no benefit or merit (again tanpa pédah), the saints would never have written them. No, they were written in days of old as teachings for the future. Hence, we must take care in our reading of them. ${ }^{71}$

\section{THE POET'S SHATTṬĀRIYYA TEACHINGS}

This introduction to the articulation of the Shattāariyya among the literati of the early nineteenth-century Kraton Surakarta would be hollow without some attention to the Shațāāī teachings their writings comprise. My discussion here will be brief and restricted to just some of the teachings that are found in just two of the poems that compose Ronggasasmita's Suluk Acih (Suluk Acih "proper" and Suluk Martabat Sanga). Both suluk at heart form reflections on tawhìd (the absolute unicity and uniqueness of God), on the nature of creation, and especially 
on the nature of humanity, the most perfect manifestation of God in creation. Although there is no explicit reference in either text to the insān al-kāmil, the "Perfect Man" who forms the final (seventh) and most sublime self-manifestation of God in the Shațāai discourses of the Malay world, both poems can be understood as explorations of human perfection in and through God. The most perfect of Perfect Men is the Prophet Muḥammad. In Shațāâ̄ teachings, it is through the Prophet's light that creation itself emerges, and it is in his person (both body and soul) that all the potentials of the created universe are realized most completely. Ronggasasmita explores this embodied perfection most explicitly in his Suluk Martabat Sanga with the poetic meditation on the nine grades of created and uncreated being encompassed by the Prophetic Reality with which he opens his song.

Having already discussed the middle and end of Ronggasasmita's Suluk Martabat Sanga, I turn at long last to the opening section of the work and the secret teachings that the poet cautioned should be hidden from the people of sharī'a. These teachings with their elaborations on the very being of the Prophet provide an exemplar of the kind of knowledge that Ronggasasmita tells us is so easy to misinterpret, the kind of knowledge that he says was written to be of benefit in the future. The first thirty-six stanzas of the poem form an intricate reflection on the unfolding of God in creation through the person of Muhammad, the most perfect of Perfect Men. The suluk moves through the nine levels of God's self-manifestation in the Prophetic Reality, each of which is perpetually re-created in Muhammad's perfect human form in the punctual eternal moment "from before there were heaven and earth straight through unto now." In this song, Ronggasasmita celebrates the Prophet in his perfectly realized form as the one who gathers into presence both the infinite potentials of the cosmos and the form of the man Muhammad..$^{72}$ He reflects on the Prophetic Reality reflexively in a way that invites careful readers to join in the reflection and to share in the experience of that eternal moment.

The reflection begins with the Divine Face, unchanging and eternal and made fully manifest in the Prophet, as the palace (kraton) of God that lies within each of us. The journey through the nine levels of the Prophetic Reality descending from the first grade, that of the Face, to the ninth, that of the fixing of the Prophetic form in the person of Muhammad, is an exploration both of the creation of the world and of the generation of humanity, that is, of the gestational process of each and every human being from conception until birth. Ronggasasmita tells us that to follow this journey under the guidance of a perfect teacher is to attain knowledge of the "palace of the self," that is, to learn to "see" the self under the aspect of the divine. The task of the traveler on the mystical path is, then, to follow the Prophet's realization.

Suluk Acih too lingers on the Prophetic Reality. Ronggasasmita both opens and closes Suluk Acih with a version of the well-known Sufi metaphor of the mirror. The knowledge of reality is to be discerned in the knot that this metaphor 
forms. In his extended interpretation of the metaphor that opens the suluk, Ronggasasmita identifies the Perfect Man (that is, the Prophet Muhammad) as the perfect reflection of God in the mirror of the universe, wherein the One who gazes is identical with the reflection on which He gazes. The subject and object of vision are one. The created universe (the mirror) is the reality of negation (nafi). God (the One who sees and His seeing) is the reality of affirmation (isbat). The reflection is the manifestation of God's self-affirmation in the form of the Prophet Muhammad. Finally, in the closing stanzas of the same suluk, Ronggasasmita affirms that whatsoever man or woman completes the journey along the path (suluk), whosoever realizes his or her return, is indistinguishable in his or her reality from the reality of the Prophet, the manifestation of God's essence abiding in the oneness of God's Face. ${ }^{73}$ And, in the end, "the one who is called 'Allāh' in truth/is he who utters 'Allāhu akbār.'"74

Both Suluk Martabat Sanga and Suluk Acih "proper" are exemplars of wujūdi thought. That is, both are extended explorations of the "oneness of being" that explore the absolute unicity of an absolutely transcendent God who is nevertheless immanent in His creation. The suluk turn on the relation of the One to the many, God to His creation, and humanity to God, through reflections on the multiple levels of being, potential being, and potential nonbeing through which God eternally discloses himself in His creation along with reflections on the central position of humanity within that creation. Ronggasasmita's suluk articulate the unity of being, which is ultimately only God's Being, in a manner that can neither be dismissed as vulgar pantheism nor argued to be an abstract monism. ${ }^{75}$ This is effected, in part, by the wit, nuance, and economy of Ronggasasmita's poetic language. There is a terseness of expression in the metaphysical articulations of the being of God and that of humanity that opens Ronggasasmita's poetry not only to multivalent interpretation, but, more important in the context of suluk, to perplexity, to the knowledge of unknowingness (Jv. éram, from the Arabic hayra, "perplexity").

The Javanese language seems particularly suited to the generation and exploration of metaphysical puzzlements. In his rendering and evocation of these moments of wonder, Ronggasasmita plays to maximum effect the ambiguity of Javanese personal pronouns, where a single pronoun (sira) can and does mean "He," "he," and "you"; and another pronoun (kita) can mean both -and at the same time- "I" and "we" and often "you" as well. He makes deft use of the semantic indeterminacy of a number of other critical words in Javanese mystical discourse, such as words that denote "the self"; for example, the word awak is at the same time "self," "person," and "body." The senses of words, then, slip between and among multiple possible meanings, setting off a movement of undecidability that beats in reverberation and opens to wonder. In Javanese poetic phrasing, the agent of an action often remains ambiguous. Ronggasasmita plays with this feature of poetic language to effect productive perplexities that cross and sometimes confound the lines of poetry. 
This is notable, for example, in his reflections on the creative will in the generation of the universe, where the subject of the verb "to will" (and this is the Divine Will) is willfully obscured. Finally, Javanese verbs do not mark tense. Ronggasasmita plays this feature of language, too, to maximum effect, thereby to slip with ease between past and present, time and eternity.

[6]

Who stands in Junun Mukawiyah ["the Face unfurling in the wide world"]?

[7] Yea, the Reality of My Life [sajatiné urip ingsun: the life of God and that of the Prophet, but also that "palace of the self" that is the secret interior "I" of the suluk's writer and of its reader]

Before there did exist

Heaven and earth straight through unto now

As for the will, what is it that was/is willed?

[8] Yea, its name is Maklum Suksma

Maklum means "knowledge"

Suksma is "the will

Not yet to will, but just to know"

[9] Who then stands within Maklum?

Who indeed is it but

The All High, the All Pure

Yea, truly it is my life itself, our lives themselves [iya iku nyata urip kita dhawak: and/or "Yea, the reality of my Life itself, our lives themselves"; and/or "Yea, the manifestation of my life itself, our lives themselves"; and/or "Yea, the Truth of my/your own life"; and so on]

[10] When the heavens and earth were yet to exist

Straight through unto now

And then there was/is another will ...

(Suluk Martabat Sanga) ${ }^{76}$

Finally, I would like to say a word or two on how Ronggasasmita, the writer who is foremost a seeker, understands the relation between the written word and human action. Both suluk take an interest in the status of the written word, of writing itself. Each of them lays claim to participating in distinctive Islamic discursive traditions, and both valorize writing and reading as Sufi practice. Suluk Acih begins by referencing classical theological sources, the 
Ibn Abbās tradition of Qur'ānic interpretation and the renowned eleventh-century theologian al-Ghazālì's (d. 1111) most famous work, the Ihyā' 'ulūm al-dīn (Revivification of the religious sciences) ${ }^{77}$ It continues with translations from Arabic sources that form reflective interpretations of Qur'ānic passages, along with several well-known hadìth and classical Sufi utterances. Suluk Martabat Sanga also opens in dialogue with the Islamic theological tradition of kaläm, and it does so through the sometimes-singular translations of Islamic theological terminology — or of what is taken to be Islamic theological terminology - through which it elaborates the nine grades of the Prophetic Reality. ${ }^{78}$ After completing its intricate exercises of translation, the poem then moves into reflections on knowledge transmission, recording the poet's educational biography (stanzas 39-48), his Shatțāriyya lineage (stanzas 49-67), and his advice on reading and teachers (stanzas 67-84). Finally, the suluk concludes by emphatically locating itself as heir to and participant in the Sufi literary traditions of Java, traditions of merit (Jv. pédah) whose teachings point to a kind of knowledge that is not finally subject to the constraints of the logical mind (Jv. akal).

While valorizing writing, both suluk at the same time prioritize the supradiscursive knowledge that proper reading practices can cultivate. In Suluk Acih, Ronggasasmita cautions his readers repeatedly not to be carried away by the written word, but to bring the word to life, in practice. Similarly, in Suluk Martabat Sanga, readers are warned against the slavish rationality that precludes the experience of unknowingness that marks humanity's ultimate return to God. In their relation to the Islamic written word, both suluk take a critical stance toward the science of jurisprudence. Although neither is hostile to the sharīa itself, both are critical of the overinflation of the law and especially of the narrow interpretations of those who are carried away by an incessant focus on fiqh, the science of shari'a. Suluk Acih is more measured in its criticism than is Suluk Martabat Sanga, which, as we have seen, seems to imply that a focus limited to the law can form an impediment to success along the mystical path. In Suluk Acih, Ronggasasmita is particularly critical of those who think that the final, ultimate wisdom is to be found in the study of jurisprudence at the level of the book - as an academic discursive practice. This, he says, strays into the domain of idolatry of the written word, which he condemns as a form of syirk (polytheism) ${ }^{79}$

For Ronggasasmita, the ultimate wisdom is not to be discovered in academic exercises, but rather realized through other forms of practice, including not only specifically Shațāriyya ritual and knowledge practices, but also the social action that the fully realized man or woman will perform in the course of his or her everyday life. This complex of praxis culminates in the supradiscursive experience of mairifa (gnosis), in which the perfected practitioner then abides. The mark of one who has come to Real knowledge-who has achieved the divine end (and simultaneously the divine beginning) of his or 
her mystical journey - is not the mastery of writing but to have been dissolved into all writing slates and all writing - to have been dissolved into all life. ${ }^{80} \mathrm{In}$ Ronggasasmita's suluk, the end is not in disembodied abstraction, but in the dissolution of the perfectly realized man into life. His suluk, like those composed by his ancestors whether by blood or by spirit, were written to be useful - to have pédah. The suluk were composed to draw those who could read them carefully toward a state of productive perplexity, a space out of which they could move from venal worldliness to the realization of a form of worldly perfection like that most perfectly embodied by the Prophet - to lead them to experience what it is to "die before you die" and to sustain that experience in lives of purposeful action. The final lines of Suluk Martabat Sanga read:

[83]

It is impossible that the saints would have

[84] Written the suluks were they without merit [pédah]

Nay, they were created

As teachings for the future

So by "taking care" I mean

[85] Don't drown in the life of this world

Within your lives of valor [kawiryan]

Live in practiced mindfulness [prihatin]

To die before dying - in life!

(Suluk Martabat Sanga) $^{81}$

\section{THE SHATTTĀRIYYA IN JAVA AFTER 1830}

I will conclude this cursory introduction to the Shațāinyya in the literary world of the Kraton Surakarta with some preliminary notes on the shifting position of the tarekat after 1830. An examination of manuscripts now stored in the three royal repositories of Surakarta suggests that the composition of new Shațāaīscented suluk by the court's literati came to a near standstill with the close of the Dipanagara War. This apparently sudden shift in literary practice was no doubt a consequence, in part, of the vicissitudes of that war. Prince Dipanagara and his spiritual advisor, Kyai Maja, were both disciples of the Shatțāriyya, as no doubt were many, if not most, of the Islamic teachers who provided the core support of the rebellion. With their defeat and with the shifting policies of the colonial government toward "political Islam" in the wake of that war, Shattāāī Sufism as a subject for literary composition may well have become an uncomfortable, if not dangerous, prospect for court literati. ${ }^{82}$ As we have seen, several members of Surakarta's Yasadipuran literary family, almost certainly 
including Ronggasasmita, had disappeared into exile in the course of that war. The apparent decline of the Shatțāriyya after 1830 was not, however, confined to the literary circles of the Surakarta palace and was not merely a function of local political developments.

By the second half of the nineteenth century, it was a newly invigorated Naqshbandiyya that was becoming ascendant across Java as the Shaț̣āriyya was fading into the background. Reflecting developments that were sweeping across the Muslim world, the Naqshbandiyya of this period bore distinct "reformist" characteristics: it appears to have placed more emphasis on observation of the five pillars of Islamic practice than had the Shațtāinyya —or, for that matter, the earlier Naqshbandiyya.$^{83}$ It also attracted a more popular following than appears to have been the case for the earlier tarekat.$^{84}$ Surviving manuscript evidence suggests that the earlier Naqshbandiyya and the Shațtāinya may have been reserved to more elite circles (royals, high officials, and religious teachers-including those in the countryside, many of whom, like Kyai Maja, were associated with the court). ${ }^{85}$ No doubt the reformed Naqshbandiyya generated both new lineages and new, more expansive, networks.

The success of the Naqshbandiyya in its competition with the Shațāriyya for adherents in the Malay world was no doubt accelerated by the increased flow of ideas and pilgrims to and from the Hijaz and the archipelago made possible by the advent of steam travel and the opening of the Suez Canal in 1869. Malay pilgrims were always highly attuned to developments in the Haramayn, and, by the later years of the nineteenth century, the Shatțāriyya had become unfashionable in Mekka. The aspirant Sufi practitioners from the Jāwī world sojourning in the Haramayn were instead flocking to the Naqshbandiyya - as well as to the new Qādiriyya wa'l-Naqshbandiyya order. ${ }^{86}$ The greatly expanded body of returning pilgrims brought the newly ascendant Naqsyabandiyya and Qādiriyya wa'l-Naqshbandiyya teachings back to Java with them. It is not at all surprising that it was these lineages and disciplines, then, that found favor among the spiritual seekers of Java who revered and followed these hajjis.

The prominence of the Naqshbandiyya at the Surakarta court (and other royal circles) in the early 1880s is well documented in Michael Laffan's study of changing Dutch perceptions of Islam in Java ${ }^{87}$ However, by the end of the century the Naqshbandiyya, too, appear to have faded from the palace scene. ${ }^{88}$ At the very least, there is manuscript evidence from 1885 attesting that there were members of court society who heavily censured the Naqshbandīs and their practices, prescribing instead even more recently "reformed" models of Islamic practice ${ }^{89}$ Although suluk, including Shatțārī suluk, continued to be copied and circulated in manuscript form among Surakartan elites up through the early twentieth century, a survey of suluk texts in the Surakarta palace suggests that there was a sharp drop in this manuscript production at the court after 1886. Fewer suluk were copied, and almost no new suluk were composed. 
After that time, the (notably few) new "mystical" manuscripts that were produced in court circles had taken a turn toward what was thought a specifically Javanese mysticism (kejawèn) that was sometimes colored by theosophical speculations.

Perhaps anticipating this turn to what were to be understood as specifically Javanese knowledges, in 1850 Ronggasasmita's celebrated nephew, the pujongga Ronggawarsita (1802-1873), compiled his prose treatise of Muslim mystical doctrine and practice that he titled Wirid Hidayat Jati (Litany of true guidance).${ }^{90}$ Many of the knowledges presented in this treatise bear resemblance to those found in Shattāāī texts. But there are also significant differences. The teachings are not attributed to a Shatțārī tradition that traces its lineage back to the Prophet Muhammad; rather, the teachings provided in this True Guidance are said to have originated in Java, to have been first composed by eight of the usually nine saints (wali) credited with having brought Islam to Java. ${ }^{91}$ According to Ronggawarsita, each of these Javanese saints created his own school of mystical knowledge. But, while establishing these schools as specifically Javanese, Ronggawarsita was also careful to emphasize that each of them was based firmly in the four principal sources of Islamic law: the Qur'ān, hadìth, ijmā', and qiyās. These eight "schools" progressed through four generations of eight Javanese saints, finally to be brought together as one under the guidance of Sultan Agung, who ruled the kingdom of Mataram in the first half of the seventeenth century. ${ }^{92}$ It is the eight combined as one by the king that form the "True Guidance." Toward the close of his treatise, Ronggawarsita differentiates this true guidance from other lesser forms of knowledge (ngèlmu). These lesser forms are instrumental knowledges concerned, he says, with performing miracles (ngèlmu talèk) and unlocking the spirit world (ngèlmu patah). Ronggawarsita enumerates nine forms of ngèlmu patah..$^{93}$ Among the knowledges that he categorizes as forms of "spiritism" are, shockingly, the teachings of the Shațāariyya - along with those of the Naqshbandiyya, Majalis, Sufi, Khahfi, and Patahulrahman. The less than positive evaluation of the remaining three ngèlmus is less surprising as they are more recognizable as what could be considered magical-mystical forms of knowledge. None of the nine, he emphasizes, is congruent with true spiritual knowledge, and all of them can lead to argument and thus ultimately to unbelief. ${ }^{94}$

And yet there is evidence suggesting that Ronggawarsita himself was a Shattāāī master. A solitary manuscript witness of his uncle Ronggasasmita's Suluk Martabat Sanga that was inscribed in Surakarta in 1872, a year before the pujongga's death, continues Ronggasasmita's Shattāāi genealogy for two more generations. According to this witness, Ronggasasmita passed the Shațtārī teachings on to none other than said nephew Ronggawarsita, who in turn guided two lower-level Kraton Surakarta courtiers along the path. ${ }^{95}$ Although Ronggawarsita is not-and apparently would not have been pleased to be-remembered as a disciple (much less a murshid) of the Shatțāriyya, this 
manuscript evidence suggests otherwise. Perhaps the "seal of the pujongga" felt it necessary to disguise his Shatțāriyya genealogy in the wake of the Dipanagara War that had claimed his father, the elder Ronggawarsita, and his uncle, the hajji Ronggasasmita who authored the suluk that has been at the heart of this chapter.

\section{NOTES}

I am grateful to Anne Blackburn and Michael Feener for their helpful comments on earlier drafts of this chapter. Any mistakes and shortcomings remain my own.

1. That the elder Ronggawarsita was exiled is sufficiently well known; that his younger brother was exiled along with him, however, appears to have vanished from historical memory. An entry in a prose dynastic history composed in the Surakarta palace around 1831 records the exile of the two brothers: "Mas Ronggawarsita, Mantri Lurah Carik of the crown prince's administration, was exiled by the Dutch government along with his younger brother, Mas Haji, in punishment for their involvement in the rebellion of Prince Dipanagara on Friday, the 24th of Sawal Alip 1755 [May 9, 1828]" (Serat Babad Sangkala kang Urut saking Kagungan Dalem Serat Babad [composed and inscribed in the Kraton Surakarta, ca. 1831], ms. Kraton Surakarta [henceforth KS] 1 C [6 Ta], p. 127). For a comprehensive history of the Dipanagara War, see Peter Carey's The Power of Prophecy: Prince Dipanagara and the End of an Old Order in Java, 1785-1855 (Leiden: KITLV Press, 2008).

2. A pujongga is a poet-scholar who has received the revealed divine power (wahyu) of prophecy. It also names an office in the palace of the Kraton Surakarta. Yasadipura I, Yasadipura II, and the younger Ronggawarsita were the last three to hold this office. After his death, Ronggawarsita was known as the seal (panutup) of the pujongga, echoing the Prophet Muhammad's distinction as the "seal of the prophets" (nabi panutup). For more on this literati family and on the problematic of the Surakarta "literary renaissance," see Nancy K. Florida, "Writing Traditions in Colonial Java: The Question of Islam," in Cultures of Scholarship, edited by S. C. Humphreys (Ann Arbor: University of Michigan Press, 1997), pp. 187-217.

3. The overwhelming majority of texts belonging to Javanese manuscript literature are anonymous. R. T. Sastranagara, Ronggasasmita's father, was one of the very few early nineteenth-century authors who identified himself in some of his works. From around the middle of the nineteenth century, a practice known as sandiasma appeared in which some authors - notably the pujongga Ronggawarsita — signed their compositions in acrostics embedded in the opening lines of their works. The style of Ronggasasmita's "signatures" in these two Suluk Acih texts is truly exceptional. In Suluk Acih "proper" he not only identifies himself, but also notes the historical circumstances of the poem's composition. In Suluk Martabat Sanga, Ronggasasmita identifies himself in the uniquely versified Shațtāin silsila that he provides following the extremely rare - that is, the only one that I am aware of - narrative describing his early educational experiences.

4. For descriptions of these manuscripts, the oldest of which was inscribed in 1845 and the youngest in the early twentieth century, see Nancy K. Florida, Javanese Literature in Surakarta Manuscripts, vols. 1-3 (New York: Cornell University SEAP, 1993, 2000, 2012).

5. On the Leiden manuscripts and for preliminary philological notes on the suluk, see Edwin Wieringa, "Aanvullende gegevens over de Suluk Acih van Ranggasasmita," Bijdragen tot de Taal-, Land- en Volkenkunde 149.2 (1993): 362-373. 
6. Ronggasasmita provides his Shațāāi silsila in Suluk Martabat Sanga, a text that is almost invariably included in Suluk Acih compilations. There are numerous manuscript witnesses of this text, several of which will be referenced in this chapter. My primary sources will be the Suluk Martabat Sanga texts in Serat Suluk Warni-warni tuwin Wirid Syattariyah (inscribed in Surakarta for K.G.P.H. Cakradiningrat by R. Panji Jayaasmara, 1864), ms. Museum Radya Pustaka [henceforth RP] 333, pp. 83-95; and in Serat Suluk Acih (inscribed in the Kraton Surakarta for Pakubuwana IX, 1867), ms. KS 502 (15 Ca), pp. 46-57.

7. In this, developments in Java appear to parallel broader historical trends across the region. See Chapter 1 in this volume by Anne Blackburn and Michael Feener.

8. K. A. Nizami, "Shațtāriyya," in Encyclopaedia of Islam, Second Edition, edited by P. Bearman, Th. Bianquis, C. E. Bosworth, E. van Donzel, and W. P. Heinrichs (Brill Online, 2012), http://referenceworks.brillonline.com/entries/encyclopaedia-of-islam-2/shattariyya -SIM_6869, accessed May 13, 2015.

9. On the spread of the Shațāriyya in Southeast Asia, see Oman Fathurahman, Tarekat Syattariyah di Minangkabau (Jakarta: Prenada Media Group, 2008), pp. 25-40; and Fakhriati, Menelusuri Tarekat Syattariyah di Aceh lewat Naskah (Jakarta: Departemen Agama RI, 2008).

10. Sèh Muhammad Gos is included in the silsila that Ronggasasmita provides in Suluk Martabat Sanga and is cited as an authority of Shațtārī discipline in the most extensive textbook of the practice and doctrine of the tarekat now extant in the Surakartan archives (R. T. Arungbinang, Bab Dérah ing Ngèlmi Tarèk Wiriding Dikir, in Serat Suluk Warni-warni tuwin Wirid Syattariyah [inscribed by R. Panji Jayaasmara for K.G.P.H. Cakradiningrat, 1864], ms. RP 333, p. 326).

11. Saiyid Athar Abbas Rizvi, A History of Sufism in India, vol. 2 (New Delhi: Munshiram Monoharial, 1983), pp. 159-160. For more on Muhammad Ghawth and his place in the formation of Shaț̣ārī Sufi traditions, see Carl Ernst's "Persecution and Circumspection in Shațtāīi Sufism," in Islamic Mysticism Contested: Thirteen Centuries of Controversies and Polemics, edited by de Frederik Jong and Bernd Radtke (Leiden: Brill, 1999), pp. 416-435; and Scott Kugle's "Heaven's Witness: The Uses and Abuses of Muḥammad Ghawth's Mystical Ascension," Journal of Islamic Studies 14.1 (January 2003): 1-36.

12. The Javanese word awak, which can be translated as "self," means "body." The word awakku (my body) translates as "I" or "me"; awakmu (your body), as "you." Sarira (self) is also glossed as "body," "person," and "you." Fortuitously, owing to its sound (that is, like the Arabic sirr), sarira also and at the same time suggests "the inmost secret (self)." The Old Javanese śarìra, again denoting body, self, and person, is from the Sanskrit śarìra, a word that in Buddhist terminology designates "a sacred relic"-in particular a relic from the mummified remains, or the cremains, of a Buddhist saint.

13. Whereas the presence of the Shațāiniyya tarekat among court circles in the Cirebon palace has received considerable scholarly attention, the prominence of the tarekat's teachings in the Surakartan court has been heretofore overlooked. On the Shațtāriyya in Cirebon, see Martin van Bruinessen's contribution to this volume and Abdul Ghoffir Muhaimin, The Islamic Traditions of Cirebon: Ibadat and Adat among Javanese Muslims (Jakarta: Ministry of Religious Affairs, 2004).

14. Without exception, the Javanese Shațāariyya silsilas that I have seen always identify 'Abd al-Ra'ūf as belonging to the family, or "the people," of Ḥamza Fanșūrī ("Sèh Ngabdul Raup, putra Ngali ingkang [a]bangsa Sèh Kamjah Pansuri”). See, for example, the silsila 
published in: Oman Fathurahman, Shattāriyah Silsilah in Aceh, Java, and the Lanao area of Mindanao (Tokyo: Research Institute for Languages and Cultures of Asia and Africa, Tokyo University of Foreign Studies, 2016). The connection between Hamza and Abd al-Ra'ūf may, however, have been less direct than this would imply; see Oman Fathurahman, Tanbih al-Masyi Menyoal Wahdatul Wujud: Kasus Abdurrauf Singkel di Aceh Abad 17 (Bandung: Mizan, 1999), p. 26. On the date of Ḥamza Fanșūrī’s death, see L. Kalus and C. Guillot, "La stèle funéraire de Hamzah Fansuri," Archipel 60 (2000): 3-24. Although Kalus and Guillot's argument for the 1527 date is convincing, it has been contested by V. I. Braginsky in his "On the Copy of Hamzah Fansuri's Epitaph Published by C. Guillot \& L. Kalus," Archipel 62 (2001): 21-33. For more on this theological conflict at the Acehnese court, see Syed Muhammad Naguib Al-Attas, Rānīri and the Wujüdiyyah of 17th Century Aceh (Singapore: MBRAS, 1966).

15. The teachings that came to be known as wahdat al-wujūd (or sometimes wujüdiyya) are rooted in the intricate and sometimes ecstatic cosmological metaphysics that was developed by the great Andalusian Sufi master Ibn 'Arabī (1165-1240). Ibn 'Arabī's metaphysics explores the multiple levels of being and potential nonbeing through which God eternally discloses Himself in His creation. The disclosure moves from God's absolute unknowable, immutable, eternal essence through real being in the creative Reality of the Light of Muhammad, to possible/relative being as God eternally impresses Himself onto nonbeing (that which-is-not), thus to make manifest His Reality in creation.

16. See 'Abd al-Ra'üf, "Autobiographical Codicil to 'Umdat al-Muhtajin,"” in Transferring a Tradition: 'Abd al-Ra' üf al-Singkili's Rendering into Malay of the Jalalayn Commentary, edited by Peter Riddell (Berkeley: University of California Centers for South and Southeast Asian Studies, 1990), pp. 222-238. In addition to his Shațtāinya silsila, the "autobiographical codicil" also provides 'Abd al-Ra'üf's Qādiriyya silsila along with a listing of the great number of other scholars and Sufis with whom he studied in the Arabian peninsula.

17. On this relationship, see Anthony H. Johns, "Friends in Grace: Ibrahim al-Kurani and 'Abd al-Ra'uf al-Singkeli," in Spectrum: Essays Presented to Sultan Takdir Alisjahbana, edited by S. Udin (Jakarta: Dian Rakyat, 1978), pp. 469-485.

18. It was Shams al-Dīn Pasai who first introduced these teachings into the Malay world; for a wonderful essay on Shams al-Dīn's major work on the martabat tujuh, see Anthony H. Johns, "Shams al-Dīn al-Sumațrā' '̄," in Essays in Arabic Literary Biography, 1350-1850, edited by Joseph E. Lowry and Devin J. Stewart (Wiesbaden: Harrassaowitz Verlag, 2009), pp. 357-371. As Shams al-Dīn's writings had been suppressed and many of his works destroyed during the purge in the early 1640s, it was 'Abd al-Ra' unf who reintroduced and disseminated the martabat tujuh teachings among the Jāwa. His teachings had no doubt gained elaboration from his Shațțāī murshid, Aḥmad al-Qushāshī. For more on textual traditions of "sevengrade" Shațtāīī Sufism in Southeast Asia, see A. H. Johns, The Gift Addressed to the Spirit of the Prophet (Canberra: Australian National University, 1965). Johns' book is a translation and commentary on an eighteenth-century Javanese poetic interpretation of the Arabic Tuhfa that was composed by Muhammad b. Faḍlillāh (d. 1620) in Gujarat. The Tuhfa was highly influential in seventeenth-century Aceh. Internal textual evidence indicates that the Javanese poetic interpretation was produced by its anonymous author on commission of the ruler of Cirebon.

19. Ngabdul Muhyi ('Abd al-Muhyī) is buried in Pamijahan (or Safarwidi, Karang) in the Tasikmalaya district of West Java. His tomb was described by D. A. Rinkes in 1910 in his article "De maqam van Sjech 'Abdoelmoehji," Tijdschrift voor Indische Taal-, Land- en Volkenkunde 52 (1910): 556-574. H. M. Froger's English translation of the article can be found in D. A. 
Rinkes, Nine Saints of Java (Kuala Lumpur: Malaysian Sociological Research Institute, 1996), pp. 1-14. The tomb remains an important shrine today and still attracts many pilgrims.

20. For more on 'Abd al-Muhyī, see Werner Kraus, "An Enigmatic Saint: Sheykh Haji Abdul Muhyi Waliyullah Pamijahan (?1640-1715?)," Indonesian Circle 65 (1995): 21-31; Tommy Christomy, Signs of the Wali: Narratives at the Sacred Sites in Pamijahan, West Java (Canberra: ANU E Press, 2008).

21. See, for example, the saint's teaching on the seven levels of the human soul in Wasiyat saking Ngabdul Mukiyi Pajang, in Serat Suluk Warni-warni (compiled and inscribed in Surakarta, 1886), ms. RP 332, pp. 116-117, and other more "magical" teachings attributed to him (and to 'Abd al-Ra'ūf) in Ėsmu: Waris saking Tuwan Sèh Ngabdul Rakub (compiled and inscribed in Surakarta, [mid-nineteenth century]), ms. RP 334, pp. 20-26.

22. Christomy, Signs of the Wali, pp. 103-104. See also R. Ng. Ronggawarsita, Serat Sarasilah: Urutipun Panjenengan Nata ing Tanah Jawi Awit Panjenengan Ratu Prabu Déwatacengkar, Medhangkamulan (compiled Surakarta, mid-nineteenth century; inscribed Surakarta, 1878), ms. Mangkunagaran [henceforth MN] 245 (Rekso Pustoko B 84), pp. $45-46$.

23. Merle C. Ricklefs, The Seen and Unseen Worlds in Java 1726-1749: History, Literature and Islam in the Court of Pakubuwana II (St. Leonards, Australia: Allen and Unwin, 1998).

24. Pakubuwana II, Serat Wulang-Dalem Sampéyan-Dalem Ingkang Sinuhun Kangjeng Susuhunan kaping II (composed Panaraga? ca. 1742 and Surakarta 1845; inscribed in the Kraton Surakarta for the future Pakubuwana X 1885/1886), ms. KS 367 (210 Na-B).

25. Pakubuwana III, Suluk Martabat Wahdat Wakidiyat (composed Surakarta, late eighteenth century), in Serat Suluk: Jaman Karaton Dalem ing Surakarta (inscribed in the Kraton Surakarta by Ng. Hawikrama, 1870), ms. KS 481 (244 Na), pp. 30-35.

26. Ronggasasmita, Suluk Martabat Sanga, stanzas 59-61, in Serat Suluk Acih, ms. KS 502 (15 Ca), p. 54.

27. Kyai T. Arungbinang, Bab Dérah ing Ngèlmi Tarèk Wiriding Dikir (composed Surakarta, early nineteenth century), in Serat Suluk Warni-warni tuwin Wirid Syattariyah (inscribed in Surakarta by R. Panji Jayaasmara for K.G.P.H. Cakradiningrat, 1864), ms. RP 333, pp. 300-471.

28. Although Arungbinang's silsila clearly marks Bagus Muhyidin as 'Abd al-Muhyȳ’s son (Bab Dérah ing Ngèlmi Tarèk Wiriding Dikir, ms. RP 333, p. 312), Tommy Christomy identifies him as 'Abd al-Muhyī's grandson (Signs of the Wali, p. 105).

29. In addition to Shațtāin metaphysical thought and practice, Abdul Gani also taught the "external knowledges" (ngèlmu lahir) that had been handed down to him from "Panembahan Kawis" ('Abd al-Muhyī). These "external knowledges" comprise formulae (ngèlmu, ismu) and prayers (donga) that are designed to enhance the adept's powers in the phenomenal worldwhen they are recited in accordance with the designated conditions. Among these knowledges are formulae to activate one's shadow self (Makdum Sarpin), to protect oneself from iron weapons, to enhance one's invulnerability (kateguhan, katimbulan), and to make oneself invisible to enemies (Arungbinang, Bab Dérah ing Ngèlmi Tarèk Wiriding Dikir, ms. RP 333, pp. 423-445). The final section of Arungbinang's Bab Dérah comprises a translation of an extended excerpt from al-Ghazālī's Bidayāt al-Hidāya (Beginning of guidance) (ms. RP 333, pp. 446-471).

30. Arungbinang, Bab Dérah, in Serat Suluk Warni-warni tuwin Wirid Syattariyah, RP 333. 
31. For Cakradiningrat's astounding web of genealogical connections with Surakartan kings and nobles along with his connection to the most celebrated of Surakartan literati, see Florida, Javanese Literature in Surakarta Manuscripts, vol. 3, p. 241.

32. The word zikir (Ar. dhikr), or "remembrance," indicates the practice of remembering God through the repetition of formulae or utterances among travelers on the mystic path.

33. Salät is the ritual practice of devotion that every Muslim is required to offer to God five times a day. Salat daim knows no time; it is perpetual. Arungbinang's suluk is Suluk saking Kitab Markun, which is to be found in Serat Suluk: Jaman Karaton Dalem ing Surakarta, ms. KS 481 (244 Na), pp. 243-258.

34. Among these suluk are Suluk Dhudha tanpa Sekar, Suluk Purwaduksina, Suluk Dumunung in Manah, Suluk Dumunung ing Toya, Suluk Dumung ing Siti, and Suluk Kitab Usul-mubin; manuscript witnesses of these suluk are found in Serat Suluk: Jaman Karaton Dalem in Surakarta, ms. KS 481 (244 Na), pp. 39-80. For other suluk attributed to Pakubuwana IV, see the listings in my Surakarta Literature in Javanese Manuscripts, vols. 1-3.

35. The princesses' mother was K. Ratu Kencana II. Later elevated to the position of R. Ayu Sekar Kedaton and then to that of K. Ratu Pembayun, R. Ayu Satariyah was the highest-ranking princess at Pakubuwana IV's court. Ki Padmasusastra and R. Ng. Wirapratana, Sejarah Ageng in Karaton Surakarta (composed Surakarta, 1900), ms. MN 670 (B 77), pp. 96-97.

36. M. Ng. Ronggasasmita and M. Ng. Tepasonta II, Suluk Martabat Sanga, in Suluk Acih Tepasantan (composed Surakarta, 1820; inscribed Surakarta, 1845), ms. MN 304 (A 90), pp. 52-53. The Teposantan manuscript is (or was), to my knowledge, the oldest surviving Suluk Acih witness. Sadly, when I last visited the Mangkunagaran in 2012, this manuscript appeared to be no longer extant in the Rekso Pustoko library.

37. Although reproduction and redaction of earlier texts without attribution were common practices among "classical" Javanese writers, this case was exceptional because of the unusual nature of Ronggasasmita's text: in his reproduction of Ronggasasmita's text, Teposanta effectively appropriated Ronggasasmita's personal autobiographical narrative (and experience) as his own.

38. The poem was first published in its entirety just a little over twenty years ago. This edition (in twelve volumes) was produced by the tireless Yogyanese scholar of Javanese literature Kamajaya (a.k.a. Partono K. Kartokusumo). Serat Centhini, vols. 1-12, edited by Kamajaya (Yogyakarta: Yayasan Centhini Yogyakarta, 1985-1991).

39. For explicit mention of these practices, see the following stanzas in the Kamajaya edition of the Centhini: canto 354, stanza 66 (Centhini, vol. 5, p. 154); canto 360, stanza 4 (6:56); canto 362, stanza 12 (6:105); canto 365, stanza 49 (6:157); canto 366, stanza 42 (6:165); canto 368, stanza 2 (6:204); canto 368, stanza 31 (6:208); canto 383, stanza 218 (7:120); canto 383, stanza 241 (7:123); canto 667, stanza 96 (11:173); canto 672, stanza 145 (12:224); canto 675, stanza 16 (12:244); canto 708, stanza 485 (12:224). On the fusion of Shațāariyya and Naqshbandiyya practices, see also Martin van Bruinessen, Tarekat Naqsyabandiyah di Indonesia: Survei Historis, Geografis dan Sosiologis (Bandung: Mizan, 1992), pp. 43-45.

40. Dipanagara, "Salasilah Kiai Mojo Tondano," Menado 15-12-1919, ms. LOr (Leiden Oriental) 8652k, cited in Carey, Power of Prophecy, p. 111.

41. The Dipanagara War (also known as the "Java War") was no small-scale rebellion. At a time when the population of the entire island of Java numbered some seven million, the war claimed at least 200,000 Javanese lives; Yogyakarta's population was reduced by half. Fifteen 
thousand colonial troops (seven thousand of whom were "Indonesians") also perished in the war. Merle C. Ricklefs, A History of Modern Indonesia since c. 1200, 3rd edition (Stanford, CA: Stanford University Press, 2001), p. 153.

42. Kyai Maja's father, Kyai Badheran (Ngabdul Arif), was installed as 'ulamā pradikan of Badheran, and later of Maja, by Pakubuwana IV. He was tasked with, among other things, praying for the welfare of the realm of Surakarta and coming to court to attend the state meetings convened by the palace's leading religious official (the Pengulu). Like his son, Kyai Badheran had great influence and a large number of pupils in the Surakartan palace. Peter Carey, Babad Dipanagara: An Account of the Outbreak of the Java War (1825-1830) (Kuala Lumpur: Malaysian Branch of the Royal Asiatic Society, 1981), pp. 261-262, n. 110.

43. On Buminata, see note 58 below.

44. Carey, Power of Prophecy, pp. 90-114.

45. Among the most copied of these was Ronggasasmita's Suluk Acih. In the mid-1880s there appears to have been a spike in the number of suluk copied in the Surakartan palace-a number of these for the crown prince who would later reign as Pakubuwana X; see my Javanese Literature in Surakarta Manuscripts, vol. 1, pp. 264-279. Several later nineteenth-century texts produced at the palace do carry faint scents of Shațāain thought. One of these is a prose treatise attributed to Pakubuwana VIII (1789-1861; r. 1858-1861), which is said to form the king's mystical manual (wirid). The text, which is largely preoccupied with locating particular Sufi concepts and terms in particular human body parts, contains a smattering of Shațtāiriyya terminology but no systematic metaphysics. This text was apparently also used by Pakubuwana X (1866-1939; r. 1893-1939) as the manual that he employed to instruct his own students (Serat Wirid-dalem Sampéyan-dalem Ingkang Sinuhun Kangjeng Susuhunan Pakubuwana ingkang kaping VIII, Bab Ngèlmu Kasampurnan [compiled Surakarta, mid-nineteenth century; inscribed at court of Pakubuwana X], ms. KS 524 [68 Sa]). In the poetic instructions that he delivered to his son, the then ten-year-old crown prince, Pakubuwana IX advises him to find teachers with knowledge of the "writing of the body" from the "four tarekat," suggesting specifically that he learn from them the knowledge of the "seven and nine grades of being." Again, the poem does not provide any metaphysical elaborations (Pakubuwana IX, Wulang Putra [Surakarta, 1976], in Piwulang-dalem Warni-warni [inscribed in the Kraton Surakarta for Pakubuwana X, 1913], ms. KS 336 [256 Ca], p. 1177).

46. Dates of composition and inscription in Javanese manuscripts, when they are provided, are almost always composed through candrasangkala (or chronograms), aphoristic phrases whose words when read backwards signify_by a logical system of associative conventions - various numerical values. For example, words associated with eyes mean "two." Words associated with fire mean "three," because guna, "fire" or "ability," also means "three" in Sanskrit. The present sangkala is Naya Suci Pandhita Aji: "Countenance" (2) "Pure" (4) "Priest" (7) "King" (1)=1742. The seventh of Rabinguawal Jé 1742 fell on the seventeenth of February 1815.

47. Suluk Acih, stanzas 10-12, ms. KS 502 (15 Ca), p. 2.

48. In another of his poetic works (no doubt drawing on his own experience), Ronggasasmita wrote of the sea voyage of another small group of Muslim pilgrims, that is, of the saints who are said to have brought Islam to Java in the fifteenth century. The narrative is vivid, telling, for example, how the pilgrims persuaded a trader to take them on his vessel, the time spent in trading ports along the way, the trader's inconstancy, and a shipwreck. Ronggasasmita, Serat Walisana, edited by Tanoyo (Surakarta: Sadubudi, 1955), pp. 5-11. 
49. The conquest of the Haramayn by the Wahhābīs in the first decade of the nineteenth century had interrupted the pilgrimage and had certainly made Mekka unconducive to Sufi practitioners. It was only in 1813 that Mekka and Medina were wrested from the Wahhābīs by Egyptian troops in the Ottoman reconquest. I am presuming, then, that Ronggasasmita and his uncle would have been dissuaded from performing the hajj during this Wahhābi interval.

50. I am grateful to both Michael Feener and Sebastian Prange for their assistance concerning the seasonal sailing schedules between Aceh and the holy lands. Pilgrims would embark from Aceh during the winter monsoon (late December to the beginning of February) to catch the westerly currents across the Indian Ocean. The voyage would take at least six weeks but could be much longer depending on the route (via the Bay of Bengal, the Maldives, or straight for Aden via Lañkā). On the return voyage, pilgrims would set off from Aden during either the long monsoon (mid-March to early May) or the short monsoon that began in mid- to late August (Michael Feener and Sebastian Prange, personal communication, January 2013).

51. Primbon (from rimbu, Kawi for "to secrete, to save away") designates a body of texts that form compilations of various forms of esoteric knowledge, with Sufi knowledge figuring prominently among them. Ronggasasmita is straightforward and, as it turns out, completely honest in the description of his project. For we find in Arungbinang's Shațtāin treatise what appears to be a witness of the very primbon text that was selectively rendered into nuanced poetry by Ronggasasmita to compose his Suluk Acih (Bab Dérah ing Ngèlmi Tarèk Wiriding Dikir, ms. RP 333, pp. 389-398).

52. Suluk Acih, stanzas 6-9, ms. KS 502 (15 Ca), pp. 1-2.

53. Yasadipura I, Babad Giyanti, 21 vols. (Batavia: Balai Poestaka, 1937-1939).

54. For a textual edition and English translation of this work, see S. Soebardi, The Book of Cabolèk (The Hague: Martinus Nijhoff, 1975).

55. Yasadipura I, Serat Ménak, 25 vols. (Batavia: Bale Pustaka, 1933-1937).

56. R. Ng. Yasadipura I, Suluk Déwaruci (composed Surakarta, 1793/1794), in Serat Suluk: Jaman Karaton-Dalem ing Surakarta, ms. KS 481 (244 Na), pp. 198-242.

57. Yasadipura I's Suluk Makmun Nurhadi Salikin is a metaphysical Sufi poem that bears within it traces of Shaț̣āī teachings. It also calls explicitly for strict adherence to the sharīa, as do many, but not all, other Shațāriyya-tinged texts of the late eighteenth- and early-nineteenth-century Surakartan palace (R. Ng.Yasadipura I, Suluk Makmun Nurhadi Salikin [composed Surakarta, late nineteenth century], in Serat Suluk: Jaman Karaton-Dalem ing Surakarta [inscribed in the Kraton Surakarta by Ng. Hawikrama, 1870], ms. KS 481 [244 Na], pp. 190197, 305-309).

58. The Kadipatèn was the governing institution within the Kraton Surakarta normally associated with the crown prince. From 1820 to 1858, there was no crown prince, however. G. P. Adipati Buminata, a younger brother of Pakubuwana IV and a patron of the YasadipuraRonggawarsita family, headed the Kadipatèn from 1820 until his death in 1834. As noted above, Buminata had been a confidant of the Shațtāriyya teacher and revolutionary Kyai Maja.

59. The first suluk is Suluk Panduking Dudunungan; the second is Suluk Burung. Both are to be found in Serat Suluk: Jaman Karaton-Dalem ing Surakarta, ms. KS 481 (244 Na), pp. 259-266. In another of his works, it is significant that Sastranagara praises 'Abd al-Muhyī, the Shațtāriyya shaykh of Karang, as the paragon of learning in contrast to the radical teachers 
who had gotten Pakubuwana IV into so much trouble during the early years of his reign (R. T. Sastranagara, Serat Wicara Keras [Kedhiri: Tan Khoen Swie, 1926], p. 9). On those troubles, the so-called Pakepung affair, see Merle C. Ricklefs, Jogyakarta under Sultan Mangkubumi, 1749-1793: A History of the Division of Java (London: Oxford University Press, 1974), pp. $285-340$.

60. The word "sharī'a" (the Way) is sometimes translated as the "sacred law of Islam." By the "sharīa folk" (ahli sarak) Ronggasasmita must be referring to the students and/or practitioners of jurisprudence whose task it is to attempt to divine God's Way in order to make their determinations of law ( $f$ iqh) as to which human actions are required, which advisable, which neutral, which inadvisable, and which forbidden.

61. The santri dul were ecstatic Sufis said to be given to excess and licentiousness. They are described in the Centhini and appear to be of the malammatiyya (blame seeker) Sufi tradition. For more on the santri dul, see Merle C. Ricklefs, Polarising Javanese Society: Islamic and Other Visions c. 1830-1930 (Singapore: NUS Press, 2007), pp. 36-38.

62. Ratib and sama are Sufi devotional practices involving music and dance, or voice and movement.

63. Ronggasasmita, Suluk Martabat Sanga, stanzas 38-51, in Serat Suluk Warni-warni tuwin Wirid Syattariyah, ms. RP 333, pp. 88-90. In the 1867 witness of the poem that was inscribed for Pakubuwana IX (ms. KS 502 [15 Ca]), the stanza numbered 43 here is missing.

64. Though "Madahab" appears to indicate a place name, it may signify here "the destination" or, perhaps, "the way out." The Arabic word madhähib (sing. madhhab), which often refers to the four "schools" of Islamic jurisprudence, can also indicate more generally the "place one goes to," "way out," or "manner followed." The place of Ronggasasmita's shaykh, then, was the disciple's most favored destination and, at the same time, the way out of his difficulties. I am grateful to Ali Hussain and Michael Feener for these suggestions.

65. The great majority of Suluk Acih compilations do, however, include the truly excessive Suluk Lebé Lonthang. On this wildly irreverent and simply wild poem, see Nancy K. Florida, "Sex Wars: Writing Gender Relations in Nineteenth-Century Java," in Fantasizing the Feminine in Indonesia, edited by L. J. Sears (Durham and London: Duke University Press, 1996), pp. 207-224.

66. On this "tradition" of writing, see S. Soebardi's The Book of Cabolèk, pp. 35-45. For a discussion of Sitijenar's "trial" and execution, see Nancy K. Florida, Writing the Past, Inscribing the Future: History as Prophecy in Colonial Java (Durham and London: Duke University Press, 1995), pp. 358-366.

67. For a more extended discussion of what Ronggasasmita might mean by diligent reading, see my Writing the Past, Inscribing the Future, pp. 1-6. I would be remiss, however, if I did not note that my recent discovery of variant renderings in variant manuscript witnesses of the stanzas that form the basis of my earlier analysis could provide somewhat different senses concerning what defines proper reading practice.

68. Suluk Martabat Sanga, stanzas 67-83, in Suluk Warni-warni, ms. RP 333, pp. 92-95.

69. Suluk Martabat Sanga, stanzas 76-77, in Suluk Warni-warni, ms. RP 333, p. 94.

70. Suluk Martabat Sanga, stanzas 77-83, in Suluk Warni-warni, ms. RP 333, pp. 94-95.

71. Suluk Martabat Sanga, stanzas 83-85, in Suluk Warni-warni, ms. RP 333, p. 95.

72. I am grateful to Ali Hussain for his suggestion that the poem appears, in the tradition of Ibn 'Arabī, to be describing the Reality of the Prophet (al-haqiqa al-muhammadiyya) as the "presence of gathering" (hadrat al-jam'), manifesting perfectly within his presence all the 
divine attributes, negative and positive, the entire cosmos in potentia (personal communication, February 5, 2013).

73. Suluk Acih, stanzas 59-71, ms. KS 502 (15 Ca), pp. 9-10.

74. Suluk Acih, stanza 73, ms. KS 502 (15 Ca), p. 10.

75. Ronggasasmita explicitly addresses the potential accusation of pantheism: "Let none of you ever dare/to call Allah the entirety of the material universe. For to call Allah such/is still to see/two beings indeed/and this is unbelief in all four schools of thought" (Suluk Acih, stanzas $22-23$, ms. KS $502[15 \mathrm{Ca}]$, p. 4). The accusation of monism is addressed in the poet's concern with embodiment, seen perhaps most clearly in his treatment of the being of the Prophet that he elaborates in Suluk Martabat Sanga.

76. Suluk Martabat Sanga, stanzas 6-10, in Suluk Warni-warni, ms. RP 333, p. 84.

77. Suluk Acih, stanza 13, ms. KS 502 (15 Ca), p. 2.

78. Ronggasasmita's translations of the Arabic terms are at times nonstandard-if not idiosyncratic. He calls the highest of the nine grades of the Prophet's being junun mukawiyah, which he identifies as the stage of the undifferentiated void (awang-awang, uwung-uwung). The poet then proceeds to translate the word junun as tata ("manifestation" or "spreading forth," but also "order"). He then splits the word mukawiyah into muka and wiyah, translating muka as rarahi (the Face) and wiyah as jagad jembar (the wide world). Suluk Martabat Sanga, stanzas 3-5, in Suluk Warni-warni, ms. RP 333, pp. 83-84.

79. Suluk Acih, stanza 55, ms. KS 502 (15 Ca), p. 8.

80. Suluk Acih, stanza 72, ms. KS 502 (15 Ca), p. 10.

81. Suluk Martabat Sanga, stanzas 83-85, in Suluk Warni-warni, ms. RP 333, p. 95.

82. On these shifting policies and their effects, see my "Writing Traditions in Colonial Java."

83. For a concise and cogent discussion of these developments, see Ricklefs, Polarising Javanese Society, pp. 74-79; see also Martin van Bruinessen's contribution to this volume.

84. This appears to have been especially true for the Qãdiriyya wa'l-Naqshbandiyya, which became widespread in the later years of the nineteenth century. This was a new order coming out of Mekka whose practices combined those of the Qãdiriyya and the Naqshbandiyya.

85. For more on the connections between the court and rural Islamic scholars, see my "Writing Traditions in Colonial Java."

86. C. Snouck Hurgronje, The Achehnese, vol. 2 (Leiden: Brill, 1906), pp. 18-20; C. Snouck Hurgronje, Mekka in the Latter Part of the 19th Century (Leiden: Brill, 1931). The Qādiriyya wa'l-Naqshbandiyya order was established in Mekka in the mid-nineteenth century, probably by the "Indonesian"-born scholar Aḥmad Khātib b. 'Abd al-Ghaffar Sambas (see Bruinessen, Tarekat Naqsyabandiyah di Indonesia, pp. 89-97).

87. Michael F. Laffan, “'A Watchful Eye': The Mekkan Plot of 1881 and Changing Dutch Perceptions of Islam in Indonesia," Archipel 63 (2002): 79-108.

88. This may have been in part a function of Dutch intervention (ibid.).

89. See Muhammad Azali Ibnu Sulaéman's advice poem that was composed in Malay and inscribed in Javanese script - apparently for Pakubuwana IX (Nasékat Manyanyi [composed and inscribed in Surakarta, 1885], ms. KS 540).

90. Ronggawarsita's treatise was published in Javanese script in 1908 with the title Serat Wirid Nyayariyosaken Wewejanganipun Wali 8 (Surakarta: Albert Rusche and Co., 1908). This publication is provided in facsimile, transliterated into Roman script, translated into 
Indonesian, and analyzed in Simuh's Mistik Islam Kejawen Raden Ngabehi Ranggawarsita: Suatu Studi Terhadap Serat Wirid Hidayat Jati (Jakarta: University of Indonesia Press, 1988).

91. Although the saints who are credited with the Islamization of Java are invariably nine in number (hence their name, the wali sanga, or "the nine saints"), which nine saints are thought to have composed this group varies considerably. In some texts there are eight (again variably named) axial saints with the ninth of their number being the princely saint (wali ngumran), that is, the king who was recognized ruler of Java at the time that they were active. See, for example, my Writing the Past, Inscribing the Future, pp. 156-157. In the Ronggawarsitan text, the eight saints who are named as the originators of the teachings that he reveals are Sunan Giri Kadhaton, Sunan Tandhes, Sunan Majagung, Sunan Bénang, Sunan Wuryapada, Sunan Kalinyamat, Sunan Gunungjati, and Sunan Kajenar (probably naming the "heretic" saint, Siti Jenar, a saint not usually included in the enumeration of the nine) (Simuh, Mistik Islam Kejawen Raden Ngabehi Ranggawarsita, p. 170).

92. Simuh, Mistik Islam Kejawen Raden Ngabehi Ranggawarsita, pp. 170-172.

93. The nine ngèlmus are in this order: (1) ngèlmu Makdum Sarpin, (2) ngèlmu Patariyah [Satariyah = Shațtāriyya], (3) ngèlmu Sirasab, (4) ngèlmu Karajèk, (5) ngèlmu Majalis, (6) ngèlmu Patakurrahman, (7) ngèlmu Supi [Sufi], (8) ngèlmu Khapi [khahfi], (9) ngèlmu Nakisbandiyah [Naqshbandiyya] (Simuh, Mistik Islam Kejawen Raden Ngabehi Ranggawarsita, p. 201). The Satariyah and Nakisbandiyah name the two dominant tarekat of early nineteenth-century Java. Majālis refers to a gathering of those on the path to perform dhikr and sama. Khahfi (spelled khapi) refers to the innermost secret or consciousness. Patahulrahman (spelled patakurrahman) is the title of the eighteenth-century Javanese adaptation of al-Anșārī's Kitāb Fath al-Rahmmān (and Raslān's commentary on it) that is transliterated, translated, and analyzed in G. W. J. Drewes' Directions for Travellers on the Mystic Path (The Hague: Martinus Nijhoff, 1977). The other three ngèlmu patah are Makdum Sarpin (conjuration of the shadow spirit associated with a person's four spiritual birth brothers: the amniotic fluid, placenta, blood of birth, and naval cord), ngèlmu sirasab (?), and ngèlmu karajèk (a knowledge apparently having to do with the science of twitches). There is a typographical error in the 1908 published edition that Simuh used as his source text, where "Satariyah" is erroneously written as "Patariyah." The earliest witness known to me of Ronggawarsita's text is one excerpted in a Kraton Surakarta manuscript that, judging from the hand, was inscribed in the late nineteenth century. This manuscript correctly writes the name of this lower instrumental knowledge as "Satariyah" (Serat Panatagama sarta Wirid [inscribed Surakarta, late nineteenth century], ms. KS 523 [13 Ca-B], p. 132).

94. Simuh, Mistik Islam Kejawen Raden Ngabehi Ranggawarsita, p. 202.

95. This originally Surakartan manuscript is now stored in the Sono Budoyo Museum in Yogyakarta (Ronggasasmita, Suluk Martabat Sanga, in Serat Suluk Warni-Warni [Suluk Acih] [inscribed Surakarta, 1872], ms. Sonobudoyo PB C.33 258 [Behrend P167]). The silsila naming the pujongga Ronggawarsita as a Shațāariyya master is to be found on page 56 verso of the manuscript. The names of his students were Ngabéhi Surakéwuh and Mas Metajaya. 


\title{
NEGOTIATING ORDER IN THE LAND OF THE DRAGON AND THE HIDDEN VALLEY OF RICE
}

\author{
Local Motives and Regional Networks \\ in the Transmission of New "Tibetan" \\ Buddhist Lineages in Bhutan and Sikkim
}

\author{
AMY HOLMES-TAGCHUNGDARPA
}

In the summer of 1953, visitors gathered in the village of Rinchenpong in the eastern Himalayan kingdom of Sikkim to bid farewell to a local luminary. These visitors, who represented a variety of ethnic and religious groups in the state and came from different classes, including aristocrats and local villagers, were unified in their devotion to Risung Rinpoche (Ri gsung rin poche), ${ }_{1}^{1}$ a Buddhist teacher who had been based in an old retreat house at the top of Rinchenpong hill for almost three decades. They mourned a beloved teacher who had traveled throughout Sikkim to perform rituals commemorating life-cycle rites and to celebrate festivals, who had been called upon as an astrologer and healer, and who was known for his talents as a teacher. Even as his health failed when he reached his eighties, Risung Rinpoche would still travel wherever he was invited, carried on a palanquin on the shoulders of faithful patrons. Among those gathered at his funeral were many of the students who had studied with him in the jungles of Rinchenpong, a site rendered powerful through its status as a cremation ground that was considered haunted and appropriate only for the most dedicated tantrikas. After several days of rituals, Risung Rinpoche's remains were interred in a distinctive stone reliquary in the jungle.

The outpouring of emotion over the loss of a meditation teacher based in a distant rural retreat center indicates the continued importance of Buddhism in Sikkimese culture at a time of striking change for the small state. Other monasteries remained important sites of cultural belonging and identity after the British departure from the subcontinent, as the local government negotiated new relationships with the new government of India and looked north to the 
new People's Republic of China with some concern. However, although Risung Rinpoche's exalted position in Sikkim appears indicative of local forms of community and identity, his biographical narrative demonstrates the transregional histories characteristic of Sikkimese Buddhism. Risung Rinpoche was originally from the neighboring kingdom of Bhutan. And, although both Sikkim and Bhutan had been anxious about Christian missionaries entering and influencing their communities, Risung Rinpoche's arrival in Sikkim had been celebrated and enthusiastically supported, just as his passing was deeply mourned.

Risung Rinpoche was one of many teachers crossing borders in the eastern Himalayas during the late nineteenth and early twentieth centuries, engaging in broader networks of trans-Himalayan Buddhist connectivity cultivated through shared histories, trade links, and the emergence of innovative new lineages. These new lineages did not involve any radical breaks with preexisting traditions or the introduction of new social identities, as Christianity did. However, they introduced new sources of authority into the Himalayan kingdoms at a time when enormous change was already under way. This change was propelled by contact with the global commercial networks facilitated by the British Empire. This chapter will explore the complex motivations behind the introduction of a specific Vajrayāna Buddhist lineage into the kingdoms of Bhutan and Sikkim around the turn of the twentieth century. In doing so, it will draw attention to the fruitfulness of analyzing the geographic extension of Buddhist lineages and Buddhist orders in relation to individual life stories and smaller-scale analyses of institution building and patronage.

The lineage of the eastern Tibetan meditation teacher Tokden Shakya Shri (Rtogs ldan Śā skya Śr̄̄, 1853-1919) presents a salient case study for understanding the processes through which lineages were and are transferred within the broader Tibetan and Himalayan Buddhist networks of practitioners and institutions. Shakya Shri spent his life on the peripheries of Tibet, in the eastern Sino-Tibetan borderlands of Kham (Khams) and later at the southeastern pilgrimage site of Tsari (Rtsa ri). He is not representative of figures usually studied as emblematic of lineage and authority in the Tibetan Buddhist world, as he was not an incarnation of a famous historical teacher (sprul sku) or the head of a vast monastic estate. These are the most commonly invoked institutional forms in Tibetan Buddhism. Instead he became known throughout the Himalayas through his personal reputation, developed through narratives that were spread by word of mouth along the Himalayan trade routes traveled by his students and later disseminated widely through the creation of a textual biography published by his children and students. ${ }^{2}$

In this chapter, I will focus on the other side of this narrative, outlining the motives of Shakya Shri's students and patrons in the adoption and dissemination of his lineage. This approach highlights the complexities involved in the acceptance of new lineage transmissions in historically Buddhist areas of the Himalayas. These new lineage transmissions introduced new practices and 
teachers into local pantheons but were rarely perceived as problematic because the modes of transmission, including textual forms and genres, ritual vocabulary, and cosmology, were seen as belonging to preexisting Buddhist traditions.

These Buddhist traditions are often labeled as "Tibetan," as they are believed to have originated historically from Tibet, to share narrative traditions with Tibetan Buddhism, and to use Classical Tibetan as the language of their recorded canons. The organization of these traditions into what we might call "orders" is, however, complex in the Tibetan cultural world. In Tibet, the concepts of the monastic order (dge 'dun) and the teaching lineage (bla brgyud, lit., "the lineage of lamas/teachers") are distinct. Monastic orders are maintained through ritual ordination ceremonies, ritual initiations (dbang) into liturgy and meditation practices, and shared behavioral expectations. In Tibet and the Himalayas, these orders are affiliated with teachers and landed institutions, such as monasteries. Teaching lineages, in contrast, are more intricate. Distinctive teaching lineages have their own texts and practices. They are often attached, but not confined, to several major traditions of Tibetan Buddhismthe Nyingma (Rnying ma), Kagyü (Bka' brgyud), Sakya (Sa skya), Geluk (Dge' lugs), and, more recently, the Jonang (Jo nang) - that have grouped together historical practitioners according to certain lineage ancestors. ${ }^{3}$ This chapter will explore the idea of lineages, distinguishing them from Himalayan monastic orders and thereby bringing into view more diverse forms of institutional formation and affiliation. Buddhism was not only based in monasteries in Tibet and the Himalayas. Other institutional forms included monastic schools, meditation retreat centers, and ritual centers or temples that included nonmonastic as well as monastic practitioners. The relationships between these forms can be understood as facilitating networks of practitioners in Buddhist exchange of knowledge, ritual, and friendship.

As well as detailing the transmission and acceptance of Buddhist lineages, I will also examine their distinctive elements and interactions in different parts of the Himalayas. Labeling local forms of Buddhism in the Himalayas as "Tibetan" does not capture the complexity of these traditions or their interrelationships on a regional level and incorrectly assumes that they all look to Tibet as their source of authority. Although acknowledging their Tibetan origins does help to differentiate them from other forms of Himalayan Buddhism, particularly the Newar form practiced in the Kathmandu Valley (which has its own distinctive history as well as some overlap with Tibetan traditions), it may veil the local agency involved in the creation of these traditions. ${ }^{4}$ Therefore, in addition to outlining the motives of local agents in the establishment of Shakya Shri's lineage, this chapter critically considers the issue of terminology in light of the complex relationship networks that have influenced the reception and dissemination of Buddhism in different parts of the Himalayas.

I review concepts of "lineage" as distinct from "order" in the TibetanHimalayan Buddhist world as a starting point for examining the issue of the 
reintroduction or revitalization of Buddhism in areas where it has previously been present. Here I consider local motives, such as participating in prophetic narratives and identity, securing patronage relationships and legitimacy, and revitalizing older traditions. I outline some of these local motives more fully through case studies of students and patrons of Shakya Shri from Bhutan and Sikkim. In particular, I look at the local conditions that allowed for Shakya Shri's lineage to be accepted in specific locations at the turn of the twentieth century as well as the shared forms of cosmology that granted Shakya Shri cultural legitimacy in these areas. This interweaving of local needs and conditions with a shared sense of history allowed new lineages such as that of Shakya Shri to function and thrive in the Himalayas and, later, on a global stage as well. This study of the mobility and localization of Shayka Shri's lineage will demonstrate the negotiability of authority within Buddhist and other communities as well as the need to consider both vernacular and cosmopolitan impulses in their expansion.

\section{DEMARCATING AUTHORITY THROUGH ORDER AND LINEAGE}

As we shall see, the terminology related to Tibetan and Himalayan orders and lineages reflects many geographic and institutional distinctions. Tibetan Buddhism is a prominent and visible Asian religion practiced on a global scale today. However, it is also commonly misrepresented as a singular, homogeneous tradition, in part owing to the visibility of the Fourteenth Dalai Lama Tenzin Gyatso (Bstan 'dzin rgya mtsho) as a representative figure of authority for the Tibetan (and wider) Buddhist community. This misunderstanding is also partly the result of the geopolitics of the nineteenth and twentieth centuries that saw the creation of a distinct state called Tibet on colonial maps, only to have it banished and subsumed within another entity called the People's Republic of China in the mid-twentieth century. Yet, historically, what was considered to be "Tibet" — or, as it is known in central Tibetan dialect, Böd (Bod) — was variously interpreted and sometimes overtly contested.

To some scholars both within and outside of the Tibetan Buddhist scholastic tradition, Böd incorporates a wide area of Inner Asia, stretching into the Himalayas in South Asia and including the geographic reaches of the Tibetan plateau. What binds these people together has also been a point of negotiation. Some scholars argue for the importance of a shared Tibeto-Burman dialect; others identify staple food practices and the centrality of barley, or tsampa (rstam pa). ${ }^{5}$ According to others, it is the practice of distinctive forms of Buddhism with shared historical narratives that distinguishes these communities as a Tibetan cultural world. Some critics argue, however, that historically Böd referenced only a small part of central Tibet until the seventeenth century, when communities throughout the plateau and the Himalayas were united by the Fifth Dalai Lama and his Mongol patrons into a new centralized state, the Galden Phodrang (Dga' ldan pho brang). ${ }^{6}$ 
All of the arguments above have their own problems, which are related to a central point: they all flatten and homogenize the diversity of cultural and political forms within this area. The last argument particularly ignores other crucial political changes in the seventeenth-century Himalayas, as new states also developed. Two of these states were the kingdoms of Bhutan and Sikkim. They had much in common in terms of their cultural narratives. The leaders that led their respective kingdoms in the seventeenth century were Tibetans who united local populations, some of whom were considered to be earlier immigrants from Tibet and others of whom were indigenous inhabitants. In both cases, these leaders used forms of Buddhism derived from the Tibetan plateau to create coherent state narratives.

They were not unique in choosing to do so. Since its inception in South Asia, Buddhism has been connected with politics, statecraft, and community identity. In the centuries following the Buddha's death, this community became an organized corporate body of monastics regulated by a code of conduct, the Vinaya. The saingha were supported by the laity, for whom there were far less distinct rules but who asserted their role within Buddhist institutions through their ritual relationships with the saigha. Both lay and monastic Buddhists followed the path of the Buddha and could reach awakening/enlightenment. In early Buddhist India, only monastics, however, participated within institutionally marked and managed intergenerational student-teacher/preceptor relationships. Over time, in diverse parts of the Southern Asian Buddhist world, Buddhist communities developed a variety of approaches to the organization and administration of monastic ordinations and transmission, and a variety of local nomenclatures used to refer to student-teacher/preceptor lineages within the monastic sphere. In some cases, Buddhist communities chose to celebrate and record nonmonastic student-teacher lineages as well, particularly following the emergence of Mahāyāna and Vajrayāna communities. ${ }^{7}$

The role of nonmonastic practitioners in the continuation of the Buddhist tradition - that is, the teachings of the Buddha and the communities that came after him - was therefore historically complex. Nonmonastic transmission lineages became distinct from monastic orders. Monks also took part in lineages organized around nonmonastics and thus held multiple affiliations, which can be understood as contributing to interacting networks. In this chapter, "lineage" will refer to practices and teachings transmitted from teacher to student, irrespective of monastic status, and will be treated as distinct from a monastic "order." Recording and investigating teaching lineages - who transmitted which elements of religious instruction to whom-provides an alternative to usual sangha-centric narratives of Buddhist history. These teaching lineages became very important in the reception of Buddhism in Tibet, as a number of crucial early translators and teachers were not members of the sangha. ${ }^{8}$ Teaching lineages can supplement — or be encompassed by - the lineage ancestors claimed by any of the four major Tibetan Buddhist traditions mentioned 
earlier (Nyingma, Kagyü, Sakya, and Geluk). In addition, teaching lineages are also sometimes identified with particular meditation traditions, especially Dzokchen (Rdzogs chen, or The Great Perfection) and Mahāmudrā (Phyag chen, or The Great Seal). Teaching lineages associated with a meditation tradition are characterized by distinctive transmission practices: teacher-disciple connections are consolidated by swearing vows of loyalty (Skt. samaya; Tib. dam tshig) and require initiation through ritual (such as Skt. abhiṣeka; Tib. dbang). Thus, teaching lineages may be — but need not be - associated by their participants with one of the major Tibetan Buddhist traditions and/or one of the central meditation traditions. They also may or may not be tied to specific landed institutions, and so understanding them in a looser sense as networks, inhabited and disseminated by individual practitioners, can be a productive way to think about their relationships. ${ }^{9}$

In the Tibetan Buddhist world, practitioners - lay and monastic - can belong to multiple teaching lineages at the same time. These lineages need not be traced to Sakyamuni Buddha. Instead, they may be traced to other buddhas, bodhisattvas, or members of the Buddhist pantheon. One striking, unique, and influential form of teaching lineage in the Tibetan Buddhist world is the terma (gter $m a)$ tradition, in which lineages are understood to derive from discovered texts or objects found by practitioners who are destined through karmic ties to identify them. These terma lineages are traced to the time of Guru Rinpoche (Skt. Padmasambhava), the Tantric sorcerer and Tibetan cultural hero who is believed to have helped introduce Buddhism to Tibet in the eighth century. Terma lineages include their own distinctive canons, featuring ritual instructions, invocation prayers to specific Tantric deities, meditation instructions, and other forms of yogic practice. The practitioners who discovered them were responsible for mastering these traditions in isolation before passing them on to students. ${ }^{10}$

Tokden Shakya Shri's lineage was made up of terma of this type. He studied with a number of renowned teachers based in eastern Tibet during his day and passed on the practices of these traditions. In addition, he had his own visionary experiences that led him to "reveal" new cycles of teachings that were held to have been hidden by the saint Guru Rinpoche during the period of the introduction of Buddhism into Tibet for discovery at a later time of need. ${ }^{11} \mathrm{He}$ mastered these cycles during years of meditation and transmitted them to his students, who included both lay Buddhists and monastics. It was this relationship of transmission that consolidated such lineages, as opposed to participation in physical institutions or shared ritual practices. The students of the founder of a terma lineage, or a "treasure revealer" as they were called, would then go on to teach these traditions and establish temples, monasteries, and other institutional homes for them. Their itineraries were often explained through Guru Rinpoche-related narratives. Shakya Shri's students often harked back to other related narratives in their activities, which were used as explanations for and justification of their promulgation of Shakya Shri's lineage in certain places. 
One idea that was particularly resonant was the narrative traditions of "Hidden Lands" (sbas yul), sacred demarcated spaces that were believed to be efficacious sites for spiritual practice and safety during times of persecution. As with his terma, Hidden Lands were also waiting to be opened by treasure revealers who had karmic connections to Guru Rinpoche and who would rediscover these sealed spaces for Buddhist practitioners at a predestined future time. ${ }^{12}$

The demarcation between the monastic order and the transmission lineage found in Tibetan Buddhism allowed for the participation of a diverse range of practitioners in areas where Tibetan-derived Buddhism spread, including these Hidden Lands. Some of the participants in these lineages were ordained monastics, but others were not. Some were ritual specialists, affiliated with monasteries; others were itinerant ritualists, supported by local communities. Still others were yogis, living for years in retreat, or regular laypeople, who had taken initiation while integrating rituals or prayers into their daily routines alongside agricultural or trade pursuits. Shakya Shri was known especially for his acceptance of a wide range of people within his teaching lineage and for his ability to teach different forms of practice to different individuals according to their needs. Though he was associated with the Drukpa Kagyü ('Brug pa bka' brgyud) tradition of Tibetan Buddhism, he held transmission lineages for both Dzokchen and Mahāmudrā meditation, and had studied with teachers from a variety of Tibetan Buddhist traditions. The social diversity and location of Shakya Shri's teacher-student community reflected these differences. Tulku Urgyen Rinpoché, a twentieth-century teacher, described the impressions that his uncle Samten Gyatso (called Uncle Tersé below), a student of Shakya Shri, had of the community. Shakya Shri's students did not live in a monastery but in a valley where his students modified the landscape in order to create living spaces near their teacher.

"Shakya Shri lived with about seven hundred disciples in Kyipuk," Uncle Tersé told me. "His disciples had dug caves all around the two surrounding slopes, while others stayed in tiny tents made of either canvas or yak-felt. Shakya Shri himself lived on a meadow in the only house around, which was a simple structure of stamped mud with one large window." . . .

Even though so many disciples had gathered around him, Shakya Shri didn't teach year round but only at particular times during summer and winter. ...

Shakya Shri told some of his disciples, "You belong to the Mahāmudrā side of the valley," while to others he said, "You belong to the Dzokchen side." And so he divided them up in two groups and gave instructions in Mahāmudrā and Dzokchen in accordance with each follower's disposition. ${ }^{13}$

Communities such as Shakya Shri's were not rare in the Tibetan Buddhist world, but their histories have been neglected. This is partly because of the 
political prominence of the megamonasteries that were spread throughout central Tibet and retained large territories that supported their monastic communities. ${ }^{14}$ These megamonasteries were not only dominant in their localities, however. They were also part of larger networks that linked them to the political centers of Lhasa and Beijing, where their patrons were. Moreover, they were self-replicating, as monastic authorities could dispatch representatives to establish satellite monasteries in the borderlands of the Tibetan world. ${ }^{15}$ In time, the traffic between the megamonasteries and their satellites was not just unidirectional, as practitioners from these borderlands also traveled to the megamonasteries to study in the centers of spiritual education of their day. These institutions were therefore very diverse, as students from throughout Inner Asia, China, and the Himalayas using a wide range of languages also traveled to the megamonasteries to study and master their curricula. Some of the talented would become part of the monastic hierarchy; others returned home or traveled elsewhere to disseminate their lineages.

However, other, smaller communities had similar patterns of geographic extension and translocal linkages. Shakya Shri had students from throughout the Himalayas who traveled to study with him. The nature of transmission in these communities is not straightforward. The majority of these students came from areas with previous Buddhist connections to Tibet. They were not new converts to Buddhist traditions. Therefore, these networks of travel and transmission cannot be seen simply as the result of missionary activity emanating from the institutional and teaching center of Shakya Shri's lineage. Instead, as Elisabeth Stutchbury, who studied the lineage of Shakya Shri in the western Himalayan region of Karzha in Lahul (in contemporary Himachal Pradesh, India), has argued, these cases indicate a more intricate process of cyclical renewal and rejuvenation for Buddhist communities. New teachers and lineages did not disturb the religious landscape of these places. Instead, their arrival and the transmission of their new lineages were seen to be part of a continuous, ongoing transmission..$^{16}$ They were developed around historical connections between certain religious centers both within Tibet and in its borderland regions, which had been facilitated through trade networks throughout the Himalayas. Although it was based outside of large landed monastic establishments, Shakya Shri's lineage was also disseminated through these networks. Its agents of transmission in Bhutan and Sikkim looked to older cultural narratives of connectivity as well as changes in the contemporary landscape to explain and support their travel and teaching.

\section{LOCAL FACTORS IN THE TRANSMISSION OF TOKDEN SHAKYA SHRI'S LINEAGE}

By the late nineteenth century, Bhutan and Sikkim had already shared a long history of interaction, conflict, and negotiation in the forging of the eastern 
Himalayan political order. However, both kingdoms were also experiencing in very different ways the enormous change brought by European interest in the Himalayas, and their negotiations with colonial modernity had strikingly different outcomes. It is this diversity of experience as well as connection through networks of practitioners and historical narratives that make Bhutan and Sikkim generative sites for the exploration of lineage and network development.

The small kingdom of Sikkim had been significantly compromised by British incursion into the eastern Himalayas. It was originally consolidated as a state in the mid-seventeenth century. The kings of the Namgyal (Rnam rgyal) dynasty were challenged by incursions into their territories by Gorkhas and Bhutanese in the eighteenth century. British interest in the Himalayas grew during this time with the desire to discover new markets as well as to discover more accessible and profitable sources for tea. ${ }^{17}$ The East India Company was also interested in finding suitable locations for sanatoria that could provide British subjects in India respite from the heat of the plains. ${ }^{18}$ They found both in Darjeeling and after a diplomatic scuffle took over the area in 1835, though nominally continued to "rent" it from the king of Sikkim. After further incidents with rulers of Nepal and Tibet, the British inserted a political officer in Sikkim in 1889, theoretically to assist with international affairs and administration. In reality, this action led to the king and his ministers losing most of their authority until the early twentieth century. ${ }^{19}$ Political officers were distinct from the British Residents in Nepal established in 1802, as in Sikkim they had more direct power. This was therefore a time of great change, during which local historical forms of political power were compromised and undermined by colonial incursion.

The kingdom of Bhutan at this time was undergoing centralization after decades of rule by the Druk Desi ('Brug sde srid), or prime ministers, who acted as regents in lieu of the Zhabdrung (Zhab drung), the incarnations of the seventeenth-century unifier of Bhutan, Ngawang Namgyal (Ngag dbang rnam rgyal, 1594-1651). After civil war in the 1870s, the leader of this movement for unification was the innovative and intelligent Ugyen Wangchuck (U rgyan dbang phyug, 1862-1926), the Pönlop (dpon slob, or minister) of Trongsa (Krong gsar). His astute leadership led him to become a crucial intermediary between the British and Tibetan governments but also ensured that Bhutan retained its sovereignty. In a move to consolidate centralized power and peace in the state, he was elected hereditary king of Bhutan in 1907. ${ }^{20}$

Although the state religion of the Zhabdrung had been part of the Drukpa Kagyü Tibetan Buddhist tradition, Ugyen Wangchuck shifted affiliations in favor of the Nyingma tradition of Tibetan Buddhism. However, he was eclectic in his generous patronage of sacred site building, artworks, and printing projects. ${ }^{21}$ From at least the 1880 s onwards, Ugyen Wangchuck became a generous supporter of Tokden Shakya Shri. This patronage relationship is demonstrated in the colophon of a text that appears in the Collected Works (Gsung 'bum) of 
Shakya Shri, which is dedicated to Ugyen Wangchuck the Trongsa Pönlop, "ruler among men.".22

Why did the Ugyen Wangchuck choose to support this meditation teacher from Kham? Evidence from the period suggests that he originally learned about Shakya Shri while traveling in Tibet working as a mediator for the British. He heard about Shakya Shri's abilities as a teacher and miracle worker, and decided to sponsor him along with a number of other lamas (religious teachers) in the eastern Tibetan region of Kham. He also sent a number of Bhutanese students to study in Kham. ${ }^{23} \mathrm{He}$ saw this sponsorship of Buddhist practice as a means to consolidate peace and happiness in Bhutan. ${ }^{24}$ The reference to peace and happiness was in response to Bhutan's unstable political situation in the nineteenth century, which Ugyen Wangchuck and his supporters were working to alleviate after a century of internal fighting. The idea of religious patronage as a tool able to unite communities in a peaceful way (thereby helping to create a strong state identity) was not new in the Buddhist world, but its use here is interesting given the political transformations under way in Bhutan.

One possible explanation for Ugyen Wangchuck's patronage of Shakya Shri could have been his desire to support an alternate transmission lineage of the Drukpa Kagyü tradition in Bhutan, distinct from that of the earlier Zhabdrung ruler incarnation, who had developed his own lineage when he originally arrived in Bhutan in the seventeenth century. This lineage had been used to unite the country and create a strong state. Before the seventeenth century, there had been a number of waves in the transmission of Buddhist orders and lineages in Bhutan, and Bhutanese Buddhism had come to incorporate eclectic forms, including the Nyingma and Kagyü traditions. ${ }^{25}$ The Zhabdrung's Drukpa Kagyü lineage was consolidated through the introduction of hegemonic forms of state ritual and religious institutions. ${ }^{26}$ Support of an alternate lineage was beneficial for Ugyen Wangchuck as he worked to unify the state at a time when he had received both local and British support to establish himself as the first king of Bhutan. The new monarchy was designed by Wangchuck to create stability and centrality, and to replace the Zhabdrung. However, although this motive may appear logical to us looking back from the present, the situation on the ground was more complicated. Transmission lineages could not be demarcated so easily. Ugyen Wangchuck continued to try to align himself with the Zhabdrung in the early twentieth century, thereby demonstrating a conciliatory and ecumenical attitude toward different Buddhist lineages. ${ }^{27}$ However, the Shakya Shri lineage was one he was especially interested, in perhaps as an alternative, to help downplay the political function the Zhabdrung had enjoyed.

Wangchuck's effort to maintain peace with the Zhabdrung was demonstrated in his patronage of an important student of the Zhabdrung named Mönlam Rabzang (Smon lam rab bzang, 1878-1945). Their close relationship is demonstrated through the story of how Mönlam Rabzang originally went to study in Kham, which also provides clues to how Ugyen Wangchuck learned 
about Shakya Shri. Ugyen Wangchuck's wife, Rinchen Pémo (Rin chen pad mo), became gravely ill in 1896. In line with tradition, Ugyen Wangchuck spared no expense to treat her, bringing in doctors and also sponsoring large rituals. However, she did not recover, and she passed away in 1900. Ugyen Wangchuck decided to give offerings in her name to all the major sacred sites and monasteries of central Tibet and so sought out a trusted and capable emissary in the person of Mönlam Rabzang.

Originally from the Tsangkha (Mtshang kha) village of Tangsibi (Stang si bi) in the Mangde (Mang sde) valley, Mönlam Rabzang was recognized at a young age as an incarnation of an acclaimed yogi. He received a broad monastic education in many of the great monastic and religious institutions of the time in Trongsar, Wangdu Phodrang (Dbang 'dus pho brang), and Punakha (Spu na kha), and with many of the great Bhutanese teachers, including the Fifth Zhabdrung Tuktrul Jikmé Chögyal (Zhabs drung thugs sprul 'jigs med chos rgyal, 1862-1904). He became most well known as an artistic savant, skilled in painting, sculpture, and other arts. These talents brought him to the attention of Ugyen Wangchuck, who commissioned a number of works from him, which led to the development of a strong relationship between the two. Therefore, it is no surprise that, at a time of personal need, Ugyen Wangchuck selected Mönlam Rabzang to travel on his behalf to Lhasa. On arriving there, Mönlam Rabzang heard tales about a famous meditation teacher in Kham named Tokden Shakya Shri and, after asking permission from Ugyen Wangchuck, traveled to study with him instead of returning to Bhutan. ${ }^{28}$ Mönlam Rabzang stayed with Shakya Shri for several years and gained a reputation in the community as a master of Mahāmudrā. Shakya Shri eventually instructed him to return to Bhutan, where Mönlam Rabzang taught and continued to carry out his artistic projects in Tashigang. ${ }^{29}$

Thus, Ugyen Wangchuck's support of Shakya Shri was not simply a political effort to disseminate lineages of Buddhism alternative to those of the Zhabdrung. These efforts also reflected his personal relationships and beliefs.

Sikkim also had a strong tradition of state Buddhism, dating from the seventeenth century. Such particular motivations and factors of local context help to explain the success of Shakya Shri's lineage in Sikkim. There, unlike the Bhutanese Zhabdrung, the kings of the hereditary Namgyal dynasty did not derive their authority directly from religious status, but instead through the age-old method of patronizing Buddhist teachers and ritual specialists. This idealized patron-lama relationship (mchod yon) was an integral part of the narrative of the founding of the Sikkimese state, which, according to Sikkimese traditions, had taken place through a Tibetan terma revealer. Lhatsün Namkha Jikmé (Lha btsun nam mkha' 'jigs med, 1597-1653) had received visions leading him to Sikkim. Sikkimese traditions recall that he, along with two other visiting Tibetans, identified the first king, Phuntsok Namgyal (Phun tshogs rnam rgyal), based on a prophecy. State traditions were sponsored by the king and 
disseminated through monastic institutions. The major monastic institution was the Pemayangtsé Monastery (Pad ma yang rtse) located in Sikkim, which had lineage ties to the Nyingma institution of Mindroling (Smin sgrol gling) in central Tibet. ${ }^{30}$

These state traditions connected to Lhatsün's terma lineage and the Tibetan Nyingma tradition had remained strong over the centuries that followed, the lamas serving as valued advisors to the kings. However, as British interest in Sikkim deepened, colonial authorities grew concerned about these relationships, particularly as the lamas were skeptical of British motivations. After a series of border skirmishes in the mid-nineteenth century, the government of India sent a political officer to oversee the affairs of the state in 1889, as mentioned earlier. The king - a minor at the time - was marginalized, as were the lamas, who were no longer given prominence in the state council. Their relationships with other monastic institutions in Tibet were also carefully monitored, and it became increasingly difficult for Pemayangtsé lamas from Sikkim to travel to Tibet for study, as they had done in the past. ${ }^{31}$

This situation opened up the opportunity for alternative lineages and institutional forms of Buddhism to flourish in Sikkim. This was evidenced particularly by the popularity of local ritual specialists and meditators. From the $1890 \mathrm{~s}$ to 1910 s, a number of these meditators traveled to study with Shakya Shri, who was then residing in Kham. ${ }^{32}$ They originally learned of Shakya Shri through word of mouth, from traders and pilgrims who had heard of him in their travels elsewhere in the Buddhist world. The technologies of colonial modernity, particularly the train, revitalized pilgrimage networks, especially within India. Many Sikkimese Buddhists visited the Buddhist center of Bodh Gaya after its rediscovery and reinvigoration through the efforts of the Ceylonese Buddhist reformer Anagarika Dharmapala (1864-1933). ${ }^{33}$ The British apparently did not see these visits to India as problematic, as they brought the Sikkimese into the centers of British imperial power and introduced them to the idea of the British as benevolent patrons of Buddhist restoration. Pelling Ani Wangdzin (Pad gling a ni dbang 'dzin, ca. 1870-1925), a female practitioner from West Sikkim, was one of these visitors and apparently took part in a state-sponsored pilgrimage to Bodh Gaya in the early 1910s. While there, she heard about Shakya Shri and decided to enrich her Tantric education by traveling to Kham and studying with him. It was only through participation in broader educational networks that she could have had this opportunity, as there were no state-sponsored nunneries or Buddhist educational institutions for women in Sikkim at the time. Some women studied with their male relatives where they could, but most were heavily involved in other agricultural and mercantile activities that occupied their time. Pelling Ani Wangdzin came from a wealthy family and had a supportive father who provided her with the financial means to pursue a religious vocation. When she returned from her time in Kham, her brothers and relatives became her patrons and built her a meditation hut above Pelling, where she taught yogic 
traditions to dozens of students who represented the many Buddhist ethnic and cultural groups present in Sikkim, including Bhutias, Lepchas, Tamang, and Gurung. ${ }^{34}$ Students of Shakya Shri in Sikkim such as Pelling Ani Wangdzin indicate how this alternative transmission lineage provided opportunities for religious education for those outside of state monastic institutions that were being monitored by British authorities.

The cases of Mönlam Rabzang in Bhutan and Pelling Ani Wangdzin in Sikkim represent the very different local situations in these kingdoms that facilitated the spread of Shakya Shri's lineage. In Bhutan, the tradition became part of broader state traditions that were in formation during the introduction of the new monarchy. Sikkim was also being fundamentally altered by interactions with colonial modernity, but a fragile royal state under pressure from British projects facilitated heterogeneity as opposed to the homogenization of state traditions.

\section{SHARED LEGACIES IN CONSTRUCTING THE BUDDHISM OF TOKDEN SHAKYA SHRI}

Although local conditions are important considerations in the motives of patrons and practitioners in introducing new lineages into an area, regional affiliations and shared sense of identity were also influential. These regional affiliations are often glossed through labeling the Buddhisms of Bhutan and Sikkim as "Tibetan-derived" or "closely-related" to Tibetan Buddhism. ${ }^{35}$ Looking more closely at the details of such affiliations, however, helps us to understand how and why local communities supported students of Shakya Shri. There are a number of factors that could strengthen or alternately undermine these affiliations, which included shared languages and print media. The shared use of Classical Tibetan for the production and dissemination of textual traditions was a key factor, ${ }^{36}$ especially in the case of this lineage, since the students of Shakya Shri were from geographically diverse areas that often spoke mutually unintelligible dialects of Tibetan or Tibetan-related languages. To overcome these differences, a shared written language was important. The Shakya Shri tradition contains a number of apocryphal stories of how students spontaneously overcame language differences and could innately understand teachers who spoke different dialects when meeting with them for the first time. Shakya Shri is said to have encountered the problem of language differences even in Kham, where the geographic extremities of the mountainous landscape had led to the development of very different dialects. Oral narratives recount his first meeting with Adzom Drukpa (A 'dzom 'brug pa, 1842-1924), one of his teachers, who later also studied with him as a student:

Upon merely meeting, guru and student felt their minds merge, becoming one. The guru Drukpa Rinpoché, being a nomad from Washül Tromtar 
[Wa shul trom tar], said in the dialect of that region, "To experience the true nature of great perfection, just rest straight out, just rest. I don't suppose there's anything else but that." Shakya Shri understood what the guru was saying to him, that there was nothing to this enlightened intent other than resting naturally, without contrivance. Adzom Drukpa transferred to Shakya Shri the enlightened intent of dharmakaya, unbiased timeless awareness as the naked unity of awareness and emptiness. Distinguishing between his ordinary mind and pure awareness, Shakya Shri attained the realization of great perfection in a quantum leap, having been directly introduced to it in the immediacy of his own true nature. ${ }^{37}$

This was an example of a "mind transmission," a narrative trope used to explain how language differences were negotiated in these communities. It seems likely that students who traveled to Shakya Shri and stayed with him for longer periods of time were responsible for facilitating discussions by serving as translators. Students were then able to absorb the teachings and put them into their own local languages to facilitate the acceptance of these teachings by local communities.

Another important factor shaping the absorption of new lineages within historically Tibetan Buddhist areas was the existence of powerful historical affiliations that were linked to historical narratives about the shared Buddhist past. Particularly, this history was focused on the very earliest periods of Buddhist interaction with the landscapes of the eastern Himalayas and was specifically remembered through stories tied to the eighth-century saint Guru Rinpoche, who was held to have been integral to the introduction of Tantric Buddhism in Tibet. He remains a popular figure revered throughout different areas of the Himalayas for his magical prowess and for performing miracles that allowed Buddhism to be introduced to specific places.

Acknowledging these narratives as forms of continuity helps to explain the enthusiastic acceptance of lineages such as that of Shakya Shri. It also helps to avoid some of the problems noted by Elisabeth Stutchbury, who cautions scholars not to rely on missionizing discourse to explain the dissemination of Buddhism. Instead, it is useful to look for connections between new lineages and older cultural narratives. ${ }^{38}$ Stutchbury found that the Shakya Shri lineage was able to enter Kardang in the western Himalayas through established Drukpa Kagyü ties as well as through narrative traditions about Guru Rinpoché and other local saints. It is tempting to interpret the entrance of new lineages into the Himalayas in the nineteenth and twentieth centuries as part of the many changes wrought by colonial modernity in the Himalayas. This was indeed part of their attraction. However, as Anne Blackburn has argued, it is important to consider how these lineages have retained markers of continuity with precolonial forms of Buddhism. They cannot simply be explained as modern, as they do not draw on "developmentalist discourse that approached social problems 
and their solution through a self-conscious reflection on [their] own era as one that required a compensatory imitation of new forms of political order, ritual and devotion, or education," approaches explicitly presented as appropriate to "modern" times. ${ }^{39}$ Instead, such lineages were closely related to and thereby naturalized by earlier disseminations of Buddhist tradition and lineage, which paved the way for and legitimated new forms. Annabella Pitkin's characterization of these shared values and narratives as an alternative form of Himalayan cosmopolitanism is also helpful here in considering the integral role of travel and how it facilitated a union of different local histories to create a shared vision of the Buddhist past for practitioners in traditions such as that of Shakya Shri. ${ }^{40}$

Narratives related to Guru Rinpoche are found throughout the Himalayan borderlands. Guru Rinpoche was a key figure for the dissemination of Tantric Buddhism in Tibet and the Himalayas. Stories tell of his subjugation and taming of local spirits and their conversion to Buddhism. These tales can be read largely as an account of the spread of Buddhism as it came into contact with and subjugated local traditions. Guru Rinpoche was also central to the terma tradition described earlier, as he had hidden original texts to be discovered at later, appropriate times by predestined individuals. Shakya Shri enjoyed a special relationship with the guru as well, through his identity as one such terma revealer. ${ }^{41}$ These links with the guru also helped created itineraries for the dissemination of Shakya Shri's lineage. Both Sikkim and Bhutan were considered part of the Hidden Land geographies. For example, all of Sikkim was traditionally known as the "Bayul Démojong" (Sbas yul 'bras mo ljongs), the Hidden Land of Rice. Its opening took place over the visits of several treasure revealers, including Lhatsün Namkha Jikmé. ${ }^{42}$ Bhutan was also believed to be home to several Hidden Lands. ${ }^{43}$ Such narratives often helped practitioners to situate themselves and their followers within a sacred landscape possessed of a deep history when they left their teacher's community and went out into the world to practice or teach.

An example of a more complex transregional connection facilitated by such a narrative is that of Risung ${ }^{44}$ Rinpoche Jikmé Kunzang Chöpel (Ri gsung rin po che 'Jigs med kun bzang chos 'phel, 187?-1953). Risung Rinpoché was a Bhutanese teacher who traveled from eastern Bhutan to study with Tokden Shakya Shri and eventually settled in West Sikkim, rather than returning to his homeland as many of his Bhutanese peers did. Risung Rinpoche was originally from the Sharchop ethnocultural community in eastern Bhutan. Little is known about how he traveled to Kham, but, after staying for a number of years in Shakya Shri's community, he decided to move to Sikkim to continue his practice of Shakya Shri's lineage. He chose Sikkim for its reputation as a Hidden Land and ended up living at Risung in the area of Rinchenpong in West Sikkim. West Sikkim had particularly powerful cultural resonance for a Bhutanese expatriate, as it was believed that Péma Lingpa (Pad ma gling pa, 1450-1521), the great Bhutanese treasure revealer, had visited and practiced in the area. 
A number of sites remain associated with Péma Lingpa in Sikkim, including the town of Pelling, which is said to be named after him, and Rinchenpong. Risung was situated in a flat area of forest that had been used as a cremation site and that was regarded as being especially efficacious for Tantric practice. Risung Rinpoche initially moved there in the early 1910s with his consort, a Sharchop woman known as Risung Sangyum, and her daughter. The local landlord, the Pönchung Thikidar, allowed him to live in a small temple that had already been built on the land, ${ }^{45}$ and Risung Rinpoche and his family became responsible for carrying out rituals for the Thikidar. Word soon spread of his ritual prowess, and he gained a number of aristocratic sponsors who invited him to different parts of Sikkim to carry out rituals related to a number of needs, including rituals for health and building consecration. Students also began to gather around him at Risung, living in simple tents and makeshift huts on the slopes below the temple. As with Pelling Ani Wangdzin's community, these students represented a number of different ethnocultural groups from the eastern Himalayas, including Bhutias, Lepchas, Tamang, Gurung, and other Bhutanese, who traveled to Sikkim to study with Risung Rinpoche. They also represented a number of institutions, including both monastic orders and teaching lineages. Some were itinerant practitioners, traveling from teacher to teacher. Others were associated with local monastic institutions and came to travel with Risung Rinpoche as a kind of apprenticeship in the rituals and meditative traditions he taught. They were varied in their level of commitment as well. Whereas some students remained at Risung for years, others passed through for a few months. As Risung Rinpoche's reputation grew, students increasingly came to stay just to gain an association with his name. They studied in a number of fields. Some of the students would travel with Risung Rinpoche, setting up their tents at patrons' houses and assisting in rituals. As Risung Rinpoche got older and his health declined, they would carry him on a type of palanquin, assisted by local patrons who would come to meet him. Other students remained in the forests at Rinchenpong, meditating during the day and practicing the dance of Chöd (Gchod) and the yoga of the winds (rtsa rlung) at night, and would later be dispatched by their teacher to undertake intensive individual retreats. In addition to the narrative memory linking Risung Rinpoche's Sikkim sites to a deep Bhutanese Buddhist past, retreat areas favored by his students were typically connected with stories about the activities of Guru Rinpoche and the early dissemination of forms of Tibetan Buddhism within Sikkim. ${ }^{46}$

What allowed this Bhutanese expatriate teacher to become so renowned in this small kingdom, which had its own distinctive Buddhist traditions? A major factor was Risung Rinpoche's association with both Dzokchen and Mahāmudrā meditation traditions. He was therefore accepted as a teacher who could bring together different networks. He was a Dzokchen master in the local Nyingma traditions as well as a teacher who could accept students with different needs and different order and lineage affiliations. His recognition of the shared history 
of Guru Rinpoche was also key to this acceptance and demonstrated the shared regional affiliations held by the Shakya Shri lineage. His students went on to hold many different roles in the historical development of Buddhism in modern Sikkim. Linguistic or cultural differences between Risung Rinpoche and his lineage, and with his Sikkimese students were not seen as detrimental. This is even more striking in its specific historical context. By the early twentieth century, the demarcation of identity, especially along national lines, was becoming increasingly influential in the Himalayas, undermining historical forms of cosmopolitanism. ${ }^{47}$ However, the history of the Shakya Shri lineage in Sikkim reveals transregional manifestations of Buddhism that survived across revised state boundaries and that flourished despite a rise in new forms of nationalist discourse.

\section{INTERPERSONAL NETWORKS AND THE COMPLEXITIES OF AFFILIATION IN THE DISSEMINATION OF SHAKYA SHRI'S LINEAGE}

The final factor that facilitated the dissemination of Shakya Shri's lineage in Bhutan and Sikkim is very simple yet often overlooked: interpersonal relationships and the broader networks that arose out of them. These interpersonal connections were often consolidated through economic and political networks. Trade routes throughout the broader Himalayas were especially influential, as they allowed for a certain amount of mobility, as did the pilgrimage traditions discussed earlier. They allowed for people with otherwise diverse forms of affiliation to meet over shared interests and to disseminate information before text traditions were consolidated. In other words, patronage relationships were a key factor in the creation of opportunities for the expansion of lineages across the Himalayas and the development of transregional education within lineages like that of Shakya Shri.

Considering interpersonal interaction as a site for the dissemination of lineage also allows for some of the more intangible elements of dissemination to be taken into account. These could include perceptions of personal charisma and magnetism that lead students to study with teachers. Such qualities are present in the Shakya Shri lineage. The Bhutanese student Tenzin Gyatso (1883-1966) provides an example. Born in Paro (Spa gro), Tenzin Gyatso began his formal study of Buddhism at a young age, when he was dispatched to live with his uncle, who was an accomplished monk. He excelled in his studies, undertaking courses in many of the great educational institutions of Bhutan. During his studies, he had the opportunity to meet with Artsa Lama (A rtsa bla ma, dates unknown), who told him about his amazing teacher the meditator from Kham: Tokden Shakya Shri. Tenzin Gyatso's hagiography states that, when Tenzin heard these tales, "the hair on his arms rose up." ${ }^{48}$ His imagination inspired, he traveled to Kham with Artsa Lama under the patronage of Ugyen Wangchuck to study with Shakya Shri. This patronage again reinforces Ugyen Wangchuck's 
personal connection to the lineage, as well as his material contributions by sending students to study with Shakya Shri. Tenzin Gyatso eventually returned to Bhutan, where he became an important teacher within the country, serving as an attendant to his uncle, who rose to become the preeminent master of Bhutan, the Jé Khenpo (Rje mkhan po), and later an important teacher and practitioner in his own right. ${ }^{49}$

Artsa Lama also visited other communities in the Himalayas, including Karzha, where he was said to have been dispatched after Shakya Shri dreamed that he had students who were living there but whom he had not yet met. ${ }^{50}$ Artsa Lama's invitation to Karzha students led to batches of students traveling to study with Shakya Shri, to the establishment of new religious institutions in the area, and, eventually, to the forging of personal relationships that contributed to the decision by one of the grandchildren of Shakya Shri to settle there in the $1950 \mathrm{~s}^{51}$

Another example of a Bhutanese student who came to study with Shakya Shri through Artsa Lama is that of Mémé Lama Sönam Zangpo (Mes mes bla ma bsod nams bzang po, 1892-1982), a key figure in the Shakya Shri lineage due to his publication of Shakya Shri's Collected Works in the 1970s (reprinted in 1998). His case is a powerful representation of Ugyen Wangchuck's personal commitment to Shakya Shri and his sponsorship of students to study in eastern Tibet. It also demonstrates the entrance of print technology into the dissemination of lineage. Sources indicate that Sönam Zangpo was related to Ugyen Wangchuck, with some even suggesting he was an illegitimate son. He was born in Kurtoe (Kur stod) into a family descended from Péma Lingpa and was a deeply religious youth, which led to his being recognized as the incarnation of two different lamas. ${ }^{52}$ When he was twelve, a number of members of his community decided to visit Shakya Shri in Kham. He was desperate to join them after hearing about Shakya Shri and feeling deeply inspired. He begged his mother, who at first refused but eventually gave in and went to see Ugyen Wangchuck to request support. Ugyen Wangchuck was moved by Sönam Zangpo's commitment to Buddhism at such a young age and offered to provide him with offerings for Shakya Shri and other provisions for the long journey to Kham. ${ }^{53}$ Sönam Zangpo then set off to join his comrades and became the youngest of the Bhutanese students sent to Kham. He remained there for many years, eventually rising to become a leader of Shakya Shri's community at Tsari. He returned to Bhutan in the 1930s, when he moved with an itinerant community of yogic practitioners between different sites associated with Guru Rinpoche and the religious history of Bhutan, staying nowhere for more than three years and developing a reputation for his service to villagers as well as to the royal family. ${ }^{54}$ His relationship with Ugyen Wangchuck as well as his mother's commitment and connections not only facilitated his own education, but also played a crucial part in the development of Shakya Shri's textual legacy far beyond the Himalayas. 
There is a famous proverb in Tibetan: "Every lama has his own religious tradition and every valley its own dialect." This saying is often used to demonstrate the diversity of language in Tibetan cultural areas of the plateau and the Himalayas. It also makes an important point about religion in these areas, as it addresses the remarkable diversity found throughout the region. This diversity manifests in a multitude of institutional, ritual, and practice lineages whose participants represent networks of multiple affiliations. It also raises important questions about the use of "Tibetan Buddhism" or even "Tibetan-derived Buddhism" as an analytic category. Acknowledging local agency and thinking about Tibetan or Himalayan Buddhisms on smaller scales is important for creating more representative histories for this area and for bringing to light the processes through which Buddhist lineages expanded and were localized in the wider Himalayan region.

Although framing histories of Himalayan Buddhism as part of the history of Tibetan Buddhism or Tibetan-derived Buddhism effaces much of the diversity, analysis from the perspective of technologies of transmission, such as lineages, orders, and networks, can help expand our gaze from the local contexts in the Himalayas to other spaces and religions. It is fruitful to examine specific small-scale technologies of transmission and the circulation of specific teaching lineages in the Himalayas as opposed to the more formal institutions of orders. This perspective includes diverse forms of practitioners beyond the monks formally associated with orders. Thinking about the different elements that frame participation in lineages across space and time, such as shared cultural narratives, interpersonal relationships, concepts of sacred space, and print technologies as well as distinctive meditative and ritual practices, helps to explain how new lineages are spread. These elements underpin affective affiliations and help to explain local-scale motives for the adoption of new lineages in areas where Buddhist traditions are already strong.

The eastern Himalayan kingdoms of Bhutan and Sikkim are both home to distinctive forms of Buddhism that share cultural forms with Tibet but have their own histories. The adoption of the lineage of Shakya Shri, embodied by the descendants of practitioners who studied in eastern Tibet with him and his disciples, is now found in a variety of religious institutional forms in different guises. Practices from this lineage are continued by scholars and members of monastic orders in large monasteries and Buddhist educational institutions in urban centers such as Thimphu and Gangtok. At the same time, lineage participants serve as patrons and supplicants at local temples throughout the countryside as wandering yogis and meditators, and even as young laypeople who adorn their cellphones and car windshields with sticker images of Shakya Shri and his students. Such varieties of connections demonstrate the ongoing adaptability of lineage in the Himalayas and its ability to meld different local and regional ideologies that hold together the orders and itineraries that create religious communities within and beyond national and regional boundaries. 


\section{NOTES}

I would like to acknowledge the generosity of all the people who have provided materials and stories used in the research for this chapter, especially Dorji Penjore; Khenpo Shedup Tenzin; Lama Thinley Namgyal; surviving members of the Risung community, particularly H. E. Dorlop Chewang Rinzin Tagchungdarpa and Mellipa; and my family in Sikkim. Anne Blackburn and Michael Feener made invaluable suggestions. I dedicate this article to the memory of my teacher Elisabeth Stutchbury, whose brilliant work on the Shakya Shri lineage in the western Himalayas continues to inspire me. I will always be grateful for her guidance, wisdom, and compassion.

1. In this chapter, Tibetan words will be transliterated according to the Tibetan and Himalayan Library system, followed by Wylie spelling in parentheses on their first appearance. In circumstances where individuals or authors are known widely by another spelling, however, their preferences will be retained.

2. This biography is Kah thog si tu chos kyi rgya mtsho, Rje bstun bla ma rdo rje 'chang chen po Śäkya shrī dznya' na'i rnam thar me tog phreng ba (originally published by Gangtok: Sherab Gyaltsen, Palace Monastery, 1990); reprinted in Shakya Shri's Collected Works, pp. 17-230. A critical study of the life of Shakya Shri and his lineage is included in Amy HolmesTagchungdarpa, The Social Life of Tibetan Biography: Textuality, Community and Authority in the Lineage of Tokden Shakya Shri (Lanham, MD: Lexington, 2014). A full translation of his biography can be found in Elio Guarisco, trans., Togden Shakya Shri: The Life and Liberation of a Tibetan Yogin (Merigar: Shang Shung Publications, 2011).

3. Tibet's indigenous religion, Bön, is also sometimes affiliated with this system of organization of lineages.

4. This flattening of Himalayan diversity is noted in Karma Phuntsho, The History of Bhutan (Noida: Random House, 2013), pp. xii-xiii, and can also be seen in general surveys related to Tibetan and Himalayan Buddhisms that often only include Tibet in the title, such as John Powers, Introduction to Tibetan Buddhism (Ithaca: Snow Lion, 2007); and Geoffrey Samuel, Introducing Tibetan Buddhism (New York: Routledge, 2012). The latter does include discussion of diverse forms of Buddhism in Bhutan, Nepal, and Ladakh as well. The terminology used to classify forms of Buddhism has recently been a topic of critical inquiry in Theravāda studies and is represented in Peter Skilling and Jason Carbine, eds., How Theravada Is Theravada? Exploring Buddhist Identities (Chiang Mai: Silkworm Books, 2012).

5. For more on these discussions, see Sam van Schaik, Tibet: A History (New Haven: Yale University Press, 2011), preface. On the discussion of tsampa and what unites Tibetan identity, see Tsering Shakya, "Whither the Tsampa Eaters?" Himal 6.5 (1993): 8-12.

6. An accessible overview of Tibetan history, in the broader sense of the word, can be found in van Schaik, Tibet: A History. A recent study that disputes centralized representations of Tibetan history is Yudru Tsomu, The Rise of Gönpo Namgyel in Kham: The Blind Warrior of Nyarong (Lanham, MD: Lexington, 2014).

7. See Ronald M. Davidson, Indian Esoteric Buddhism (New York: Columbia University Press, 2002), for more on these communities and forms of affiliation.

8. The complex process of Buddhism's entrance into Tibet is outlined in Ronald M. Davidson, Tibetan Renaissance: Tantric Buddhism in the Rebirth of Tibetan Culture (New York: Columbia University Press, 2005). 
9. For more on the historical development of the four schools and the Vinaya transmission, see Davidson, Tibetan Renaissance. Powers, Introduction to Tibetan Buddhism, and Samuel, Introducing Tibetan Buddhism, which also use the four-school system to explicate Tibetan Buddhism.

10. Accessible introductions to the terma tradition can be found in Tulku Thondup, Hidden Teachings of Tibet: An Explanation of the Terma Tradition of Tibetan Buddhism (Boston: Wisdom Publications, 1986); Janet Gyatso, Apparitions of the Self: The Secret Autobiographies of a Tibetan Visionary (Princeton: Princeton University Press, 1998).

11. Popular Tibetan historical narratives about the guru state that he visited Tibet initially in the 760s at the invitation of King Trisong Detsen (r. 755-794). However, he does not appear as a major figure in historical documents from the period. For more on his historical status, see van Schaik, Tibet: A History, pp. 34-35; and Jacob Dalton, "The Early Development of the Padmasambhava Legend in Tibet: A Study of IOL Tib J 644 and Pelliot Tibétain 307," Journal of the American Oriental Society 124.4 (2004): 759-772. For more on his development into a major cultural hero for Tibetans after the late twelfth century, see Davidson, Tibetan Renaissance, p. 213.

12. Franz-Karl Ehrhard, "The Role of 'Treasure Discoverers' and Their Search for Himalayan Sacred Lands," in Sacred Spaces and Powerful Places in Tibetan Culture: A Collection of Essays, edited by Toni Huber (Dharamsala: Library of Tibetan Works and Archives, 1999), pp. 227-239.

13. Tulku Urgyen Rinpoche, Blazing Splendor: The Memoirs of Tulku Urgyen Rinpoche, edited by Erik Pema Kunsang and Marcia Schmidt (Kathmandu: Rangjung Yeshe, 2005), pp. 129-130.

14. Melvyn C. Goldstein, "The Revival of Monastic Life in Drepung Monastery," in Buddhism in Contemporary Tibet: Religious Revival and Cultural Identity, edited by Melvyn C. Goldstein and M. T. Kapstein (Berkeley: University of California Press, 1998), p. 15. The term "megamonastery" comes from Brenton Sullivan, "The Mother of All Monasteries: Gönlung Jampa Ling and the Rise of Mega Monasteries in Northeastern Tibet" (Ph.D. diss., University of Virginia, 2013). The dissertation provides a detailed overview of these institutions.

15. Beatrice D. Miller, "The Web of Tibetan Monasticism," Journal of Asian Studies 20.2 (1961): 197-203.

16. Elisabeth Stutchbury, "The Making of Gonpa: Norbu Rinpoche from Kardang and Kunga Rinpoche from Lama Gonpa," in Tantra and Popular Religion in Tibet, edited by Geoffrey Samuel, Hamish Gregor, and Elisabeth Stutchbury (New Delhi: International Academy of Indian Culture and Aditya Prakashan, 1994), p. 188.

17. Kalzang Dorjee Bhutia, "An Evaluation of the Role of Buddhism as an Anti-Colonial Force as Depicted in the History of Sikkim" (Ph.D. diss., University of Delhi, 2014). For the impact of British incursion in the eastern Himalayas more generally, see Indrani Chatterjee, Forgotten Friends (Delhi: Oxford University Press, 2014).

18. Nandni Bhattacharya, "Leisure, Economy and Colonial Urbanism: Darjeeling, 18351930," Urban History 40.3 (2013): 442-461.

19. P. Kumar Jha, History of Sikkim, 1817-1904: An Analysis of British Policy and Activities (Calcutta: OPS Publishers, 1985).

20. Phuntsho, History of Bhutan.

21. Phuntsho outlines a number of these projects in his chapter on Ugyen Wangchuck: "The Emergence of Ugyen Wangchuck and End of Civil War," in Phuntsho, History of Bhutan. 
22. Śākya shrī et al., Grub dbang Śākya shrī dznya' na'i gsung 'bum (Kathmandu: Ven. Khenpo Shedup Tenzin and Lama Thinley Namgyal, 1998), p. 673.

23. Phuntsho, History of Bhutan, p. 495.

24. Khenpo Phuntsok Tashi, Nyi ma shar gyi phyogs las shar ba'i skar ma rnam gsum (Thimphu: Mtsho skyes rdo rje gzhi tshogs, 2013), p. 50.

25. Gyaltsen Dorji, "The Lho-Druk Tradition of Bhutan: The Arrival and Spread of Buddhism," in Bhutanese Buddhism and Its Culture, edited by S. Kumagai (Kathmandu: Vajra Books, 2014), pp. 61-72.

26. Dorji Penjore, "Rows of Auspicious Seats: The Role of Bzhugs gral phun tshogs pa'i rten 'brel Ritual in the Founding of the First Bhutanese State in the 17th Century," Journal of Bhutan Studies 24 (2011): 1-41.

27. Phuntsho, History of Bhutan, pp. 481-482.

28. Elisabeth Stutchbury, "Rediscovering Western Tibet: Gonpa, Chorten and the Continuity of Practice with a Tibetan Buddhist Community in the Indian Himalaya" (Ph.D. diss., Australian National University, 1991).

29. Gyaltsen, Dran gtam zla ba'i bdud rtsi.

30. Stutchbury, "Rediscovering Western Tibet."

31. Bhutia, "Evaluation of the Role of Buddhism."

32. Studies of these practitioners include Holmes-Tagchungdarpa, Social Life of Tibetan Biography; Annabella Pitkin, "Cosmopolitanism in the Himalayas: The Intellectual and Spiritual Journeys of Khu nu bLa ma bsTan 'dzin rgyal mtshan and His Sikkimese Teacher, Khang gsar bLa ma O rgyan bstan 'dzin Rin po che," Bulletin of Tibetology 40.2 (2004): 5-24; and Marilyn Silverstone, "Five Nyingmapa Lamas in Sikkim," Kailash 1.1 (2003):. 9-17.

33. Dharmapala's print venue, the Journal of the Mahabodhi Society, records a number of visits by Himalayan Buddhists during this period. For more on the history of Bodh Gaya, see Alan Trevithick, The Revival of Buddhist Pilgrimage at Bodh Gaya (1811-1949): Anagarika Dharmapala and the Mahabodhi Temple (Delhi: Motilal Banarsidass, 2006); Stephen Kemper, Rescued from the Nation: Anagarika Dharmapala and the Buddhist World (Chicago: University of Chicago Press, 2015). For more on Tibetan interactions with Bodh Gaya, see Toni Huber, The Holy Land Reborn: Pilgrimage and the Tibetan Reinvention of Buddhist India (Chicago: University of Chicago Press, 2008).

34. Amy Holmes-Tagchungdarpa, "Excavating the Stories of Border-Crossing Women Masters in Modern Buddhism: The Oral Biography of Pelling Ani Wangdzin and Her Family," in Understanding Buddhism through Biographies of Buddhists, edited by Todd Lewis (Oxford: Wiley-Blackwell Publishers, 2014), pp. 257-264.

35. For examples, see Powers, Introduction to Tibetan Buddhism, p. 27.

36. Holmes-Tagchungdarpa, Social Life of Tibetan Biography, and Andrew Quintman, The Yogin and the Madman: Reading the Biographical Corpus of Tibet's Great Saint Milarepa (New York: Columbia University Press, 2013), provide critical studies of the role of text in the dissemination of lineage. Ricci's study of the dissemination of an Islamic textual tradition through South and Southeast Asia, and its assimilation into local vernacular languages and cultures also demonstrates this role; see Ronit Ricci, Islam Translated: Literature, Conversion and the Arabic Cosmopolis of South and Southeast Asia (Chicago: University of Chicago Press, 2011).

37. Nyöshul Khenpo Jamyang Dorje, A Marvelous Garland of Rare Gems: Biographies of Masters of Awareness in the Dzogchen Lineage (A Spiritual History of the Teachings of 
Natural Great Perfection), trans. Richard Barron (Junction City, CA: Padma Publishing, 2005), pp. 442-443.

38. See Stutchbury, "Making of Gonpa," p. 188. See also Linda Learman, ed., Buddhist Missionaries in the Era of Globalization (Honolulu: University of Hawai'i Press, 2005), for a series of critical studies related to Buddhist missionary activities.

39. Anne Blackburn, Locations of Buddhism: Colonialism and Modernity in Sri Lanka (Chicago: University of Chicago Press, 2010), p. 212.

40. Pitkin, "Cosmopolitanism in the Himalayas."

41. This is discussed in his biography and in Holmes-Tagchungdarpa's Social Life of Tibetan Biography, chap. 4.

42. Thuthop Namgyal and Yeshe Drolma, The History of Sikkim (Gangtok: Tsuklhakhang Trust, 1908 [2003]).

43. Dorji, "Lho-Druk Tradition of Bhutan," pp. 63-65.

44. An alternate spelling of Risung is Risum (Ri gsum), literally meaning "three peaks," which refers to the three peaks of the area.

45. My thanks to the contemporary descendants of the Pönchung Tikidhar and the Gyatso family for their reminiscences of Risung Rinpoche.

46. My thanks to two of this community's few surviving members, HE Dorlop Chewang Rinzin Lama and Mellipa, for generously sharing their memories of Risung Rinpoche.

47. For more on nationalism and these changes, see Bhutia, "Evaluation on the Role of Buddhism," and Phuntsok, History of Bhutan.

48. Amy Holmes, "The Making of a Bhutanese Buddha: Preliminary Remarks on the Biography of Tenzin Gyatso, a Bhutanese Scholar-Yogi,” Journal of Bhutan Studies 17 (2007): 16.

49. Ibid.

50. Stutchbury, "Rediscovering Western Tibet."

51. See Stutchbury, "Making of Gonpa," for further discussion.

52. Tashi, Nyi ma shar gyi phyogs las shar ba'i skar ma rnam gsum, p. 42.

53. Ibid., p. 49.

54. Nyöshul, Marvelous Garland of Rare Gems. 



\section{CONTRIBUTORS}

Ismail Fajrie Alatas is assistant professor of Middle Eastern and Islamic studies at New York University. He holds a Ph.D. in anthropology and history from the University of Michigan, Ann Arbor; an M.A. in history from the National University of Singapore; and a B.A. (Hons) from the University of Melbourne, Australia. His research explores the intersections of religious authority, social formation, mobility, semiotics, and communicative practice with a focus on Islamic Law, Sufism, and the Hadramī diaspora in Indonesia (that is, those who trace their origins to the Hadramawt valley of southern Yemen). He has published articles in Comparative Studies in Society and History, Indonesia and the Malay World, Journal of Islamic Studies, Die Welt des Islams, and Studia Islamika as well as written several entries for The Encyclopedia of Islam.

Anne M. Blackburn is professor of South Asia studies and Buddhist studies in the Department of Asian Studies at Cornell University and has served as director of the Cornell University South Asia Program. She taught at the University of South Carolina before joining Cornell's faculty. She received her B.A. from Swarthmore College and M.A. and Ph.D. degrees from the University of Chicago. Blackburn studies Buddhism in Southern Asia, with a special interest in Buddhist monastic culture and Buddhist participation in networks involving Sri Lanka before and during colonial presence in the region. Her publications include Buddhist Learning and Textual Practice in Eighteenth-Century Lankan Monastic Culture (Princeton, 2001), Approaching the Dhamma: Buddhist Texts and Practices in South and Southeast Asia, coedited with Jeffrey Samuels (BPS Pariyatti Editions, 2003), and Locations of Buddhism: Colonialism and Modernity in Sri Lanka (Chicago, 2010). She is working on a new project, "Making Buddhist Kingdoms across the Indian Ocean, 1200-1500," supported in part by an ACLS Fellowship.

Martin van Bruinessen is professor emeritus of comparative studies of modern Muslim societies at Utrecht University. He is an anthropologist with a strong interest in politics, history, and philology, and has conducted extensive fieldwork in Kurdistan and Indonesia. 
Kenneth Dean is Raffles Professor of Humanities, head of the Department of Chinese Studies, and Religion and Globalisation Research Cluster leader in the Asia Research Institute of the National University of Singapore. He is the author of several books and articles on Daoism and Chinese local communal religion, religious epigraphy, and Chinese temple networks in Southeast Asia. He directed a documentary film titled Bored in Heaven about ritual sensation (2010). His most recent publication (with Hue Guan Thye) is Chinese Epigraphy in Singapore, 1819-1911 (2 vols.) (NUS Press, 2017).

R. Michael Feener is the Sultan of Oman Fellow at the Oxford Centre for Islamic Studies and Islamic Centre lecturer in the History Faculty at the University of Oxford. He was formerly leader of the Religion and Globalisation Research Cluster at the Asia Research Institute and associate professor in the Department of History at the National University of Singapore. He has also taught at Reed College and the University of California, Riverside, and held visiting professor positions and research fellowships at Harvard, Kyoto University, École des hautes études en sciences sociales (Paris), the University of Copenhagen, the Doris Duke Foundation for Islamic Art (Honolulu), and the International Institute for Asian Studies (IIAS) in Leiden, the Netherlands. He has published extensively in the fields of Islamic studies and Southeast Asian history as well as on postdisaster reconstruction, religion, and development.

Nancy K. Florida, professor of Javanese and Indonesian studies at the University of Michigan, is a historian whose work concerns Javanese and Indonesian history, historiography, and literary studies. She was director of the university's Islamic Studies Program (2010-2012). Her publications include Writing the Past, Inscribing the Future: History as Prophecy in Colonial Java (Duke, 1995) and Javanese Literature in Surakarta Manuscripts, 3 vols. (Cornell SEAP, 1993, 2000, 2012).

Amy Holmes-Tagchungdarpa is associate professor of religious studies and Asian studies at Occidental College. She received her B.A. from Victoria University, Wellington, New Zealand, and her Ph.D. from the Australian National University. She researches the cosmological and material encounters that have shaped trans-Himalayan cultures and their global connections, with a focus on Buddhist communities, language, gender, and material culture. Her first book was The Social Life of Tibetan Biography: Textuality, Community, and Authority in the Lineage of Tokden Shakya Shri (Lexington, 2014), and her current project explores printing, language, and materiality in the making of Himalayan communities.

Alexey Kirichenko is assistant professor at the Institute of Asian and African Studies, Moscow State University, Russia. He received his doctorate in history 
from Moscow State University in 2003 with a thesis focused on the study of Burmese chronicles. His primary research focus is on field and archival work in Burma dealing with monastic Buddhism, manuscript culture, Buddhist religious infrastructure, historiography, and cultural memory. His latest publications include La vie du Bouddha: Peintures murales de Haute-Birmanie (with Cristophe Munier-Gaillard and Minbu Aung Kyaing; Éditions Findakly, 2017); "Historiography: Burma," in Brill's Encyclopaedia of Buddhism, vol. 1 (Brill Academic Publishers, 2015); and "Dynamics of Monastic Mobility and Networking in Seventeenth- and Eighteenth-Century Upper Burma," in Buddhist Dynamics in Premodern and Early Modern Southeast Asia, edited by D. Christian Lammerts (Institute of Southeast Asian Studies, Singapore, 2015).

Torsten Tschacher is junior professor of Muslim culture and society in South Asia at Freie Universität Berlin, Germany. His research focuses on the history and textual traditions of Tamil-speaking Muslim societies in South India, Sri Lanka, Singapore, and Malaysia. He is currently engaged in a study of early Islamic textual cultures in Tamil between 1572 and 1842. His most recent publications include “Can 'Om' Be an Islamic Term? Translations, Encounters, and Islamic Discourse in Vernacular South Asia," South Asian History and Culture 5 (2014); "From Script to Language: The Three Identities of 'ArabicTamil," South Asian History and Culture 8 (2017); an edited volume (with Deepra Dandekar), Islam, Sufism and Everyday Politics of Belonging in South Asia (Routledge, 2016), and a monograph titled Race, Religion, and the "Indian Muslim" Predicament in Singapore (Routledge, 2018). 



\section{INDEX}

'Abd al-Ghānī of Tersana, 46, 157, $178 \mathrm{n} .29$

'Abd al-Karīm of Banten, 135, 150

'Abd al-Lațîf Jāmīe, 128

'Abdallāh al-Arzinjānī, 138

'Abdallāh b. 'Abd al-Qahhār, 131

'Abdallāh b. Aḥmad Bā Sawdān (d. 1849), 23

'Abdallāh b. 'Alawī al-Ḥaddad (d. 1720), 25, 36, 38, 40, 43

'Abdallāh b. Ḥusayn ibn Ṭāhir (d. 1855), 23, 36, 38, 40

'Abdallāh b. Sa'ad bin Sumayr (d. 1846), 23, 42n.16

'Abdallāh b. 'Umar Ibn Yaḥyā (d. 1849), 10, 20-35, 38-40, 43n.27, 47n.66, 47n.68

'Abd al-Muḥyī (ca. 1640-ca. 1715), 131, 148, 156-157, 177n.19, 178n.29, 181n.59

'Abd al-Qādir al-Jīlānī (d. 1166), 78-79, 82-83, 145, 146

'Abd al-Raḥmān b. 'Abdallah Bilfaqīh (d. 1748), 24

'Abd al-Raḥmān b. Muḥammad al-Saqqāf (d. 1416), 30

'Abd al-Raḥmān b. Sulaymān al-Ahdal (d. 1834), 23

'Abd al-Ra'ūf Singkel (d. c. 1693), 126, 127, 136, 137, 155-156, 176n.14, $177 \mathrm{n} .18$

'Abd al-Șamad Palimbānī, 44n.39, 133, 137
'Abd al-Wahhāb al-Sha'rānī (d. 1565), $44 n .39$

'Abdul Wahab Rokan, 138, 141, 150

Abū Bakr Miskīn (d. 1872), 77-78, 86, 88, 93n.11

Abū Ḥāmid al-Ghazālī (d., 1111) 36, $44 n .39$

Abū Qubays, 138, 140, 150, 151

Aceh, 26, 87, 126, 127, 131, 132, 134, $138,151,153-154,156,159-161$, $176,177,181$

$\bar{a} d \bar{a} b, 39,84,95 \mathrm{n} .26$

Aden, 161, 181

Aḥmad b. 'Umar bin Sumayț (d. 1842), 23

Aḥmad Khațīb Sambas (d. 1875), 134, 137

Aḥmad Rifā'̀̄', 134

Alaungmintaya, 53-54

'Alawī b. Saqqāf al-Saqqāf (d. 1819), 23

'Alawiyya, 20-47, 128

'Alī b. Muḥammad al-Ḥabashī (d. 1914), $43 n .19$

Amarapura, 62, 64, 72

Amarapura Nikāya, 51, 69

Amīr Ḥamza, 162

Anagarika Dharmapala (1864-1933), 19, 196, 206

Androth, 81, 87

Anuradhapura, 19, 62, 71, 72

Arakan, 65

Ariyāvaṃsa Ādiccaraṃsī (b. 1766), 55, 70,71 
Arshad al-Banjarī (d. 1812), 44n.39, 141, 149

Arungbinang, Kyai Tumenggung, 157$158,176,178,179,181$

'Arūsiyya, 78, 83

Arwi, 93, 94, 96, 97

Ash'arī of Kaliwungu, Kyai, 142, 151 'āshūra, 39

Ava (Yadanapura), 11, 54, 55, 70

'Aydarūs b. 'Umar al-Ḥabashī (d. 1896), 24-25

Aydarūsiyya, 127

Ayutthaya, 11, 51-61, 70, 72

Bā 'Alawīi 21, 23-28, 28-36, 38-41, $42-43,46,47,128$,

Babussalam, 139-142, 150

Badon-min (r. 1782-1819), 61-64, 72

Bagan, 54, 55, 67, 70, 71

Bangkalan, 32, 34

Banten, 46, 126, 128, 131, 132, 134137, 145, 146, 149, 150, 156

Baoshanting (Precious Mountain Pavilion), 105, 106

Baosheng Dadi (The Great Emperor Who Protects Life), 104-105

Batak, 139

Batavia, 134

bay'a, 38, 77, 129, 133, 134, 143

Bengal, 61

Bhutan, 12, 13, 185, 186, 188, 189, 192-195, 197, 199-207

Borneo, 31, 114, 133, 134, 141

Bosch, Johannes van den (d. 1844), 27

Buddhist monastic community. See sangha

Bugis, 149

Burhān al-Dīn in Ulakan, 131

Burhānpūrī, Faḍl Allāh (d. 1620), 84, 96n.39, 132, 148

Burma, 16-19, 49-56, 58-69, 71-74, 123

Cai Shizhang, 105

Cantonese, 103

Celebes. See Sulawesi
Cetiya, 62, 71

Cetyavamsa, 54, 70

Cheang Hong Lim (Zhang Fanglin, 1842-1892), 115, 116, 119

Chen Yuan (fl. 804), 107

China, 62, 63, 65, 68, 73, 74, 99, 101$106,111-113,116-121,124,147$, $186,188,192$

Chishtiyya, 75-76, 83, 90, 130

Christian monasticism, 3

Ciji (Merciful Salvation), 117

Cirebon, 28, 131, 134, 146, 148, 151, 176,177

Cixi (Empress Dowager, 1861-1908), 11

Classical Chinese, 2

Classical Tibetan, 2, 187-188, 197

Cold War, 9

colonial modernity, 193, 196-199

Coromandel, 65, 94

dabus, 39, 46n.65

Dalem Bojong, 157

Darqāwiyya, 78, 84, 86, 93n.12

darsiana, 16

Demak, 166

dérah, 157-158

Déwaruci, 162, 181

dhikr, 6, 42, 43, 83-85, 95n.26, 121, 130, 133-136, 138-140, 144, 149, $155,156-158,168,179,184$

Dipanagara, 21, 27, 31, 44n.40, 45n.54, 159-160, 172, 175, 179

Division of incense network, 102

Dragon Pool Monastery, 104

Drukpa Kagyü, 191, 193, 194, 198

$d u^{\prime} \bar{a}^{\prime}, 128,144$

dual sovereignty, 65

Dutch colonialism, 153, 159, 172, 175

Dzokchen, 190, 191, 200

East Asia, 50

East India Company, 45n.54, 51, 57, 193

Egypt, 27, 38, 44, 86-87, 90, 129, 146-147, 181 
Fagushan (Dharma Drum Mountain), 117

fanā', 155

Fanșūrī, Hamza (d. 1527), 126-127, 145-146, 156, 176-177

Fāsiyya, 77-78, 83-84, 86, 88, 90-91, 93n.11, 94n.12

fatwa, 37, 39, 94n.20

Fenling (division of god statue network), 102

fiqh, 36, 94, 126, 133, 137, 143, 171, 182 n. 60

Foguangshan (Buddha Light Mountain), 117

Fraternity, 4, 16, 26, 50

Frojet, François, 105

Fujian, 100-104, 110-113, 115, 116, $121-123$

Geluk, 187, 190

Gowa, 131, 149

Great Opium Syndicate (Singapore), 115

Guangfu gumiao (Guang[dong] and Fu[jian] Temple, Penang), 110111,115

Guanghuasi (Monastery of Broad Transformations), 117

Guangze zunwang (Reverent King of Broad Compassion), 109

Guanyin, 101, 106

Guishansi (Turtle Mountain Monastery), 117, 123

Gujarat, 80, 93n.6

Guru Rinpoche, 185, 186, 190-191, 197-202, 205, 207

Gushan Yongquansi (Drum Mountain Monastery, Fuzhou), 110

hadith, 4, 32, 91, 127, 137, 171, 174

Hadrramawt, 20-26, 28, 30, 31, 34-35, $38,40-42,46,47,87,209$

Hainan, 103

hajj, 77, 140, 151, 156, 160-162, 173, 181

Hakka, 103
Ḥasan b. Șāliḥ al-Baḥr al-Jufrī (d. 1856), 23

Heng San Ting (Eternal Mountain Pavilion), 106-107

Hidden Lands, 191, 199

higher ordination. See Upasampadā

Hijāz, 29, 40, 45, 154, 156, 173

Himalayas, 8, 13, 22, 185-207

Hokkien, 103, 105, 106, 109, 115, 116, 120

Hong San See (Phoenix Mountain Monastery, also known as Fengshansi), 109

Hoon Choon (Buddhist master, 19071990) 109

Hsinbyumyashin (r. 1551-1581), 60, 61

Hsinbyushin (r. 1763-1776), 53-55, 60,71

huiguan, 103, 104

Huiguan (native-place associations), 103

Ibn Aḥmad Bā Faqīh (d. 1872), 34

Ibn Taymiyya (d. 328), 126

Ibrāhīm al-Kūrānī (1614-1690), 80, 127-128, 130-132, 137, 148n.28, 151n. $51,156,177$ n. 17

ijāza, 24-25, 98, 129-131, 137, 138, 140, 142, 143, 145

Imām al-'Arūs. See Māppillai Leppai (1816-1898)

India, 6-8, 11-13, 15-19, 21, 26, 29, $42,43,45,51,56,58,61,62,67$, $72,75-78,80-83,85-87,90,114$, $120,122,129,130,147,154,161$, 176, 181, 185-186, 189, 192, 193, 196, 204-206, 209, 211

Indian Ocean, 58, 65, 68, 73-74, 91

Indonesia, 112, 125-145, 154

Indonesian Archipelago, 22, 26-31, 35, $38,40,99$

Indo-Tibetan highlands, 12, 185-207

insān kāmil, 155, 168-169

Islamic jurisprudence. See figh

Ismā'̄̄l Minangkabawī̄ 138, 150

Isnād, 136-137, 143, 145, 150 
Java, 80, 127, 131, 138, 142-143, 153-184

Javanese: ethnic group, 131, 138, 142, 143; language and culture, 136, $142,143,148,151,152-184$

Java War, 21, 27, 31, 44n.40, 45n.54, $153,159,160,172,175,179$ n.41

Jāwa, 136-138, 143, 144, 150

Jilesi (Monastery of Extreme Joy), 104, $110-112,122,123$

Jinmen, 106

Jonang, 187

Kagyü, 187, 190, 191, 193, 194, 198

kalām, 171

Kandy, 50-52, 56-62, 64, 68-70, 72, 91

Kannur, 78

karāmāt, 126

Kartasura, 157

Kayalpattinam, 77-79, 82, 88, 94n.16

Kāzarūniyya, 147

Kerala. See Malabar

khalīfa, 127, 129, 131-135, 137-141, 143-147, 150

khalwa, 140, 150-151

Khalwatiyya, 35, 128-129, 133-135, 146-147, 149, 151

Khalwatiyya-Sammān, 128, 134

Khalwatiyya Yūsuf, 128

Khams, 186, 194-197, 199, 201, 202, 204

khānaqā, 128-129, 146-147

Khatmiyya, 149

khirqā , 25, 26, 39-40, 42

Kilakkarai, 78, 94n.17

Kīlakkarai Taykā Ṣāhib (17781850/51), 78, 85

Kim Lam Temple (Golden Lotus Temple), 107

Kīrti Śrī Rājasiṃha (r. 1747-1782), 51, $57,60,68$

Kolkata, 62

Konbaung, 53, 63, 64, 67, 71

Kotțēe, 60

Kozhikode, 93n.10

kraton, 153-184
Kriyan Ki Buyut, 142

Kubrawiyya, 128, 129, 146

Kwan Im Thong (Guanyin Hall), 117

kyai, 143

Kyai Maja (d. 1849), 159-160, 172, 173, 180n.42, 181n.58

Kyai Mas, 157

Kyai Mufid of Kedhung Lo Roma, 157

Kyai Talabudinu of Banyumas, 157

Kyai Tumenggung Arungbinang. See Arungbinang

Kyethtungin Hsayadaw (1693-1775), 54,70

Lakshadweep Islands, 81, 87

Langkat, 139, 140, 151

Laṅkā, 7, 48-63, 65-73, 75-83, 85-92, 181, 207, 209

Leppai Nayināā, 88, 97n.51

Lim Boon Keng (1869-1957), 116

Lineage, viii, 2-16, 21-23, 25, 30, 31, $38,48-52,55-56,58,59,61,68$, 69, 76-81, 83-92, 121, 123, 145, 151, 154, 156-157, 159, 164, 165, 171, 173-174, 186-204, 206

Liu Wangye, 107

madhhab (pl. madhāhib), 4, 182n.64

Madras, 77, 93-96, 114

Madras Presidency, 82

Madura, 32, 34, 45n.54, 47n.68, 134

Maghreb, 78

Mahabharata, 162

Mahāmudrā, 190, 191, 195, 200

Mahāvamsa, 51, 59, 60, 62

Mahāyāna, 99

Maḥmūd b. Muhammad Leppai, 84

Makassar, 127-128, 149, 151

Malabar, 78, 79, 80, 87, 91, 93, 94

Malacca, 105

Malay: ethnic group 56-57, 134, 138, 139; language, 126, 127, 132, 133, $136,137,138,144,148,156$

Malaya, 139, 104, 135, 141

Malayalam, 87

Maldives, 81, 181 
manāqib, 20, 42, 45, 82, 96

Māppiḷ!ai Leppai (1816-1898), 78-79, $82-83,85,88,94 \mathrm{n} .14$

Martaban, 53

martabat tujuh, 131, 148, 155-158, $177 \mathrm{n} .18$

Mawlānā Khālid, 140, 141

Mazu (Goddess of the Sea), 106

Medina, 127, 128, 130, 131, 133, 141$144,156,181$

Mekka, 20, 23, 27, 39, 44, 45, 77-78, 86-87, 90, 126-128, 130, 132, 134-138, 140-146, 150-152, 160, $161,173,181 \mathrm{n} .49,183$

Mémé Lama Sönam Zangpo (18921982), 202

Miaolian (1824-1907), 110-111

miaozhu, 100

Min Letwe Nawyahta U Ne (17231791), 61, 62

Minnan, 100, 103, 118

Mohamed Macan Markar (d. 1952), 77, 93n.11

Mönlam Rabzang (1878-1945), 201-202

Monywe, 52, 55, 67, 70, 73

Mottama. See Martaban

Muhammad (Prophet), 82-83, 87, 154, 157, 163, 165, 168-169, 172, $182 \mathrm{n} .72$

Muhammad b. 'Abd al-Karīm al-Sammān (d. 1775), 133, 134

Muḥammad b. 'Alī Bā 'Alawī al-Faqị̣ al-Muqaddam (d. 1255), 41n.4

Muḥammad Bukhārī Tañnạ̣ (d. 1792/93), 78, 88

Muhammad Ghawth of Gwalior (d. 1563), 80, 156, 176n.10

Muhammad Salim of Madahab, 157, 165

Mu'īn al-Dīn al-Chishtī (d. 1236), 82

mukhtașar, 29, 37

Mun Ko, 54, 55, 70, 71

munājāt, 139

murid, 77, 140

murshid, 77, 130, 174
Nabadwip, 61, 62, 72

Nafīs al-Banjarī, 148, 149

Nagore, 80-82, 95n.23

Ñāṇābhivaṃsa (1751-1832), 61-64, 72,73

Naqshbandiyya, 76, 94n.20, 125, 138 $140,141,143,144,150,158,159$, 173,174

Naqshbandiyya Khālidiyya, 125, 138141, 143-144

nation-state, $92 \mathrm{n} .2,186-187$

al-Nawawī (d. 1278), 24, 36

Nawawī Banten, 137

networked orders, 77-78, 80-81, 83-92, 102

Ngasingu-min (r. 1776-1782), 70

ngèlmu, 132, 162, 167, 174, 178n.29, $184 \mathrm{n} .93$

nikai. See nikāya

nikāya, 50-52, 59, 66, 67-69

Nūḥ b. 'Abd al-Qādir of Kayalpattinam (1830/31-1905/06), 82, 86-88

Nūr al-Dīn al-Rānīrī (d. 1658), 126127, 130, 132, 146, 156

Nyingma, 187

Ottoman Empire, 78, 87, 90, 141

Pakubuwana II (r. Kartasura and Surakarta, 1726-1749), 44n.40, 156-157

Pakubuwana III (r. 1749-1788), 157

Pakubuwana IV (r. 1788-1820), 158-159

Pakunataningrat, 31,34

Palembang, 27, 29, 102, 132-134, 138

Pāli, 48, 54, 60-63, 65, 67, 69, 70, 72

Pali imaginaire, 11

Pamijahan, 131, 148, 177n.19

paramparā, $16 \mathrm{n} .14$

Pariaman, 131

Patani, 134

Pelling Ani Wangdzin (1870-1925), 196-197

Péma Lingpa (1450-1521), 199-200

Penang, 110-111, 114 
perdikan, 142

pesantren, 28, 31, 35, 40, 134, 136, 142-143, 150, 151

Pickering, William (1840-1907), 114

Po Chiak Keng Tan Si Chong Su (Temple for the Protection of the Pure, Main Chen surname Lineage Hall), 99

Pontianak, 31

Primbon, 162, 181n.51

print technology, 82-83, 86, 89, 202

Pudu (Hungry Ghosts Universal Deliverance) Association, 106, 109

putihan, 125, 141-144, 151

$q \bar{a} d \bar{l} \bar{l}, 126,156$

Qādiriyya, 76-81, 83-91, 92n.2, $97 \mathrm{n} .55,127,129,133,145$

Qādiriyya wa'l-Naqshbandiyya, 125, 134-135, 137, 141, 142, 143, 144, 149,173

Qianlong emperor (r. 1736-1796), 63, 72

Qing dynasty (1644-1911), 62-65, 67, 72-73, 118

Qingming (Tomb-Sweeping Festival), 106-107

Qingyunting (Temple of the Blue Clouds), 99, 105-106

Qingzhen Yuanjun (Primordial Lord of Pure Perfection), 115

Quanzhou, 104, 107

Qur'ān, 156, 171, 174

al-Qushāshī, Ahmad (1583-1661), 80, 84, 96n.39, 127, 130, 131, 134, $150,156,177 \mathrm{n} .18$

$q u t ̣, 157$

rābița bi'l-shaykh, 140

Rājadhi Rājasiṃha (r. 1782-1798), 64

Ramayana, 162

rātib, 83, 129, 130, 132, 133, 134, 148, 149, 164

Ratu Pakubuwana (d. 1732), 157

Reid, Anthony, 99
Religious ecology, 111

Rifā'iyya, 76-77, 80-82, 87-91, 93n.6, $126-127,129$

Risung Rimpoche (187?-1953), 185, 186, 199-201

Ronggasasmita, Mas Ng., 153-184

Ronggawarsita, R. Ng. (1802-1873), $153,160,174-175,175$ n. 2

Șadaqatullāh b. Sulaymān of Kayalpattinam (1632-1703), 79-80, 88, 96n.39, 97n.51

Safīnāt al-najāh, 29, 42n.16, 46n.64

Sagaing, 53-55, 59, 61

Sālim b. 'Abdallāh bin Sumayr (d. 1853), 29-30, 42n.16, 46n.64

Sām Shihāb al-Dīn (1634/35-1709), 80, $82,95 \mathrm{n} .30$

samä, 24, 164, 182n.62, 184n.93

Samantacakkhudīpanī, 55, 70n.33

Sammāniyya, 35, 130-131, 133-134, $135,137,141,144,148-149$

Sanbaoshan, 105

sangha, 48-49, 52, 57, 63, 66, 71, 110-112, 189

santri, 142

santri dul, 165, 182n.61

al-Sanūsī (d. 1490), 38, 40

Sāralanika (b. ca. 1730), 11, 49-50, $52-64,66,67,69-72$

sāsana, 54, 60, 62-64, 66, 68

Sayyid Muḥammad b. Aḥmad. See Māppiḷlai Leppai (1816-1898)

Sayyid 'Uthmān (d. 1914), 47n.66

secret society. See Triad

Sèh Sitijenar, 166, 182n.66

Shādhiliyya, 75-78, 81, 83-84, 86-90, $128,130,146$

Shāfi'ì legal school, 25

Shāh al-Hamīd of Nagore, 80, 82

Shakya Shri, 185-207

Shams al-Dīn Pasai / al-Sumațānī (d. 1630), 126-127, 156, 177n.18

Shantang (Halls of Merit), 118

sharī'a, 126, 134, 143, 157, 163, 165, $166,168,171,182$ n. 60 
Shattāāiyya, 35, 80, 89, 96n.39, 127, $128,130,131,135,142,148,151$, 153-184

Shinnāwī, Aḥmad (d. 1619), 128, 130

Shuanglinsi (Double Grove Monastery), 101, 104, 112-113

Siam, 50-53, 56, 58-60, 68-72

Șiddīq b. 'Umar Khān, 133

Si Hoo Key (Xue Foji, 1783-1874), 106

Sikkim, 185-207

Silk Road, 11 silsila, 24, 26, 40, 76-79, 81, 93n.9, 94n.13, 95n.26, 129, 130, 131, 136, $137,143,145,146,151,154,157$, $164-165,171,174$

Singapore, 29-31, 106-110

Sinhalese, 49-51, 56-60, 62, 67-69, 74

Siyam Nikāya, 50-52, 59, 66-68, 85, 91-92

Snouck Hurgronje, 131, 138

Song Dafeng (1039?-1127?), 119

South China Sea, 1, 8

Southern Asia, 21, 22, 26, 40, 49-53, $58,62-67,72,74,80,96$ n. 36

Sri Lanka, 48-63, 65-73, 78, 92n.2

Straits of Malacca, 161

Straits Settlements, 104-112

stūpa, 54, 60, 64

Suez Canal, 173

Sufi orders. See tarīqa

Suhrawardiyya, 129

Sulawesi, 128, 134

Sulaymān al-Qirīmīe 138

Sulaymān al-Zuhdīe 138, 140-141, 150-151

Sullam al-tawfīq, 8, 46n.64

Sultan 'Abd al-Qādir b. 'Abd al-Raḥmān Tjakraadiningrat II of Bangkalan (d. 1847), 32, 34, 46n. 54

Sultan Agung (r. Mataram, 16131645), 174

Sultan Iskandar Muda (r. 1607-1636), 156

Sultan Musa of Langkat, 139, 140, 151
Sultan Uthmān b. 'Abd al-Raḥmān al-Qadrī of Pontianak, 31

suluk (poem), 153-154, 157-159, 162-175

sulūk (ritual practice), 138, 139, 140

Sumatra, 127, 130, 138, 139, 153, 156

Sumenep, 32, 34

Sunan Gunung Jati, 128, 146, 184n.91

Surakarta, 153-184

Syria, 86, 97-98n.56, 146-147

Tadhkira, 35, 38

tafsìr, 156

Ṭāhir b. Ḥusayn ibn Ṭāhir (d. 1814), 23,25

Tai, 53, 64, 66, 67, 74

tä' ifa, 129, 147

Taixu (1890-1947), 116

Tamil (language), 76, 78-79, 82-85, 87, 90-91, 95n.26, 97n.50

Tamil Nadu, 11, 79-80, 83, 86-88, 91-92

Tan Kah Kee (Chen Jiageng, 18741961), 116

taíkal, 87, 90, 97n.50

tan்ial (Malayalam). See tankkal

tarekat. See țarīqa

țariqa (pl. turuq), 21-25, 29-31, 39-40, 75-77, 79-81, 83-84,

86, 88-90, 92-93n.6, 93n.9,

94-95n.21, 125-152, 153-160, 172-175

Tavoy (Dawe), 53-55, 59

tekke, 129

temple networks, 102

Tenasserim, 11, 50, 52-58, 70

Tenzin Gyatso (1883-1966), 201-202

Teochew, 103

terma , 190-191, 195-196, 99, 205n.10

Thai, 50, 51, 59, 67, 68

Theravāda, 65, 68, 69, 74

Tian Hou (Empress of Heaven), 105

Tianfugong (Thian Hock Keng

Temple), 106, 109

Tianshifu (Celestial Masters

Headquarters), 101 
Tibet, 185-207

Tibetan Buddhism, 185-207

Tījāniyya, 142-143

tipițaka, 48, 62

Togden Shakya Shri (1853-1919), 185-207

Triad, 103, 113-115

Tripitaka (Chinese Buddhist Canon), $112,123 n .32$

tsampa, 188

Ugyen Wangchuck (1862-1926), $193-$ 195, 202

'Umar b. 'Abd al-Karīm b. 'Abd al-Rasūl al-Atțār (d. 1833), 23

'Umar b. 'Alī al-Junayd (d. 1852), 29-31

'Umar Bā Shaybān, 127

'Umar b. Saqqāf al-Saqqāf (d. 1801), 23

'Umar Walī (1748-1801), 78, 85, 88

upajjhāya, 5

upasampadā, 48-53, 55-59, 62-63, 66-67, 69, 74

Upper Burma, 50, 52-55, 58-62, $64-65,67,70,74$

'uqda, 24, 26, 38-40

Vajrayāna, 189

Välavița Saraṇaṃkara, 51, 68

van den Berg, L. W. C., 45n.53, 47n.68

vinaya $, 48,56,60,62,189$

waḥdat al-wujūd, 132, 148, 156, 169, $177 \mathrm{n} .15$

Wahhabis, 140

walī 126, 157-184 wali sanga, 184n.91

waqf, 31

wilāya, 76

wird, 83-84, 129, 130, 144, 157, 174, 180 n. 45

Wutai, 63, 64, 73

Xiantianjiao (Way of Prior Heaven), 117

Yangon, 52, 62, 69

Yasadipura I (d. 1803), 153, 162, 167

Yasadipura II (d. 1844), 153, 159, 162

Yāsīn Padang (d. 1990), 127, 150

Yemen, 17n.17, 23-24, 41n.4, 87, 128

Yunnan, 123n.32, 63-66, 73n.73, $74 \mathrm{n} .77$

Yūsuf Makassar (d. 1699), 126, 127, $130,131,136,137,146,149$

Zabīd, 17, 23

zāwiya, 75, 86-87, 90, 129, 130, 132, $133,137,138,146$

Zeng Qilu (1643-1718), 105

Zhabdrung, 193-195

Zhang Bishi (1840-1916) and other patrons of Jilesi, 111

Zhangzhou, 104

Zheng Chenggong (1624-1662), 104

Zheng He (1371-1433), 102

Zheng Jing (1642-1681), 104

Zhen Jing (Abbot), 117

Zhongyuan pudu. See Pudu

zikir. See dhikr

ziyāra, 126

Zomia, 65 

